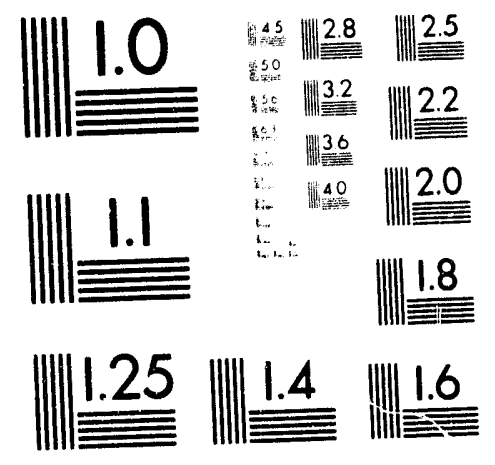



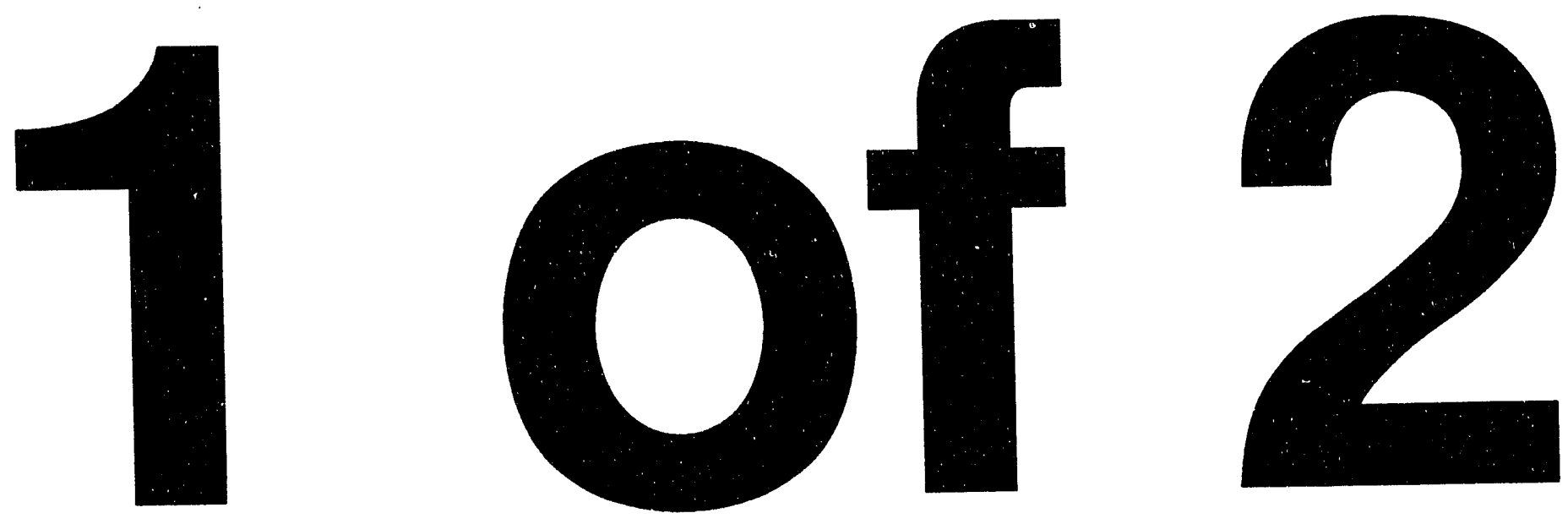


\section{Groundwater Impact Assessment for the 216-U-17 Crib, 200 West Area}

S. P. Reidel

V. G. Johnson

N. W. Kline

Date Published

June 1993

Prepared for the U.S. Department of Energy Office of Environmental Restoration and Waste Management

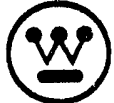

\section{Westinghouse}

P.O. Box 1970

Hanford Company Richland. Washington 99352

Hanford Operations and Engineering Contractor for the

U.S. Dedartment of Energy under Contract DE-AC 06-87RL10930 


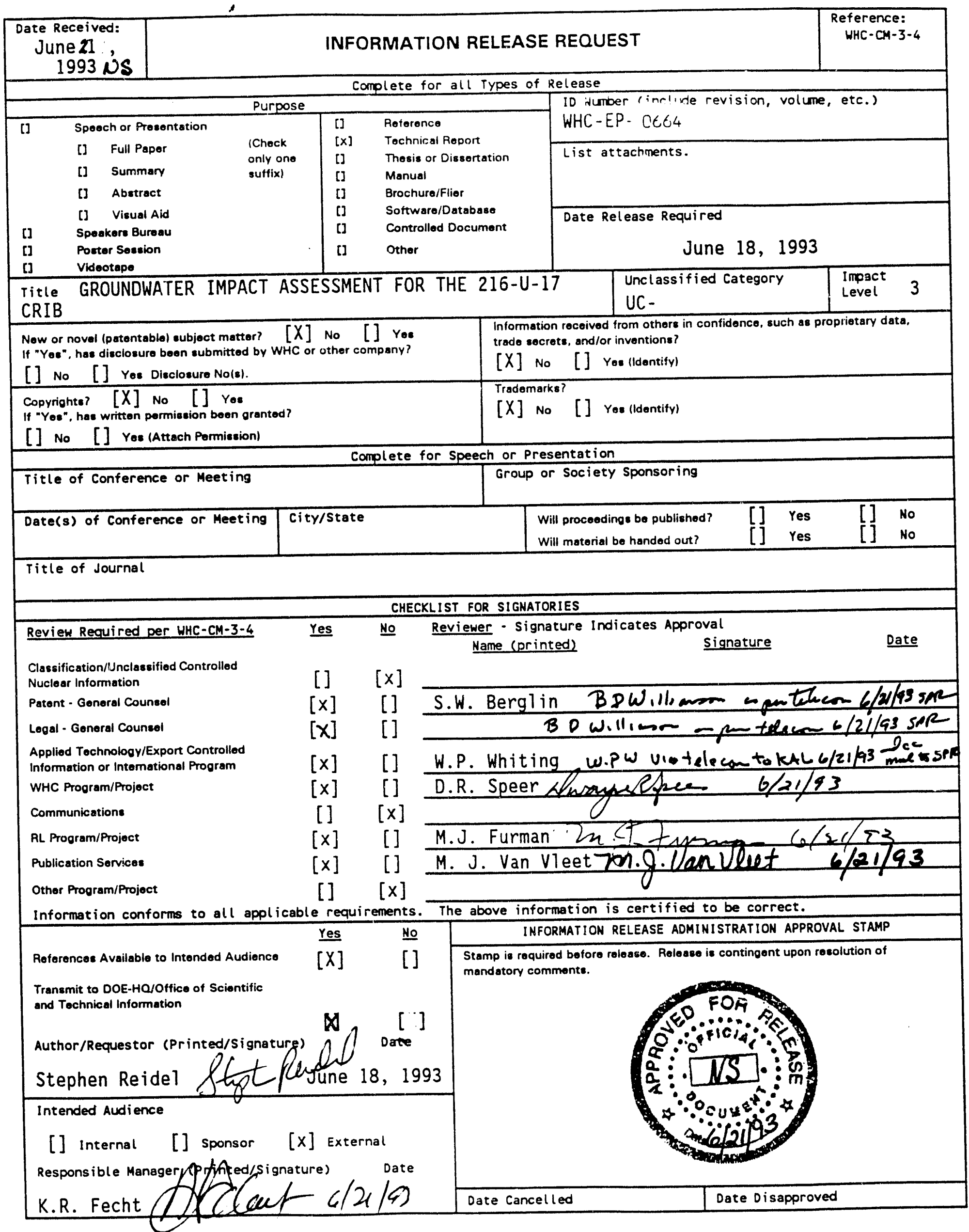




$$
\text { WHC-EP-0664 }
$$

Document Title: Groundwater Impact Assessment of the 216-U-17 Crib, 200 West Area

Prepared by:

Reveiwed by:

Approved by:

Approved by:
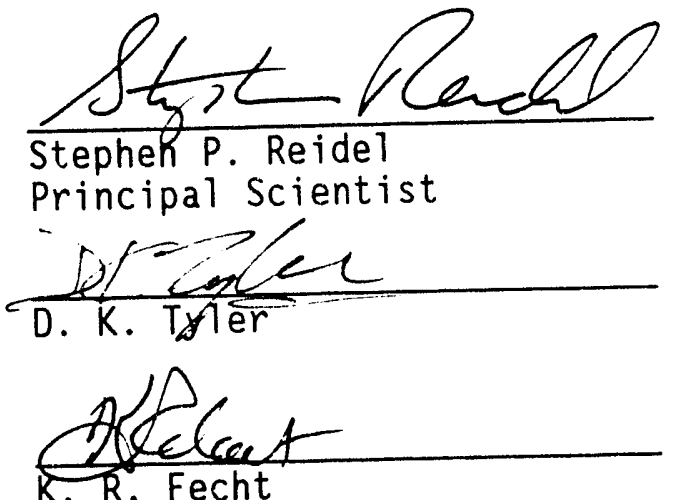

Program Geosciences Function

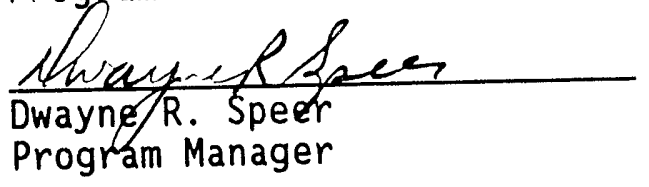

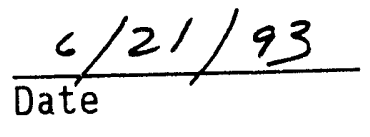

$\frac{6 / 21 / 93}{\text { Date }}$
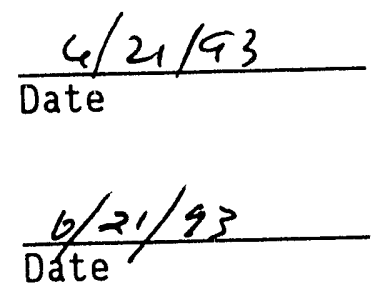
WiHC-EP-0664

This page intentionally left blank. 


\section{EXECUTIVE SUMMARY}

As required by the Hanford Federal Facility Agreement and Consent Order (Tri-Party Agreement milestone M-17-00A), this report assesses the impact to groundwater from discharge of process condensate to the ground at the 216-U-17 Crib. The assessment considers impacts associated with moisture movement through soil beneath the crib and the potential transport of contaminants to the groundwater.

The 216-U-17 Crib is a disposal facility for Uranium-Trioxide $\left(\mathrm{UO}_{3}\right)$ Plant process condensate and related wastewater from the 224-U Building. These facilities are located in the southern part of the 200 west Area. The $216-U-17$ Crib is approximately $91 \mathrm{~m}(300 \mathrm{ft})$ southeast of the $\mathrm{UO}_{3} \mathrm{Pl}$ ant and consists of $46 \mathrm{~m}(150 \mathrm{ft})$ of $15.24-\mathrm{cm}(6-i n$.$) , perforated fiberglass-$ reinforced pipe in a gravel bed that is covered with a polyethylene barrier. The crib capacity is up to $56,781 \mathrm{~L} /$ day $(15,000 \mathrm{gal} /$ day) of process condensate by percolation. Construction was completed in 1987 and the crib became the disposal site for the $\mathrm{UO}_{3} \mathrm{Plant}$ process condensate on January 31,1988 . This crib is a replacement for the 216-U-8 and 216-U-12 Cribs, which operated from Apri1 1960 through September 1972 and from November 1981 until the opening of the 216-U-17 Crib. Discharge to the 216-U-17 Crib was suspended in July 1989 after 41 days of total use. Flow to the crib resumed in August 1992 following approval of the sampling and analysis plan (WHC-SD-CP-PLN-011), ${ }^{2}$ and as directed by the U.S. Department of Energy (DOE).

${ }^{1}$ Ecology, EPA, and DOE, 1990, Hanford Federal Facility Agreement and Consent Order, Washington State Department of Ecology, U.S. Environmental Protection Agency, and U.S. Department of Energy, Olympia, Washington.

${ }^{2} W H C, 1992$, Uranium Oxide $\left(\mathrm{UO}_{3}\right)$ Plant Process Condensate Effluent to 216-U-17 Crib Sampling and Analysis Plan, WHC-SD-CP-PLN-011, Westinghouse Hanford Company, Richland, Washington. 
From August 1992 to June 1993, the $\mathrm{UO}_{3} \mathrm{Pl}$ ant processed stored waste water in preparation for the final processing campaign. The final campaign, a 10-day stabilization run, began in June 1993 and processed remaining uranyl nitrate hexahydrate solution. Following the final campaign, future discharges to the crib will consist of washdown waste generated from transition to shutdown, cleanout activities, and storm water collection. Discharge to the crib will cease in June 1995 when the $\mathrm{UO}_{3} \mathrm{Plant}$ effluent is routed to the Liquid Effluent Treatment Facility.

The $\mathrm{UO}_{3} \mathrm{Plant}$ process condensate stream originates in offgas condensers in the 224-U Building and is essentially a dilute $\mathrm{HNO}_{3}$ solution. From the condensers, the process condensate drains to a surge tank in the 203-U Enclosure. The process condensate is neutralized in the 224-U Building and is pumped to the 216-U-17 Crib for disposal. A new fiber mist eliminator was installed to reduce the amount of contaminants in the waste stream that is discharged to the $216-U-17$ Crib.

The $\mathrm{UO}_{3} \mathrm{Plant}$ has two principal operating modes: standby and calcination. The $\mathrm{UO}_{3} \mathrm{Plant}$ produces $\mathrm{UO}_{3}$ during a uranyl nitrate hexahydrate calcination mode. The volume of condensate generated varies greatly according to operating mode. Between January 1988 and June 1989, the total effluent discharge was $2,109,173 \mathrm{~L}(557,200 \mathrm{gal})$. Discharge to the 216-U-17 Crib resumed in August 1992. The projected volume until termination in 1995 is estimated to be $8,920,000 \mathrm{~L}(2,356,480 \mathrm{gal})$.

The effluent discharged to $216-\mathrm{U}-17 \mathrm{Crib}$ has been designated as "nondangerous, radioactive." The $\mathrm{UO}_{3}$ process condensate contains primarily concentrations of tritium, uranium, ${ }^{99} \mathrm{Tc}$, nitrate, and fluoride. 
Two principal cases of moisture movemen: . and contaminant migration were modeled: a highly conservative base case and a best estimate of all factors. The best estimate was designed to more closely approximate actual conditions.

The predicted concentrations of contaminants in groundwater from continued disposal to the crib were compared with either (1) WAC 173-200 groundwater criteria, ${ }^{3}$ or (2) DOE-derived concentration guides (DCG) (4 mrem/yr equivalent) for those radionuclides not included in WAC 173-200. The highly conservative simulations for the base case (summarized in Table 7) resulted in arrival of contaminants at the water table within 7 years at peak concentrations of about $75 \%$ of the effluent concentrations. This suggests some possible groundwater exceedances for tritium, nitrate, and fluoride. However, these simulations are worst-case or upperbound estimates of potential groundwater impact.

With allowance for anisotropy, a major feature of the best-estimate case, first arrival of the wetting front and tritiated water at the water table does not occur for 125 years. This results in decay of the tritium to about $20,000 \mathrm{pCi} / \mathrm{L}$ (about $10 \mathrm{half}-7 \mathrm{ives}$ ) or very close to the present guideline value $(20,000 \mathrm{pCi} / \mathrm{L})$. Some dilution of the other constituents by soil moisture occurs because lateral spreading distributes the constituents throughout a larger volume of the vadose zone. Mobile contaminants such as ${ }^{99} \mathrm{Tc}$ reach the water table after 1,000 years. Inclusion of a modest amount of retardation for uranium $\left(K_{d}=1\right)$ results in significantly delayed arrival times at the water table (first arrival in about 500 years). In addition, most of the uranium is held in the soil column.

${ }^{3}$ WAC 173-200, 1990, "Water Quality Standards of the State of Washington," Washington Administrative Code, as amended. 
In conclusion, no significant additional impacts on groundwater quality caused by the continued use of the 216-U-17 Crib until 1995 are expected. The primary impact is the distribution of contaminants in the soil column beneath the 216-U-17 Crib and vicinity.

Existing groundwater monitoring wells are considered adequate at this time. However, enhanced vadose zone monitoring to evaluate the predicted extent of lateral spreading and reduced vertical movement as indicated by modeling results may be appropriate.

The numerical simulations show the importance of natural recharge after disposal of effluent to the crib ceases in 1995. Natural recharge becomes the driving force for contaminants reaching the groundwater. To minimize downward movement of contaminants, installation of a permanent cover or barrier over the crib and restoration of the surrounding vegetation could limit net infiltration to the very 10 natural rates $(<1 \mathrm{~mm} / \mathrm{yr})$ that have apparently prevailed on undisturbed 1 and in the 200 West Area Plateau (Murphy et al. 1991)..$^{4}$ A cover and/or surface reclamation could be an effective means of stabilizing vadose zone contaminants beneath the crib.

"Murphy, E. M., J. E. Szescody, and S. J. Phillips, 1991, Moisture Content and Recharge Estimates at the Yakima Barricade Borehole, PNL-SA-20155, Pacific Northwest Laboratory, Richland, Washington. 


\section{CONTENTS}

1.0 INTRODUCTION . . . . . . . . . . . . . . . . . . . . . . . . . . 1

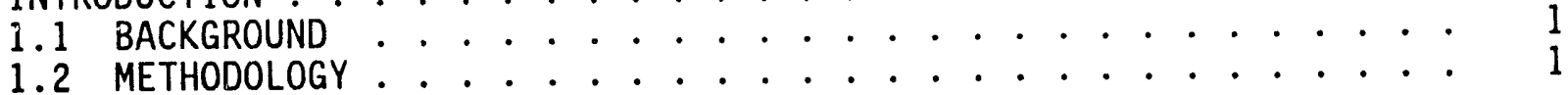

$2.0216-U-17$ FACILITY DESCRIPTION . . . . . . . . . . . . . . . 3

2.1 LOCATION . . . . . . . . . . . . . . . . . 3

2.2 HISTORY OF OPERATION . . . . . . . . . . . . . . . 3

$2.3 \mathrm{UO}_{3}$ COMPLEX FACILITIES ..................... . . . . 7

2.3.1 $\mathrm{UO}_{3} \mathrm{Pl}$ ant Process Facilities............. . 7

2.3.1.1 224-U Building .............. . 7

2.3.1.2 224-UA Building. . . . . . . . . . . . . 7

2.3.1.3 203-U Enclosure............... 7

2.3.1.4 Backpad Area . . . . . . . . . . . . . . . 7

2.3.1.5 211-U Tank Farm............... 7

2.3.1.6 Other Buildings.............. 7

3.0 EFFLUENT CHARACTERISTICS . . . . . . . . . . . . . . . . . . . . 9

3.1 CONTRIBUTING WASTE STREAMS TO $216-\dot{0}-17$ CRIB . . . . . . . . . . . . . 9

3.1.1 System Layout . . . . . . . . . . . . . . . . . 9

3.1.1.1 Contributions from Process Offgas
Condensates......... . . 9

3.1.1.2 Contribution from Raw Water... . . . . . 13

3.2 PROCESS OPERATION . . . . . . . . . . . . . . . . 14

3.3 PROCESS DATA . . . . . . . . . . . . . . . . . . . . 14

3.3.1 Discharge Rates . . . . . . . . . . . . . . . . . 14

3.4 EFFLUENT CONSTITUENTS . . . . . . . . . . . . . . . . . . 16

3.5 CONSTITUENTS OF INTEREST . . . . . . . . . . . . . . . . 16

4.0 GEOHYOROLOGY AND CONCEPTUAL MODEL . . . . . . . . . . . . . . . . . 23

4.1 GEOHYDROLOGY OF THE HANFORD SITE . . . . . . . . . . . . . 23

4.2200 WEST AREA HYDROGEOLOGY . . . . . . . . . . . . . . . . . . 27

$4.3216-U-17$ CRIB SITE GEOHYDROLOGY . . . . . . . . . . . . . . . . 33

4.3.1 216-U-17 Crib Site Stratigraphy . . . . . . . . . 33

4.3.2 Site Geohydrologic Mode1... . . . . . . . . . . 33

4.3.3 Groundwater Quality . . . . . . . . . . . . . . . . 35

4.3.4 216-U-17 Crib Site Groundwater Quality . . . . . . . 52

4.4 CONCEPTUAL MODEL ELEMENTS . . . . . . . . . . . . . . . 54

4.4.1 Moisture Movement . . . . . . . . . . . . . . . . 54

4.4.2 Movement of Constituents of Interest . . . . . . . 59

5.0 IMPACT ASSESSMENT . . . . . . . . . . . . . . . . . . . . . 61

5.1 FLOW AND TRANSPORT MODEL . . . . . . . . . . . . . . 61

5.1.1 Spatial Domain of Crib Mode1 . . . . . . . . . . . . . 61

5.1.2 Hydraulic, Soil, and Transport Properties . . . . . . . 67

5.1.3 Initial and Boundary Conditions . . . . . . . . . 68

5.1.3.1 Flow Conditions.............. 68

5.1.3.2 Transport Conditions ........... . 71

5.1.4 Simulation Cases................. . 71

5.1.4.1 Base Case.................. . 73

5.1.4.2 Source Term Representation . . . . . . . . 88

5.1.4.3 Simplified Generic Stratigraphy ... . . . . 10?

5.1.4.4 Recharge Rate................ 103 


\section{CONTENTS (cont.)}

5.1.4.5 Best-Estimate Simulation . . . . . . . . 110

5.2 HYDRAULIC IMPACTS - A SUMMARY . . . . . . . . . . . . . . . . 141

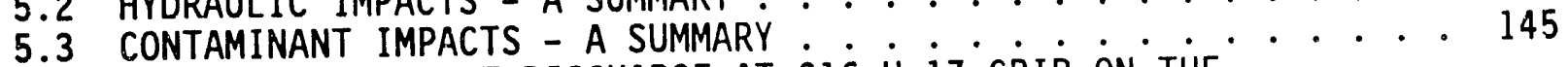

5.4 IMPACT OF EFFLUENT DISCHARGE AT 216-U-17 CRIB ON THE

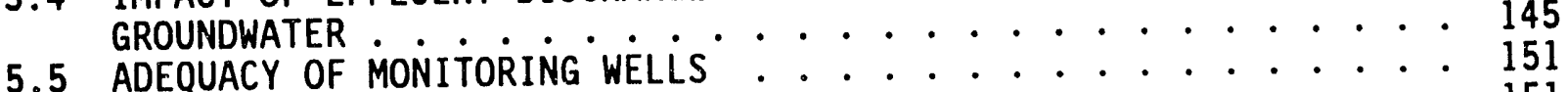

5.5 ADEQUACY OF MONITORING 5.6 IMPLICATIONS . . . . . . . . . . . . . . . . . . . . . . . 151

6.0 CONCLUSIONS . . . . . . . . . . . . . . . . . . . . . . 153

7.0 REFERENCES . . . . . . . . . . . . . . . . . . . . . . . . . 155

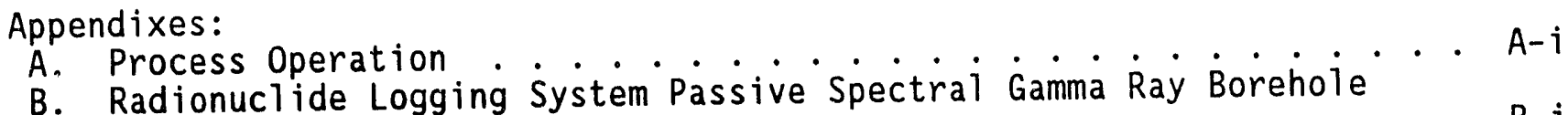

Survey Report ....................... . B-i 


\section{LIST OF FIGURES}

1 Location Map for the $216-\mathrm{U}-17 \mathrm{Crib}$. . . . . . . . . . . . . . . 4

2 Map Showing Main Features of the $\mathrm{UO}_{3} \mathrm{Pl}$ ant Complex and Transfer Line ........................ 5

3 Detailed Drawing of the 216-U-17 Crib . . . . . . . . . . 6

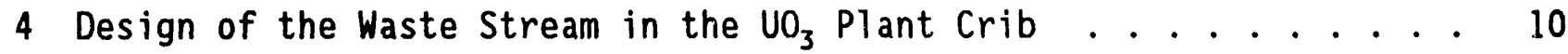

5 Flow Sheet of Contributors to the Process Condensate . . . . . . . . 1 i

6 Flow Rate 1988-19ع́' . . . . . . . . . . . . . . . . . 15

7 Projected Volume of Effluent Until 1995 . . . . . . . . . . . 17

8 Location Map of the Hanford Site and the Pasco Basin . . . . . . . 24

9 Stratigraphic Nomenclature of the Hanford Site . . . . . . . . . 25

10 Generalized Stratigraphy for the Hanford Site Showing the

11 Location of Water Disposal Ponds on the Hanford Site . . . . . . . . 28

12200 Areas Water Table Map, December 1991. . . . . . . . . . . 31

13 216-U-17 Site Diagrammatic Geology . . . . . . . . . . . . 36

14 Location of Cross Sections . . . . . . . . . . . . . . . 37

15 East-West Geologic Cross Section Through the 216-U-17 Crib and 38

16 North-South Geologic Cross Section Through the 216-U-17 Crib and Vicinity . . . . . . . . . . . . . . . . . . . 39

17 Geohydrologic Model for the 216-U-17 Crib . . . . . . . . . . . . 40

18 Chromium Plume Map, 200 West Area . . . . . . . . . . . . . . . 41

19 Fluoride Plume Map, 200 West Area . . . . . . . . . . . . . 42

20 Carbon Tetrachloride Plume Map, 200 West Area . . . . . . . . . . . . 44

21 Nitrate Plume Map, 200 West Area . . . . . . . . . . . . . . 45

22 Gross Alpha Plume Map, 200 West Area . . . . . . . . . . . . . 46

23 Gross Beta Plume Map, 200 West Area . . . . . . . . . . . . . . . . 47

24 Iodine-129 Plume Map, 200 West Area . . . . . . . . . . . . . . . 48 


\section{LIST OF FIGURES (cont.)}

25 Technetium-99 Plume Map, 200 West Area . . . . . . . . . . . 49

26 Tritium Plume Map, 200 West Area . . . . . . . . . . . . . 50

27 Uranium Plume Map, 200 West Area . . . . . . . . . . . . . 51

28 Process Condensate Discharge History of the $\mathrm{UO}_{3} \mathrm{Pl}$ ant Cribs . . . . 53

29 Water Table Map Showing Concentrations of Uranium . . . . . . . . . 55

30 Water Table Map Showing Concentrations of Technetium-99 . . . . . 56

31 Impact of Adjacent Facilities on Groundwater at the 216-U-17 Crib . 57

32 Kolmogorov-Smirnov Two-Sample Test of Contaminants in Upgradient and Downgradient Wells at 216-U-17 $\mathrm{Crib}$............. 58

33 Idealized Longitudinal Cross Section of Stratigraphy Under the 216-U-17 Crib....................

34 Summary of Boundary Conditions for PORFLO-3 Model of 216-U-17 Crib Operation ......................

35 Simulation of 216-U-17 Crib Base Case Steady State . . . . . . 75/76

36 Simulation of 216-U-17 Crib Relative Saturation Contours at 1 Year After Start of Crib Operation . . . . . . . . . . . . . 75/76

37 Simulation of 216-U-17 Crib Relative Saturation Contours at 3 Years After Start of Crib Operation . . . . . . . . . . . 777/78

38 Simulation of 216-U-17 Crib Relative Saturation Contours at 5 Years After Start of Crib Operation . . . . . . . . . . . 77/78

39 Simulation of 216-U-17 Crib Relative Saturation Contours at 7 Years After Start of Crib Operation . . . . . . . . . . . 79/80

40 Simulation of 216-U-17 Crib Relative Saturation Contours at 15 Years After Start of Crib Operation . . . . . . . . . . 79/80

41 Simulation of 216-U-17 Crib - Base Case Time History of Relative Concentration ....................

42 Simulation of 216-U-17 Crib - Base Case with Unit Thickness Relative Saturation Contours at 3 Years After Start of Crib Operation.

43. Simulation of 216-U-17 Crib - Base Case with Unit Thickness Relative Saturation Contours at 5 Years After Start of Crib Operation ....................... . 83/84 


\section{LIST OF FIGURES (cont.)}

44 Simulation of 216-U-17 Crib - Base Case with Unit Thickness Relative Saturation Contours at 7 Years After Start of Crib .....................

45 Simulation of 216-U-17 Crib - Base Case with Unit Thickness Time History of Relative Concentration . . . . . . . . . . .

46 Simulation of 216-U-17 Crib - Base Case with Zero Flux Boundaries - Relative Saturation Contours at 7 Years After Start of Crib Operation . . . . . . . . . . . . . . . . .

47 Simulation of 216-U-17 Crib - Point Source with Actual Gross Discharge - Relative Saturation on June 30, 1989 . . . . . . . 91/92

48 Simulation of 216-U-17 Crib - Point Source with Actual Gross Discharge - Relative Saturation on June 30,1995 . . . . . . .

49 Simulation of 216-U-17 Crib - Point Source with Actual Gross Discharge - Time History of Relative Concentration . . . . . . .

50 Simulation of 216-U-17 Crib - Nonuniform Line Source with Gross Actual Discharge - Relative Saturation on June 30, 1989 . .

51 Simulation of 216-U-17 Crib - Nonuniform Line Source with Gross Actual Discharge - Relative Saturation on June 30, 1995 - . 99/100

52 Simulation of 216-U-17 Crib - Uniform Line Source with Gross Actual Discharge - Relative Saturation on June 30,1989 . . . . 101/102

53 Simulation of 216-U-17 Crib - Uniform Line Source with Gross

Actual Discharge - Relative Saturation on June 30, 1995 . . . . 101/102

54 Simulation of 216-U-17 Crib - Steady-Siate Moisture Distribution - Generic Stratigraphy. . . . . . . . . . . 105/106

55 Simulation of 216-U-17 Crib - Point Source - Generic Stratigraphy - Relative Saturation on June 30,1989 . . . . . . 105/106

56 Simulation of 216-U-17 Crib - Point Source - Generic Stratigraphy - Relative Saturation on July 31, 1992 . . . . . . 107/108

57 Simulation of 216-U-17 Crib - Point Source - Generic Stratigraphy - Relative Saturation on June 30, 1995 . . . . . . 107/108

58 Simulation of 216-U-17 Crib - Point Source - Generic Stratigraphy - Time History of Relative Concentration . . . . . 109

59 Simulation of 216-U-17 Crib - Assumed $5 \mathrm{~cm} / \mathrm{yr}$ Recharge Rate Relative Saturation on January 31,1988 . . . . . . . . . 111/112

60 Simulation of 216-U-17 Crib - Assumed $5 \mathrm{~cm} / \mathrm{yr}$ Recharge Rate 20-Year Time History of Relative Concentration . . . . . . . . 
WHC-EP-0664

LIST OF FIGURES (cont.)

61 Simulation of 216-U-17 Crib - Assumed $5 \mathrm{~cm} / \mathrm{yr}$ Recharge Rate 50-Year Time History of Relative Concentration . . . . . . .

62 Simulation of 216-U-17 Crib - Assumed $5 \mathrm{~cm} / \mathrm{yr}$ Recharge Rate Time History of Relative Saturation . . . . . . . . . . . .

63 Simulation of 216-U-17 Crib - Time History of Uranium Concentration Under the Point Source . . . . . . . . . . .

64 Simulation of 216-U-17 Crib - Point Source with Monthly Actual Discharges - Relative Saturation Contours on June 30,1995 . . . 117/118

65 Simulation of 216-U-17 Crib - Point Source with Monthly Actual Discharges - Time History of Uranium Concentration . . . . . . .

66 Simulation of 216-U-17 Crib - Construction of Best-Estimate Case - Full Thickness and Actual Gradient in the Aquifer - Time History of Relative Saturation . . . . . . . . . . . . .

67 Simulation of 216-U-17 Crib - Construction of Best-Estimate Case - Ful1 Thickness and Actual Gradient in the Aquifer - Time History of Uranium Concentration

68 Simulation of 216-U-17 Crib - Construction of Best-Estimate Case - Full Thickness and Actual Gradient in the Aquifer Uranium Concentration Contours on January 31, 2038

69 Simulation of 216-U-17 Crib - Construction of Best-Estimate Case - Full Thickness and Actual Gradient in the Aquifer Uranium Concentration Contours on January 31, 2088 . . . . . . 123/124

70 Assumed Recharge Rate for 216-U-17 Crib Site and Polyvinyl Chloride Membrane . . . . . . . . . . . . . . .

71 Simulation of 216-U-17 Crib - Construction of Best-Estimate Case - Revised Discharge and Recharge Rates - Uranium Concentration Contours on January 31,2038

72 Simulation of 216-U-17 Crib - Construction of Best-Estimate Case - Revised Discharge and Recharge Rates - Uranium Concentration Contours on January 31, 2088 . . . . . . . . 127/128

73 Simulation of 216-U-17 Crib - Best-Estimate Case - Time History of Relative Saturation

74 Simulation of 216-U-17 Crib - Best-Estimate Case - Relative Saturation Contours on January 31, 1998 . . . . . . . . . . 133/134

75 Simulation of 216-U-17 Crib - Best-Estimate Case - Relative Saturation Contours on January 31,2018 
LIST OF FIGURES (cont.)

76 Simulation of 216-U-17 Crib - Best-Estimate Case - Relative Saturation Contours on January 31,2088 . . . . . . . . . . 135/136

77 Simulation of 216-U-17 Crib - Best-Estimate Case - Relative

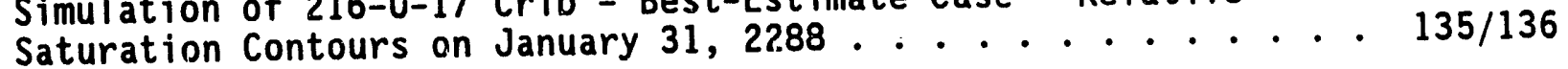

78 Simulation of 216-U-17 Crib - Best-Estimate Case - Uranium

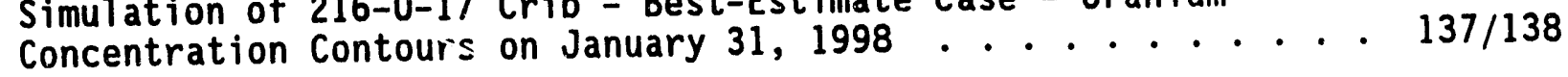

79 Simulation of 216-U-17 Crib - Best-Estimate Case - Uranium Concentration Contours on January 31,2018 . . . . . . . . . . 137/138

80 Simulation of 216-U-17 Crib - Best-Estimate Case - Uranium

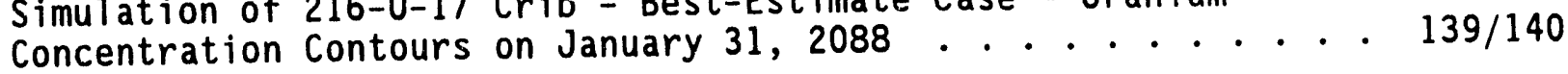

81 Simulation of 216-U-17 Crib - Best-Estimate Case - Uranium Concentration Contours on January 31,2288 . . . . . . . . . 139/140

82 Simulation of 216-U-17 Crib - Best-Estimate Case - Technetium Concentration Contours on January 31,2988 . . . . . . . . . . . 143/144

83 April-May 1993 Process Condensate Concentrations from Tank X-37 with Fiber Mist Eliminator On and off for (A) [upper left] Technetium-99 in $\mu \mathrm{Ci} / \mathrm{L}$, (B) [upper right] Uranium in $\mathrm{g} / \mathrm{L}$, (C) [lower left] $\mathrm{pH}$, and (D) [lower right] Nitrate Molarity...

84 August 1992 - May 1993 Process Condensate Concentrations at 216-U-17 Crib for (A) [upper left] Gross Alpha in $\mu \mathrm{Ci} / \mathrm{L}$, (B) [upper right] Potassium in $\mathrm{mg} / \mathrm{L}$, (C) [lower left] Gross Beta in $\mu \mathrm{Ci} / \mathrm{L}$, and (D) [lower right] Potassium Nitrate Molarity.

85 August 1992 - May 1993 Process Condensate Concentrations at 216-U-17 Crib for (A) [upper left] $\mathrm{pH}$, (B) [upper right] Technetium-99 in $\mu \mathrm{C} i / L$, (C) [lower left] Phosphate Molarity,

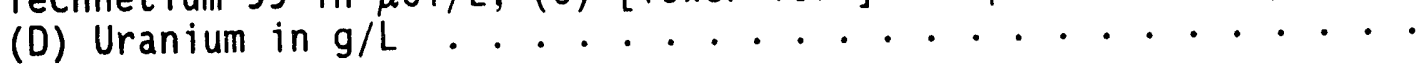

86 August 1992 - May 1993 Process Condensate Concentrations at 216-U-17 Crib for (A) [upper left] Chromium in $\mathrm{mg} / \mathrm{L}$, (B) [upper right] Fluoride Molarity, and (C) Tritium in $\mu \mathrm{Ci} / \mathrm{L} . . . .$. . 
WHC-EP-0664

This page intentionally left blank. 
WHC-EP-0664

\section{LIST OF TABLES}

1 Contributors to $\mathrm{NO}_{3} \mathrm{Plant}$ Process Condensate . . . . . . . . . 12

2 Process Condensate Generation Rates 1988 . . . . . . . . . . . 16

3 Projected Volume of Discharge to 216-U-17 Crib . . . . . . . . 18

4 Monthly Summary of Radioactive Liquid Discharged to the .

5 Nonradioactive Constituents . . . . . . . . . . . . . . . 20

6 Forecast of Effluent Concentrations and Quantities for 216-U-17 Crib.................... 21

7 Summary of Numerical Simulation Cases, Soil Column Transport Rates, and Maximum Solute Concentrations in Soil Moisture . . . . . 63

8 HydrauTic Properties Used for Material Types (Zones) . . . . . . . 65

9 Volumetric Moisture Content Parameters for the 216-U-17 Crib Model . . . . . . . . . . . . . . . . 68

10 Soil Properties Used for the 216-U-17 Crib Model . . . . . . . . . 69

11 Initial Soil Moisture Tension from Wetting Curves Based on $10 \mathrm{~cm} / \mathrm{yr}$ Recharge Rate . . . . . . . . . . . . . . . 70

12 Gross Actual/Planned Fluid Discharge . . . . . . . . . . . . 93

13 Nonuniform Discharge Distribution . . . . . . . . . . . . 103

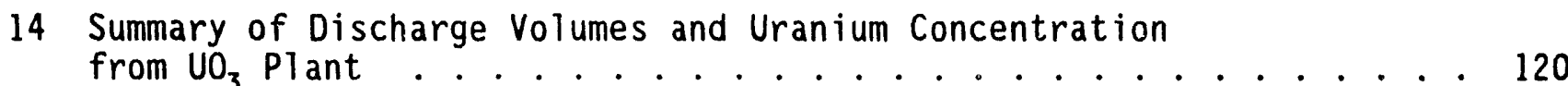

15 Revised Discharges for Run 17................... 121

16 Concentration Guides for Evaluation Potential 


\section{LIST OF TERMS}

$\begin{array}{ll}\text { CRBG } & \text { Columbia River Basalt Group } \\ \text { DCG } & \text { derived concentration guide } \\ \text { DOE } & \text { U.S. Department of Energy } \\ \text { ECOlogy } & \text { Washington State Department of Ecology } \\ \text { EPA } & \text { U.S. Environmental Protection Agency } \\ \text { PUREX } & \text { Plutonium-Uranium Extraction (Facility) } \\ \text { PVC } & \text { polyvinyl chloride } \\ \text { REDOX } & \text { Reduction Oxidation (Plant) } \\ \text { RL } & \text { DOE, Richland Operations Office } \\ \text { Tri-Party } & \text { Hanford Federal Facility Agreement and Consent order } \\ \text { Agreement } & \\ \text { UNH } & \text { uranyl nitrate hexahydrate } \\ \text { UO } & \text { Uranium Trioxide (Plant) } \\ \text { WHC } & \text { Westinghouse Hanford Company }\end{array}$


WHC-EP-0664

GROUNDWATER IMPACT ASSESSMENT FOR THE
$216-U-17$ CRIB, 200 WEST AREA

\subsection{INTRODUCTION}

Groundwater impact assessments for a number of liquid effluent receiving sites are required by the Hanford Federal Facility Agreement and Consent Order. (Ecology et al. 1990) (Tri-Party Agreement) milestones M-17-00A and M-17-00B. This report assesses the impacts to groundwater from the disposal of effluent to the 216-U-17 Crib in 200 West Area.

\subsection{BACKGROUND}

In response to public comments on the original Tri-Party Agreement, and at the request of the signatories on the Tri-Party Agreement, the U.S. Department of Energy (DOE), Richland Operations Office (RL) conducted a study to assess the impact of liquid effluents discharged to the ground at the Hanford Site (WHC 1990a, 1990b). The U.S. Environmental Protection Agency (EPA) and the Washington State Department of Ecology (Ecology) expressed concerns regarding uncertainties in the evaluations made by $\mathrm{RL}$. Foremost among these concerns were the lack of site-specific data, the need to consider interactions with adjacent liquid discharge facilities, and the need for more rigorous models of contaminant transport. As a result of these concerns, the RL, Ecology, and EPA (the three parties) created a series of Tri-Party Agreement milestones (M-17-00A, M-17-00B, M-17-13, and M-17-13A) that pertain to groundwater impact assessments.

Tri-Party Agreement milestones $\mathrm{M}-17-00 \mathrm{~A}$ and $\mathrm{M}-17-00 \mathrm{~B}$ require impact assessments for Phase I and II waste streams. Phase I and II waste streams are defined in Stordeur and Flyckt (1988). The 216-U-17 Crib received a higher priority Phase II waste stream classification. Tri-Party Agreement milestone M-17-13 required the development of a methodology for assessing the impact of liquid effluent discharge on groundwater, which resulted in the document $A$ Methodology for Assessing Impacts to Groundwater from Disposal of Liquid Effluent to the Soil at the Hanford Site (Tyler 1991). A schedule for performing the assessments at 13 receiving sites was completed 30 days after regulatory approval of the methodology document, as required by Tri-party Agreement milestone $\mathrm{M}-17-13 \mathrm{~A}$. The $216-\mathrm{U}-17 \mathrm{Crib}$ is identified in the schedule as one of the first receiving sites to undergo a groundvater impact as ses sment.

\subsection{METHODOLOGY}

Preparation of the groundwater impact assessment for the 216-U-17 Crib followed the aforementioned methodology document (Tyler 1991). Included in that document is the categorization of each of the 13 receiving sites into 1 of 3 levels based on the amount of effort needed to perform the assessment. A level 1 receiving site groundwater impact assessment relies on available information. A groundwater impact assessment of a level 2 receiving site may require nonintrusive field work to verify the extent of existing 
contamination. A level 3 site may require intrusive field work. If it is discovered that existing information is inadequate through the course of performing a level 1 impact assessment, the assessment may be raised to a level 2 or 3 assessment.

The methodology document outlines several of the following tasks to be conducted as part of the groundwater impact assessment for level 1 receiving sites.

- Prepare and present plan describing how the groundwater assessment will be conducted

- Characterize the liquid effluent stream

- Evaluate the site-specific hydrogeology

- Develop a receiving site conceptual model reievant to moisture and contaminant movement

- Assess the hydrologic impact of the liquid effluent stream

- Assess the contaminant impact of the liquid effluent stream

- Evaluate the adequacy of the existing monitoring well network

- Prepare a written report of the results.

The tasks required for level 2 and 3 receiving sites are similar to those outlined above, but also include field work-related activities. The 216-U-17 Crib was categorized as a level 1 receiving site, primarily on the basis of effluent characteristics (Toebe et a1. 1990).

Several key assumptions inherent to all groundwater impact assessments are explained in the methodology document and warrant summarizing here. For this impact assessment, the following assumptions are relevant.

- The expected level of impact from use of the receiving site determines how well the chemistry, geology, and hydrology need to be understood.

- Modeling sophistication is tailored to available information and the expected level of impact of the receiving site.

- Historical data are fully useable. 


\subsection{6-U-17 FACILITY DESCRIPTION}

\subsection{LOCATION}

The 216-U-17 Crib is located at the southern end of the 200 West Area (Figure 1). The crib is approximately $91 \mathrm{~m}(300 \mathrm{ft})$ southeast of the Uranium Trioxide $\left(\mathrm{UO}_{3}\right)$ Plant; it lies $61 \mathrm{~m}(200 \mathrm{ft})$ west of Beloit Avenue and $61 \mathrm{~m}$ $(200 \mathrm{ft})$ south of $16 \mathrm{th}$ Street. A dedicated pipeline about $366 \mathrm{~m}(1,200 \mathrm{ft})$ long transports the $\mathrm{UO}_{3} \mathrm{Pl}$ ant process condensate from the 224- $U$ Building to the 216-U-17 Crib as shown in Figure 2. The crib consists of about $46 \mathrm{~m}$ $(150 \mathrm{ft})$ of $15.24-\mathrm{cm}(6-\mathrm{in}$.$) perforated fiberglass-reinforced pipe in a gravel$ bed that is covered with a polyethylene barrier, backfilled, and stabilized (Figure 3). The crib is sized to dispose, by percolation, of up to $56,781 \mathrm{~L} /$ day $(15,000 \mathrm{gal} /$ day $)$ of process condensate. No corrosive solutions have ever been discharged to the 216-U-17 Crib (Toebe et al. 1990).

\subsection{HISTORY OF OPERATION}

The 216-U-17 Crib was constructed in 1987 and became the disposal site for the $\mathrm{UO}_{3} \mathrm{Plant}$ process condensate on January 31,1988 . This crib is a replacement for the 216-U-12 Crib, which operated from April 1960 through September 1972, and from November 1981 until the opening of the 216-U-17 Crib.

Discharge to the 216-U-17 Crib was suspended in July 1989. At this time, the crib operated a total of 41 days. Between July 1989 and August 1992, wastewater was stored at the $\mathrm{UO}_{3}$ Plant until the waste stream regulatory status could be determined.

Flow to the crib resumed in August 1992 following approval of the sampling and analysis plan (WHC 1992) and as directed by the DOE.

From August 1992 to April 1993, the $\mathrm{VO}_{3}$ Plant processed stored waste water in preparation for the final processing campaign. The final campaign, a 10-day stabilization run to process remaining uranyl nitrate hexahydrate (UNH) solution, started in June 1993. The stabilization campaign proceeds in two phases. The first phase, precampaign processing, concentrates the liquid material so it can be more efficiently converted to a solid. The second phase of the campaign completes the UNH concentration and converts it to $\mathrm{UO}_{3}$. Following the final campaign, future discharge to the crib will be washdown waste generated from transition to shutdown, cleanout activities, and storm water collection.

Discharge will cease in June 1995 when the $\mathrm{UO}_{3} \mathrm{Plant}$ will tiecome connected to the Liquid Effluent Treatment Facility. 
WHC-EP-0664

Figure 1. Location Map for the 216-U-17 Crib.

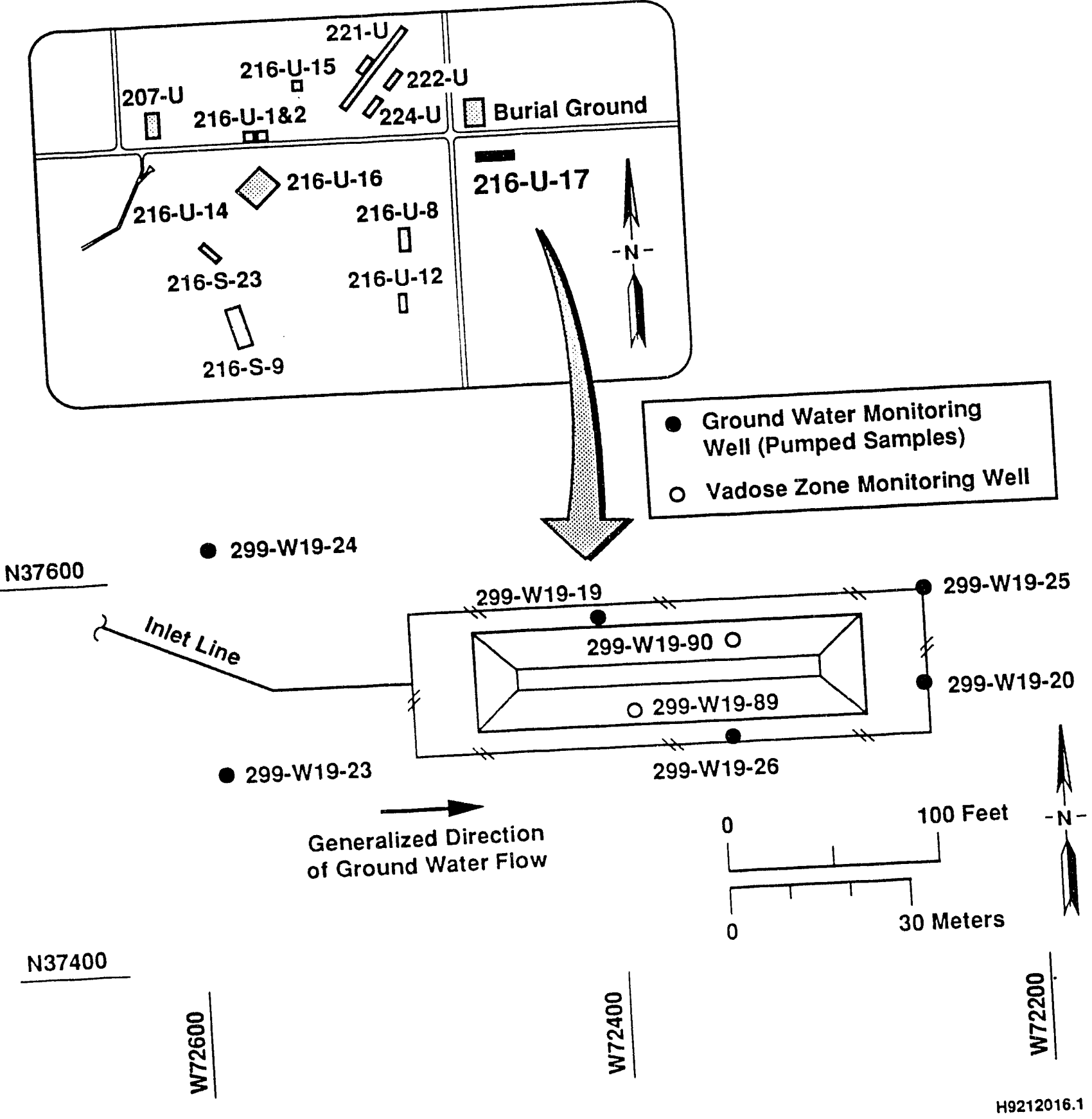


Figure 2. Map Showing Main Features of the $\mathrm{UO}_{3}$ Plant Complex and Transfer Line.

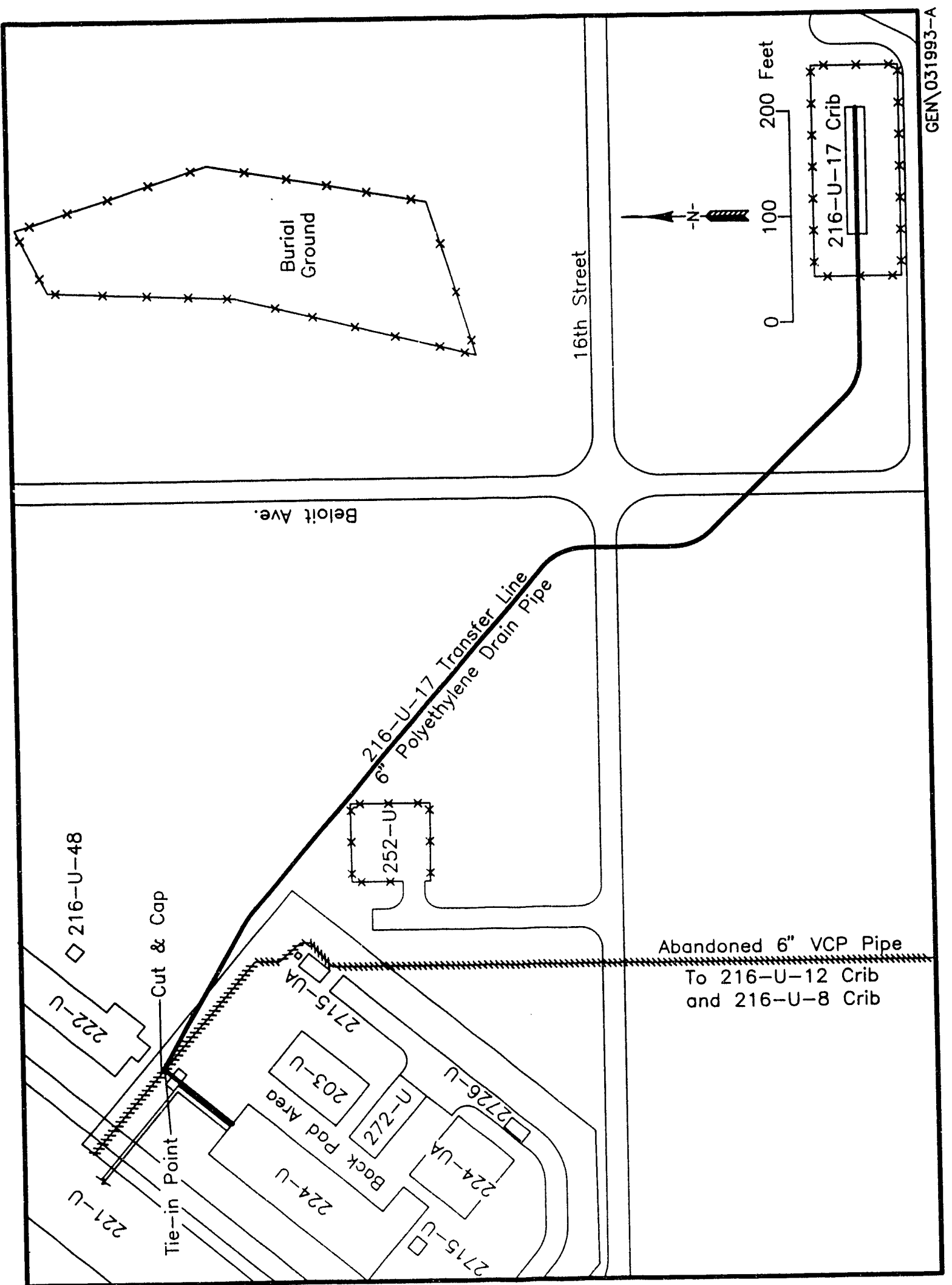


Figure 3. Detailed Drawing of the 216-U-17 Crib.

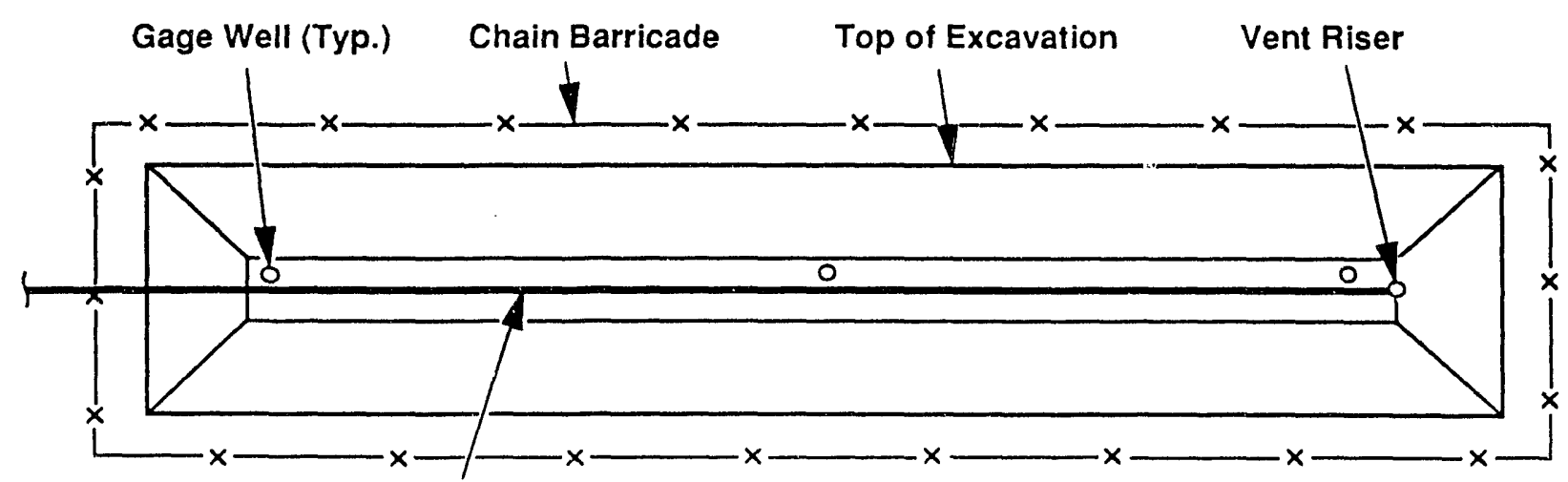

6 in. Perforated Pipe

Crib Plan
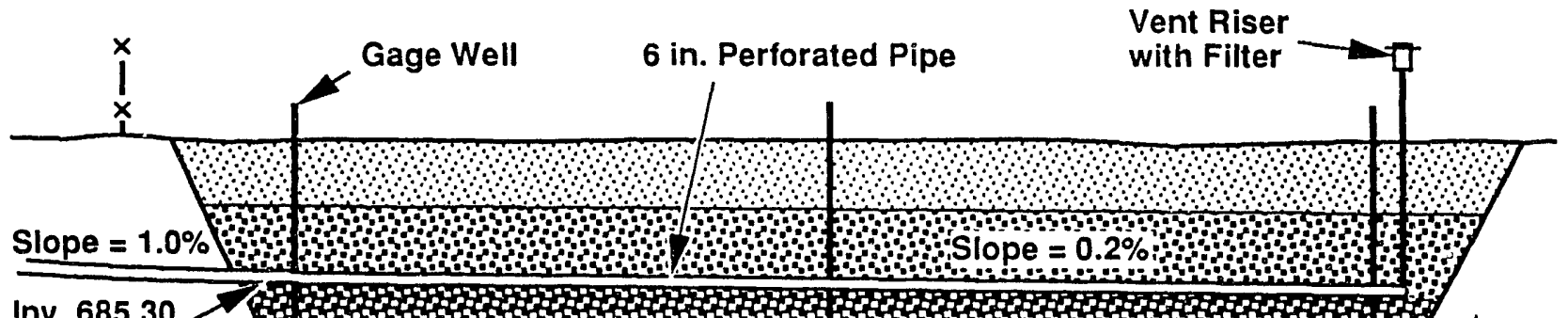

Inv. 685.30

El. 675.00

Concrete

Base

$150 \mathrm{ft}$

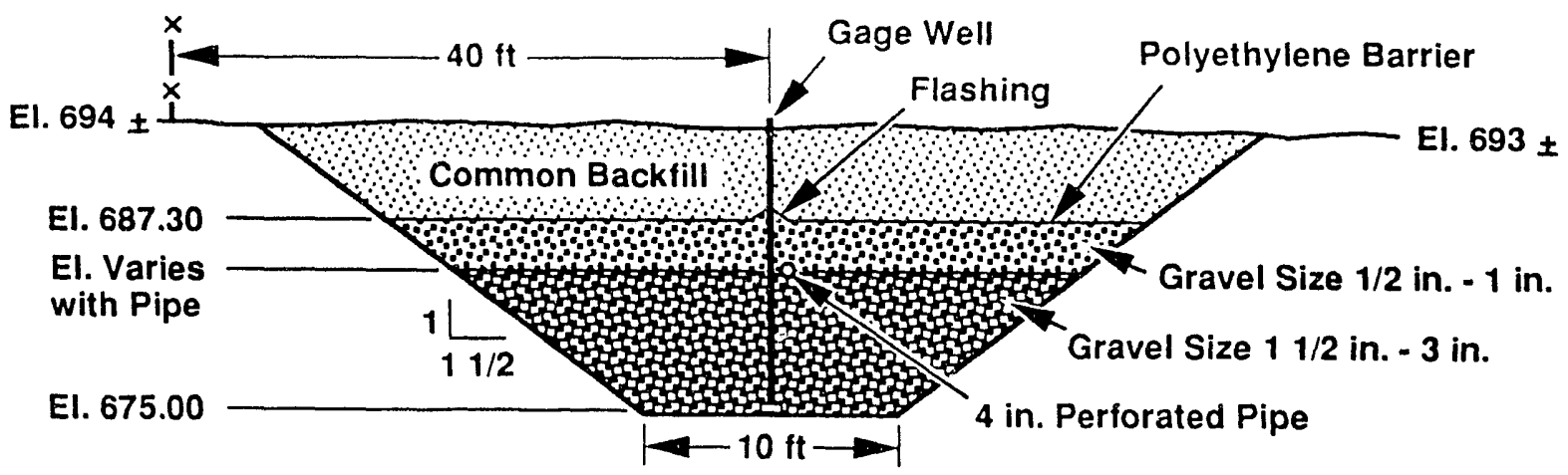

Cross Section 


\section{$2.3 \mathrm{UO}_{3}$ COMPLEX FACILITIES}

\subsection{1 $\mathrm{UO}_{3} \mathrm{Plant}$ Process Facilities}

The $\mathrm{VO}_{3} \mathrm{Plant}$ is located in the south-central portion of the 200 West Area of the Hanford Site (see Figure 1). The plant consists of two primary processing facilities, Buildings 224-U and 224-UA, and several additional facilities as shown in Figure 2. The following description is taken from Toebe et al. (1990), which provides a detaiced description of the $\mathrm{UO}_{3} \mathrm{Plant}$ complex.

2.3.1.1 224-U Building. The 224-U Building is a 44- by $28-\mathrm{m}$, roofed concrete-walled building that was constructed in 1944. This building received UNH solution from the Plutonium-Uranium Extraction (PUREX) Facility and concentrated it for processing in Building 224-UA. A nitric acid recirculation loop from Building 224-U scrubbed the calciner offgas system in Building 224-UA to dissolve fine-grained, entrained $\mathrm{UO}_{3}$ particles.

2.3.1.2 224-UA Building. The 244-UA Building is a 29- by $16-\mathrm{m}$, steel-walled and framed building that was constructed in 1957. This building converted UNH from Building 224-U to $\mathrm{UO}_{3}$ powder and packaged it for offsite shipment.

2.3.1.3 203-U Enclosure. The 203-U Enclosure is a 24- by 13.7-m, roofless, concrete-diked process chemical tank storage facility. The 203-U Enclosure stored feed UNH from PUREX, recycled UNH for return to the PUREX Facility, and process condensate and potassium hydroxide. Solutions collected in the 203-U Enclosure sump were transferred to Building 224-U for further processing.

2.3.1.4 Backpad Area. The backpad area between Buildings 224-U, 203-UX, 224-UA, and the 203-U Enclosure contains additional tanks and piping that connect the main process buildings. The concrete-diked 203-UX enclosures in the backpad area adjacent to the 224-U Building contain tanks that stored concentrated UNH from the 224-U Building before it was processed in 224-UA Building. Any rainfall or uranium-bearing solutions collected in sumps in the backpad area were routed to Building 224-U for further processing.

2.3.1.5 211-U Tank Farm. The 211-U Tank Farm north of the 221-U Building contains four storage tanks where nitric acid recovered at the $\mathrm{UO}_{3} \mathrm{Pl}$ ant was staged for rail shipment to the PUREX Facility. Sumps in the 211-U area drained to the $\mathrm{UO}_{3} \mathrm{Plant}$ wastewater stream. There is no connection from this facility to the $\mathrm{UO}_{3} \mathrm{Plant}$ process condensate stream.

2.3.1.6 Other Buildings. Former process and laboratory buildings 221-U, $271-U, 222-U$, and other tanks at 211-U Building are no longer in operation. While these retired facilities are not directly associated with the $\mathrm{UO}_{3} \mathrm{Plant}$, rainwater run-off and heating, ventilation, and air conditioning condensates from these buildings still drain to the $\mathrm{UO}_{3} \mathrm{Pl}$ ant wastewater system. However, there is no connection from these facilities to the $\mathrm{UO}_{3} \mathrm{Plant}$ process condensate stream. 
WHC-EP-0664

This page intentionally left blank. 


\subsection{EFFLUENT CHARACTERISTICS}

\subsection{CONTRIBUTING WASTE STREAMS TO 216-U-17 CRIB}

The $\mathrm{UO}_{3} \mathrm{Pl}$ ant process condensate stream originates in offgas condensers in Building 224-U, which process contributor streams from throughout the $\mathrm{UO}_{3} \mathrm{Pl}$ ant complex (Figure 4). From the condensers, the process condensate drains to a surge tank (Tank $X-37$ ) in the 203-U Enclosure. The process condensate is neutralized in Building 224-U and is pumped to the 216-U-17 Crib for disposa1. Redundant pH probes, transmitters, alarm switches, and stripchart recorders monitor the $\mathrm{pH}$ of the process condensate at a location just before exiting the 224-U Building. The following is derived from Toebe et al. (1990), which provides a more detailed description.

\subsubsection{System Layout}

Direct contributors to the $\mathrm{UO}_{3} \mathrm{Pl}$ ant process condensate are 1 isted in Table 1. The processes that generate these contributors are described in Section 3.2. Figure 4 shows the pathways of the process condensate as they flow to Tank $C-9$. Condensate is pumped for use as reflux to the TA-3 acid absorber tower from this tank; the excess becomes waste and is routed from Tank C-9 to Tank $X-37$ before neutralization. All contributors to the process condensate are active during calcination mode. Contributors that are also in operation during standby mode (see Appendix A, Section Al.2) are listed in Table 1. Process data and other information pertaining to the contributor compositions and flowrates are described in section 3.3 .

Most of the contributors to the process condensate are acidic. The $\mathrm{UO}_{3}$ Plant process condensate neutralization system controls the process condensate $\mathrm{pH}$ before discharge to the 216-U-17 $\mathrm{Crib}$.

3.1.1.1 Contributions from Process offgas Condensates. With the exception of raw water, phosphoric acid, and potassium hydroxide, the contributors to the process condensate are condensates formed when the corresponding process offgas stream passes through the E-D-3 and/or E-B-3 condensers (see Figure 4). Figure 5 is a flowsheet of the process. Condensates from the condensers drain to Tank C-9, via submerged inlet lines, which provide a water seal between $E-D-3$ and $E-E_{1}-3$. From Tank $C-9$ some of the condensate is pumped to nitric acid absorber tower $T-A-3$, and the remainder overflows to surge Tank $X-37$. From Tank $X-37$, the condensate is pumped to Tank $C-5$, neutralized, and discharged to the 216-U-17 Crib.

A fiber mist eliminator has been installed in the $\mathrm{UO}_{3} \mathrm{Plant}$ concentrator offgas 1 ine between Tank D-13 and E-D-3 condenser (see Figure 5). The mist eliminator captures UNH droplets entrained from the E-D-2, E-D-6, E-D-7, and Tank C-2 concentrators. The captured UNH droplets coalesce and drain by gravity seal loop to Tank C-7. The diversion of entrained UNH from the concentrator offgas to the UNH recycle system will greatly reduce the amount of uranium and other nonvolatiles in the effluents from the E-D-3 condenser, including process condensate stream to the 216-U-17 $\mathrm{Crib}$ and the process offgas to $296-U-4$. 
Figure 4. Design of the Waste Stream in the $\mathrm{UO}_{3} \mathrm{Plant}$ Crib.

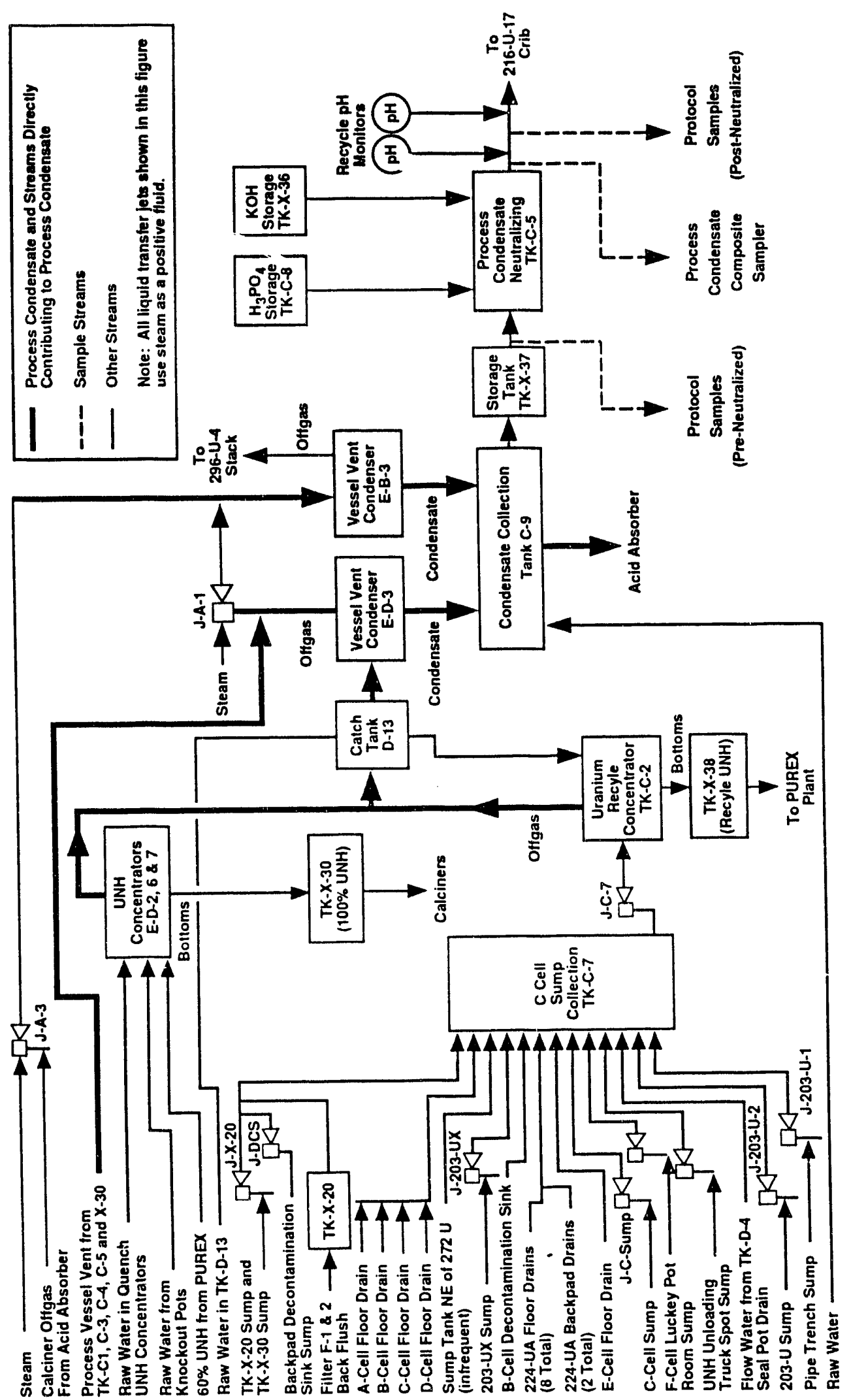


Figure 5. Flow Sheet of Contributors to the Process Condensate. ( $D-D-1$ is a fiber mist el iminator)

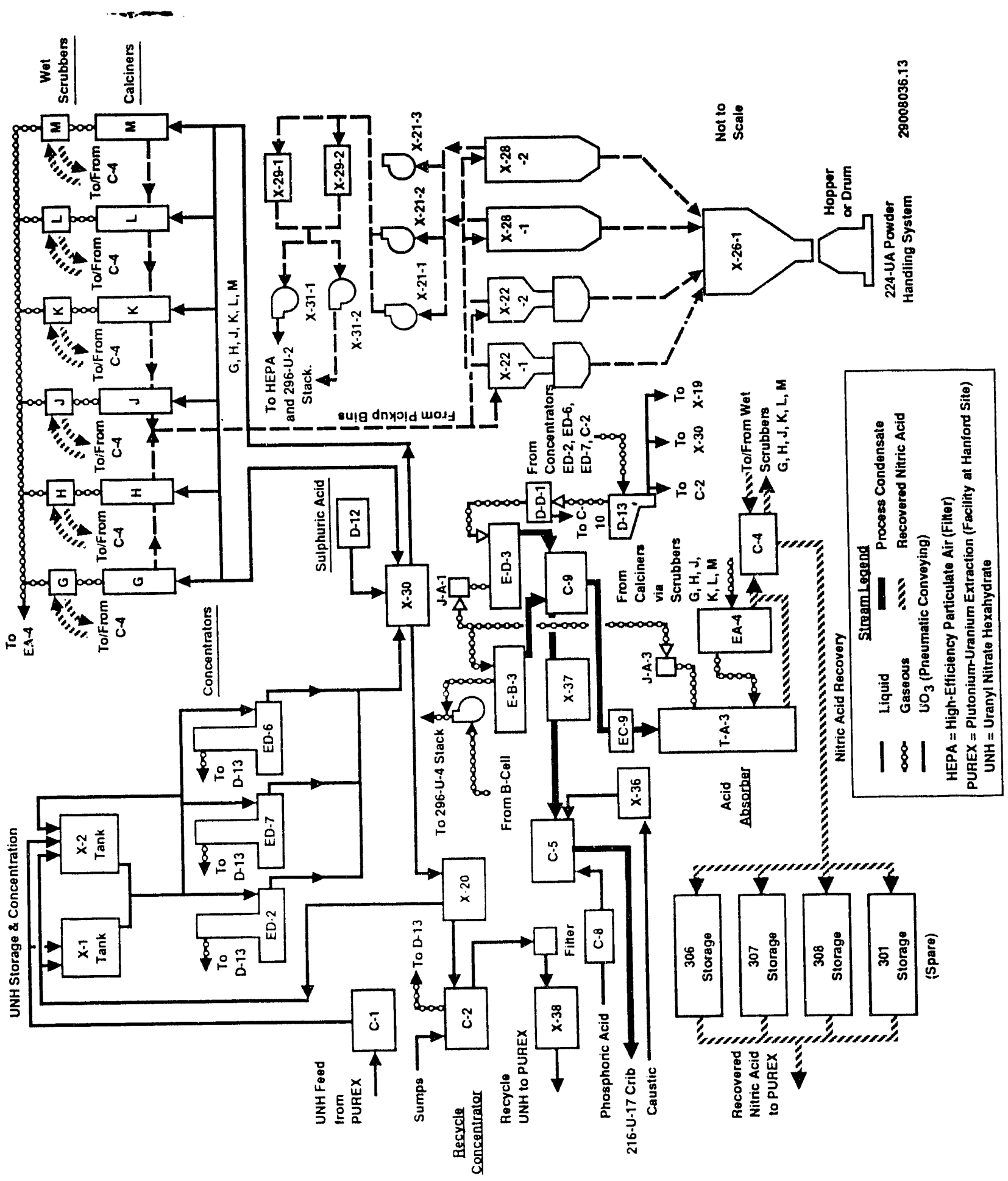


Table 1. Contributors to $\mathrm{UO}_{3}$ Plant Process Condensate.

\begin{tabular}{|c|c|c|}
\hline Contributor stream & Pathway into condensate & Operating modes \\
\hline $\begin{array}{l}\text { Feed uranyl nitrate } \\
\text { hexahydrate } \\
\text { concentrator offgas }\end{array}$ & $\begin{array}{l}\text { Evaporation in concentrators } \\
E-D-6, E-D-7 \text {, and } / \text { or } E-D-2 \text {, and } \\
\text { condensation in } E-D-3 \text { and } E-B-3\end{array}$ & Calcination only \\
\hline Calciner offgas & $\begin{array}{l}\text { Sprayed with nitric acid in } \\
224-U A \text { wet scrubbers, condensed } \\
\text { in E-A-4 (condensate routed to } \\
\text { recovered nitric acid tank), } \\
\text { passes through T-A-3 nitric } \\
\text { acid scrubber, condensed in } \\
\text { E-B-3 }\end{array}$ & Calcination only \\
\hline $\begin{array}{l}\text { Recycle uranyl } \\
\text { nitrate hexahydrate } \\
\text { concentrator offgas }\end{array}$ & $\begin{array}{l}\text { Evaporation in Tank } C-2 \text {, and } \\
\text { condensation in } E-D-3 \text { and } E-B-3\end{array}$ & $\begin{array}{l}\text { Calcination and } \\
\text { standby }\end{array}$ \\
\hline $\begin{array}{l}\text { Steam from } \\
284-W \text { Powerhouse }\end{array}$ & $\begin{array}{l}\text { Motive fluid in } J-A-1 \text { and } J-A-3 \\
\text { offgas jets; condensed in } E-D-3 \\
\text { and } E-B-3\end{array}$ & $\begin{array}{l}\text { Calcination and } \\
\text { standby }\end{array}$ \\
\hline $\begin{array}{l}\text { Fumes from } \\
\text { miscellaneous } \\
\text { process vessel vents }\end{array}$ & $\begin{array}{l}\text { Swept from tank vapor space by } \\
\text { vessel ventilation system and } \\
\text { condensed in E-B-3 }\end{array}$ & $\begin{array}{l}\text { Calcination and } \\
\text { standby }\end{array}$ \\
\hline Raw water & $\begin{array}{l}\text { Added to Tank } C-9 \text {, to provide } \\
\text { scrub water for nitric acid } \\
\text { absorber when concentrators not } \\
\text { in operation }\end{array}$ & Calcination only \\
\hline Phosphoric acid & $\begin{array}{l}\text { Pumped from } \mathrm{C}-8 \text { tank into } \\
\text { neutralization tank } \mathrm{C}-5 \text { to } \\
\text { immobilize uranium and for } \mathrm{pH} \\
\text { buffering }\end{array}$ & $\begin{array}{l}\text { Calcination and } \\
\text { standby }\end{array}$ \\
\hline Potassium hydroxide & $\begin{array}{l}\text { Pumped from } X-36 \text { tank into } \\
\text { neutral ization tank } C-5 \text { for } \\
\text { elementary neutralization }\end{array}$ & $\begin{array}{l}\text { Calcination and } \\
\text { standby }\end{array}$ \\
\hline
\end{tabular}

\subsection{Feed Uranyl Nitrate Hexahydrate Concentrator Offgas}

Condensate. A $60 \%$ UNH feedstock from the PUREX Facility is boiled in the steam-heated E-D-2, E-D-6, and E-D-7 concentrators to produce $100 \%$ UNH. The concentrated $100 \%$ UNH bottoms overflow continuously to Tank $X-30$ for additional processing at the 224-UA Building. The J-A-1 offgas jet draws water vapor and other volatiles evolved by the tank to the E-D-3 condenser. Water vapor and any other condensibles present in the concentrator offgas drop out in the E-D-3 condenser and drain into Tank C-9. The J-A-1 jet discharges 
the offgas from the E-D-3 condenser to the E-B-3 condenser, where the steam used by the jet is condensed along with any remaining condensibles.

3.1.1.1.2 Calciner offgas Condensate. The electrically heated $\mathrm{UO}_{3} \mathrm{Pl}$ ant calciners convert $100 \%$ UNH to $\mathrm{UO}_{3}$ powder, offgassing mostly water vapor and oxides of nitrogen. The calciner offgas is scrubbed with recovered nitric acid in the 224-UA wet scrubbers to dissolve any entrained UNH particles. The calciner offgas then passes through the E-A-4 condenser, which removes most of the water vapor from the stream. The condensate from E-A-4 drains to the Tank $\mathrm{C}-4$. The remaining calciner offgas is drawn through the 20 bubble cap trays of the T-A-3 nitric acid absorber by the J-A-3 offgas jet. Process condensate from Tank $C-9$ scrubs the calciner offgas in $T-A-3$, and removes virtually all of the uranium-bearing mists and most of the NOX from the calciner offgas. The remaining calciner offgas exits $T-A-3$, is mixed with steam from $J-A-3$ and $J-A-1$, and passes through the E-B-3 condenser. Condensibles drain from E-B-3 to Tank C-9.

\subsection{Recycle Uranyl Nitrate Hexahydrate Concentrator Offgas} Condensate. Potentially uranium-bearing flush solutions, decontamination solutions, and rainwater from sumps throughout the 203-U and 224-UA Buildings, the backpad area, and the 224-U process cells are boiled off in the steamheated Tank C-2 recycle UNH concentrator. This operation minimizes the potential for contamination spread and discharge of uranium to the soil column, and was used to recycle uranium in the PUREX Facility. The nonvolatile bottoms accumulate in Tank $\mathrm{C}-2$ until the UNH concentration was high enough to warrant filtration and recycle to the PUREX Facility via Tank $\mathrm{X}-38$. The J-A-1 offgas jet draws water vapor and other volatiles evolved from the recycle concentrator through the concentrator offgas header and the D-13 surge tank to the E-D-3 condenser. Water vapor and other condensibles present in the recycle concentrator offgas drop out in E-D-3 and drain to Tank $C-9$. The $\mathrm{J}-\mathrm{A}-1$ jet discharges the offgas from the E-D-3 condenser to the $E-B-3$ condenser, where the steam used by the jet is condensed along with any remaining condensibles. Condensate from E-B-3 also drains to Tank C-9.

\subsection{4-W Powerhouse Steam Condensate. Steam from the} 284-W Powerhouse provides fluid for process offgas jets $\mathrm{J}-\mathrm{A}-1$ and $\mathrm{J}-\mathrm{A}-3$. Steam used by the jets passes through the E-B-3 condenser, from which condensate drains to Tank C-9.

3.1.1.1.5 Miscellaneous Process Vessel Vent Condensate. Many of the process vessels in the 224-U Building are vented by the process vessel vent system. These vessels include UNH storage tanks, nitric acid storage tanks, and the process condensate neutralization tank. Vapors are drawn from these vessels by the J-A-1 jet and discharged to the E-B-3 condenser, from which condensate drains to Tank $C-9$. Alternatively, the process vessel vent system can be routed to the $E-B-3$ condenser via the $E-A-4$ calciner offgas condenser, T-A-3 nitric acid absorber, and J-A-3 to the E-B-3 condenser.

3.1.1.2 Contribution from Raw Water. During calcination, a portion of the process condensate in Tank $\mathrm{C}-9$ is re-used as reflux scrubbing water in the T-A-3 nitric acid absorber. When condensate generation rates are too low to operate the nitric acid absorber, raw water is added to Tank C-9 to ensure an uninterrupted supply of scrub water. This occurs mainly when, in preparation for a weekend shutdown, the feed UNH concentrators are shut down, and the calciners continue to work off the $100 \%$ UNH inventory in Tarik $X-30$. 
3.1.1.2.1 Phosphoric Acid and Potassium Hydroxide Addition to Process Condensate. From Tank $C-9$, the process condensate overflows to a $52,996-\mathrm{L}$ $(14,000-g a 1)$ surge tank, $X-37$. Any excess raw water added to Tank $C-9$ to support acid absorber operation al so overflows to Tank $X-37$. From Tank $X-37$, condensate is pumped batchwise to Tank $C-5$, buffered with phosphoric acid, neutralized with potassium hydroxide, and discharged to the 216-U-17 Crib. The amounts of these contributors added to the process condensate are controlled by the process condensate neutralization system, as discussed in Appendix A, Section Al.2.1.

\subsection{PROCESS OPERATION}

The $\mathrm{UO}_{3} \mathrm{Pl}$ ant has two principal operating modes: standby and calcination. The $\mathrm{UO}_{3} \mathrm{Pl}$ ant produces $\mathrm{UO}_{3}$ during a UNH calcination mode. Process condensate neutralization is performed, as needed, to eliminate the corrosive aspect of acidic waste generated Juring both operating modes. These processing activities are described in Appendix $A$.

\subsection{PROCESS DATA}

The constituents of each contributor to the $\mathrm{UO}_{3} \mathrm{Plant}$ process condensate are discussed in this section. The only contributors that directly enter the process condensate are steam from the 284-W powerhouse, raw water, and neutralization chemicals $\left(\mathrm{H}_{3} \mathrm{PO}_{4}\right.$ and potassium hydroxide). All other contributors are either evaporated in one of the concentrators or pass through the nitric acid recovery system before condensing and joining the process condensate stream. Most of the contributors to the process condensate are acidic. The process condensate neutralization system automatically neutralizes condensate to prevent corrosive discharges to the 216-U-17 Crib. Sampling and monitoring is performed downstream of any contributors to the stream to confirm that the discharge is not corrosive.

\subsubsection{Discharge Rates}

The volume of condensate generated varies greatly according to the operating mode. For process condensate discharged to the 216-U-17 Crib, "old data" are used. Because the plant has only operated once during data collection and changeover to the 216-U-17 Crib, the only calcination mode data set available is from the February 6, 1989 sampling. The 216-U-17 Crib operated between January 1988 and June 1989 before the current operation. Total discharge during this time was $2,109,173 \mathrm{~L}(557,200$ gal) of effluent. During 1988, 722,422 L (190,849 gal) were discharged and during 1989 $1,386,751 \mathrm{~L}(366,351 \mathrm{gal})$ were discharged to the crib. The flow rate is shown diagrammatically in Figure 6 . In 5 days of calcination mode operation, $2.14 \times 10^{5} \mathrm{~L}$ of process condensate were produced. The monthly calcination mode process condensate generation rate is estimated to be $9.18 \times 10^{5} \mathrm{~L} / \mathrm{month}$, based on 5 calcination days per week and a 30-day month. Table 2 summarizes the process condensate generation rate data for both calcination and standby mode. 
WHC-EP-0664

Figure 6. Flow Rate 1988-1989.

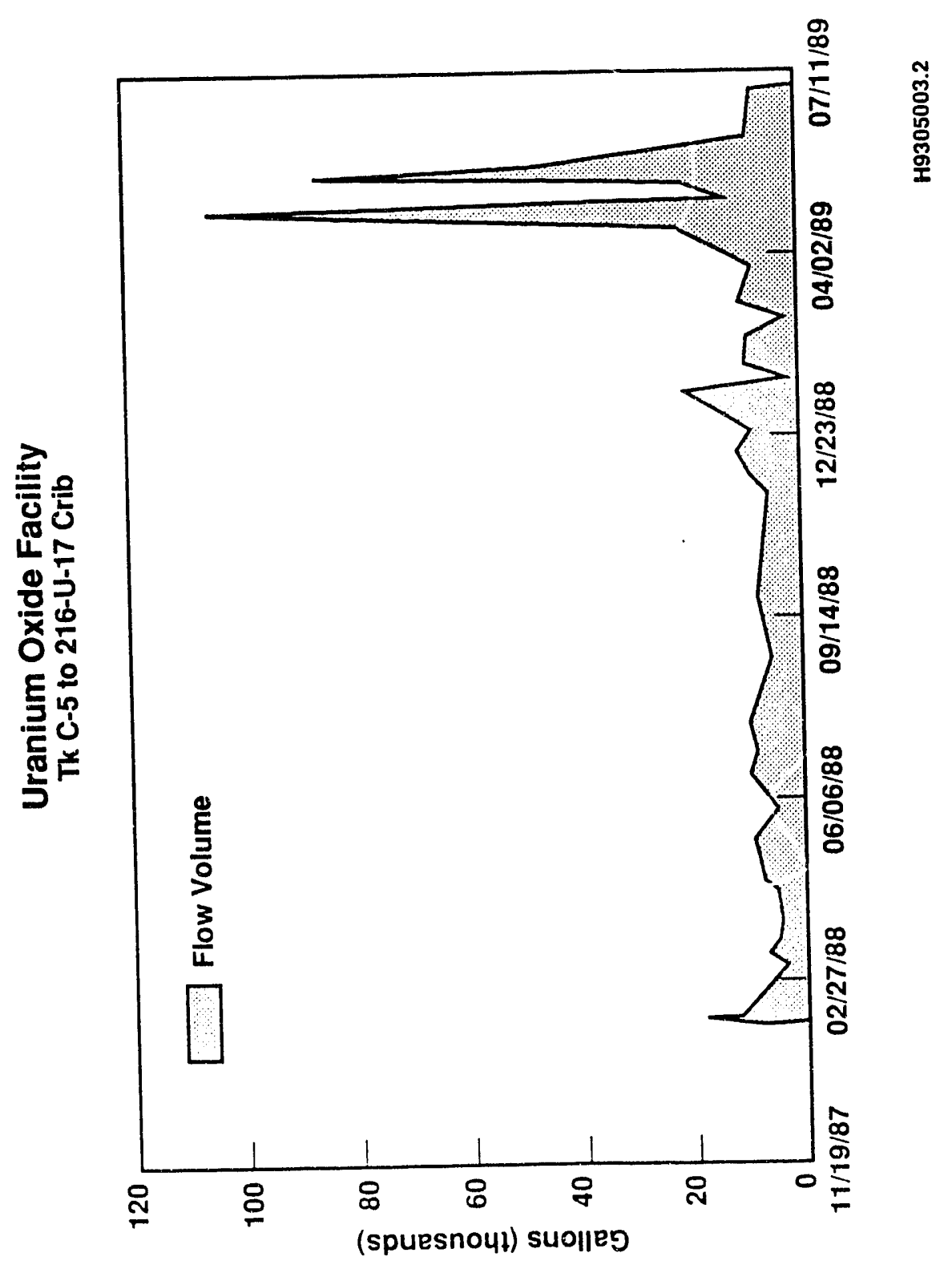


Table 2. Process Condensate Generation Rates 1988.

\begin{tabular}{|c|c|c|c|}
\hline \multicolumn{2}{|c|}{ Standby operating mode } & \multicolumn{2}{|c|}{ Calcination operating mode } \\
\hline Month & Liters & Montí & Liters \\
\hline $3 / 88$ & $4.32 E+04$ & $\begin{array}{c}2 / 1-6 / 88 \\
\text { (Only five calcination mode } \\
\text { days during this period) }\end{array}$ & $2.14 E+05$ \\
\hline $5 / 88$ & $5.63 E+04$ & - & -- \\
\hline $6 / 88$ & $6.21 E+04$ & -- & - \\
\hline $8 / 88$ & $3.95 E+04$ & -- & -- \\
\hline $\begin{array}{c}\text { Average monthly } \\
\text { volume }\end{array}$ & $5.03 E+04$ & $\begin{array}{l}\text { (Extrapolated for 30-day } \\
\text { month, calcining } \\
5 \text { days/week) }\end{array}$ & $9.18 E+05$ \\
\hline
\end{tabular}

Discharge to the 216-U-17 Crib resumed in August 1992. The volume through February 1993 is $1.12 \times 10^{6} \mathrm{~L}(295,881$ gal). The projected volume until termination in 1995 is shown in Figure 7 and 1 isted in Table 3.

\subsection{EFFLUENT CONSTITUENTS}

The effluent discharged to $216-U-i 7$ Crib has been designated as "nondangerous, radioactive" (WHC 1990a, Table 3-1; Tyler 1991). The radioactive constituents, summarized on a monthly basis for 1988 and 1989, are listed in Table 4. The nonradioactive constituents were summarized in WHC 1990a (Table 2.21-2) and by Tyler (1991), and are reproduced in Table 5. This table is based on pre-1988 data and may overstate the characteristics of the process condensate that was discharged to the 216-U-17 Crib during this time interval. Geophysical logging of the two vadose zone boreholes and one groundwater monitoring borehole (Appendix B) has not identified any detectable radionuclides in the soil column at the 216-U-17 Crib site.

The forecast of effluent concentrations for the 216-U-17 Crib are summarized in Table 6 .

\subsection{CONSTITUENTS OF INTEREST}

The $\mathrm{UO}_{3}$ Plant process condensate, which is neutralized to near $\mathrm{pH} 7$ before transfer to the crib, contains low concentrations of uranium, nitrate, ${ }^{99} \mathrm{Tc}$, and fluoride. In addition, copper and zinc have been detected in the groundwater above background levels (Johnson 1993). 
Figure 7. Projected Volume of Effluent Until 1995.

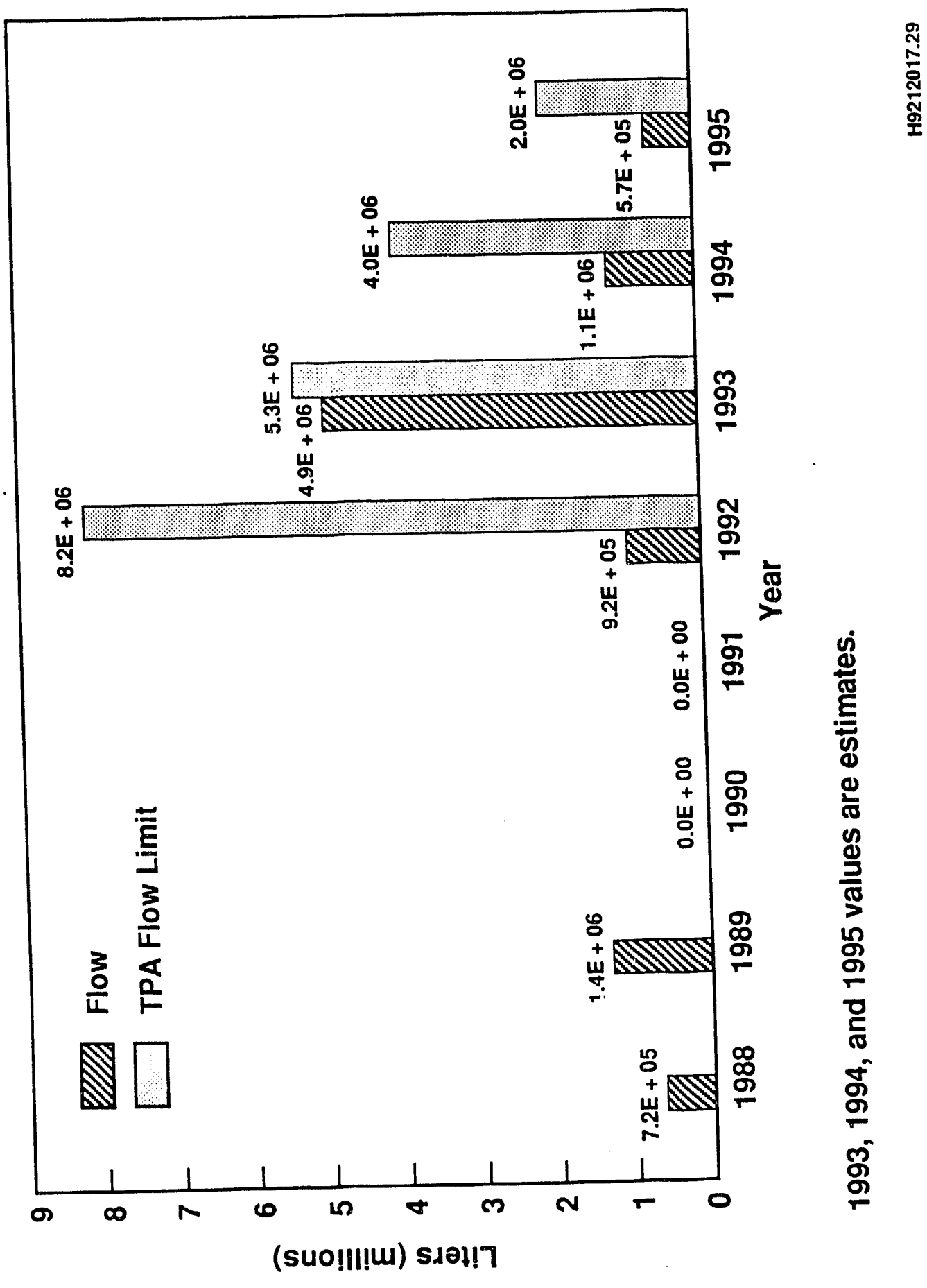


Table 3. Projected Volume of Discharge to 216-U-17 Crib.

\begin{tabular}{|c|c|c|}
\hline Year & $\begin{array}{c}\text { Tri-Party Agreement } \\
\text { flow limit (1iters) }\end{array}$ & $\begin{array}{c}\text { Planned flow } \\
\text { (1iters) }\end{array}$ \\
\hline 1992 & 8.2 E+06 & 9.3 E+05 \\
\hline 1993 & $5.3 E+06$ & $4.9 E+06$ \\
\hline 1994 & $4.0 E+06$ & $1.1 E+06$ \\
\hline 1995 & $2.0 E+06$ & $2.0 E+06$ \\
\hline
\end{tabular}

${ }^{8}$ Ecology, EPA, and DOE, 1990, Hanford Federal Facility Agreement and Consent Order, Washington State Department of Ecoloyy, U.S. Environmental Protection Agency, and U.S. Department of Energy, Olympia, Washington. A1so referred to as the Tri-Party Agreement.

The primary constituents of interest in the process condensate are uranium, ${ }^{99} \mathrm{Tc}$, nitrate, and fluoride. Technetium-99 is of principal concern because it is highly soluble and is not retarded by the soil column, and generally moves unhindered along with water. Lower levels of chromium, mercury, acetone, and ${ }^{90} \mathrm{Sr}$ were detected (see Table 5) and discharged to other cribs but were not detected in previous runs to the 216-U-17 Crib.

As an addition to this report following the initial results on constituents obtained from the present run in June 1993 (see Section 5.4), the new analyses suggest that the data 1 isted in Table 4 are comparable with these more detailed analyses now being cbtained. 


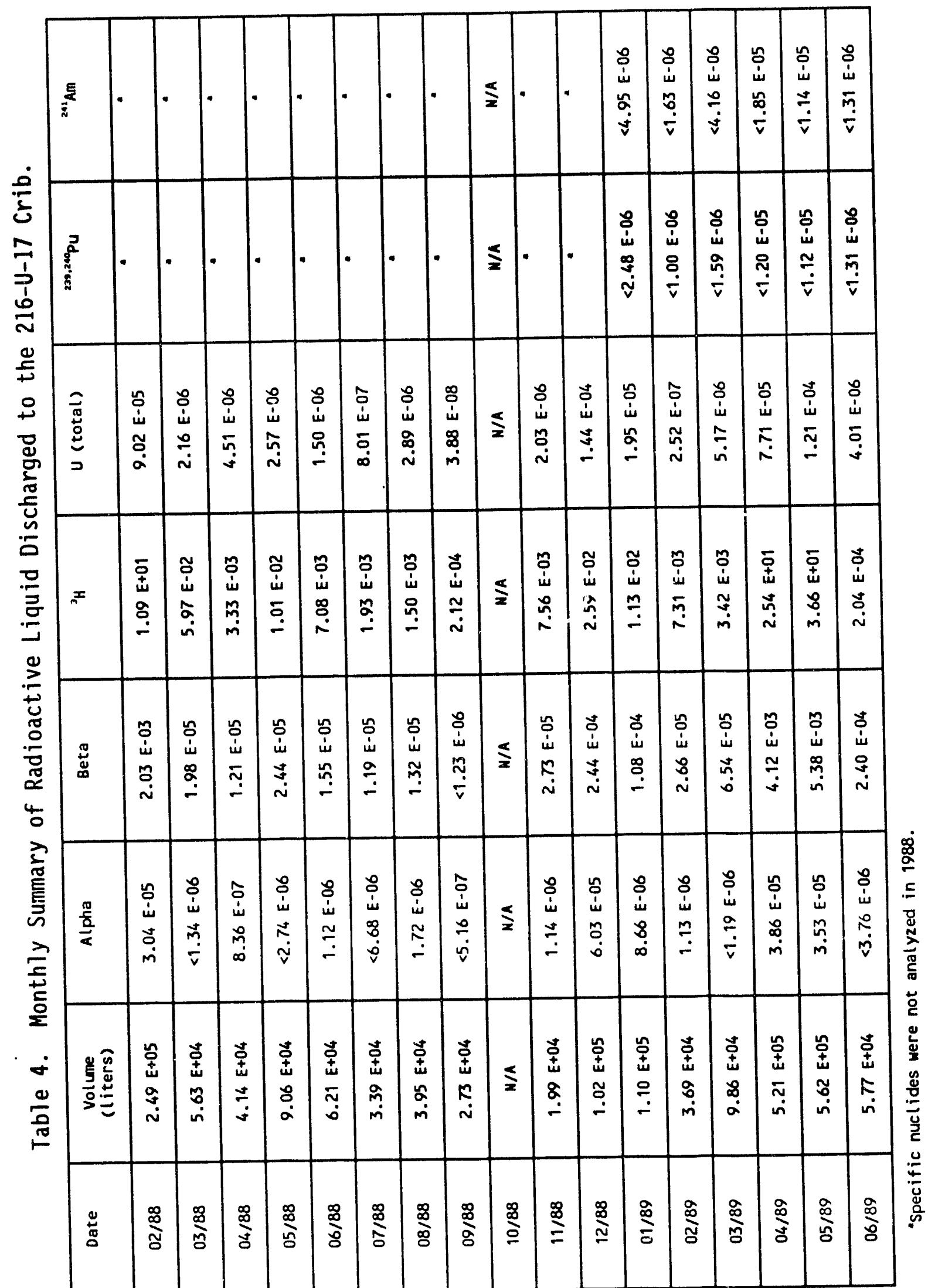


WHC-EP-0664

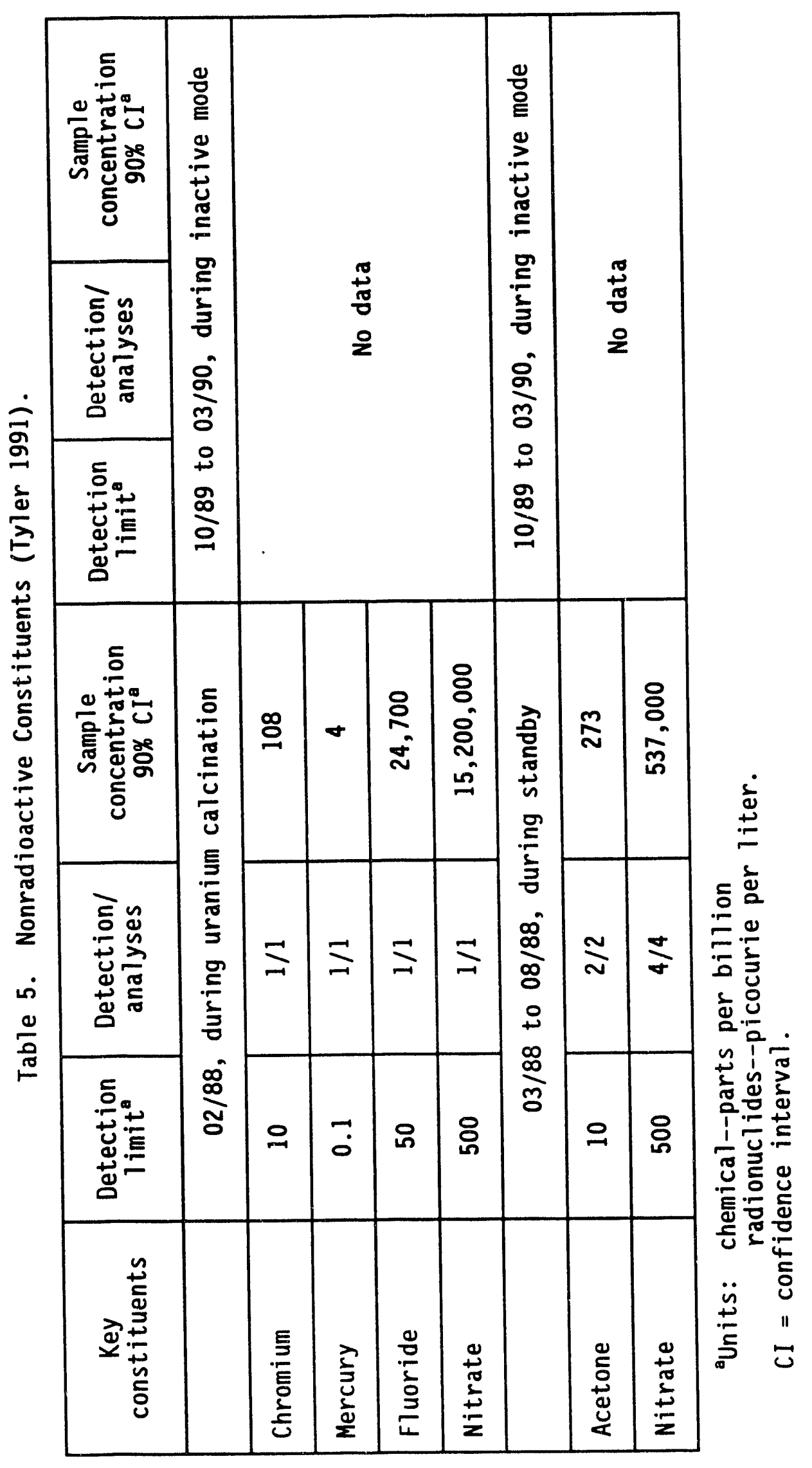


WHC-EP-0664

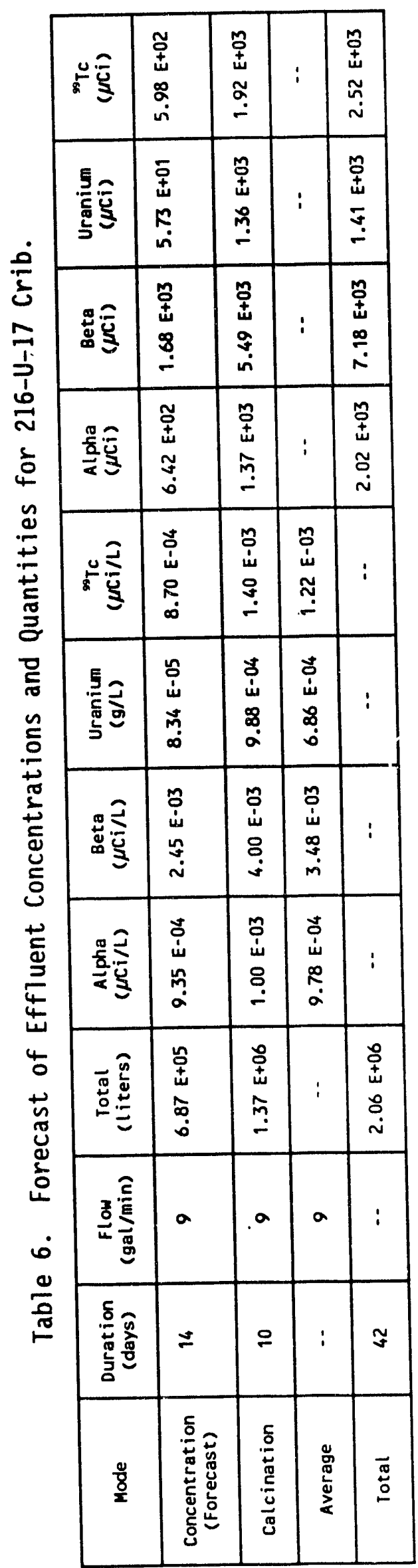


WHC-EP-US554

This page intentionally left blank. 


\subsection{GEOHYDROLOGY AND CONCEPTUAL MODEL OF THE 216-U-17 CRIB}

\subsection{GEOHYDROLOGY OF THE HANFORD SITE}

The Hanford Site is located in the Pasco Basin, a broad alluvial basin within the Columbia Plateau (Figure 8). The geology and hydrology of the Pasco Basin and fianford Site have been discussed in numerous reports (i.e., Delaney et al. 1991; DOE 1987; DOE 1988; Gephart et al. 1979; Lindsey 1991; Myers et a1. 1979; Myers and Price 1981; and Reidel and Hooper 1989). The reader is referred to these reports for detailed descriptions.

The geohydrology of the 200 West Area has been the subject of much study and many reports over the past several decades (i.e., Gephart et a1. 1979; Graham et a1. 1981; Myers et 21. 1979; Myers and Price 1981; Routson and Johnson 1990; and Tallman et al. 1979). The most recent work on the 200 West Area geology is by Lindsey et al. (1991).

The 200 Areas lie on the north limb of the Cold Creek syncline. The uppermost flow of the Columbia River Basalt Group (CRBG) is the Elephant Mountain Member (Figure 9). The suprabasalt stratigraphy consists of the Ringold Formation, the Plio-Pleistocene unit, the early "Palouse" soil, and the Hanford formation.

The hydrogeology of the Hanford Site is characterized ty a multiaquifer system that consists of four hydrogeologic units that correspond to the upper three formations of the CRBG (Grande Ronde Basalt, Wanapum Basalt, and Saddle Mountains Basalt) and the suprabasalt sediments (see Figure 9 ). The basalt aquifers consist of the CRBG and relatively minor amounts of intercalated fluvial and volcaniclastic sediments of the Ellensburg Formation. The uppermost aquifer system, the unconfined aquifer, consists of fluvial, lacustrine, and glaciofluvial sediments. This aquifer is contained largely within the Ringold Formation and Hanford formation.

The base of the uppermost aquifer system is defined as the top of the uppermost basalt flow. However, fine-grained overbank and lacustrine deposits in the Ringold Formation locally form confining layers for Ringold fluvial gravels underlying unit $E$ (Figure 10). The uppermost aquifer system is bounded laterally by anticlinal basalt ridges and is approximately $152.4 \mathrm{~m}$ $(500 \mathrm{ft})$ thick near the center of the Pasco Basin.

Sources of natural recharge to the uppermost aquifer system are rainfall and runoff from the higher bordering elevations, water infiltrating from smali ephemeral streams, and river water along influent reaches of the Yakima and Columbia Rivers. The movement of precipitation through the unsaturated (vadose) zone has been studied at several locations on the Hanford Site (Gee 1987; Rockhold et a1. 1988; Routson and Johnson 1990). Conclusions from these studies vary. Gee (1987) and Routson and Johnson (1990) concluded that little if any downward percolation of precipitation occurs at undisturbed sites on the 200 Area Platiau where the sediments are layered and vary in texture, and that moisture penetrating the soil is removed by

evapotranspiration. 
Figure 8. Location Map of the Hanford Site and the Pasco Basin.

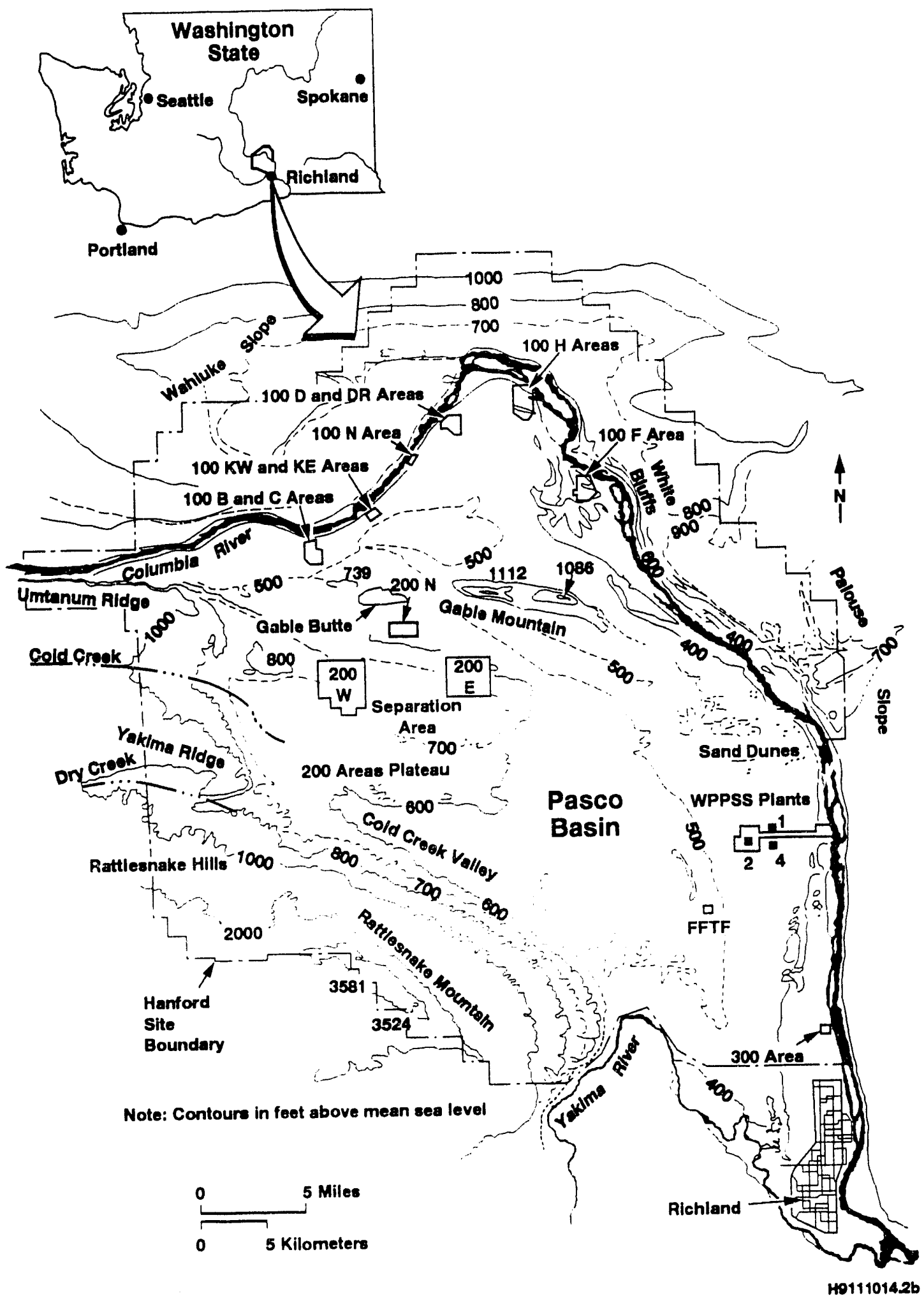


Figure 9. Stratigraphic Nomenclature of the Hanford Site.

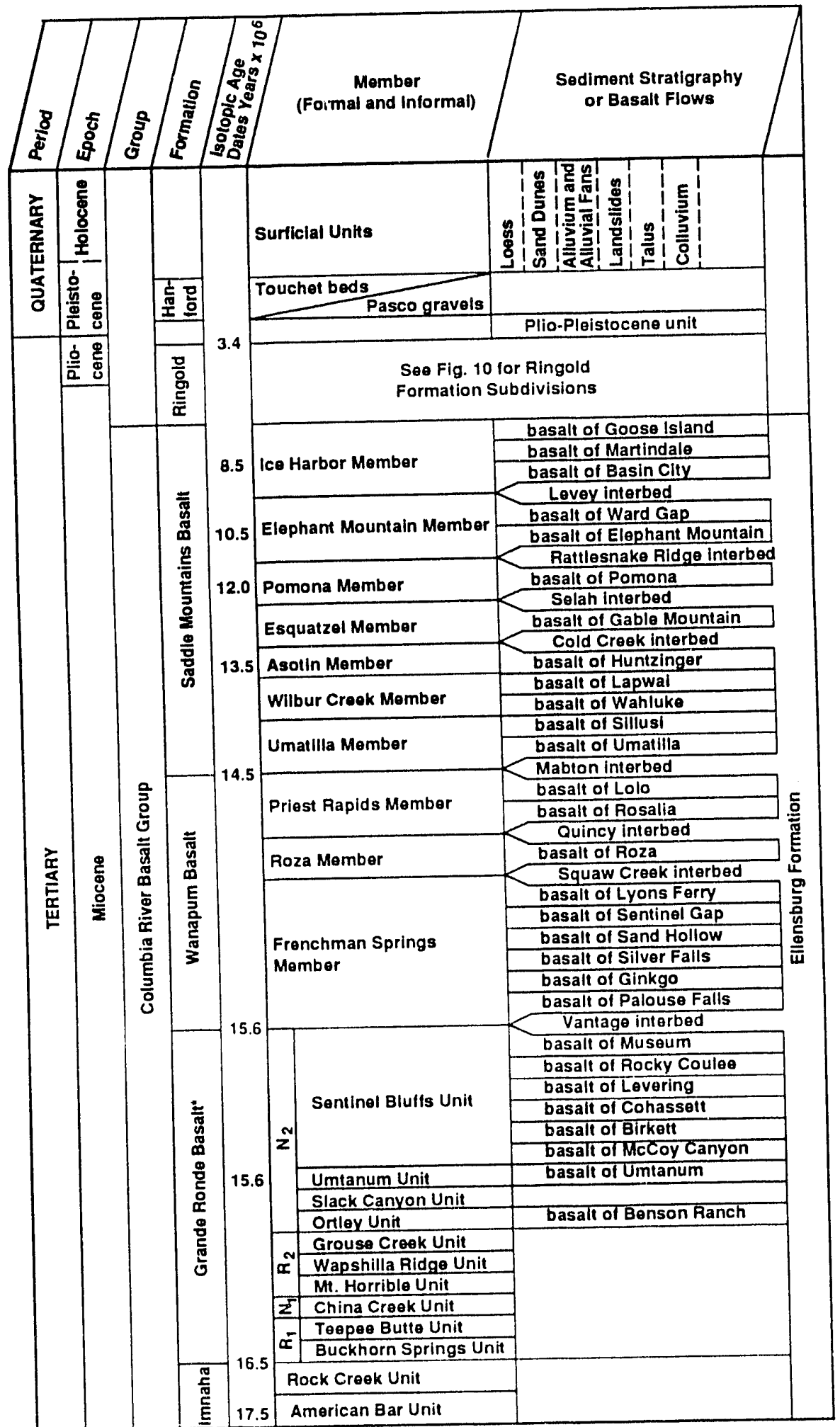

- The Grande Ronde Basalt consists of at least 120 major basalt llows. Only a few flows have been named. $N_{2}, R_{2}, N_{1}$ and $R_{1}$ are magnetostratigraphic units. 
Figure 10. Generalized Stratigraphy for the Hanford Site Showing the Relationship Between Units.

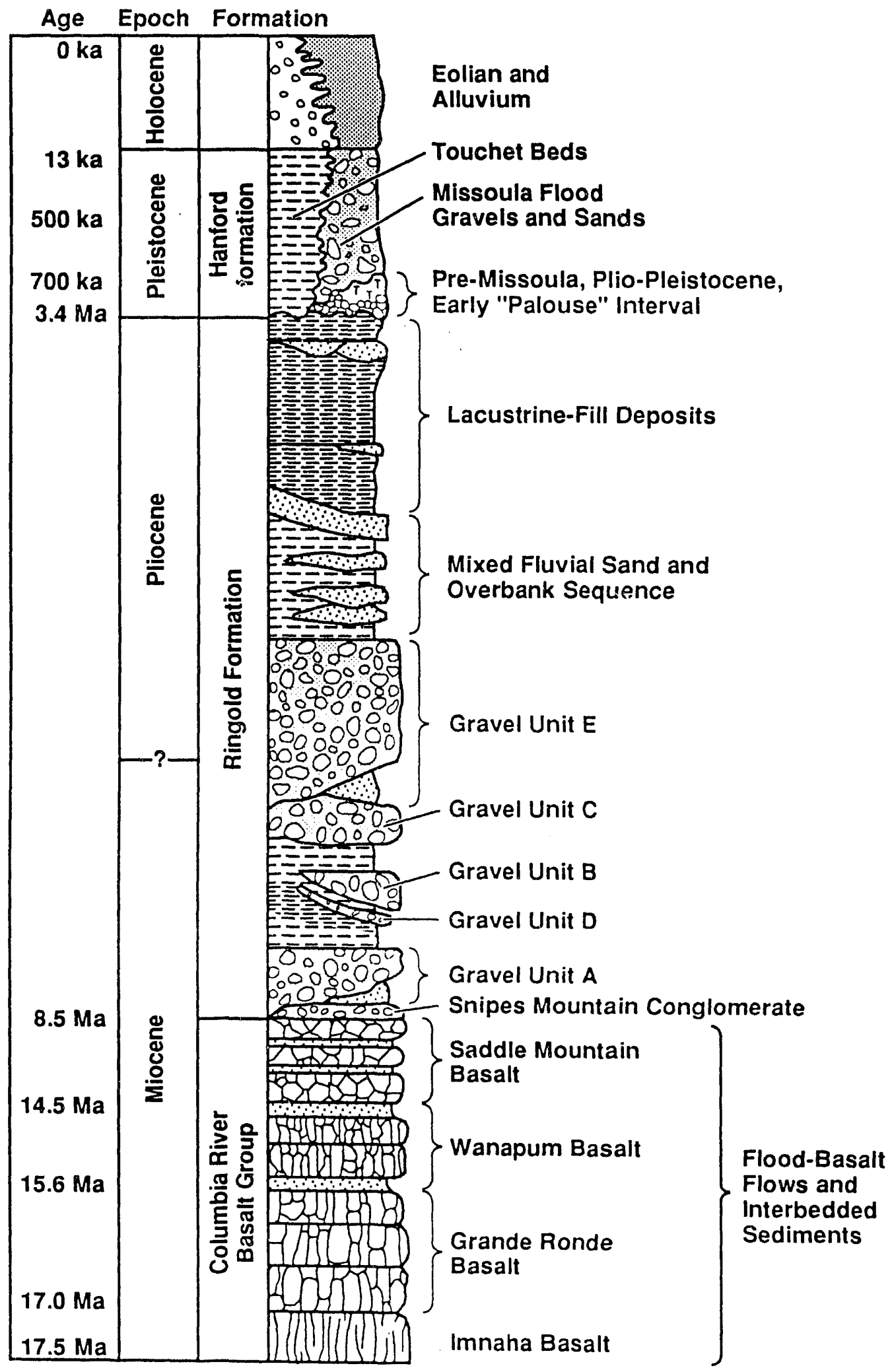

H9210011.1b 


\subsection{WEST AREA HYDROGEOLOGY}

The main near-surface hydrostratigraphic units in the 200 West Area and 216-U-17 Crib are (1) the Rattlesnake Ridge interbed, (2) the Elephant Mountain Member, (3) the Ringold Formation, (4) the Plio-Pleistocene unit and early "Palouse" soil, and (5) the Hanford formation (see Figures 9 and 10).

The uppermost regionally extensive aquifer beneath 200 West Area consists of the Rattlesnake Ridge interbed, the overlying flow bottom of the Elephant Mountain Member, and the underlying flow top of the Pomona Member. The Rattlesnake Ridge interbed consists of a clayey basalt conglomerate, an epiblastic fluvial-floodplain unit, an air-fall tuff, and a tuffite derived from fluvial reworking of the tuff and detrital sediments (Graham et a1. 1984; Reidel and Fecht 1981). The interbed is 50 to $82 \mathrm{ft}(15.2$ to $25 \mathrm{~m})$ thick beneath 200 West Area and generally thickens toward the west (Reidel and Fecht 1981). Recharge to the Rattlesnake Ridge interbed aquifer occurs in the higher elevations surrounding the Pasco Basin to the west, north, and northeast. The flow of groundwater is generally toward the northeast beneath the 200 West Area (Figure 11) and west to west-northwest beneath the 200 East Area. Graham et al. $(1981,1984)$ reported transmissivity values of 2.4 to $355.1 \mathrm{~m}^{2} /$ day ( 8 to $1,165 \mathrm{ft}^{2} /$ day) over the entire thickness of the aquifer.

Beneath the 200 West Area the Rattlesnake Ridge interbed aquifer is separated from the overlying uppermost aquifer system by the Elephant Mountain Member. The Elephant Mountain Member is up to $35 \mathrm{~m}(115 \mathrm{ft})$ thick and divided into two flow units separated by an interflow zone approximately $0.9 \mathrm{~m}(3 \mathrm{ft})$ thick that consists of interconnected vesicles and rubble zones (Reidel and Fecht 1981).

The uppermost aquifer system in the 200 West Area and $216-U-17 \mathrm{Crib}$ occurs primarily within the sediments of the Ringold Formation and Hanford formation. The upper aquifer is contained within the Ringold Formation and displays unconfined to locally confined or semiconfined conditions. The depth to groundwater in the upper aquifer underlying the former $U$ Pond in 200 West Area (see Figure 11) is approximately $57.9 \mathrm{~m}(190 \mathrm{ft})$. The saturated thickness of the unconfined aquifer is approximately 67.2 to $112.2 \mathrm{~m}$ (220 to $368 \mathrm{ft}$ ) in the 200 West Area.

The lower part of the upper aquifer system consists of Ringold unit $A$, and generally is confined by fine-grained sediments of the lower mud sequence (see Figure 10). The thickness of this confined zone ranges from greater than $15.2 \mathrm{~m}(50 \mathrm{ft})$ in the southern portion of the 200 West Area near the 216-U-17 Crib to less than $6.1 \mathrm{~m}(20 \mathrm{ft})$ beneath the northern portion of 200 West Area (Last et al. 1989). The lower mud sequence is absent in the northern portion of 200 West Area, and a single, undifferentiated grave 1 sequence consisting of unit $A$ and the overlying deposits of unit $E$ is found. In this area it is not possible to hydraulically differentiate units $A$ from $E$. The confining zone overlying unit $A$ is up to $21.3 \mathrm{~m}$ (70 ft) thick below the western section of 200 West Area before pinching out in the eastern section of the 200 West Area. A mean hydraulic conductivity of $1.6 \times 10^{-5} \mathrm{~m} /$ day $\left(5.19 \times 10^{-5} \mathrm{ft} /\right.$ day) has been obtained for these fines from permeameter testing of core samples from the top of the unit (Last et al. 1989). The upper part of the uppermost aquifer system in the 200 West Area is contained mostly within the fluvial gravel of unit $E$. Unit $E$ is more than $76.2 \mathrm{~m}$ 
7

Figure 11. Location of Water Disposal Ponds on the Hanford Site.

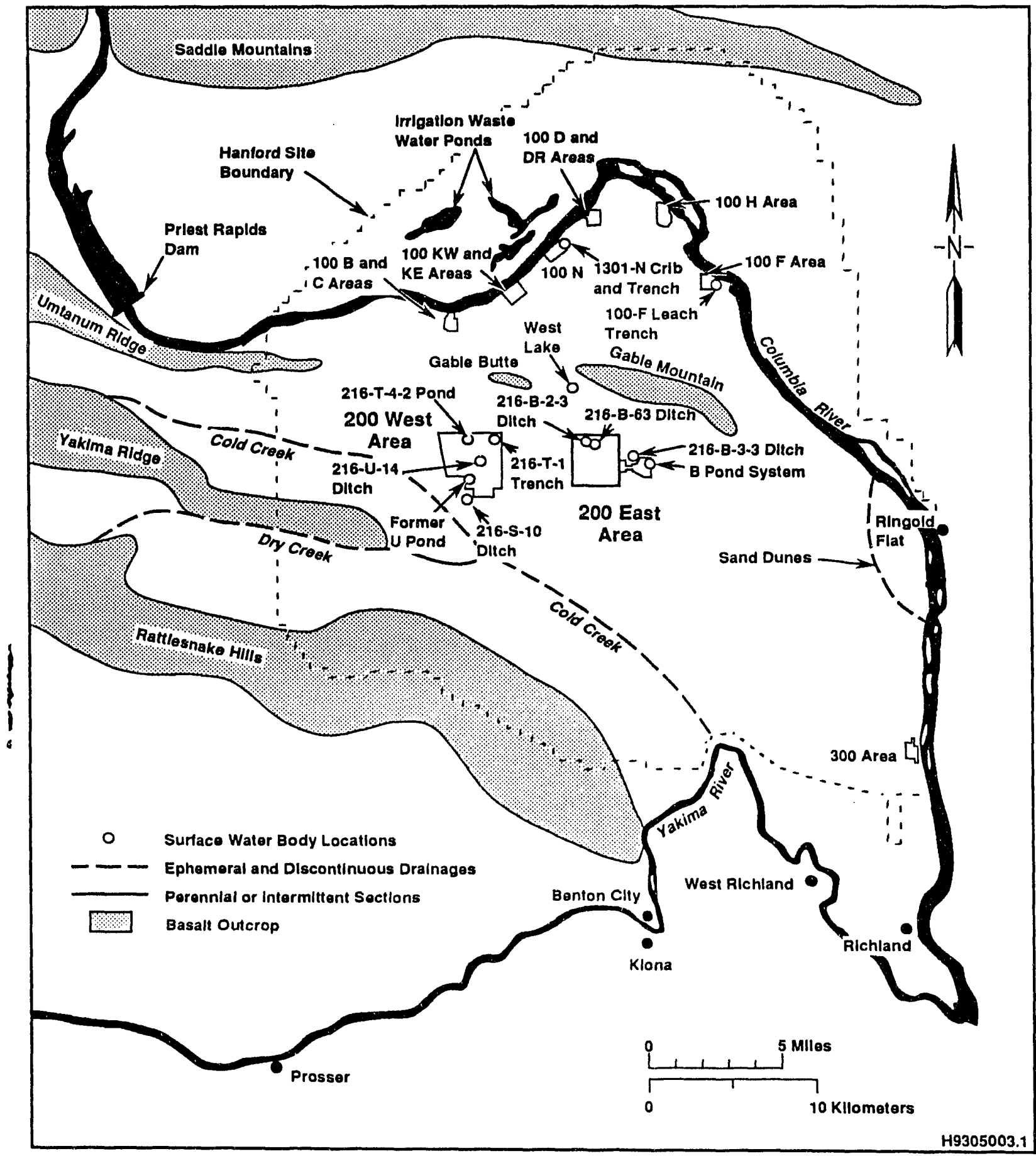


$(250 \mathrm{ft})$ thick in this area. Hydraulic conductivities range from 0.2 to $61 \mathrm{~m} /$ day $(0.06$ to $200 \mathrm{ft} /$ day) (Last et a1. 1989).

The vadose zone beneath the 200 West Area is approximately $54.9 \mathrm{~m}$ $(180 \mathrm{ft})$ beneath the former $U$ Pond. Sediments in the vadose zone consist of the (1) fluvial gravel of Ringold unit $E_{,}$(2) upper unit of the Ringold Formation, (3) Plio-Pleistocene unit, (4) early "Palouse" soil, and (5) Hanford formation (see Figure 10).

As much as $42.7 \mathrm{~m}$ (140 ft) of Ringold strata belonging to unit $E$ occurs above the water table in the 200 West Area. Pre-Hanford strata that overlie Ringold unit $E$ in the vadose zone are only found in the 200 West Area. These strata include: (1) fluvial sand and mud of the upper unit of the Ringold Formation, (2) pedogenic carbonates and alluvium of the PlioPleistocene unit, and (3) loess comprising the early "Palouse" soil. The upper unit of the Ringold Formation reaches a maximum thickness of $10.7 \mathrm{~m}$ (35 ft) and is most commonly encountered in the central, northern, and western parts of the 200 West Area. Pedogenic carbonate horizons of the PlioPleistocene unit are up to $10.7 \mathrm{~m}(35 \mathrm{ft})$ thick and overlie the Ringold Formation throughout most of the 200 West Area. The top of the PlioPleistocene unit dips approximately 1.5 degrees to the southwest beneath the 200 West Area. The high cementation and laterally continuous nature of this unit may create an interval with relatively low permeability. Thus a potential exists for lateral movement of vadose zone recharge water above the Plio-Pleistocene unit. Unconsolidated loess or sandy silt up to $4.6 \mathrm{~m}$ (15 ft) thick and designated the early "Palouse" soil overlies the Plio-Pleistocene unit beneath the southern portion of 200 West Area. This deposit is uniformiy fine grained, micaceous, and moderately calcium carbonate rich.

The Hanford formation is the uppermost unit in the unsaturated zone except for discontinuous recent eolian sands present in the northwestern section of the 200 West Area. Hanford formation sediments range from finegrained silty sands in the southern parts of 200 West Area to granule to boulder gravels in the northern part of 200 West Area. The Hanford formation is less than $6.1 \mathrm{~m}(20 \mathrm{ft})$ thick where the Plio-Pleistocene unit is near the surface (Last et a1. 1989) to more than $42.7 \mathrm{~m}(140 \mathrm{ft})$ thick. On the average, field moisture content of unsaturated Hanford formation sediments beneath the 200 West Area ranges from $2 \%$ to slightly greater than $6 \%$ (Last et a1. 1989).

Artificial recharge to the unconfined aquifer is estimated to be ten times greater than natural recharge (Graham et al. 1981). The major source of artificial recharge in the 200 West Area has been $U$ Pond (see Figure 11). A comparison of the hindcast water table map of the Hanford Site for 1944 and the present 200 Areas water table maps indicates that the natural water table elevation in the 200 West Area was approximately $19.8 \mathrm{~m}(65 \mathrm{ft})$ lower in 1944. The hindcast map indicates that the direction of regional flow was toward the east, and the natural hydraulic gradient was on the order of $0.3 \mathrm{~m} / 305 \mathrm{~m}(1 \mathrm{ft} / 1,000 \mathrm{ft})$ in the 200 West Area. The $U$ Pond, 1ocated in the 200 West Area, and Gable Mountain Pond, located north of the 200 East Area, were decommissioned in 1984 and 1987, respectively.

Groundwater elevations for December 1991 for the unconfined aquifer in the 200 Areas are shown in Figure 12. Groundwater flow beneath the 200 West Area is generally toward the north and the east, away from the mound created 
WHC-EP-0664

This page intentionally left blank. 


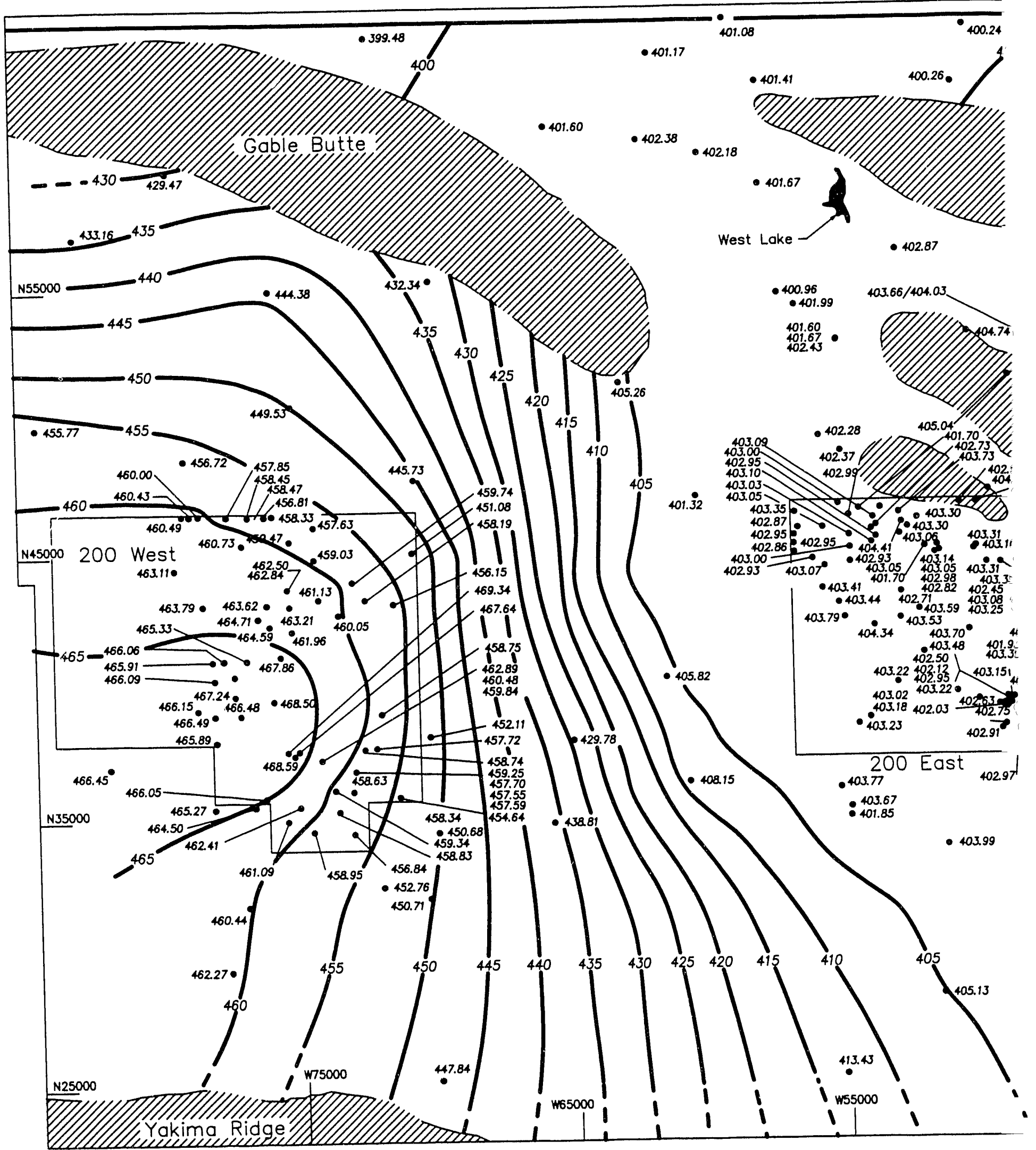




\section{Figure 12. 200 Areas Water Table Map, December 1991.}

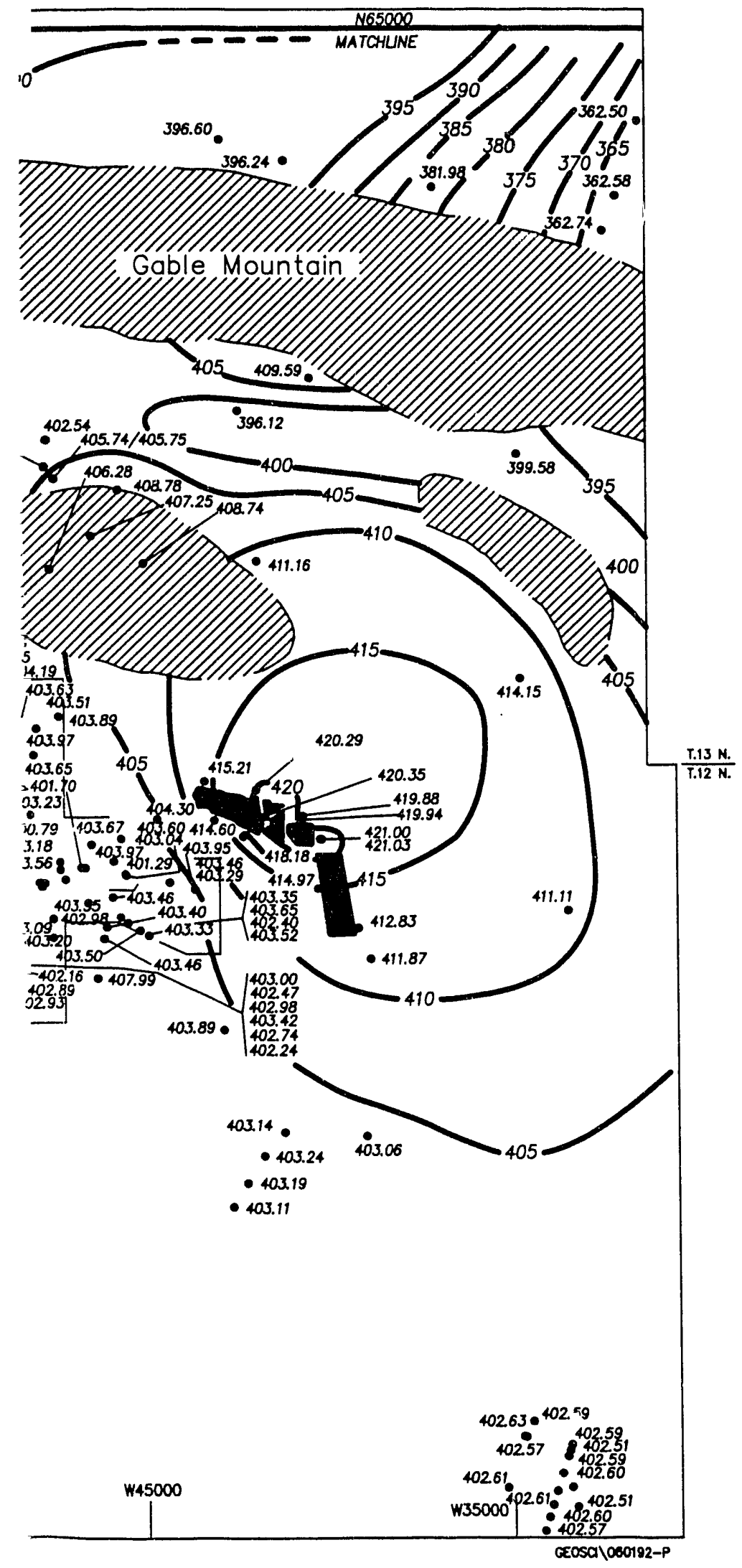

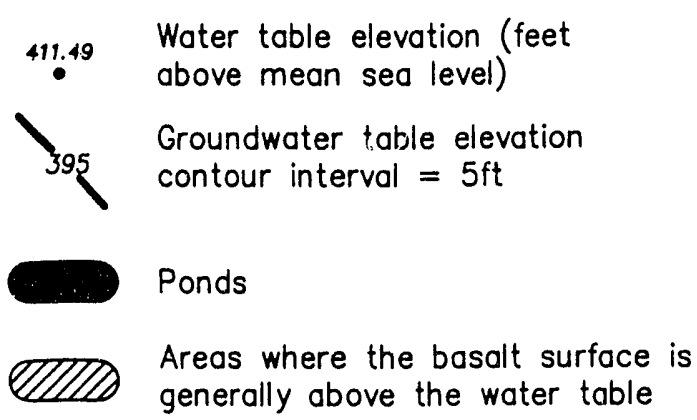

The 200 Areas water table elevation map has been prepared by the Geosciences Group. Environmental Division, of Westinghouse Hanford Company.

Note: To convert to metric, multiply elevation ( $\mathrm{ft}$ ) by 0.3048 to obtain elevation $(\mathrm{m})$.

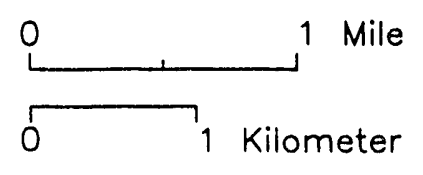


by past discharges to $U$ Pond. The horizontal hydraulic gradient is expected to decrease and shift to the east as the mound dissipates. The horizontal hydraulic gradient in the 200 West Area is relatively high, ranging from $1.2 \mathrm{~m} / 305 \mathrm{~m}$ ( $4 \mathrm{ft} / 1,000 \mathrm{ft}$ ) to $0.45 \mathrm{~m} / 305 \mathrm{~m}(1.5 \mathrm{ft} / 1,000 \mathrm{ft}$ ) (Graham et a1. 1981). The steep gradient is due to the presence of the water table exclusively in the Ringold Formation. Downward vertical hydraulic gradients are expected to be present within the unconfined aquifer in parts of the 200 West Area as a result of the $U$ Pond groundwater mound (Graham et a1. 1981). This has been confirmed by recent groundwater monitoring activity.

\subsection{6-U-17 CRIB SITE GEOHYDROLOGY}

\subsubsection{6-U-17 Crib Site Stratigraphy}

The stratigraphy in six groundwater monitoring wells at the 216-U-17 Crib site is shown in Figure 13. The relationship between the stratigraphy at the 216-U-17 Crib and the southern part of the 200 West Area is shown in Figures 14,15 , and 16 . These figures show that the stratigraphy at the 216-U-17 Crib is typical of the stratigraphy in the 200 West Area. No clastic dikes have been identified at the 216-U-17 Crib site.

\subsubsection{Site Geohydrologic Model}

A geohydrologic model for the 216-U-17 Crib site (Figure 17) was developed from the site-specific stratigraphy (see Figure 13) and the southern part of 200 West Area stratigraphy (see Figures 14, 15, and 16). This geohydrologic model contains 14 layers and forms the basis for the modeling discussed in Section 5.0. The water table occurs $63 \mathrm{~m}$ below the surface and has a slight gradient to the east. The description of the individual layers is as follows.

\begin{tabular}{|c|l|}
\hline Layer & \multicolumn{1}{|c|}{ Description } \\
\hline 1 & $\begin{array}{l}\text { Backfil1--Upper } 1.5 \mathrm{~m} \text { (5 ft) overlies gravel fill extending to } \\
\text { about } 6 \mathrm{~m}(20 \mathrm{ft}) .\end{array}$ \\
\hline $2-5$ & $\begin{array}{l}\text { Hanford formation, coarse-grained units--Approximately } 6 \text { to } 33 \mathrm{~m} \\
(20 \text { to } 110 \mathrm{ft}) .\end{array}$ \\
\hline 2 & $\begin{array}{l}\text { This is a medium- to coarse-grained sand that is typically we11 } \\
\text { bedded (horizontal beds with lesser cross-bedding) This includes } \\
\text { fine-grained sediments, if present, that usually form thin (<2 cm) } \\
\text { interbeds; the sands commonly are partially open framework } \\
\text { (abundant void space) containing little or no cement. } \\
\text { ing }\end{array}$ \\
\hline
\end{tabular}




\begin{tabular}{|c|c|}
\hline Layer & Description \\
\hline 3 & $\begin{array}{l}\text { A sandy gravel lense extends partly under the crib but pinches out } \\
\text { before borehole W19-24. This lense probably consists of several } \\
\text { gravel layers l to } 10 \mathrm{~cm} \text { thick (matrix suppurt common), as well as } \\
\text { sands with a few pebbles distributed throughout. Discontinuous } \\
\text { silt layers are probably present. Silt filling pore space in sands } \\
\text { and gravels is rare. }\end{array}$ \\
\hline 4 & Medium- to coarse-grained sand (same as layer 2). \\
\hline 5 & $\begin{array}{l}\text { Below the medium- to coarse-grained sand (layer } 4 \text { ) is a coarse } \\
\text { sandy gravel. It is an open-framework gravel. The matrix sand is } \\
\text { coarse and granular. Silt and clay, if present, are generally } \\
\text { restricted to thin (1-cm), discontinuous beds and gravel clast } \\
\text { coatings. Mud filling pores in gravel is not common. }\end{array}$ \\
\hline $6-9$ & $\begin{array}{l}\text { Hanford formation, fine-grained units--Approximately } 33 \text { to } 49 \mathrm{~m} \\
(110 \text { to } 160 \mathrm{ft}) \text {. }\end{array}$ \\
\hline 6 & $\begin{array}{l}\text { This is primarily a medium- to fine-grained sand. Well-bedded } \\
\text { sands and silty interbeds probably are present. On the scale of } \\
\text { the crib, these interbeds may be fairly continuous. }\end{array}$ \\
\hline 7 & $\begin{array}{l}\text { Similar to layer } 6 \text { but finer grained. Interbedded silt more } \\
\text { abundant. }\end{array}$ \\
\hline 8 & $\begin{array}{l}\text { Gravelly sand lenses occur near the base of this unit and pinch out } \\
\text { under the crib. These lenses probably consist of sands and } \\
\text { interbedded silts with several interbedded gravel layers a few } \\
\text { centimeters thick. These gravels are probably matrix supported. }\end{array}$ \\
\hline 9 & Medium- to fine-grained sand (similar to layers 6 and 7 ). \\
\hline 10 & $\begin{array}{l}\text { Early "Palouse" soil--Approximately } 49 \text { to } 50 \mathrm{~m}(160 \text { to } 162 \mathrm{ft}) \text {. } \\
\text { This soil consists of mainly silts cemented with } \mathrm{CaCO}_{3} . \mathrm{CaCO}_{3} \text { is } \\
\text { disseminated throughout the unit and stringers of } \mathrm{CaCO}_{3} \text { generally } \\
\text { are not well developed. }\end{array}$ \\
\hline $11-12$ & Plio-Pleistocene unit--Approximately 50 to $52 \mathrm{~m}$ (162 to $171 \mathrm{ft}$ ). \\
\hline 11 & $\begin{array}{l}\text { This is primarily a basalt-rich gravelly sand that is generally } \\
\text { matrix rich and matrix supported. Abundant } \mathrm{CaCO}_{3} \text { stringers, } \\
\text { lenses, and massive } \mathrm{CaCO}_{3} \text { are common. The unit is usually very } \\
\text { muddy. }\end{array}$ \\
\hline 12 & $\begin{array}{l}\text { A sand-rich lower part with abundant } \mathrm{CaCO}_{3} \text { stringers and lenses is } \\
\text { present. Massive } \mathrm{CaCO}_{3} \text { may also be present in the area. This unit } \\
\text { consistently has } \mathrm{CaCO}_{3} \text { in it where it is encountered, and is } \\
\text { probably continuous on the scale of the crib. }\end{array}$ \\
\hline
\end{tabular}


WHC-EP-0664

\begin{tabular}{|c|l|}
\hline Layer & \multicolumn{1}{|c|}{ Description } \\
\hline $13-14$ & Ringold Formation--Approximately 52 to $169 \mathrm{~m}(171$ to $555 \mathrm{ft}$ ). \\
\hline 13 & $\begin{array}{l}\text { The upper part of the Ringold Formation is mainly a medium- to } \\
\text { coarse-grained sand. Logs suggest abundant, silty interbeds } \\
\text { (paleosols/overbank deposits) The fine-grained horizons are } \\
\text { probably continuous on the scale of the crib. }\end{array}$ \\
\hline 14 & $\begin{array}{l}\text { The remainder of the Ringold Formation encountered at the crib } \\
\text { consists of gravels and sands. Gravels are well compacted to } \\
\text { cemented and are part of gravel unit E. Cementing is } \\
\text { discontinuous. The gravels are generaily clast to lesser matrix } \\
\text { supported. The matrix commonly consists of fine- to medium-grained } \\
\text { sand. Mud content is generally less than 5\%. }\end{array}$ \\
\hline
\end{tabular}

\subsubsection{Groundwater Quality}

This section describes the groundwater conditions at the $216-\mathrm{U}-17 \mathrm{Crib}$ site. The hydrologic parameters of this area are summarized in the previous sections.

4.3.3.1 200 West Contaminant Plumes. The present extent of contaminant plumes for the 200 West Area has been addressed by Johnson (1993).

This section summarizes the extent of 200 West Area contaminant plumes in the vicinity of the 216-U-17 Crib.

- Chromium--Three areas of chromium contamination appear to exist in the 200 West Area as shown in Figure 18. A11 three of the applicable regulatory standards for this constituent (Washington water quality standard, drinking water standard, and maximum contamination level) are equivalent (50 ppb) and exceed the detection limit ( $10 \mathrm{ppb})$. One area of contamination is apparently located in the southeast corner of the 200 West Area near the 216-U-17 Crib.

- Fluoride--Two minor areas of fluoride contamination potentially exist in the 200 West Area that exceed the drinking water standard and the maximum contamination level standard of $4 \mathrm{ppm}$ (Figure 19). The zones of elevated fluoride also appear to coincide with the arsenic and chromium anomalies. No anomalies occur at the 216-U-17 Crib site. 
Figure 12. 216-U-17 Site Diagrammatic Geology. (See Figure 3 for location of boreholes.)
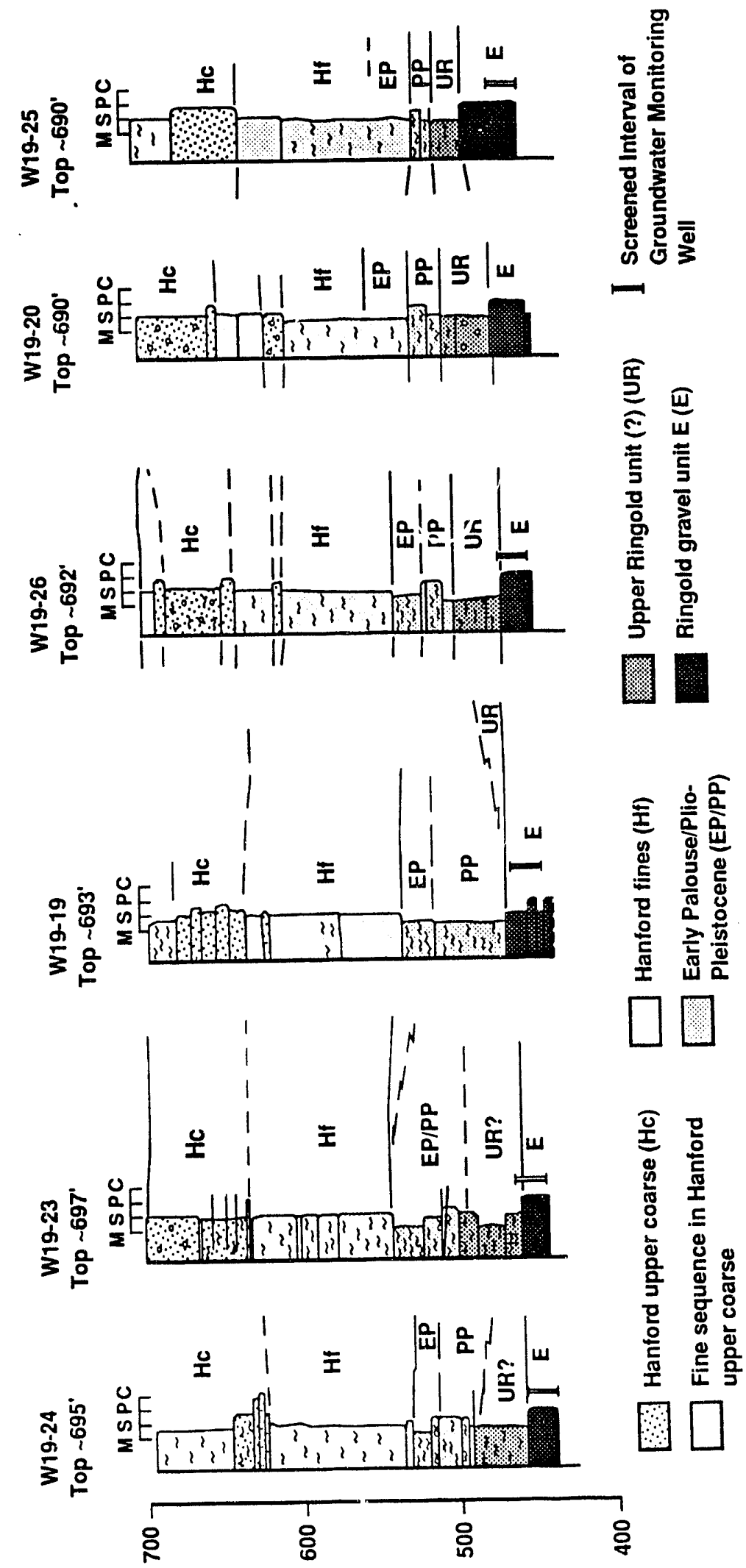
WHC-EP-0664

Figure 14. Location of Cross Sections.

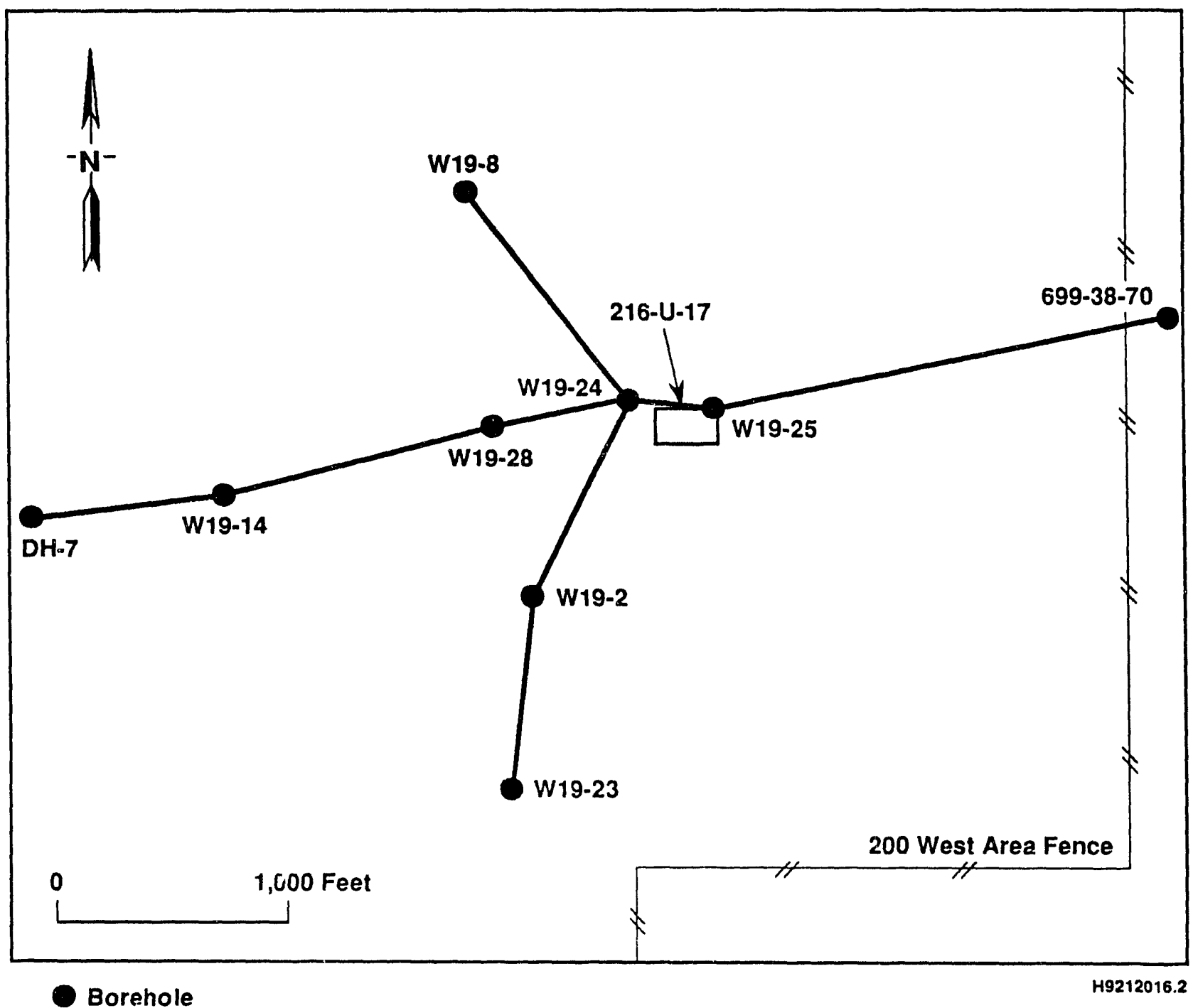


Figure 15. East-West Geologic Cross Section Through the 216-U-17 Crib and Vicinity. (See Figure 14 for location of section.)

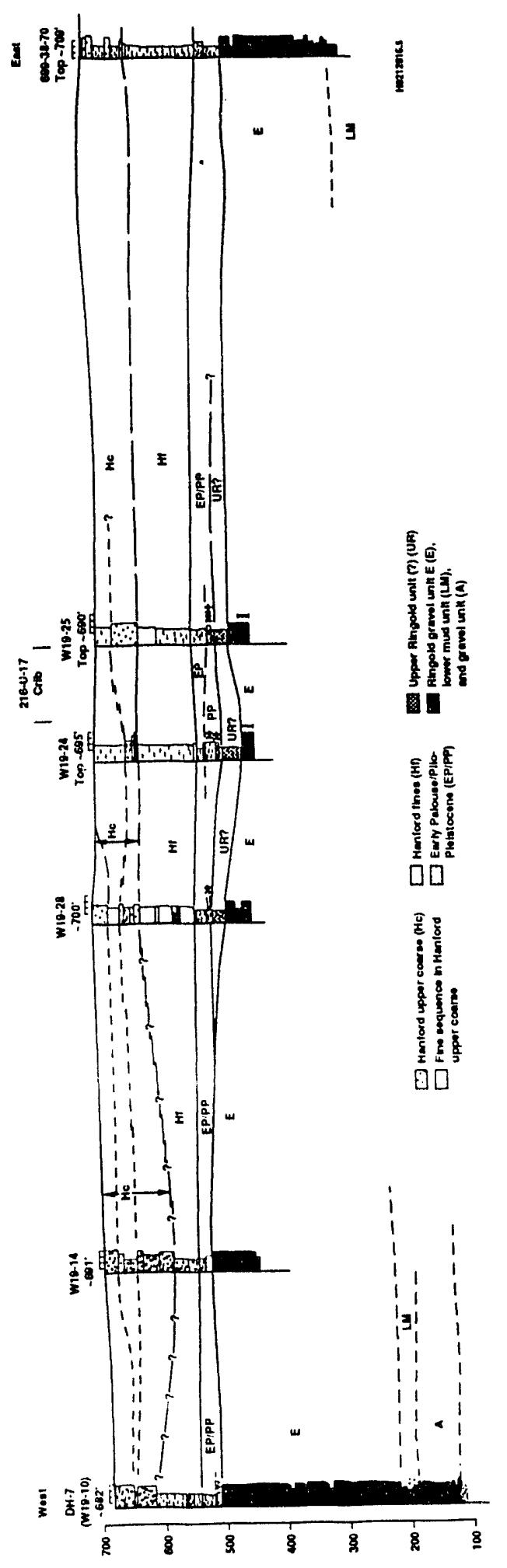


Figure 16. North-South Geologic Cross Section Through the 216-U-17 Crib and Vicinity.

(See Figure 14 for location of section.)

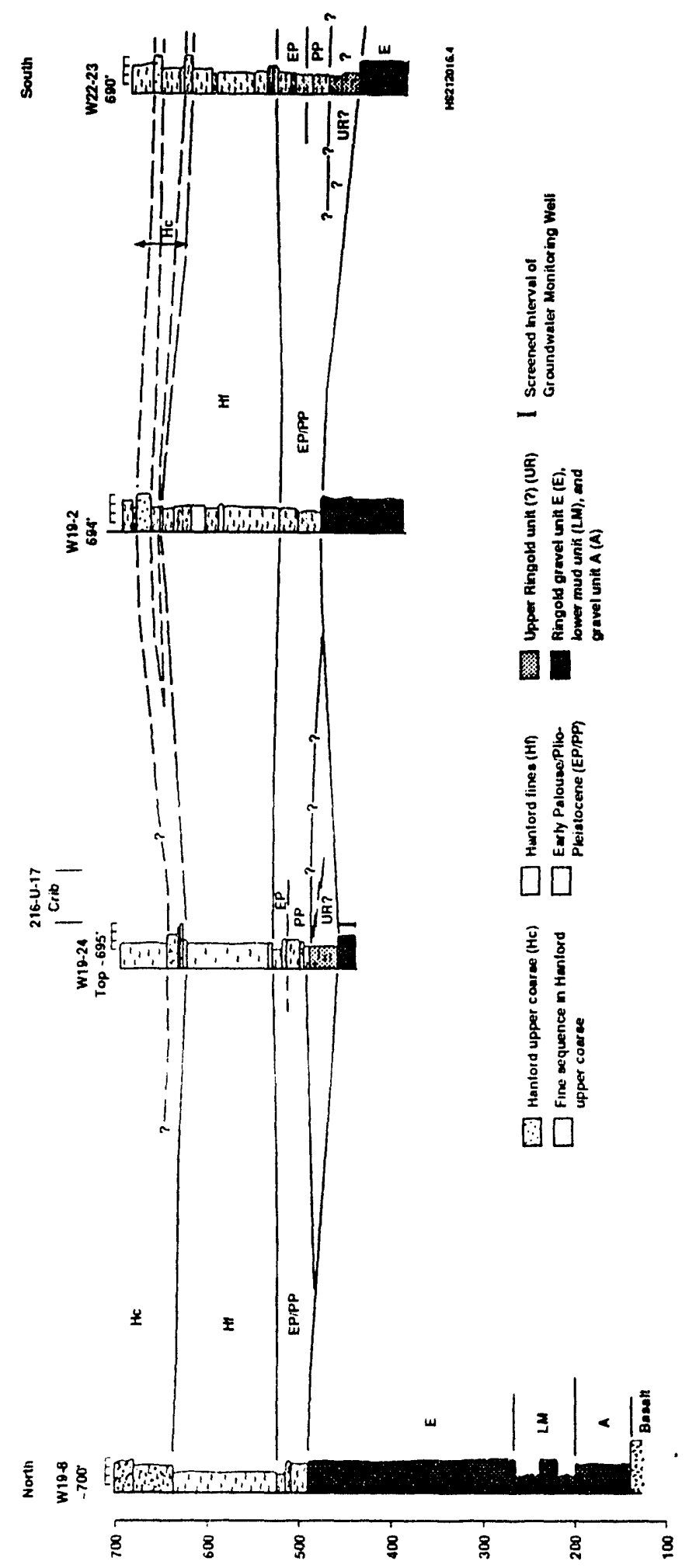


Figure 17. Geohydrologic Model for the 216-U-17 Crib.

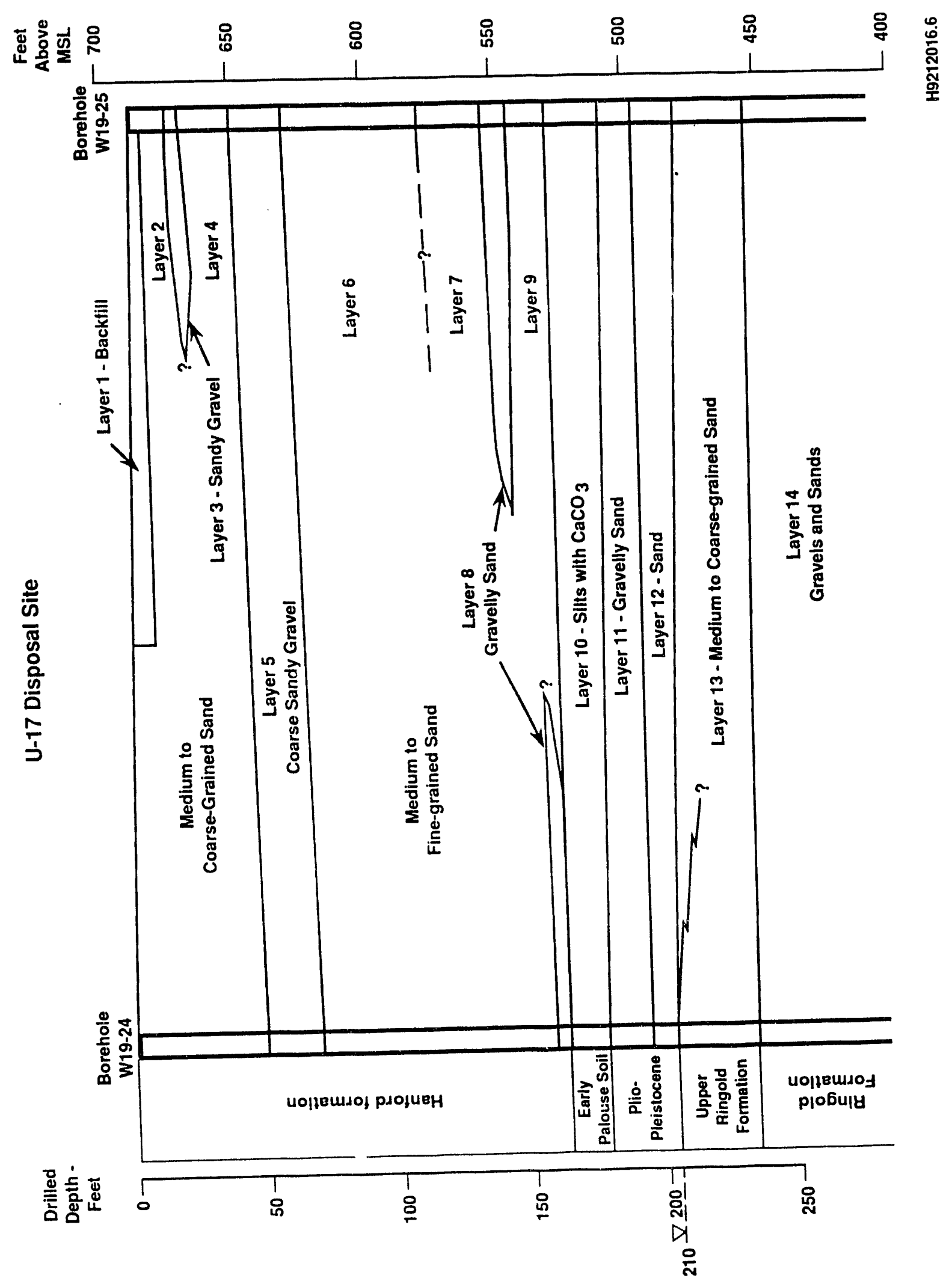


WHC-EP-0664

Figure 18. Chromium Plume Map, 200 West Area.

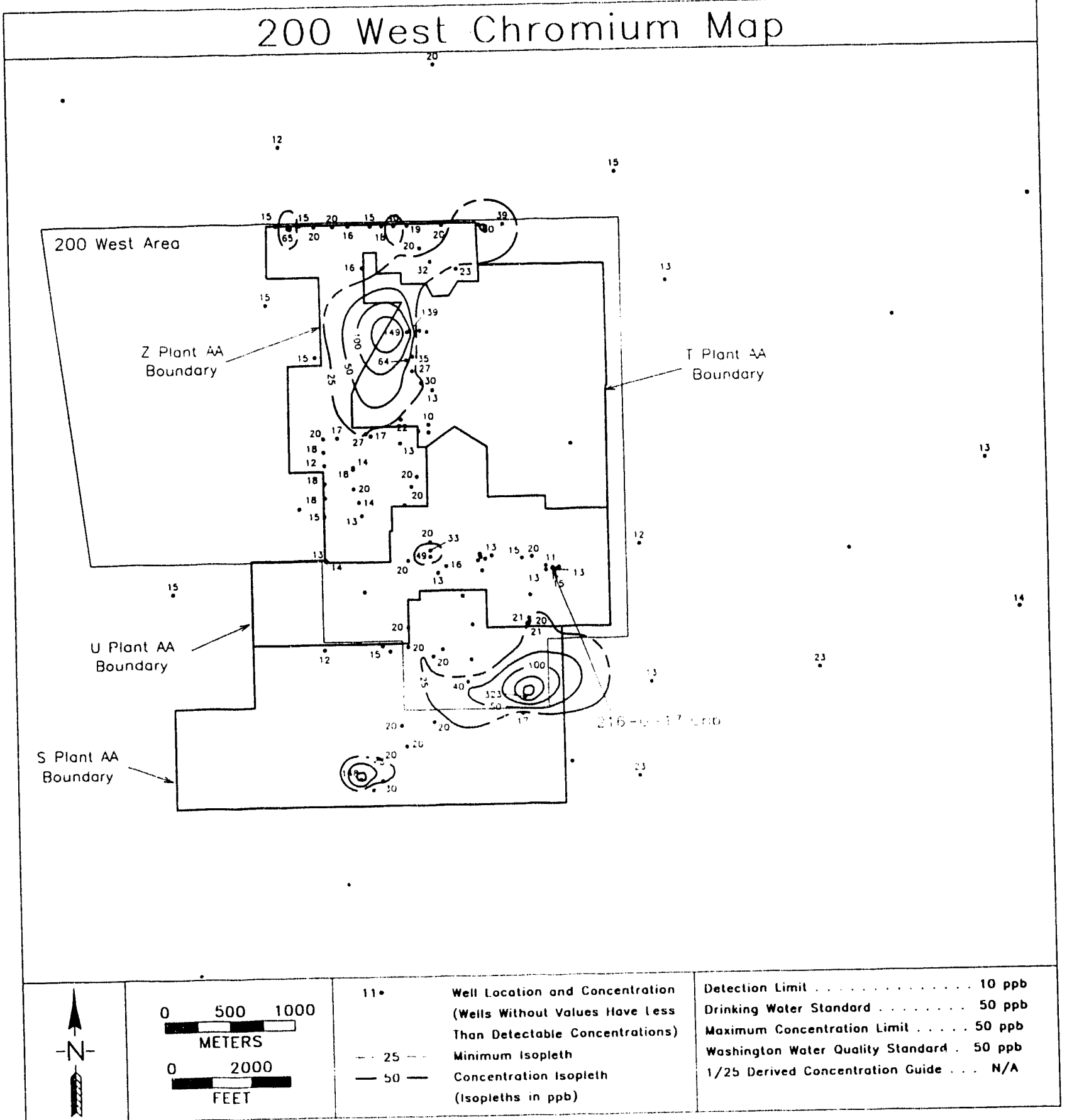


Figure 19. Fluoride Plume Map, 200 West Area.

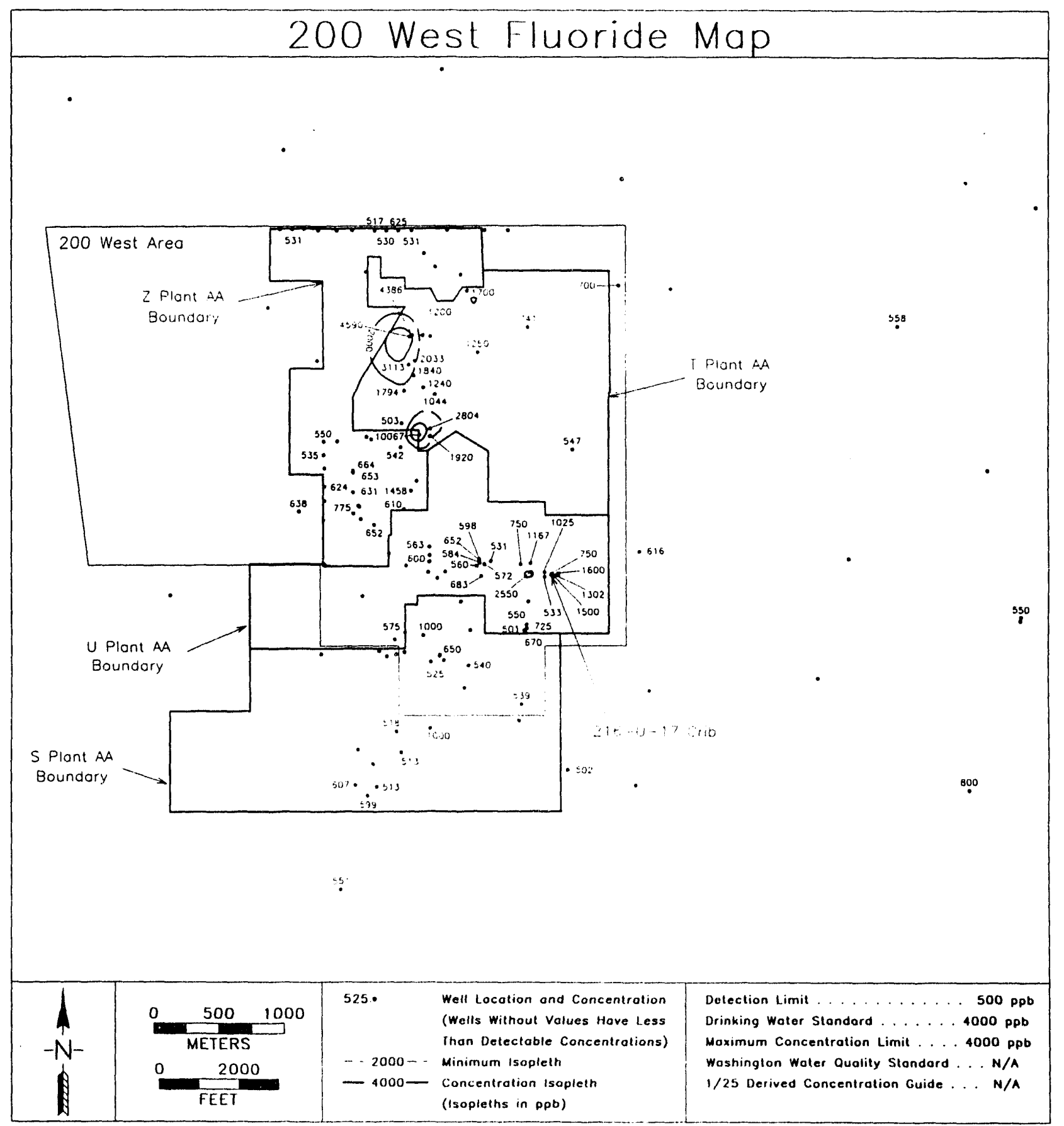


- Carbon tetrachloride--The distribution of this constituent in the 200 West Area is described in detail in DOE-RL (1991) and the contaminant plume map for that study is reproduced in Figure 20. The data are based on averaged data for the period January 1988 to May 1991. The wide areal extent and high concentrations in relation to the 0.3-ppb standard make this occurrence the single most significant impact on groundwater quality beneath the Hanford Site. The 216-U-17 Crib site appears to lie in the southeast portion of the area covered by this plume.

- Nitrate--The nitrate plume in the 200 West Area (Figure 21) shows a wide distribution reflecting the mobility and multiple sources of this ubiquitous contaminant. The primary area of contamination is centered beneath the central portion of the 200 West Area and extends well beyond the 200 West Area fenceline to the northeast/east. High concentrations of nitrate occur in the vicinity of the $216-U-17$ Crib.

- Gross alpha and gross beta--The primary occurrences of radioactive contaminants beneath the 200 West Area are in the southern and northeastern portions of the area. This distribution is well illustrated with the gross alpha and gross beta plume maps (Figures 22 and 23). Most of the gross alpha is associated with uranium breakthrough from the 216-U-1/2 Cribs and possible leaks from transfer lines from $\mathrm{U} / \mathrm{UO}_{3}$ Flant that occurred during and before 1985. These plumes extend under the 216-U-17 Crib.

- ${ }^{129}$ I--Two distinct plumes beneath the 200 West Area are illustrated in Figure 24. The plumes coincide with the general radionuclide distribution discussed previously but also extend well to the southeast of the 200 West Area and share a similar distribution pattern with tritium. The 216-U-17 Crib overlies the northern part of the ${ }^{129} \mathrm{I}$ plume.

- ${ }^{99} \mathrm{Tc}$--The distribution of ${ }^{99} \mathrm{Tc}$ in the 200 West Area (Figure 25) is most similar to the gross alpha and uranium plumes and is attributed to a common source for uranium and ${ }^{99} \mathrm{Tc}$, the past-practice disposal of process condensates from the $\mathrm{UO}_{3} \mathrm{Pl}$ ant to the $216-U-1 / 2,216-U-8$, and $216-U-12$ Cribs. The 216-U-17 Crib overlies this plume.

- Tritium--The distribution of this constituent beneath the 200 West Area is shown in Figure 26. The general distribution pattern is similar to ${ }^{129} \mathrm{I}$, probably reflecting a common source caused by past disposal of process condensate waste from the nuclear fuel dissolution and extraction activities at the Reduction Oxidation (REDOX) Plant located near the southern end of the 200 West Area. The 216-U-17 Crib lies north of the southern plume.

- Uranium--Uranium contamination appears in two areas beneath the 200 West Area (Figure 27). The area in the southwest corner coincides with the ${ }^{99}$ Tc plume. There appears to be a slight difference between the uranium and technetium distribution pattern, however, possibly reflecting a difference in mobility and/or source (Johnson 1993). The slow rate of movement in this area (ca. 0.3 to $0.6 \mathrm{~m} / \mathrm{day}$ [ 1 to $2 \mathrm{ft} / \mathrm{day}])$, accounts for the limited size of the 
Figure 20. Carbon Tetrachloride Plume Map, 200 West Area.

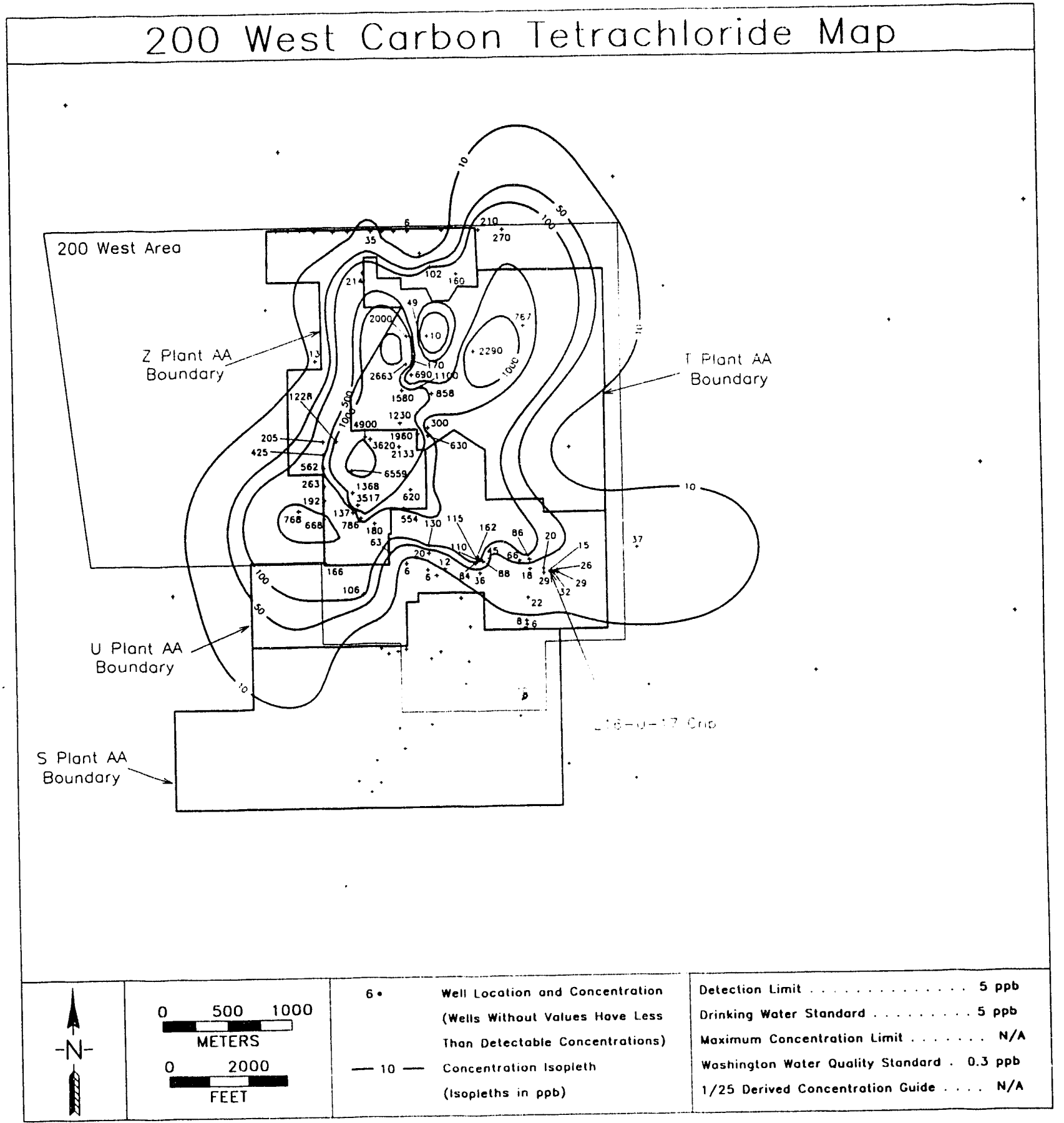


Figure 21. Nitrate Plume Map, 200 West Area.

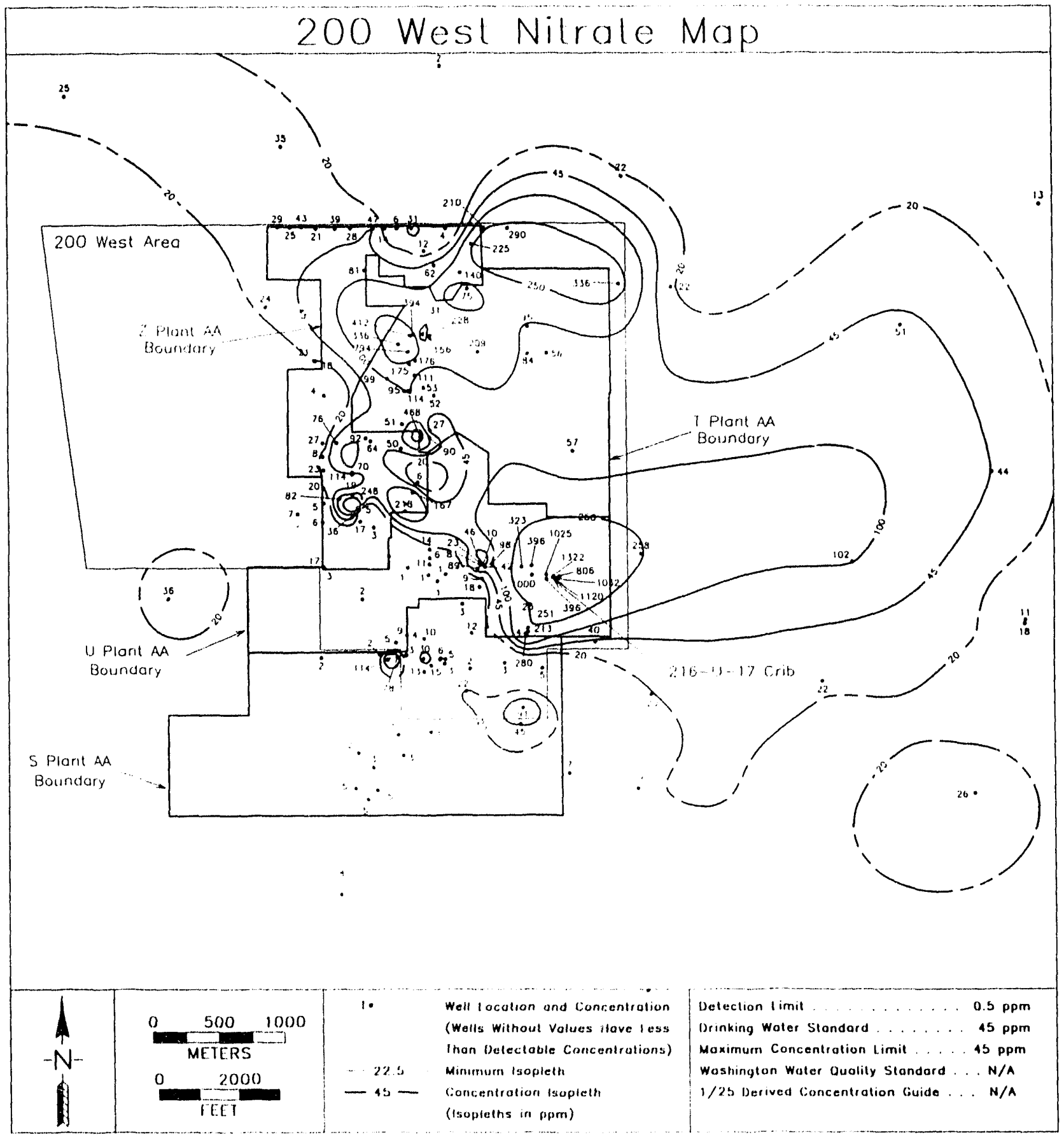


Figure 22. Gross Alpha Plume Map, 200 West Area.

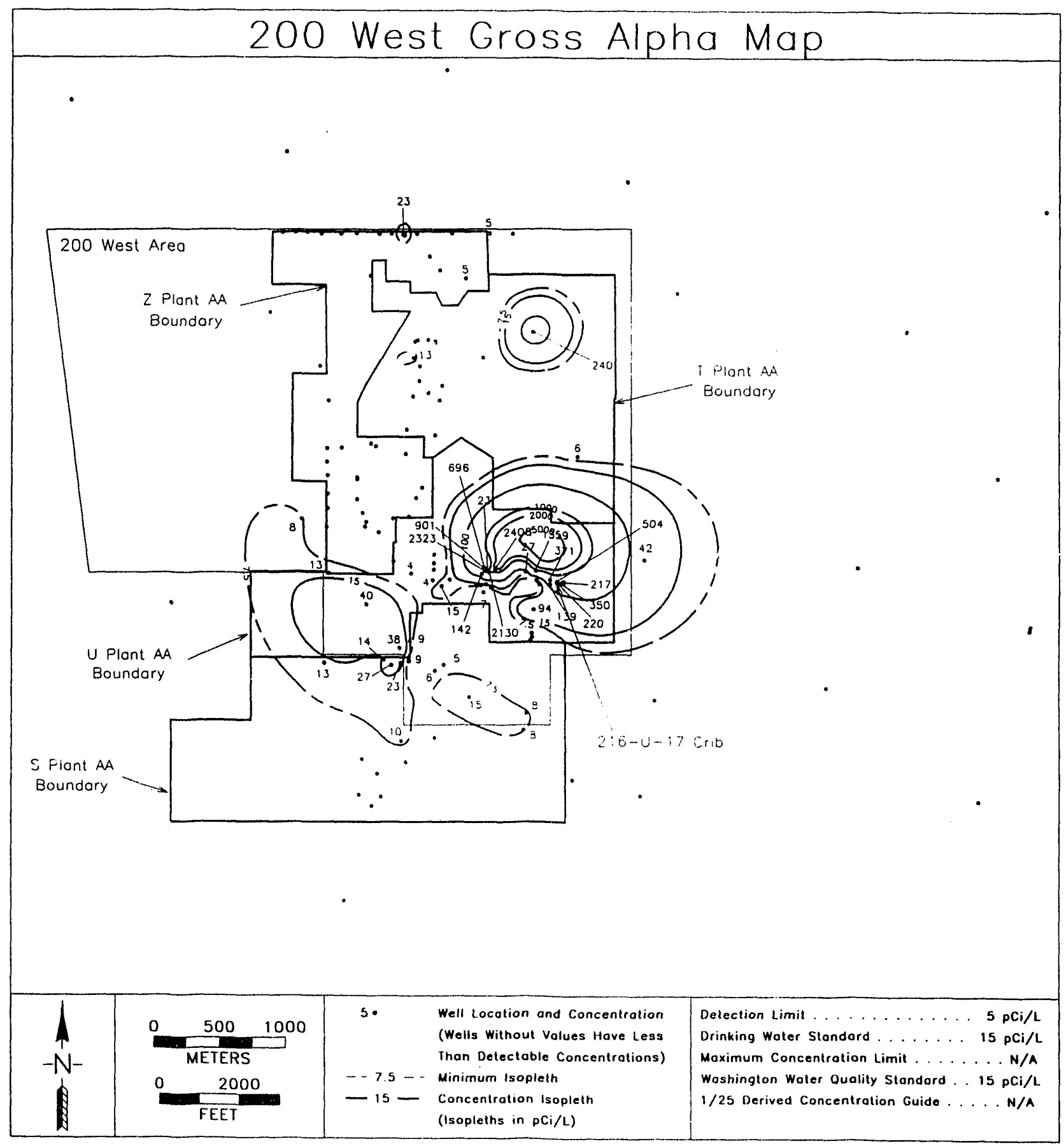


WHC-EP-0664

Figure 23. Gross Beta Plume Map, 200 West Area.

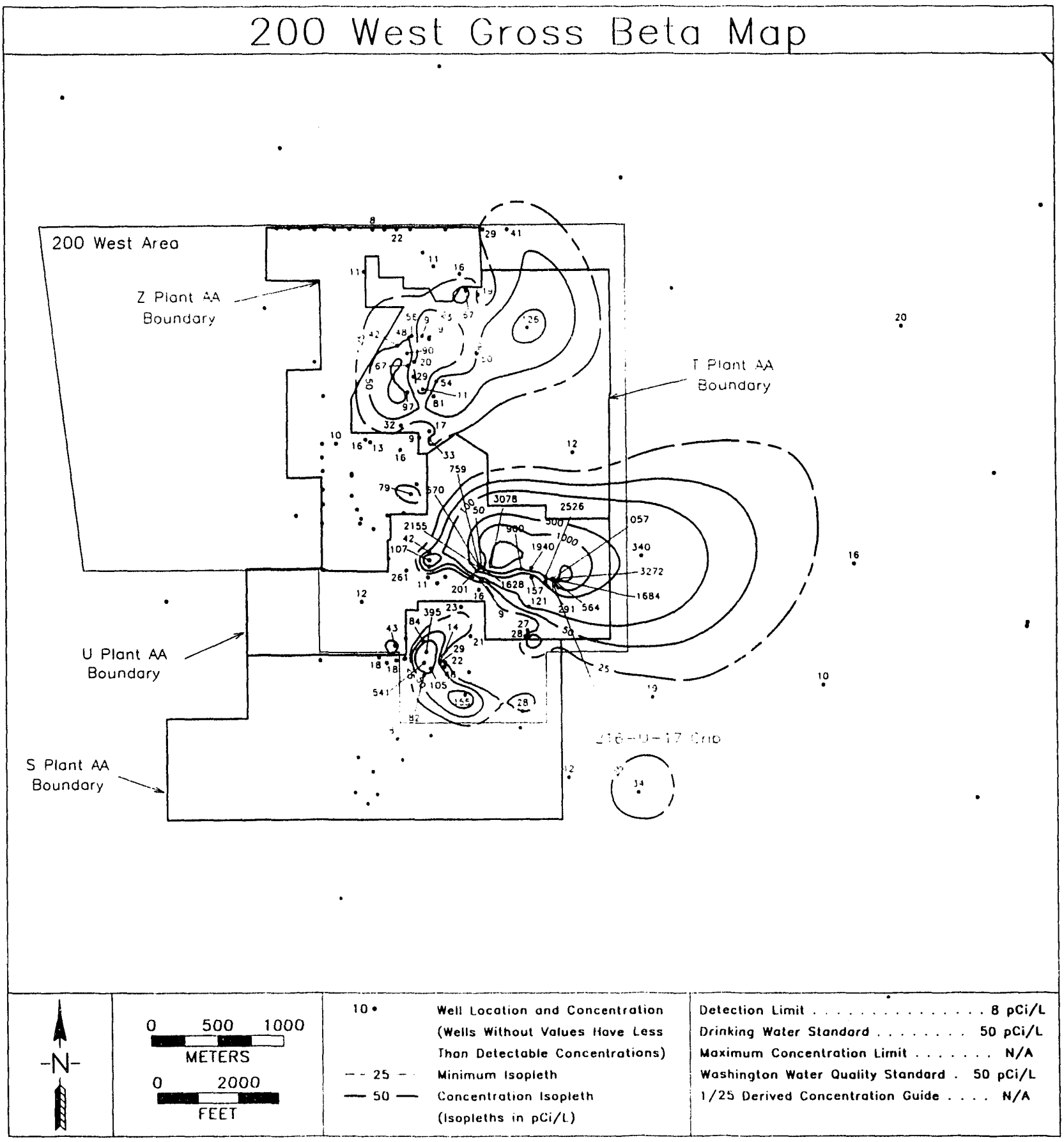


Figure 24. Iodine-129 Plume Map, 200 West Area.

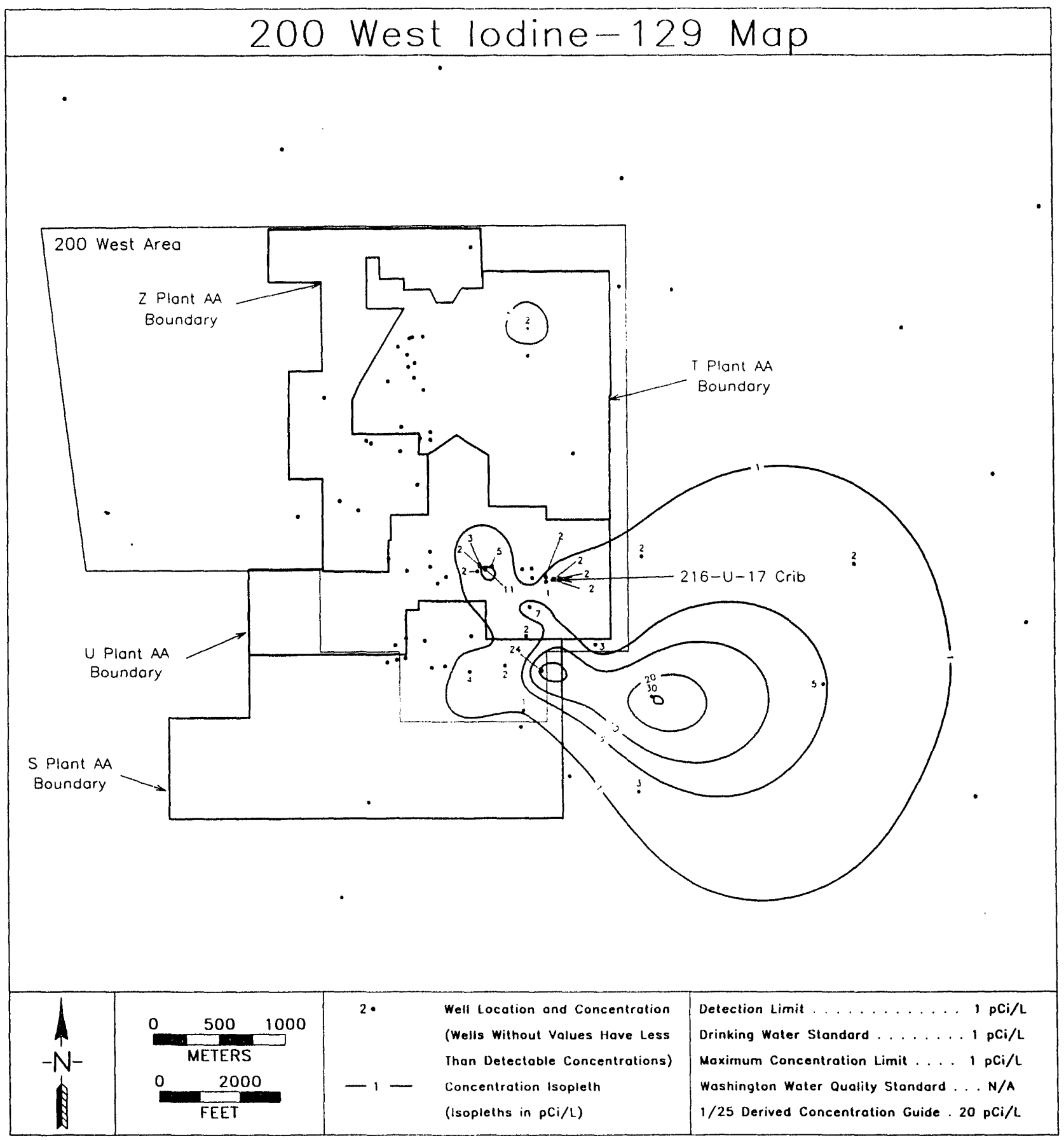


WHC-EP-0664

Figure 25. Technetium-99 Plume Map, 200 West Area.

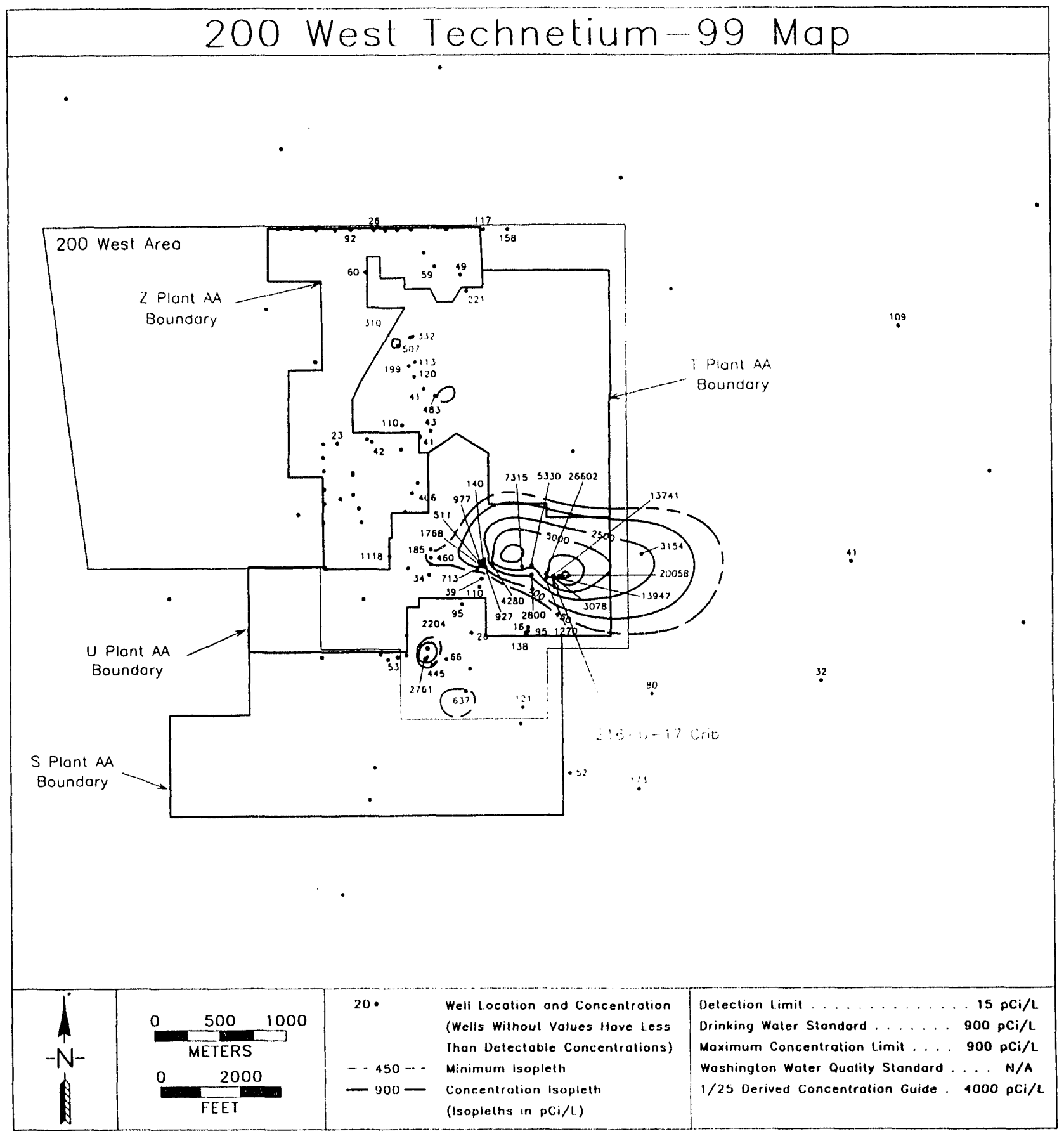


Figure 26. Tritium Plume Map, 200 West Area.

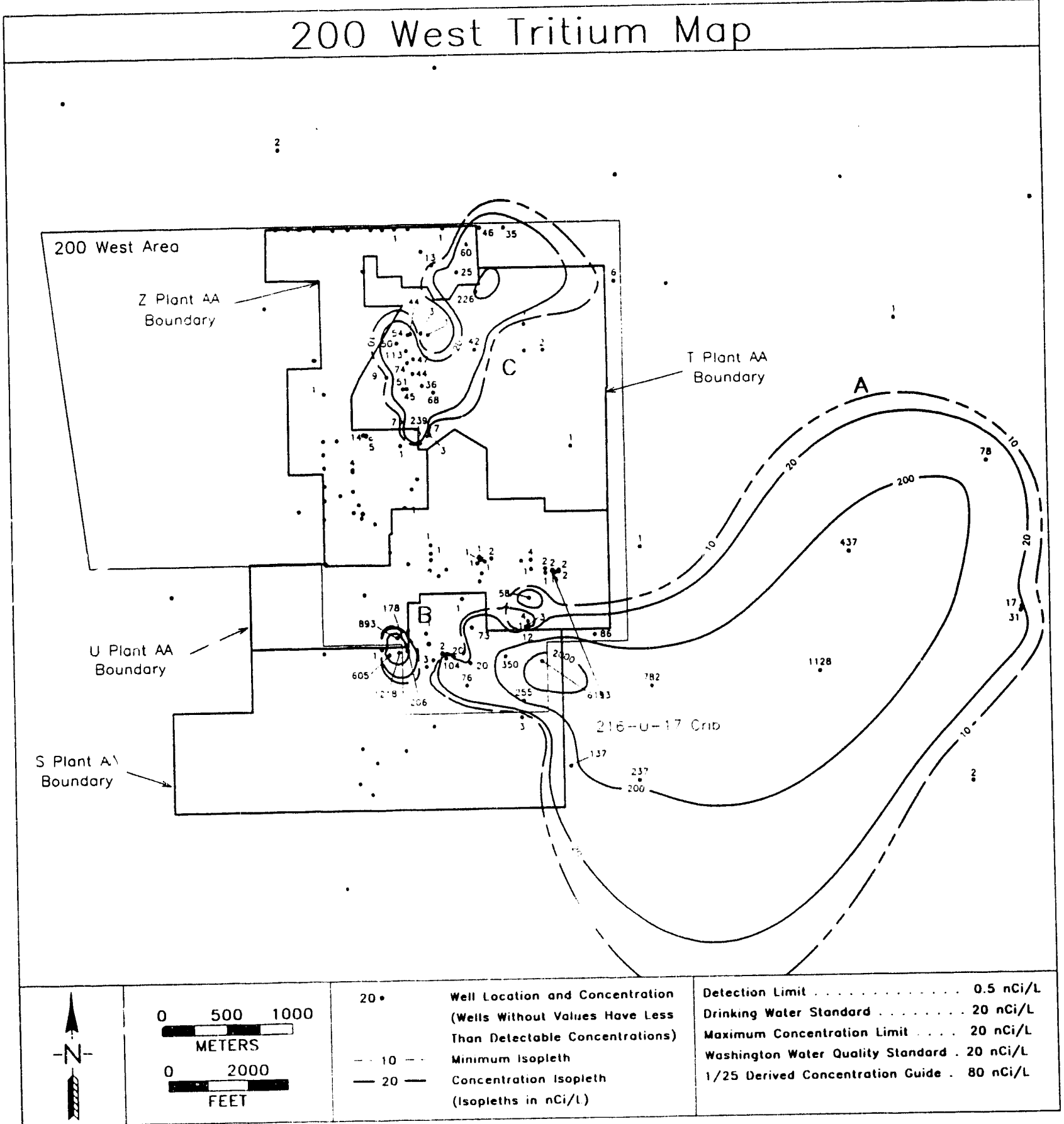


Figure 27. Uranium Plume Map, 200 West Area.

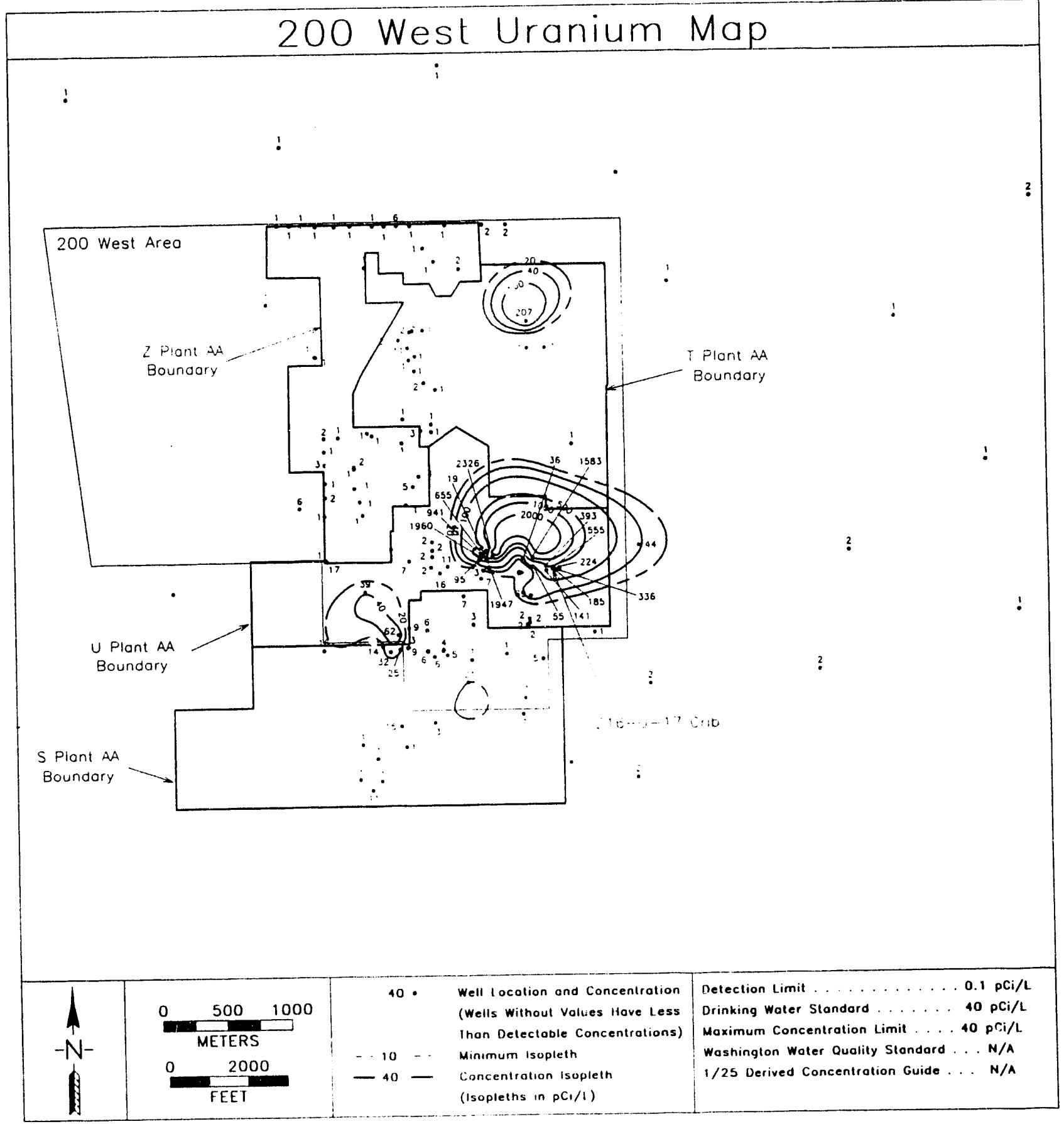


plume (i.e., the primary source of uranium was the crib breakthrough event in 1985 while the tritium and iodine sources date back to the start of REDOX Plant operations in the 1950's). The 216-U-17 Crib lies over the east-central plume.

\subsubsection{6-U-17 Crib Site Groundwater Quality}

The major groundwater contaminant sources in the 200 West Area originated from the $Z$ Plant/Plutonium Finishing Plant complex and associated liquid waste disposal sites. The second largest source of recent groundwater contamination arises from the $\mathrm{UO}_{3} \mathrm{Pl}$ ant operations. Past disposal activities associated with REDOX nuclear fuel reprocessing activities included discharge of process condensates containing large amounts of tritium and ${ }^{129} \mathrm{I}$, which account for the widespread plumes of these highly mobile radionuclides in the southeast 200 West Area near the 216-U-17 Crib.

A detailed inventory of 200 West Area waste sites, geohydrology, groundwater monitoring facilities, and contaminant geochemistry is contained in the 200 West Area Groundwater Aggregate Area Management Study Report (DOE-RL 1992). The following summary of groundwater quality and hydrologic conditions in the 200 West Area reviews the impacts of these past-practice sources on groundwater conditions at the 216-U-17 Crib.

- U Plant area--The primary source of the ${ }^{99} \mathrm{TC}$, uranium, gross beta, gross alpha, and nitrate plumes previously discussed can be traced to past-practice disposal of process condensate from the $\mathrm{UO}_{3} \mathrm{Plant}$. From 1950 to the present, these wastes, with highly variable amounts of treatment, were discharged to the series of cribs shown in Figure 1. In addition to the cribs, the transfer lines running from the U Plant complex to the cribs may have leaked because of the corrosive nature of the liquid waste (e.g., dilute nitric acid) before disposal in the 216-U-17 Crib.

An effluent discharge history for the most important cribs is shown in Figure 28. As illustrated, the largest waste volume was received by the 216-U-8 Crib. However, the greatest quantity of radioactive waste was added to the $216-\mathrm{U}-1 / 2$ Cribs. In 1985 large volumes of water were discharged to the adjacent 216-U-16 Crib, resulting in mobilization of uranium and ${ }^{99} \mathrm{Tc}$ stored in the soil column beneath the $216-U-1 / 2$ Cribs. This resulted in uranium concentrations in groundwater of nearly $80,000 \mathrm{pCi} / \mathrm{L}$ in one well nearest the source of contamination. A partially successful pump-and-treat campaign was conducted in 1986 to mitigate the inadvertent groundwater contamination event.

In addition to the above source, which is now migrating east, the other cribs, 216-U-8 and 216-U-12, received similar corrosive wastewater but with lower radionuclide concentrations. The waste line running south from the $U$ Plant area to these two cribs appears to have leaked. This is shown in groundwater monitoring wells located upgradient and downgradient from the line, indicating much higher concentrations of uranium and ${ }^{99} \mathrm{TC}$ in the downgradient well. Thus groundwater containing elevated uranium, nitrate, and ${ }^{99} \mathrm{Tc}$ from these past-practice sources is migrating from west to east across 
Figure 28. Process Condensate Discharge History of the $\mathrm{UO}_{3} \mathrm{Pl}$ ant Cribs.

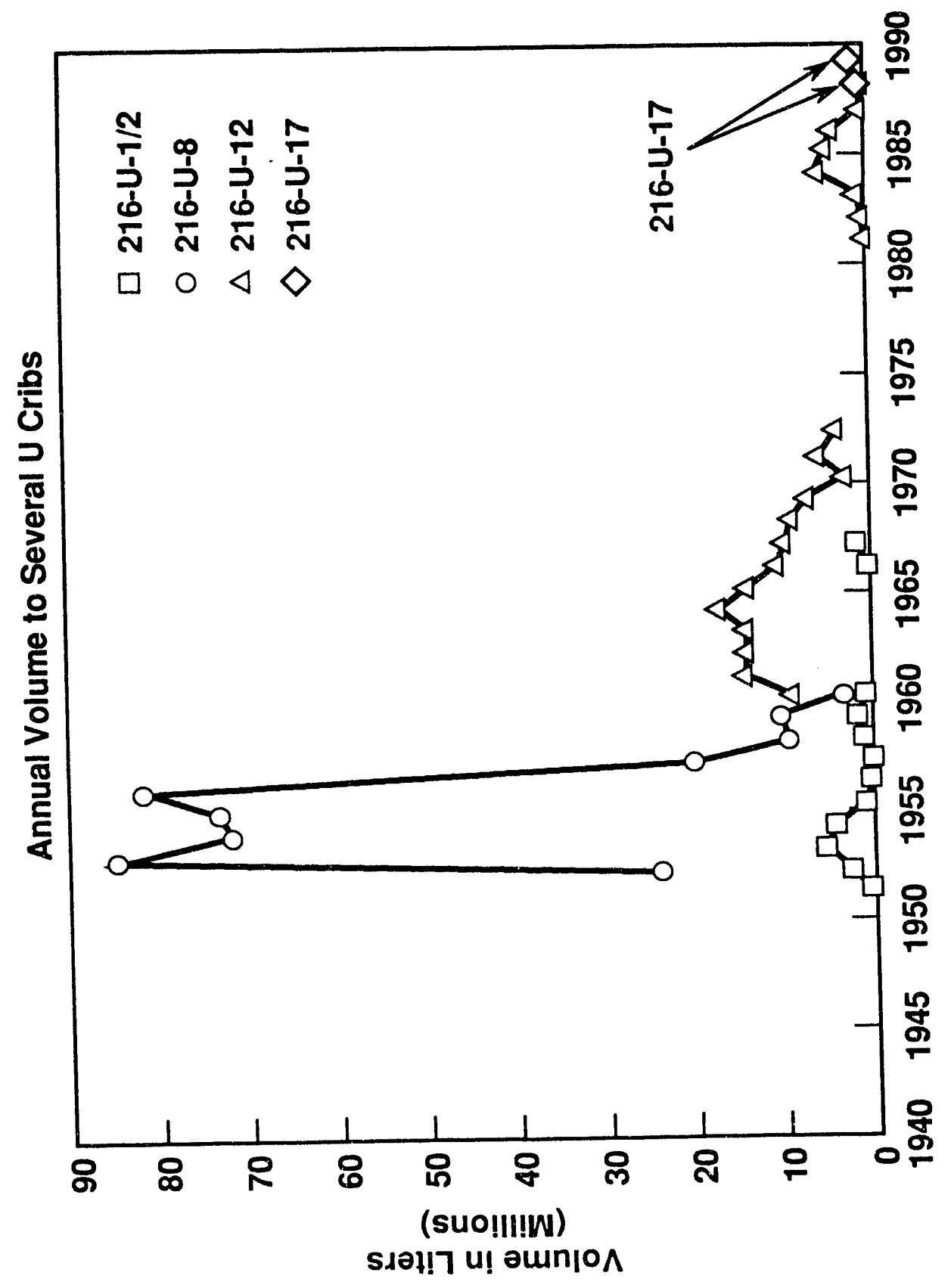


the area south of $U$ Plant (221-U in Figure 1) and beneath the 216-U-17 Crib.

Graphic enhancements of the plume maps (Johnson 1993), including superimposed water level contours and waste site locations, are shown in Figures 29 and 30 . These plots show that the general direction of groundwater flow, based on the water table contours, coincides reasonably well with the plume locations. There appears to be a difference in the uranium and ${ }^{99} \mathrm{Tc}$ distribution patterns, which may reflect different source strengths and/or migration rates for these two radionuclides. The rate of groundwater movement near the axis of the two plumes has been estimated at approximately $0.3 \mathrm{~m} /$ day ( $1 \mathrm{ft} /$ day) (Connelly et al. 1992a).

- 216-U-17 Crib--The primary constituents of concern detected in groundwater beneath this crib during the Liquid Effluent Study Final Project Report (WHC 1990a) were those discussed previously as well as above-background occurrences of copper and zinc.

Concentration history plots for gross beta and ${ }^{99} \mathrm{TC}$ (Figure 31) illustrate the influence of the migrating contaminant plume from upgradient sources. Figure 31 shows that the uranium-technetium plume began arriving at the 216-U-17 Crib even before the crib was placed into use for the first time and that the upgradient concentrations appear to be somewhat greater than the downgradient concentrations. This is illustrated clearly with a cumulative distribution plot for the two wells as shown in Figure 32 . The cumulative distributions are based on all uranium and ${ }^{99} \mathrm{Tc}$ data through the first quarter of 1992 . The distribution curves for the upgradient well (2-W19-24) are clearly displaced to the right from the downgradient well, showing higher concentrations of about a factor of 2.5 for ${ }^{99} \mathrm{Tc}$ and a factor of 1.6 for uranium. The difference between the distribution curves for the two radionuclides probably reflects different sources and/or arrival times.

\subsection{CONCEPTUAL MODEL ELEMENTS}

Using the site-specific stratigraphy for the 216-U-17 Crib, the past discharge history for the crib and planned future discharges to the crib, the following hypothesis or conceptual model is proposed and tested in Section 5.0. The conceptual model consists of two essential considerations or possibilities: the movement of moisture through the vadose zone and the movement of constituents of interest with the moisture.

\subsubsection{Moisture Movement}

Effluent discharged to the 216-U-17 Crib results in moisture moving through the 14-1ayer sediment system, spreading laterally along each layer interface, and breaking through to successively lower sedimentary layers. In one case, the wetting front does not reach the water table, and in the other, the wetting front breaks through to the water table. 
Figure 29. Water Table Map Showing Concentrations of Uranium.

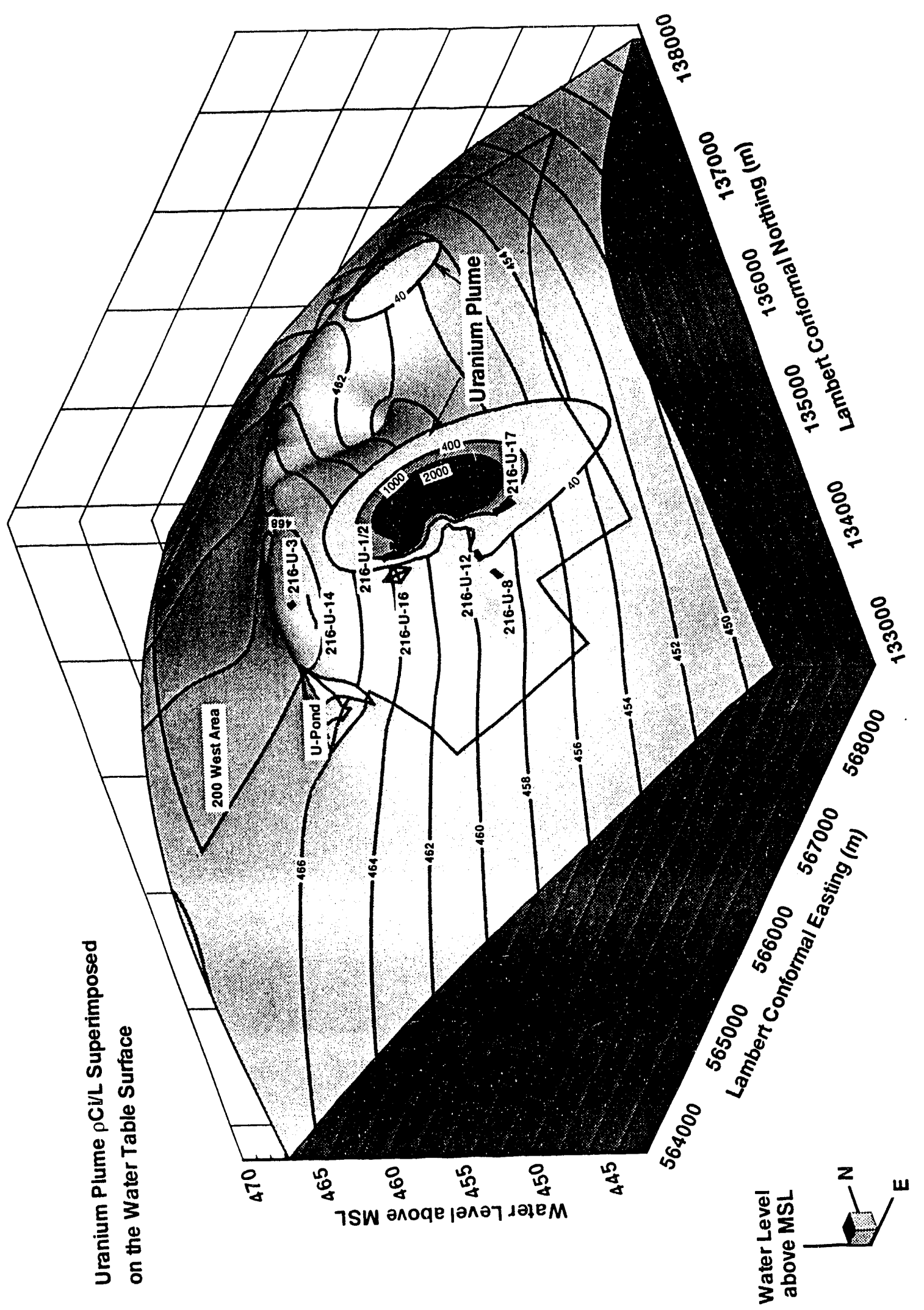


WHC-EP-0664

Figure 30. Water Table Map Showing

Concentrations of Technetium-99.

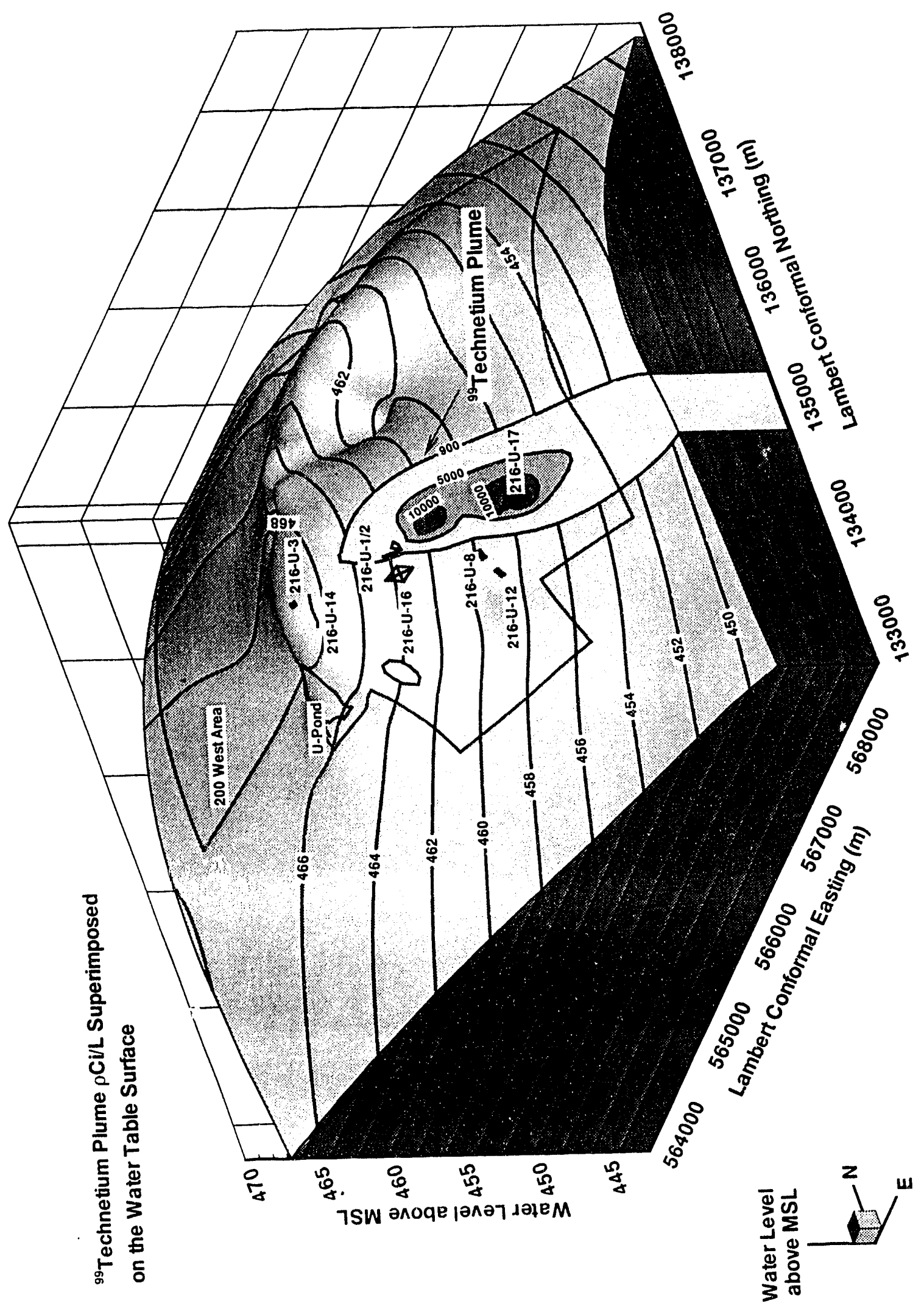


Figure 31. Impact of Adjacent Facilities on Groundwater at the 216-U-17 Crib.
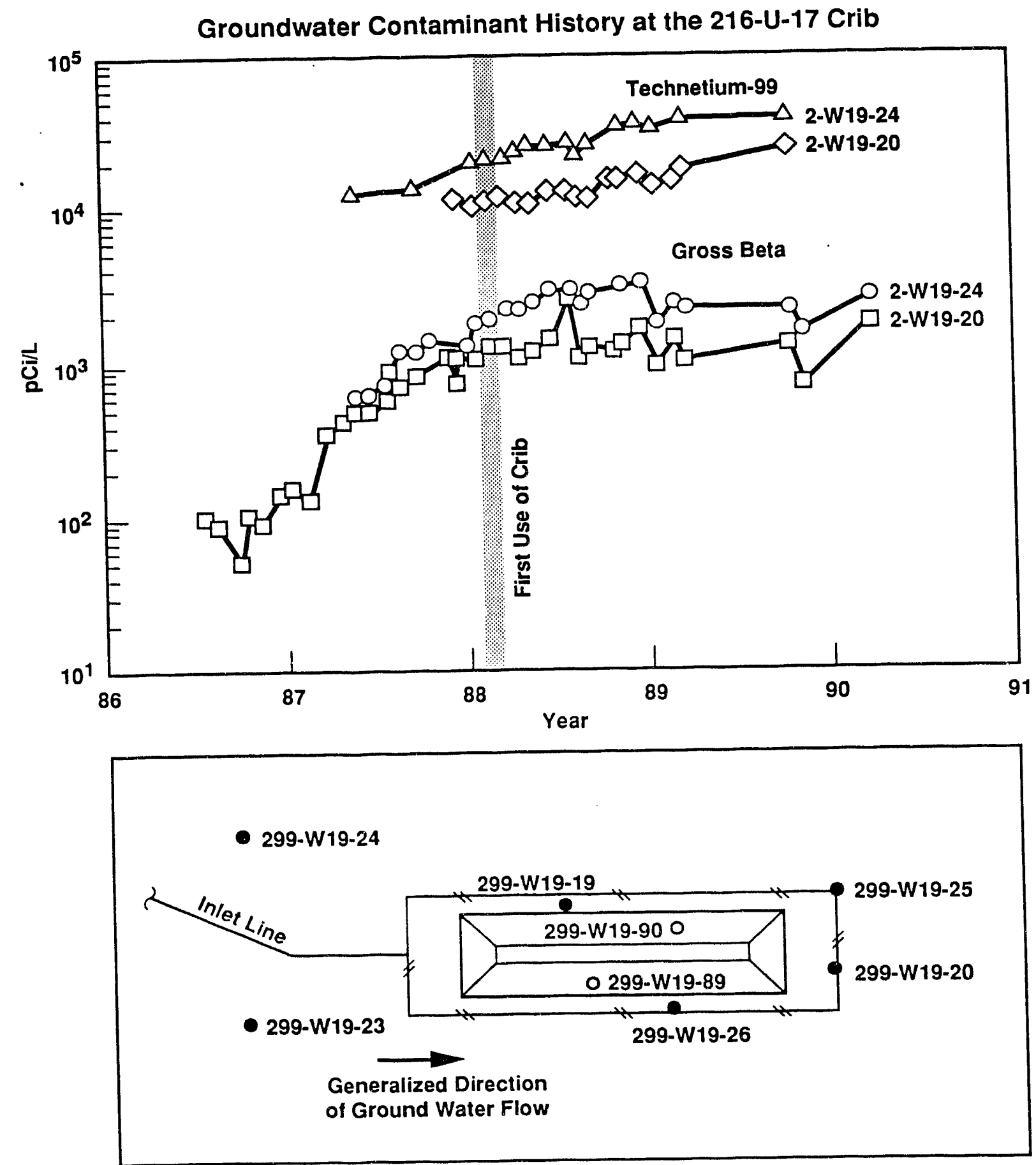

H9212017.3 
Figure 32. Kolmogorov-Smirnov Two-Sample Test of Contaminants in Upgradient and Downgradient Wells at 216-U-17 Crib.
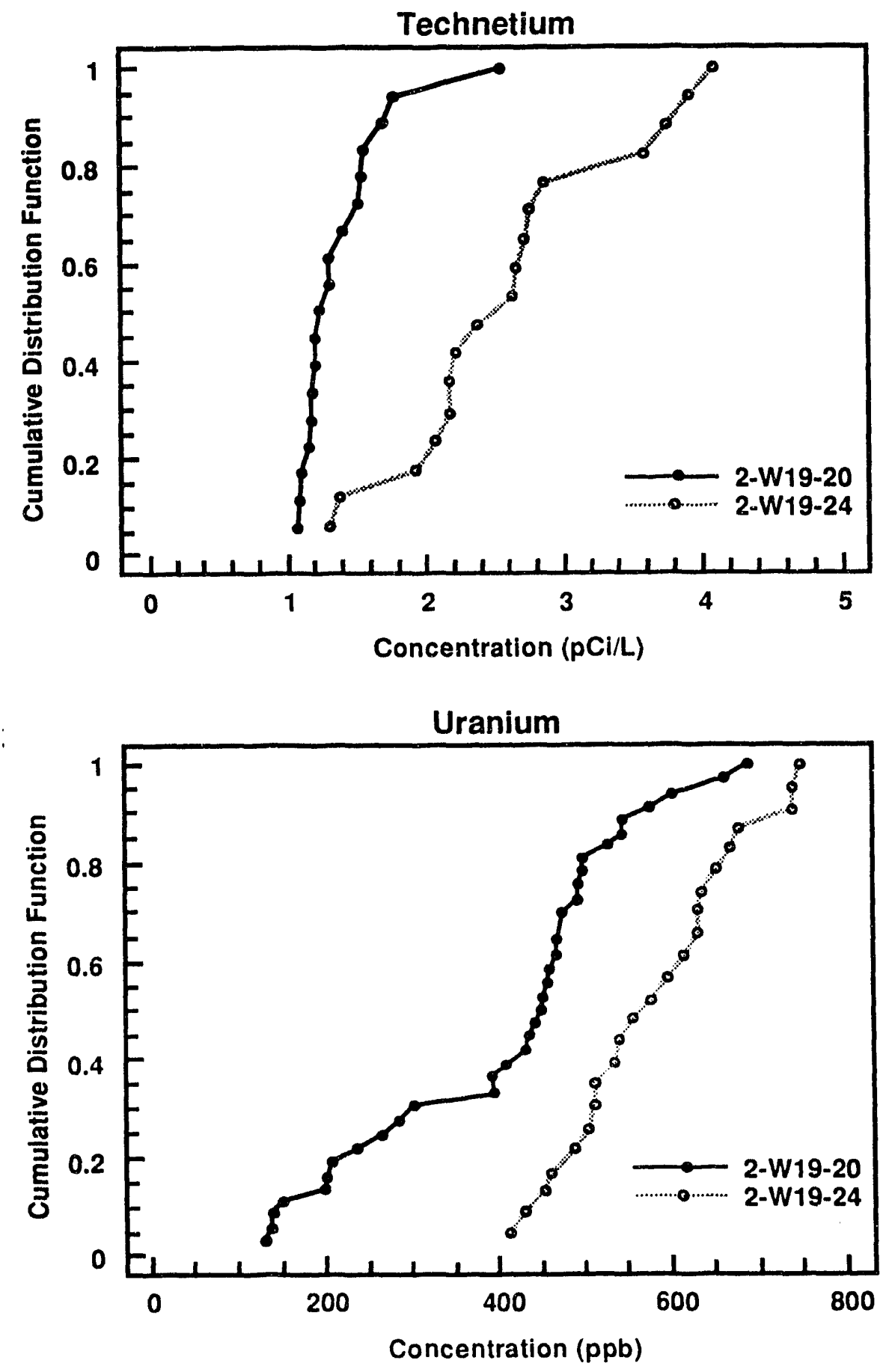


\subsubsection{Movement of Constituents of Interest}

The constituents of interest vary in mobility: (a) ${ }^{99} \mathrm{Tc}$ and nitrate are highly mobile and move with the moisture front, and (b) uranium moves somewhat slower because of sorption or interaction with vadose zone solids. If the moisture front reaches the water table, there are two possibilities: only the moisture and mobile constituents of interest reach the water table, or both retarded and mobile constituents of interest reach groundwater.

A two-dimensional model is used to examine rate of moisture and contaminant migration through the vadose zone to groundwater and to assess impact to the groundwater (see Section 5.0). Because of the relatively low volume of wastewater being discharged to a new crib (one that has not been previously wetted), localized contaminant migration and distribution patterns in the vadose zone are the primary focus of the assessment. As shown in previous sections, the groundwater in the area of the $216-U-17 \mathrm{Crib}$ has already been contaminated by events before the first effluent was discharged to the 216-U-17 Crib. 
WHC-EP-0664

This page intentionally left blank. 


\subsection{IMPACT ASSESSMENT}

This section describes the results of numerical modeling of the vadose zone at the 216-U-17 Crib that were used to assess the impact of discharge of effluent to the crib on the groundwater system. The model parameters and simulations are summarized in Table 7 , which provides a guide to this section. The crib model incorporates the site-specific stratigraphy (see figure 17) and representative hydraul :c properties (Table 8 ) for the vadose zone and unconfined aquifer. Boundary conditions representing both discharges to the 216-U-17 Crib and assumptions regarding recharge because of infiltration of precipitation at the crib site drive various flow and transport simulation cases.

\subsection{FLOW AND TRANSPORT MODEL}

The 216-U-17 Crib is an excavated trench with sloping walls (slope = $2 / 3$ ) ; the floor of the crib is about $3 \mathrm{~m}$ in width and about $46 \mathrm{~m}$ in length, and the depth to the floor from ground surface is about $3 \mathrm{~m}$ (see Section 2.0). The estimated volume of gravel backfjll (including the 6 -in. layer of crushed gravel) in the trench is about $600 \mathrm{~m}^{3}$, and the pore space is approximately $200 \mathrm{~m}^{3}$ (assuming a porosity of $1 / 3$ [Freeze and Cherry 1979]).

The crib capacity is over $56,781 \mathrm{~L}\left(50 \mathrm{~m}^{3}\right) /$ day (see Section 3.0). During the first year and a half of operation of the 216-U-17 Crib, the total discharge was equal in volume to about ten times the pore volume of the gravel backfill. However, the daily average discharge volume over that same period of time was only about one-fiftieth the pore volume of the gravel backfill and less than one-tenth the crib capacity (i.e., less than $4 \mathrm{~m}^{3} / \mathrm{day}$ ). The discharge to the crib is relatively low compared to the capacity of the crib; it is assumed that most of the flux of fluid from the crib to the host soil column is through the floor of the crib and that the effective area through which flux enters the soil column is relatively small compared to the total surface area. Because the perforated pipe through which the effluent waste stream enters the backfill is pitched downward from the point of entry at the west end, it was assumed for previous modeling (Appendix $D$ of the Liquid Effluent Study Final Project Report [WHC 1990a]) that the liquid would collect and enter the soil column through the floor at the east end of the crib. But because the discharge rate is low and the slope of the perforated pipe is small (slope $=0.2 \%$ downward from west to east), it is assumed here that the conservatively small area of influx to the soil is at the west end of the crib. However, because of the extreme contrast in hydraulic properties between the host sand (Hanford formation) and the gravel backfill, it is conceivable that the effluent could migrate along the trench preferentially, until the soil column is wetted.

\subsubsection{Spatial Domain of Crib Model}

The spatial domain for the numerical model extends downward from the approximate mean elevation of the perforated pipe through the backfill (see Figure 3 ) and the suprabasalt sedimentary layers (see Figure 17). The model 
WHC-EP-0664

This page intentionally left blank. 
Table 7. Summary of Numerical Simulation Cases, Soil Column Tr:

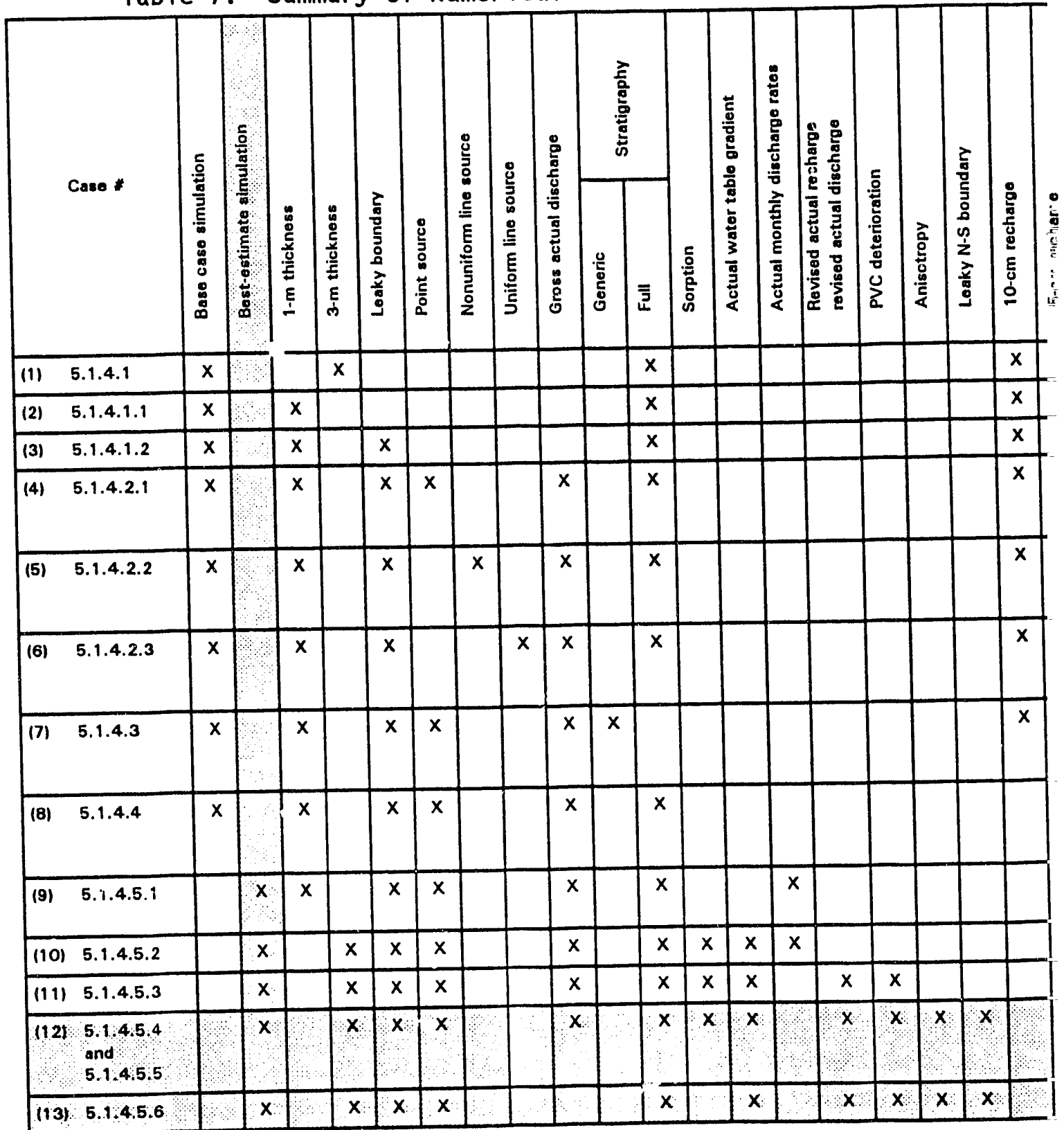

Approximate conversion to activity units (for total uranium) is $0.7 \mathrm{FCi} / \mu$ g.

bo.75 × 15,200 mg/L; see note $d$ for nitrate source.

Based on ratio of prodicted maximum uranium concentration in soil moisturo $\mathrm{K}_{\mathrm{d}}=\mathrm{O}$ ) and maximum uranium

$0.6 \%$ of highest nitrat

ND $=$ not determined. 
r.port Rates, and Maximum Soiute Concentrations in Soil Moisture.

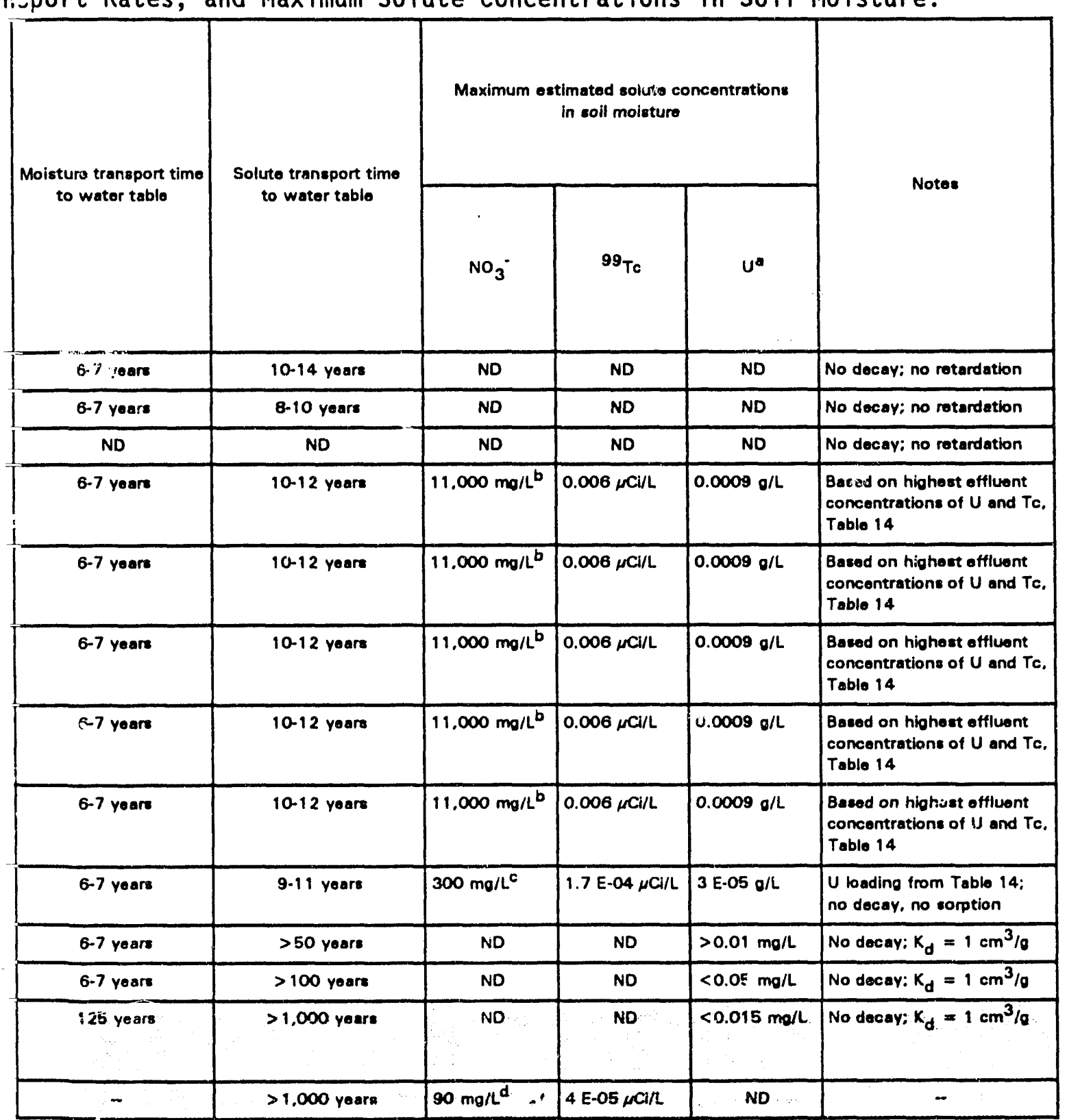

1 offluent (Trble 14) times the maximum nitrate concentration; i.e., $0.02 \times 15.200 \mathrm{mg} / \mathrm{L}=300 \mathrm{mg} / \mathrm{L}$ (eer note d).

216-U-17 Crib Ifrom WHC-EP-0367. Table 2.21-2; also soo Table 5 and Soction 6.1 for rolatod discuksion,. 
Table 8. Hydraulic Properties Used for Material Types (Zones).

\begin{tabular}{|c|c|c|c|c|c|c|}
\hline Zone & Borehole & $\begin{array}{c}\text { Depth } \\
(\mathrm{m})\end{array}$ & $\begin{array}{c}\alpha \\
(\mathrm{m})\end{array}$ & $n$ & $\begin{array}{c}K_{\text {Sat }} \\
(\mathrm{m} / \mathrm{yr})\end{array}$ & $\begin{array}{c}\text { Wetting/ } \\
\text { drying }\end{array}$ \\
\hline 1 & -- & -- & 0.0117 & 1.343 & 622.4 & $\mathrm{D}$ \\
\hline 2 & $2-W 10-13$ & 18.3 & 0.1287 & 1.6829 & 0.72 & $W$ \\
\hline 3 & $2-W 7-9$ & 3.1 & 0.431 & 1.1893 & 763.7 & $W$ \\
\hline 4 & $2-W 10-13$ & 24.4 & 0.0359 & 1.3713 & 8520.6 & $\mathrm{D}$ \\
\hline $5,6,8$ & $2-W 15-2$ & 30.5 & 0.0943 & 1.4734 & 39.5 & $W$ \\
\hline 7 & $2-W 15-16$ & 33.5 & 0.0731 & 1.2885 & 3471.3 & D \\
\hline 9 & $2-W 7-9$ & 21.0 & 1.7241 & 3.1449 & 26.1 & $W$ \\
\hline 10 & $2-W 7-9$ & 24.4 & 0.6803 & 1.1961 & 8.39 & $W$ \\
\hline 11 & $2-W 7-9$ & 26.8 & 0.6803 & 1.3972 & 16.38 & $W$ \\
\hline 12 & $2-W 7-9$ & 43.3 & 0.1133 & 2.3868 & 10.73 & $W$ \\
\hline 13 & $2-W 7-2$ & 67.1 & -- & -- & 852.06 & D \\
\hline
\end{tabular}

extends $100 \mathrm{~m}$ to both the east and west from the west end of the crib. The mean water table elevation is about 65 meters below ground surface. The model defines a 200-m-wide plane that is aligned longitudinally with the perforated pipe through the crib backfill. The numerical model is two-dimensional, including the idealized $200-\mathrm{m}$ plane, with a thickness $(\Delta y)$ corresponding to assumptions regarding the effective area of influx through the crib floor. The sedimentary layers from Figure 17 are approximated in the model by corresponding, rectangular-shaped regions or "zones" shown in Figure 33.

The stratigraphy from Figure 17 and the model domain in Figure 33 are similar to that used for the previous 216-U-17 Crib model (WHC 1990a). The previous model included the same stratigraphy but with less detai?, extended $500 \mathrm{~m}$ from west to east, and included the gravel backfill as a full layer from west to east. The present model represents the volume and lateral extent of the gravel backfill more accurately. The present model also includes gravel stringers (1ayers 3 and 8 [see Figure 17] as zones 3 and 7 [see Figure 33]). The three main layers of the early "Palouse" soil and Plio-Pleistocene unit are represented in both models, but with some differences in textural descriptions. In the unconfined aquifer, the upper Ringold and the main part of the Ringold Formation are differentiated for the present modei but not in the previous model. 
Figure 33. Idealized Longitudinal Cross Section of Stratigraphy Under the 216-U-17 Crib.

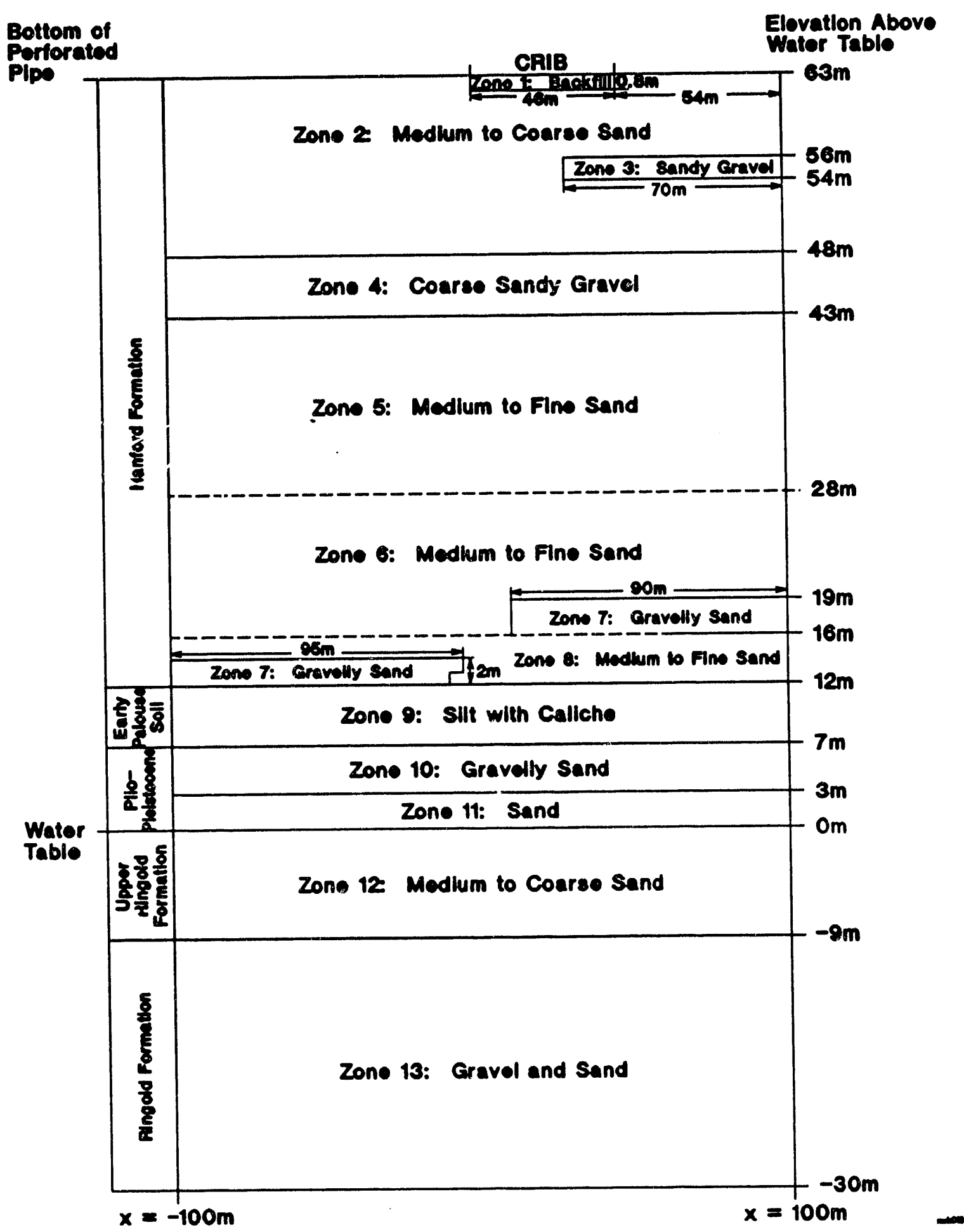




\subsubsection{Hydraulic, Soil, and Transport Properties}

Hydraulic properties for each zone in Figure 33 (except zone 1) were determined by matching tha textural descriptions of the layers (see Figure 17) with those of similar samples from boreholes in the 200 West Area and then assigning the sample properties (Connelly et al. 1992b) to the corresponding zone (see Table 8 ). The laboratory values of the two characteristic parameters ( $\alpha$ and $n$ ) for the soil moisture tension $(\psi)$ versus volumetric moisture content $(\theta)$ are determined following van Genuchten (1978). Relative hydraulic conductivity $\left(k_{r}\right)$ is calculated from the Mualem (1976) predictive model. The corresponding value of hydraulic conductivity at saturation $\left(K_{\text {sat }}\right)$ is also given in Table 8 . The last column in Table 8 indicates whether the characteristic curve for each zone is a wetting or drying curve. The unsaturated hydraulic conductivity is $K=K_{r} \cdot K_{\text {sat }}$ and is assumed to be isotropic (i.e., $K_{x}=K_{y}=K$ ), except as noted.

Wetting curves are used where available for accuracy in modeling wetting of the soil column and arrival of the wetting front at the water table. However, wetting curve data were not available for the gravel layers in the model (zones 3,7, and 13). The drying curve data used for the gravel backfill in the crib bottom (zone 1) are the same as used previously (WHC 1990a). In the previous model (WHC 1990a) drying curves were used exclusively because no wetting curve data were yet available; moreover, those drying curves were based on soil samples from the 200 East Area rather than the 200 West Area.

The saturated volumetric moisture content $\left(\theta_{\text {sat }}\right)$ and residual moisture content $\left(\theta_{\text {res }}\right)$ derived from the same samples are shown in Table 9 . These two quantities ( $\theta_{\text {sat }}$ and $\theta_{\text {res }}$ ) are not directly used in the numerical model, but are used to infer porosity. Total porosity $\left(\phi_{T}\right)$ is assumed to be the same volume fraction as $\theta_{\text {sat }}$. The residual moisture content is assumed to be indicative of deadend pore space, which does not contribute to flow. Therefore, the effective porosity $\left(\phi_{E}\right)$, which is the volume fraction that admits flow of fluid through the soif matrix, is taken to be $\theta_{\text {sat }}-\theta_{\text {res: }}$. It is further assumed that the entire pore space is well interconnected (i.e., contains no isolated pores). Thus, the diffusive porosity $\left(\phi_{D}\right)$, the effective flow porosity plus the connected deadend pore space that contains fluid and admits diffusion of solute, is taken to be equal to $\phi_{\mathrm{r}}$ (Table 10). The last column in Table 10 contains measurements/estimates of bulk density. Because the volumetric moisture contents of the various layers are not known but are assumed small (except in the aquifer), the bulk density is used as an estimate of soil density in computation of an effective retardation factor.

The base value of sorption coefficient $\left(K_{d}\right)$ is taken to be zero (i.e., unit retardation). The coefficient of molecular diffusion of solute in water is assigned $0.03 \mathrm{~m}^{2} / \mathrm{yr}$ for all cases. Base values of dispersivity are taken to be $1 \mathrm{~m}$ longitudinally and $10 \mathrm{~cm}$ transversely. These values of transport properties are consistent with those used in previous modeling work (WHC 1990a) and are used for all simulation cases reported here except as noted. 
Table 9. Volumetric Moisture Content Parameters for the 216-U-17 Crib Model.

\begin{tabular}{|c|c|c|}
\hline Zone & $\begin{array}{c}\text { Saturated } \\
\left(\theta_{\text {sat }}\right)\end{array}$ & $\begin{array}{c}\text { Residual } \\
\left(\theta_{\text {res }}\right)\end{array}$ \\
\hline 1 & 0.366 & 0.008 \\
\hline 2 & 0.342 & 0.023 \\
\hline 3 & 0.372 & -- \\
\hline 4 & 0.496 & 0.102 \\
\hline $5,6,8$ & 0.427 & 0.041 \\
\hline 7 & 0.372 & $0 . .9$ \\
\hline 9 & 0.449 & 0.06 \\
\hline 10 & 0.516 & -- \\
\hline 11 & 0.335 & -- \\
\hline 12 & 0.418 & 0.041 \\
\hline 13 & 0.262 & 0.088 \\
\hline
\end{tabular}

\subsubsection{Initial and Boundary Conditions}

Numerical simulations of vadose zone flow and transport to the unconfined aquifer were implemented with PORFLO-3, Version 1.2 (Runchal et al. 1992). The simulations are not a formal sensitivity analysis, but were designed to assess the importance of various parameters such as recharge rate, sorption coefficient, and initial gradient in the unconfined aquifer.

The simulations begin using a base case that is comparable to a previous model for the 216-U-17 Crib (WHC 1990a). Successive cases build on this base case using additional detail and variations of parameters. The final simulation runs represent an estimate case of actual conditions at the crib.

5.1.3.1 Flow Conditions. Each simulation begins with a steady-state flow field that is assumed to represent conditions at the beginning of operation of the 216-U-17 Crib on February 1, 1988. The steady flow field is first simulated without the presence of the crib backfill (i.e., zone 1 has the properties of zone 2). Each transient run begins on February 1, 1988 as a restart from a steady-state simulation, but includes crib backfill properties 
Table 10. Soil Properties Used for the 216-U-17 Crib Mode1.

\begin{tabular}{|c|c|c|c|c|}
\hline Zone & $\begin{array}{c}\text { Effective porosity } \\
\left(\phi_{E}\right)\end{array}$ & $\begin{array}{c}\text { Total porosity } \\
\left(\phi_{\mathrm{T}}\right)\end{array}$ & $\begin{array}{c}\text { Diffusive porosity } \\
\left(\phi_{D}\right)\end{array}$ & $\begin{array}{c}\text { Bulk density } \\
\left(\mathrm{kg} / \mathrm{m}^{3}\right)\end{array}$ \\
\hline 1 & 0.358 & 0.366 & 0.366 & 2,300 \\
\hline 2 & 0.319 & 0.342 & 0.342 & 1,800 \\
\hline $3^{\mathrm{a}}$ & 0.37 & 0.372 & 0.372 & 2,290 \\
\hline 4 & 0.394 & 0.496 & 0.496 & 2,200 \\
\hline $5,6,8$ & 0.386 & 0.427 & 0.427 & 1,800 \\
\hline 7 & 0.353 & 0.372 & 0.372 & 2,290 \\
\hline 9 & 0.389 & 0.449 & 0.449 & 1,500 \\
\hline $10^{a}$ & 0.51 & 0.516 & 0.516 & 1,700 \\
\hline $11^{a}$ & 0.33 & 0.335 & 0.335 & 2,140 \\
\hline 12 & 0.377 & 0.418 & 0.418 & 1,490 \\
\hline 13 & 0.174 & 0.262 & 0.262 & 1,500 \\
\hline
\end{tabular}

${ }^{a} \theta_{\text {res }}$ is effectively zero based on laboratory analysis of soil sample.

for zone 1 plus appropriate boundary conditions to drive the transient simulation.

For a prior steady-state flow simulation, the initial pressure heads in the vadose zone are estimated for a given recharge rate by material type (zone) using a unit gradient assumption (Khaleel and LeGore 1990). The initial vadose zone pressure head distribution is $P=Z+\psi$ where $z$ is the elevation above the original water table $(z=0)$ and $\psi$ is the approximate soil moisture tension for a given material type under a constant recharge rate. The recharge rate for the base case is assigned $q=10 \mathrm{~cm} / \mathrm{yr}$. The initial soil moisture tension by zone at that recharge rate is given in Table 11 . The initial flow conditions in the unconfined aquifer for the steady state are based on an assumed gradient. A value of $2 \times 10^{-4} \mathrm{~m} / \mathrm{m}$ (about a foot per mile) is used for the base case.

The boundary conditions for the steady-state case are consistent with the initial conditions. The top boundary is maintained at constant recharge rate $(10 \mathrm{~cm} / \mathrm{yr}$ ). The east and west ends (at $x= \pm 100 \mathrm{~m}$ ) are assigned a zero gradient, $\delta P / \delta X=0$, in the vadose zone. In the aquifer the initial values 
Table 11. Initial Soil Moisture Tension from Wetting Curves Based on $10 \mathrm{~cm} / \mathrm{yr}$ Recharge Rate.

\begin{tabular}{|c|c|c|c|}
\hline Zone & $\theta$ & $\begin{array}{c}\psi \\
(\mathrm{m})\end{array}$ & \multicolumn{1}{|c|}{ Remarks } \\
\hline 1 & -- & - & $\begin{array}{l}\text { Zone 1 (crib backfi11) is not included in } \\
\text { initial steady state }\end{array}$ \\
\hline 2 & 0.16 & -0.08 & \\
\hline 3 & 0.12 & -3.0 & \\
\hline 4 & 0.22 & -0.75 & Zone 4 is based on drying curve ${ }^{a}$ \\
\hline $5,6,8$ & 0.14 & -0.32 & \\
\hline 7 & 0.17 & -1.2 & Zone 7 is based on drying curve. \\
\hline 9 & 0.12 & -3.1 & \\
\hline 10 & 0.3 & -0.6 & \\
\hline 11 & 0.15 & -1.4 & \\
\hline 12 & $\theta_{\text {sat }}$ & 0 & Unconfined aquifer \\
\hline 13 & $\theta_{\text {sat }}$ & 0 & Unconfined aquifer \\
\hline
\end{tabular}

aetting curve data is not available for materials 4 and 7 .

remain fixed at the boundary for the steady state and for restarted transient simulaitions unless noted otherwise.

Although the model is two-dimensional, the PORFLO-3 code embodies an innately three-dimensional model. The "thickness" of the plane model is $\Delta y=1 \mathrm{~m}$ for the base case. This corresponds to an assumption that the width of the effective flow area of the trench floor is $1 \mathrm{~m}$. All influx of fluid at the top of the model is through a 1-m-wide strip, and incoming fluid is allowed to move only east, west, and vertically within the 1 -m-thick slice. outflow of fluid from the domain in the north and south directions is prevented by imposition of zero flux boundaries on the front and back faces of the domain.

Flow boundary conditions for the transient simulations of crib operation are the same as the boundary conditions used for the steady-state simulations with two main differences. First, for a transient case, influx is imposed at the top boundary according to an assumption regarding fiow to the crib from the $\mathrm{UO}_{3} \mathrm{Pl}$ ant. Secondly, in the vadose zone at $\mathrm{x}= \pm 100 \mathrm{~m}$, the boundary is switched from zero flux to specified head $(P=z)$ at any node that has become 
saturated $\left(\theta=\theta_{\text {sat }}\right)$. This allows drainage at the east and west sides, but only at saturation. All of the foregoing discussion of initial and boundary conditions for flow as well as the conditions for transport to be described below are summarized in Figure 34.

5.1.3.2 Transport Conditions. Simuiation of solute transport for all cases begins at the start of crib operation (February 1, 1988). Although the rate of discharge to the crib is low compared to crib capacity, the average rate of discharge over the operating life of the crib is substantially greater than recharge caused by infiltration of precipitation. Therefore, advection is assumed to be the dominant mode of solute transport initially. The east and west boundaries are accordingly zero diffusive flux boundaries to permit advection. The top boundary is set to zero concentration except for nodes representing the effective length of perforated pipe that admits effluent with a prescribed concentration of solute to enter the crib backfill. Other top boundary nodes that are within the overall length of the crib but are beyond the effective length of perforated pipe are set to zero diffusive flux. This prevents false diffusion from the crib. The bottom boundary $(30 \mathrm{~m}$ below the original water table) is assumed to be far enough removed from both the crib and the water table to be maintained at zero concentration. Zero flux conditions for fluid flow on the "front" (south face) and "back" (north face) of the model prevent advection of solute. For the transport equation, zero diffusive flux is prescribed on the front and back faces of the planar domain so that no transport of solute by any mode is allowed in the north and south directions.

\subsubsection{Simulation Cases}

In general PORFLO-3 (Runchal et al. 1992) embodies a finite volume-based model of fluid flow and solute transport in a variably saturated porous continuum. For the cases reported here, the implementation is with a pointcentered, central finite difference grid system. The central finite difference grid is composed of 58 nodes in the $x$-direction (west to east) and 66 nodes vertically. This grid is significantly more dense in terms of node spacing than that used for the previous flow model (WHC 1990a). The reduced node spacing accommodates increased detail in the stratigraphy, reduces numerical oscillatory wetting-drying observed in the previous model (WHC 1990a), and minimizes numerical dispersion in the solution of the solute transport equation.

The initial steady-state flow field was first simulated based on the assumed recharge rate of $q=10 \mathrm{~cm} / \mathrm{yr}$ before starting the base case simulations described below. The flow field is simulated in terms of pressure head and relative saturation (as opposed to volumetric moisture content, $\theta$ ). Relative saturation is a normalized moisture content defined as

$$
\theta^{*}=\frac{\theta-\theta_{r \theta s}}{\theta_{s a t}-\theta_{r \theta s}}
$$

Conceptually, relative saturation is the fraction of effective pora space which is occupied by the fluid (water). The steady-state relative saturation 
Figure 34. Summary of Boundary Conditions for PORFLO-3 Model of 216-U-17 Crib Operation.

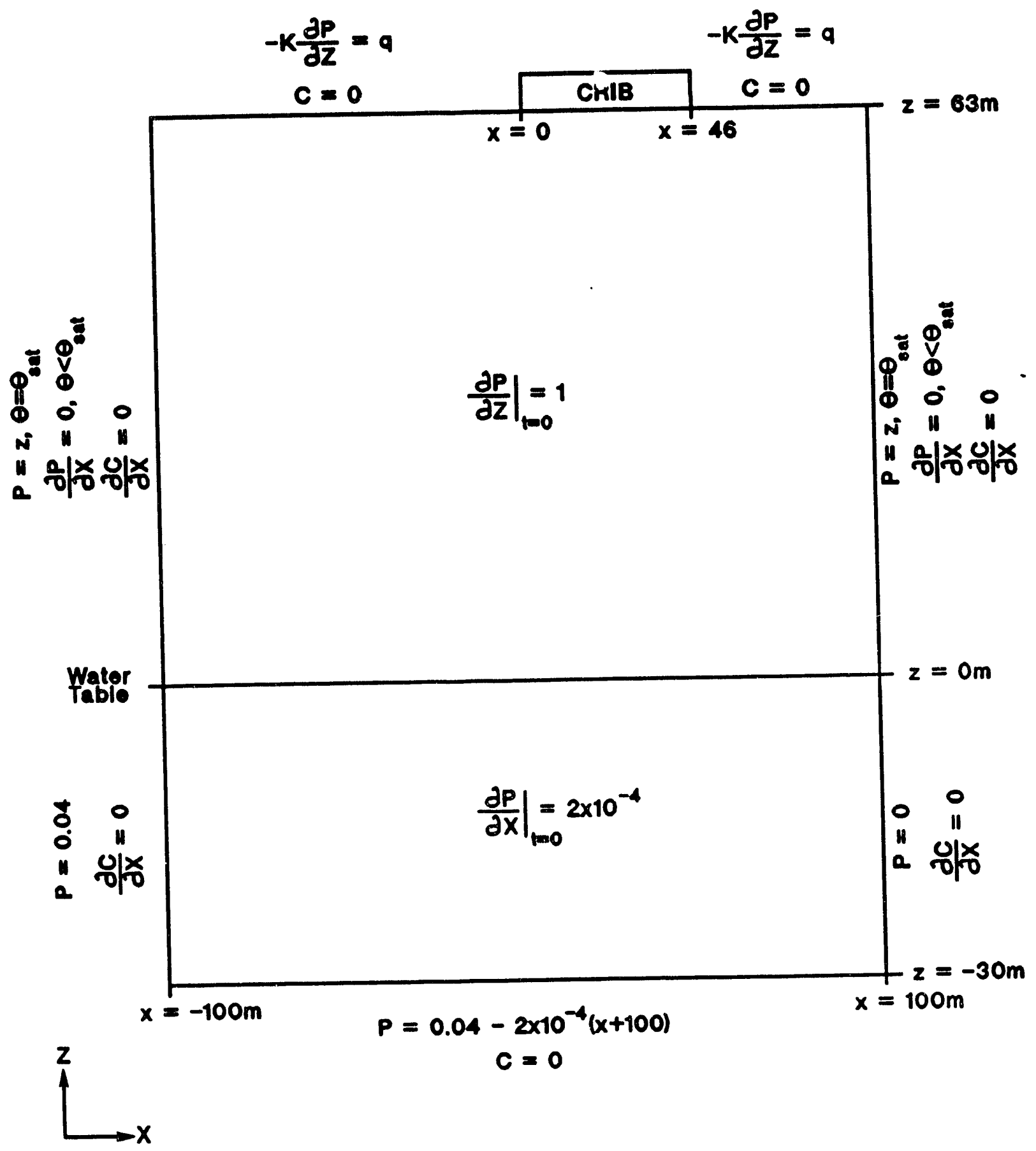


simulated from the starting conditions in Table 11 is shown in Figure 35 . The contour plot comprising Figure 35 and remaining plots of PORFLO-3 results were prepared with Version 5.0 of TECPLOT.

5.1.4.1 Base Case. Although there are some differences in stratigraphy, physical properties, and boundary conditions between the present model and the previous 216-U-17 Crib site model (WHC 1990a), the boundary conditions representing discharge of effluent to the crib for the present base case are identical to the previous mode1. Differences in results between the two are presumably due to the differences in stratigraphy and material properties used for simulation setup. For the present base case with $\Delta y=3 \mathrm{~m}$, a line source of length $20 \mathrm{~m}$ (from $x=0$ to $x=20$ ) with a constant discharge of $Q=2,190 \mathrm{~m}^{3}$ of fluid per year distributed uniformly over the assumed $60 \mathrm{~m}^{2}$ source area was applied to drive the model (identical to the source term used for case I in Appendix D of the Liquid Effluent Study Final Project Report [WHC 1990a]).

In the previous case (WHC 1990a), an almost fully saturated pathway from the crib to the original water table was established after about 17 years of simulated continuous discharge. In the present base case, after 1 year of simulation time the full length of the crib backfill (zone 1) is saturated and the gravel stringer (zone 3 ) in the upper sand layer of the Hanford formation has started to divert some flow to the east (Figure 36). After 3 years (Figure 37), the gravel stringer is nearing saturation at its west end but is still a barrier diverting flow to the east at its east end. As the gravel stringer saturates it becomes a preferential lateral pathway because of its relatively high saturated conductivity compared to the surrounding sand layer, zone 2 (see Table 8 ). The more extensive gravel layer, zone 4 , is another barrier to flow initially and an even more effective lateral conduit when wetted.

After 5 years, Figure 38 shows the combined effects of zones 3 and 4 diverting flow laterally; at the same time a broad plume (about $90 \mathrm{~m}$ ) of slightiy elevated moisture content extends to the bottom of the Hanford formation where some ponding is effected by the high air entry pressure $(\alpha)$ assigned to the early "Palouse" soil (zone 9). Figure 39 indicates breakthrough of the moisture front at the water table and the beginning of a mound within about 7 years. The preferential (saturated) pathway from the crib is laterally through the uppermost sand layer of the Hanford formation while the vertical pathway, which feeds the mound, is less than saturated and is diverted laterally further down the soil culumn by the gravel stringers near the bottom of the Hanford formation (zone 7) and the early "Palouse" soil and Plio-Pleistocene unit. Figure 40 suggests that even after 15 years the major conduits for flow are predominantly horizontal along bedding interfaces.

Transport of a soluble conservative species (i.e., no decay, no retardation) in terms of relative concentration was also simulated with the base case. Under the assumption of relative concentration, concentrations are simply fractional parts of the-original concentration of the species at the fluid source ( $i, e .$, relative concentrations can be used as "dilution factors"). Figure 41 shows relative concentration breakthrough curves at

${ }^{5}$ TECPLOT is a proprietary software product of Amtec Engineering, Bellevue, Washington. 
WHC-EP-0664

This page intentionally left blank. 
Figure 35. Simulation of 216-U.17 Crib

Base Case Steady State

Assumed Recharge Rate: $q=10 \mathrm{~cm} / \mathrm{yr}$

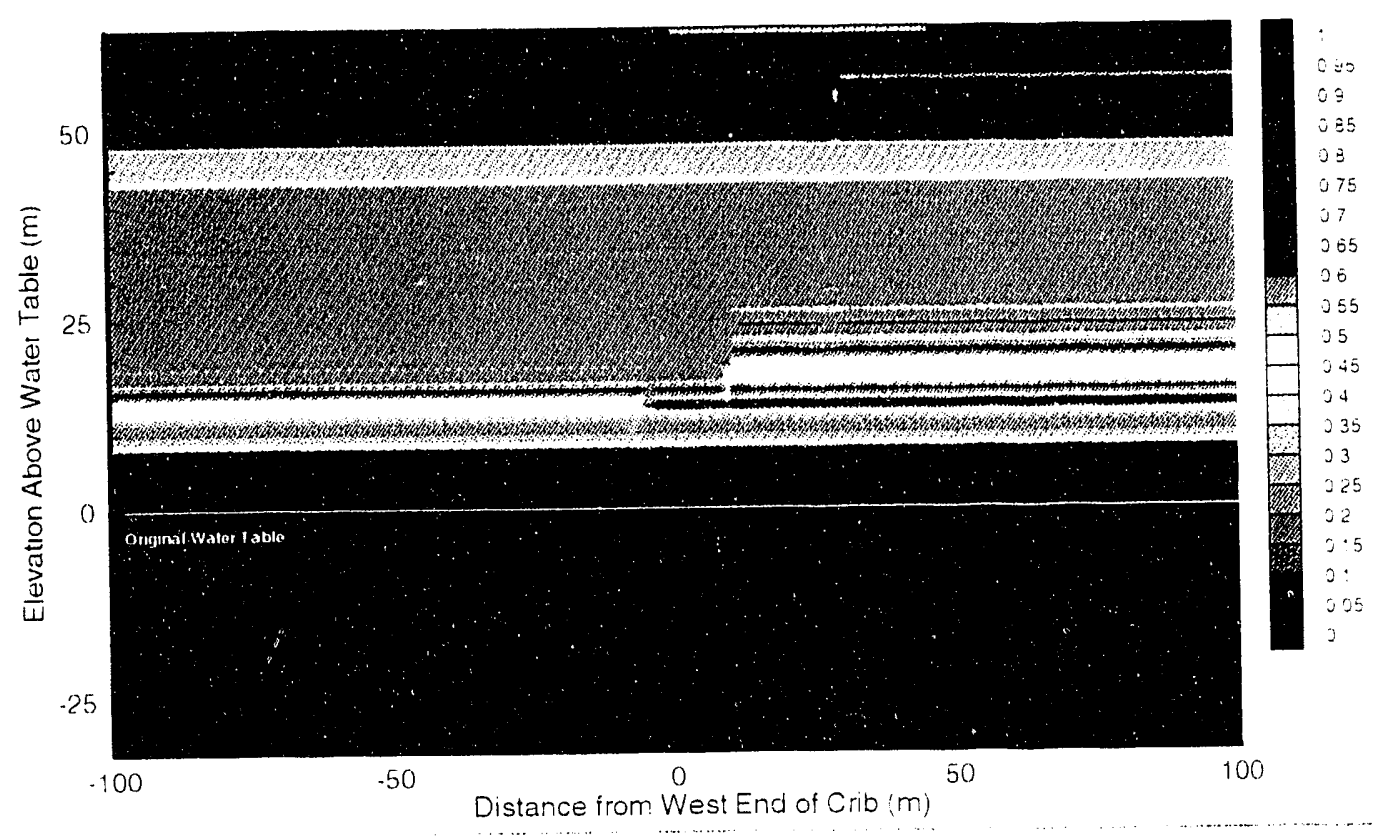

Figure 36. Simulation of 216-U-17 Crib Relative Saturation

Contours at 1 Year After Start of Crib Operation

Line Source, Thickness $=3 \mathrm{~m}, \mathrm{Q}=2190 \mathrm{~m}^{3} / \mathrm{yr}$

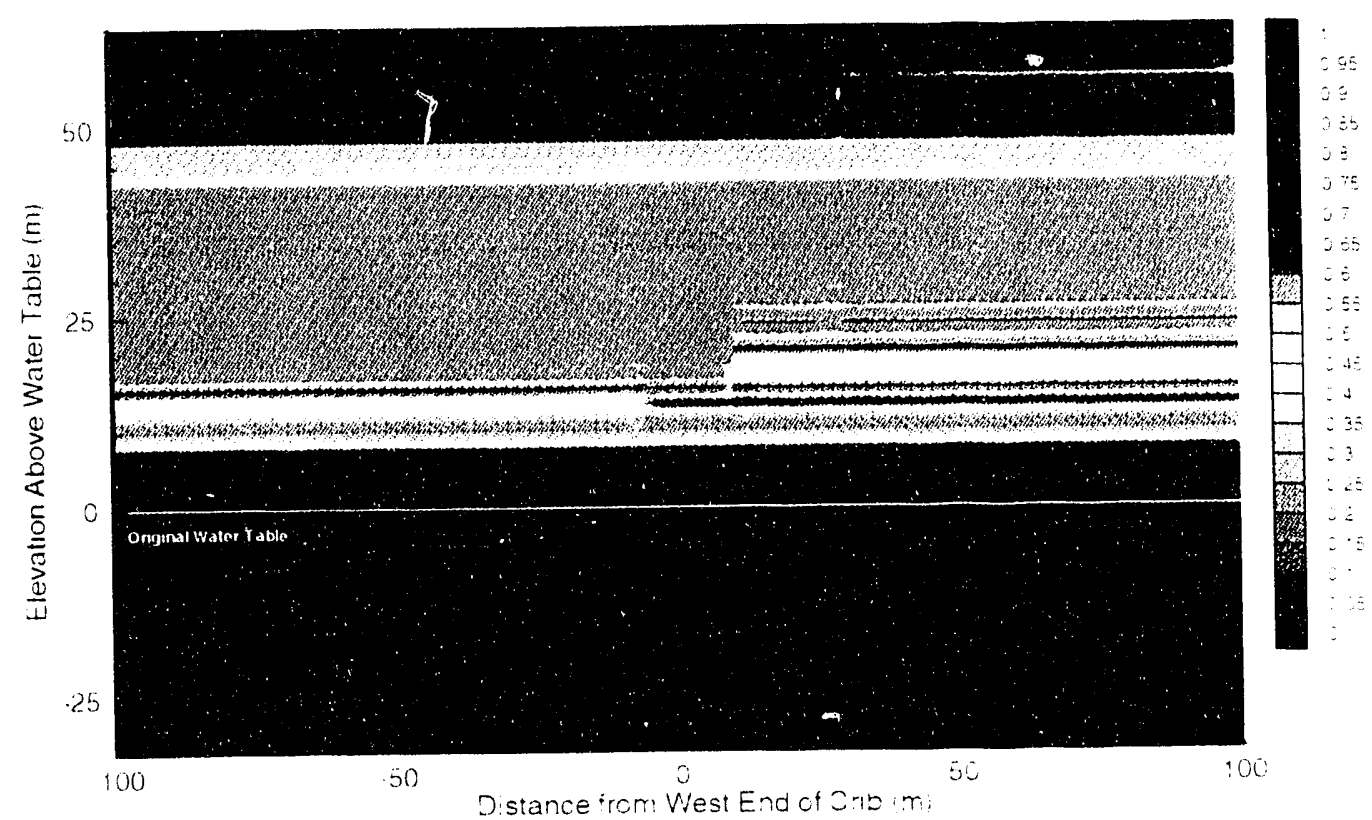

$75 / 76$ 
Figure 37. Simulation of 216-U-17 Crib Relative Saturation Contours at 3 Years After Stant of Crib Operation

Line Source, Thickness $=3 m, Q=2190 \mathrm{~m}^{3} / \mathrm{yr}$

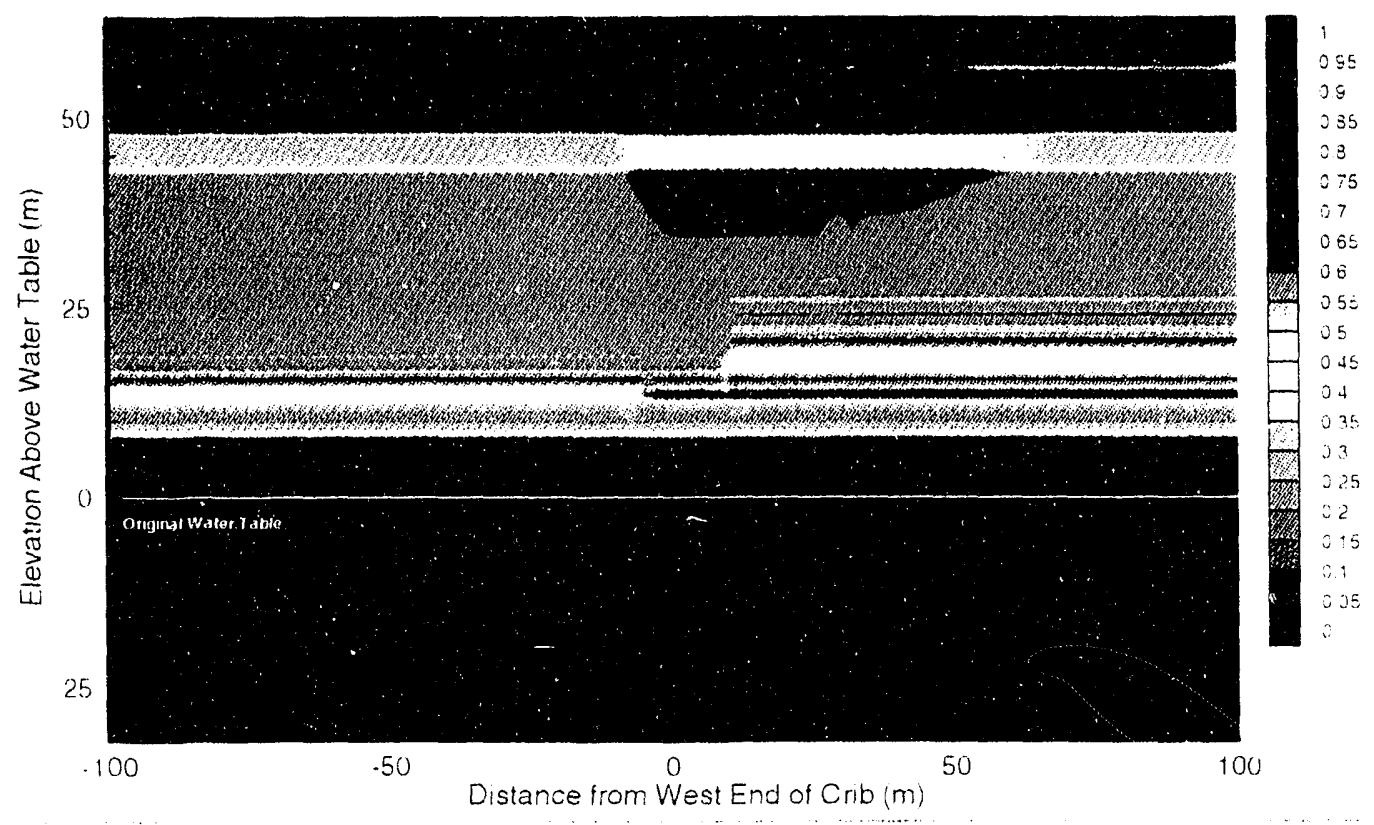

Figure 38 Simulation of $216-U-17$ Crib Relative Saturation Contours at 5 Years After Start of Crib Operation.

i. ne Source. Thickness $=3 \mathrm{~m}, \mathrm{Q}=2190 \mathrm{~m}^{3} / \mathrm{yr}$

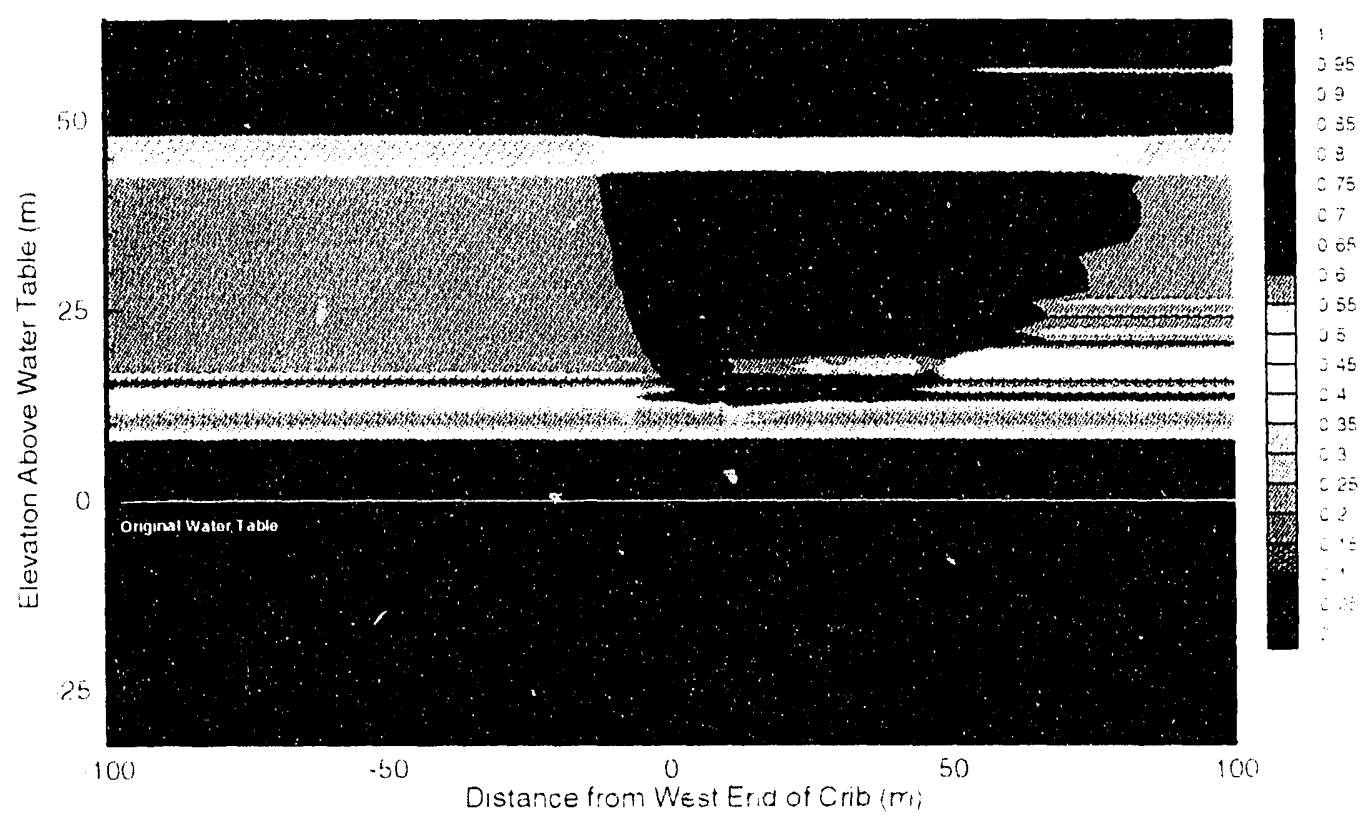

$77 / 78$ 
Figure 39 Sirnulation of 216-U-17 Crib Felative Saturation Contours at 7 Years After Start of Crib Operation

Line Source, Thickness $=3 m, Q=2190 \mathrm{~m}^{\prime} / \mathrm{yl}$

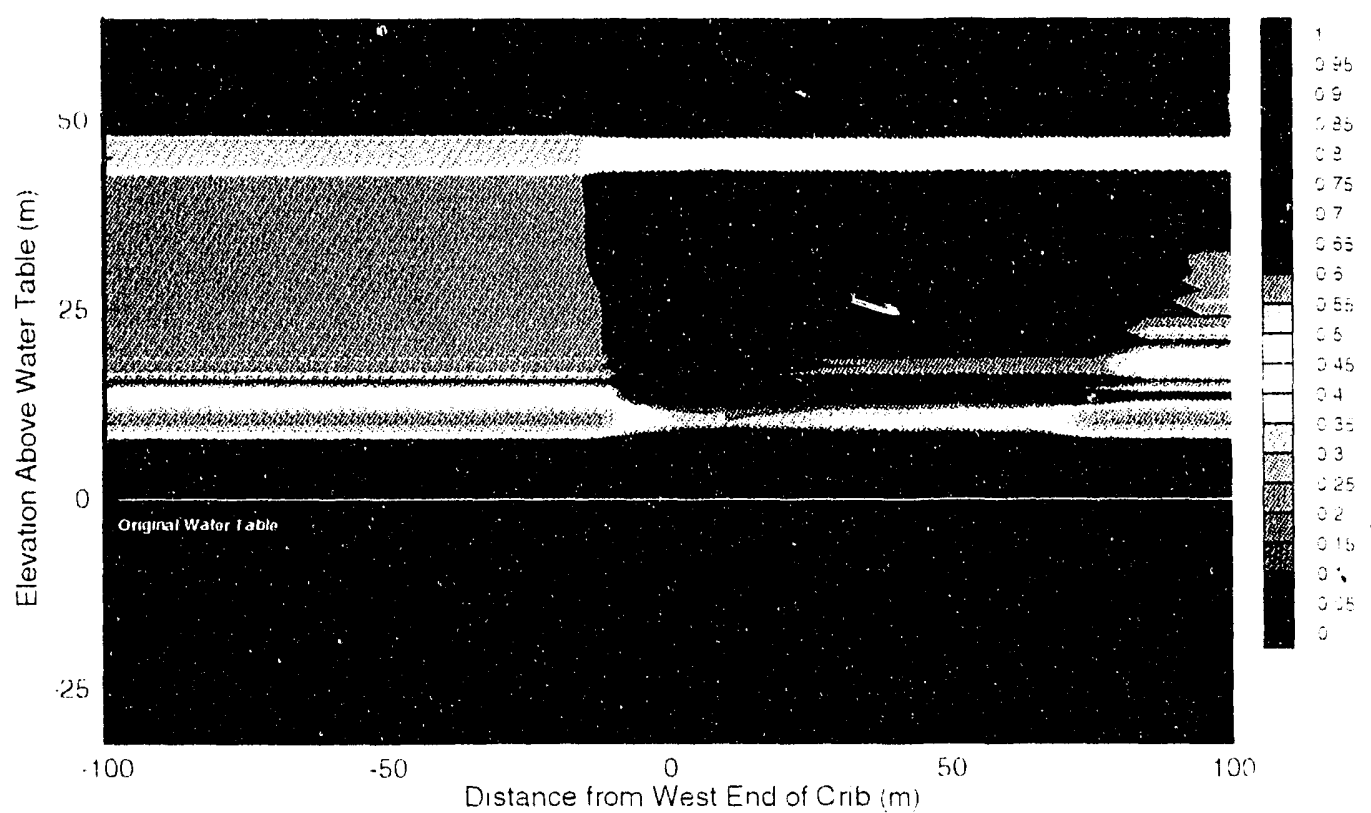

Figure 40. Simulation of 216-U-17 Crib Relative Saturation Contours at 15 Years After Start of Crib Operation

Line Source, Thickness $=3 \mathrm{~m}, \mathrm{Q}=2190 \mathrm{~m}^{3} \mathrm{yl}$

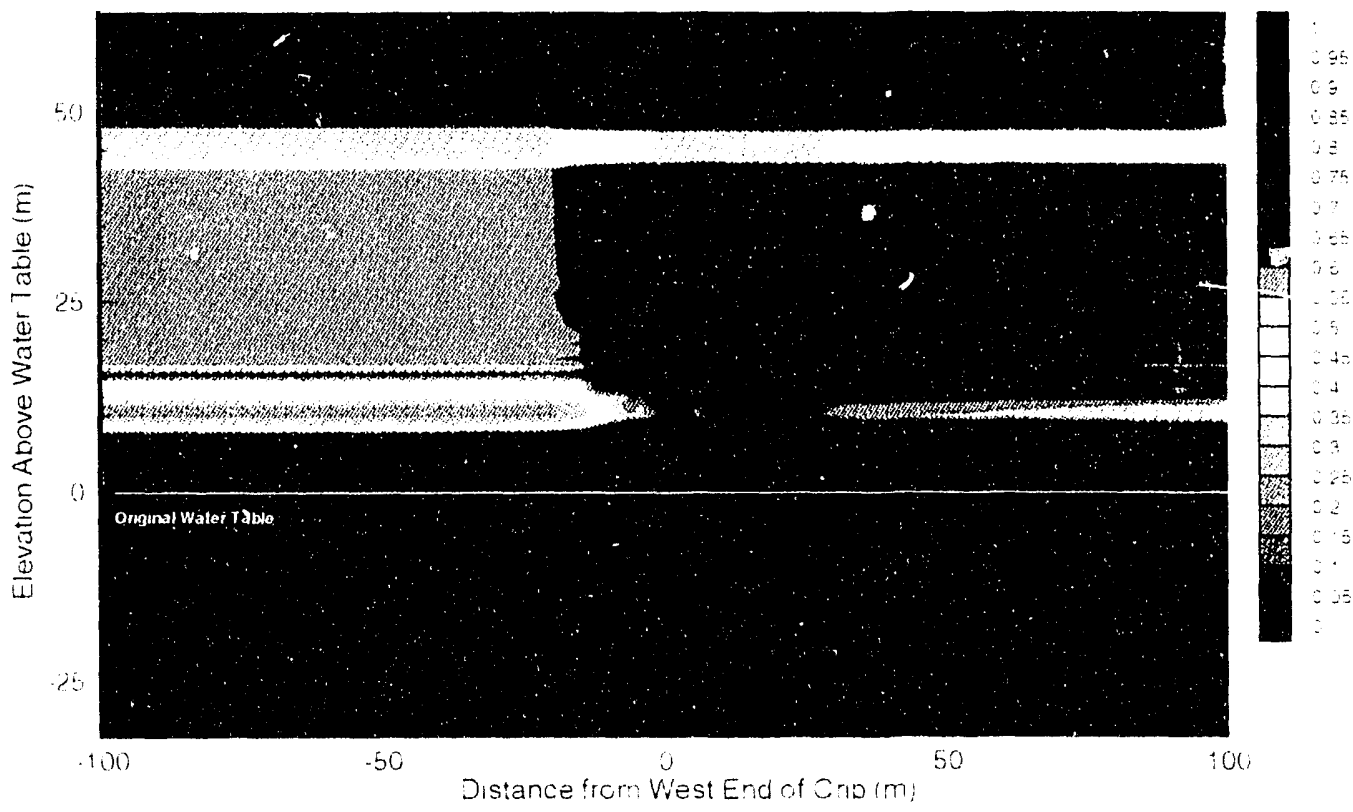

$79 / 80$ 


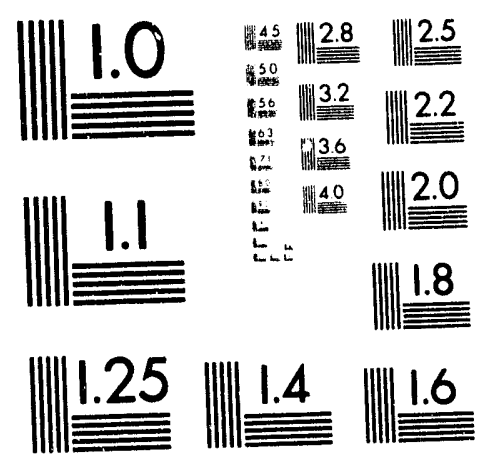



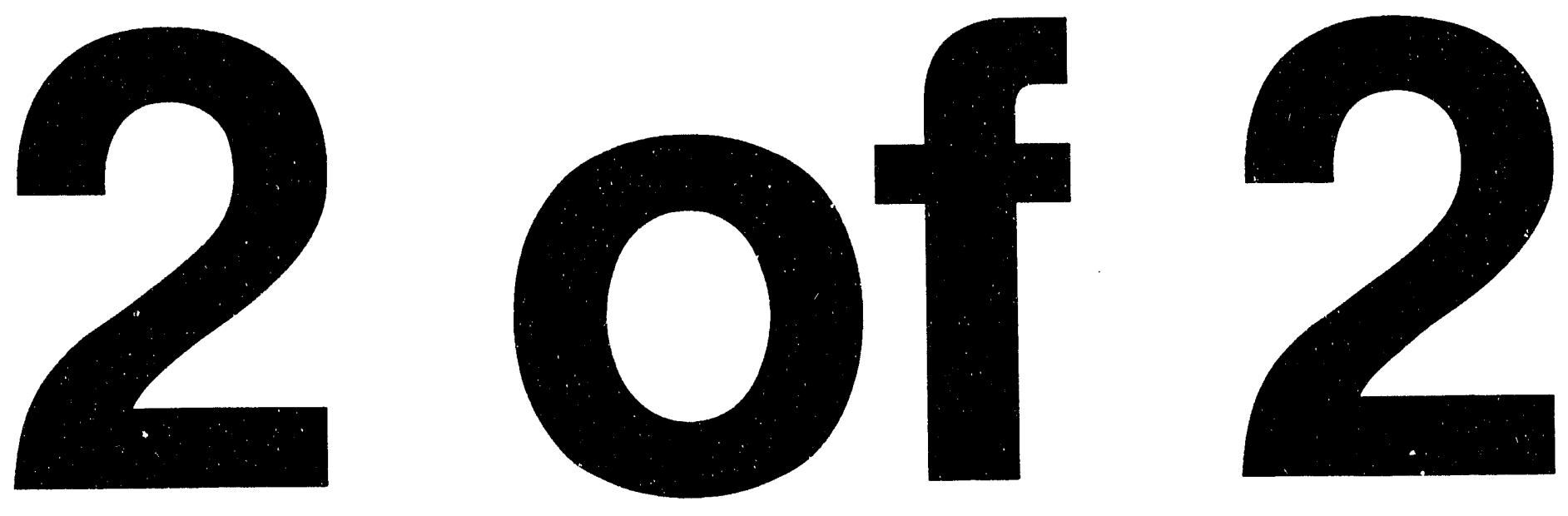
Figure 41. Simulation of 216-U-17 Crib - Base Case

Time History of Relative Concentration.

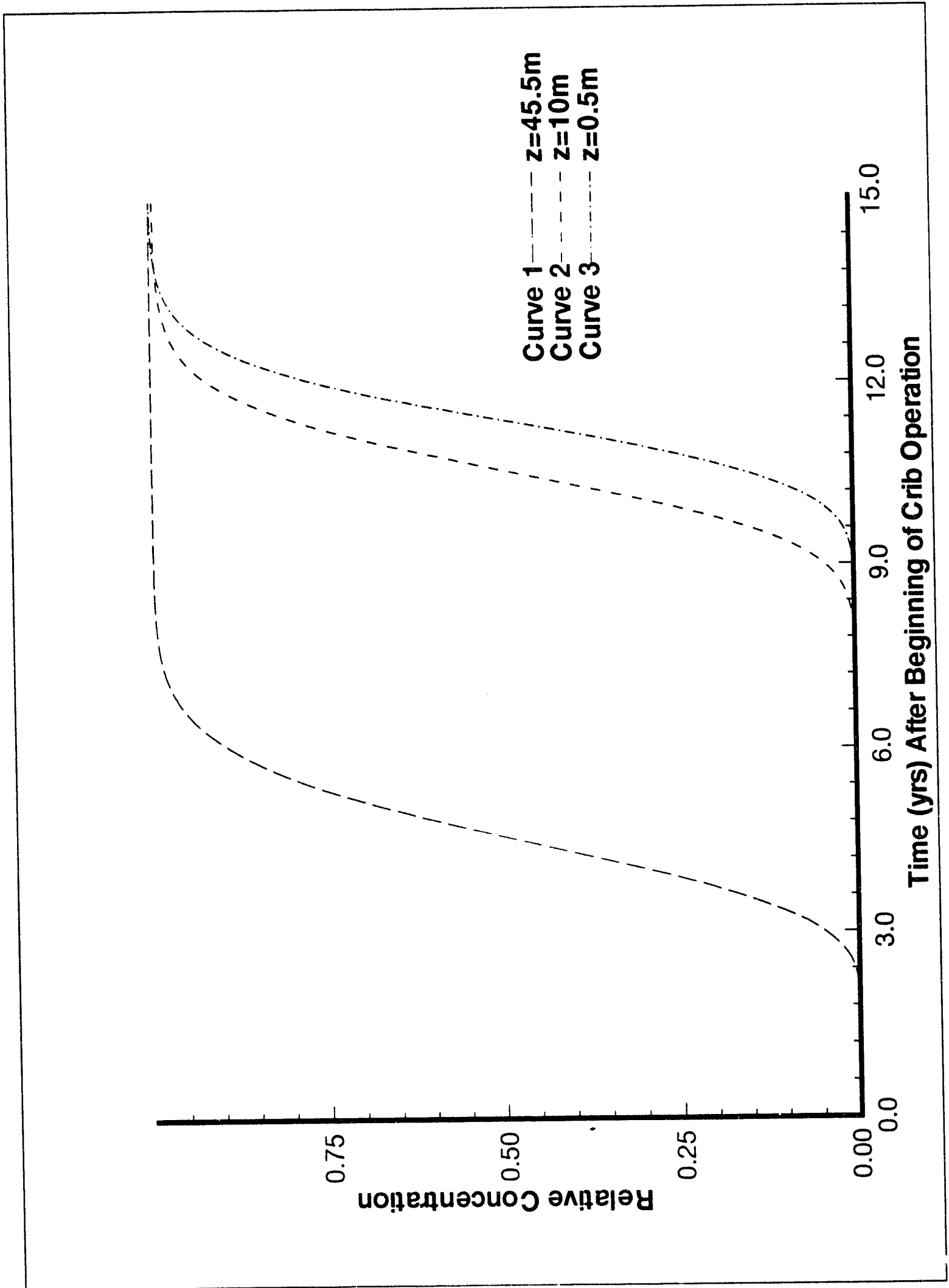


three elevations below the west end of the crib (at $x=0$ ) for the base case. Curve 1 (dot-dashed 1 ine) in Figure 41 indicates that $50 \%$ of the concentration in the prucess condensate discharged to the crib reaches an elevation of $45.5 \mathrm{~m}$ (zone 4 , coarse sandy gravel layer in the Hanford formation) above the original (1988) water table after about 4 to 5 years of continuous operation with a constant discharge rate of over $i$ gal/min. Curve 3 (solid line) shows that a relative concentration of only $5 \%$ arrives at the bottom of the PIioPleistocene unit during 10 years of continuous operation under the base case

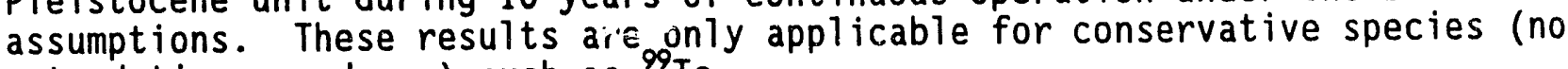
retardation, no decay) such as ${ }^{99} \mathrm{Tc}$.

The conservative base case model reported here is given as a means of benchmarking the present model against the previous, simplified flow model (WHC 1990a). Although the present model uses more detailed site-specific stratigraphy and physical property data derived from recent borehole samples taken from the 200 West Area, the results are not inconsistent with the previous results in the following respects:

- Both models indicate that the stratigraphy presents substantial barriers to vertical flow, and when wetted, the gravel layers become lateral conduits

- Both models indicate that even with continuous operation of the crib, a nearly saturated pathway to the water table evolves slowly over a period of at least 15 years.

5.1.4.1.1 Base Case With Unit Thickness. The above base case model was rerun with the domain having unit thickness (i.e., $\Delta y_{2}=1 \mathrm{~m}$ ). The assumption is that the $20-\mathrm{m}-1$ iong line source has an area of $20 \mathrm{~m}^{2}$ (i.e., effective width of the trench floor is $1 \mathrm{~m}$ rather than $3 \mathrm{~m}$ ). But the thickness of the full planar domain is only $1 \mathrm{~m}$ as well, and the same discharge of $2,190 \mathrm{~m}^{3} / \mathrm{yr}$ not only results in a tripled flux rate from the crib floor, but also results in faster migration through the soil column and shorter travel times.

For this variation of the base case, Figure 42 shows relative saturation contours at 3 years after start of crib operation. Compared to Figure 37 , lateral spreading in the upper layer of sand in the Hanford formation is more advanced, but vertical migration is not. After 5 years (Figure 43), some ponding is indicated in the gravel sand layer of the Plio-Pleistocene unit (zone 10). Breakthrough to the water table occurs within 7 years (Figure 44 ). Although iateral spreading to the east and west is enhanced and relative saturations under the crib are elevated due to the more restrictive northsouth lateral confinement $(\Delta y=1 \mathrm{~m})$, Figure 45 confirms that solute travel times are also shortened, but not by a factor of three. The primary effect on the model from further north-south confinement appears to be enhanced flow through the lateral conduits. For conservatism, unit thickness of the model domain $(\Delta y=1 \mathrm{~m})$ is maintained for further variations of the base case setup.

5.1.4.1.2 "Leaky" Boundary Conditions. The "leaky" boundary condition option in Version 1.2 of PORFLO-3 (Runchal et a1. 1992) was used in this model as described in Section 5.1.3.1 and summarized in Figure 34. Two minor variations of the base case (with $\Delta y=1 \mathrm{~m}$ ) were run to establish the importance of the flow boundary conditions at the east edge $(x=100 \mathrm{~m})$ and west edge $(x=-100 \mathrm{~m})$ of the vadose zone. In one case the leaky boundary was maintained on the east edge only while zero flux was imposed at the west; in 
Figure 42 Simulation of $216-U-17$ Crib-Base Case with

Unit Thickness - Relative Saturation Contours

at 3 Years After Start of Crib Operation

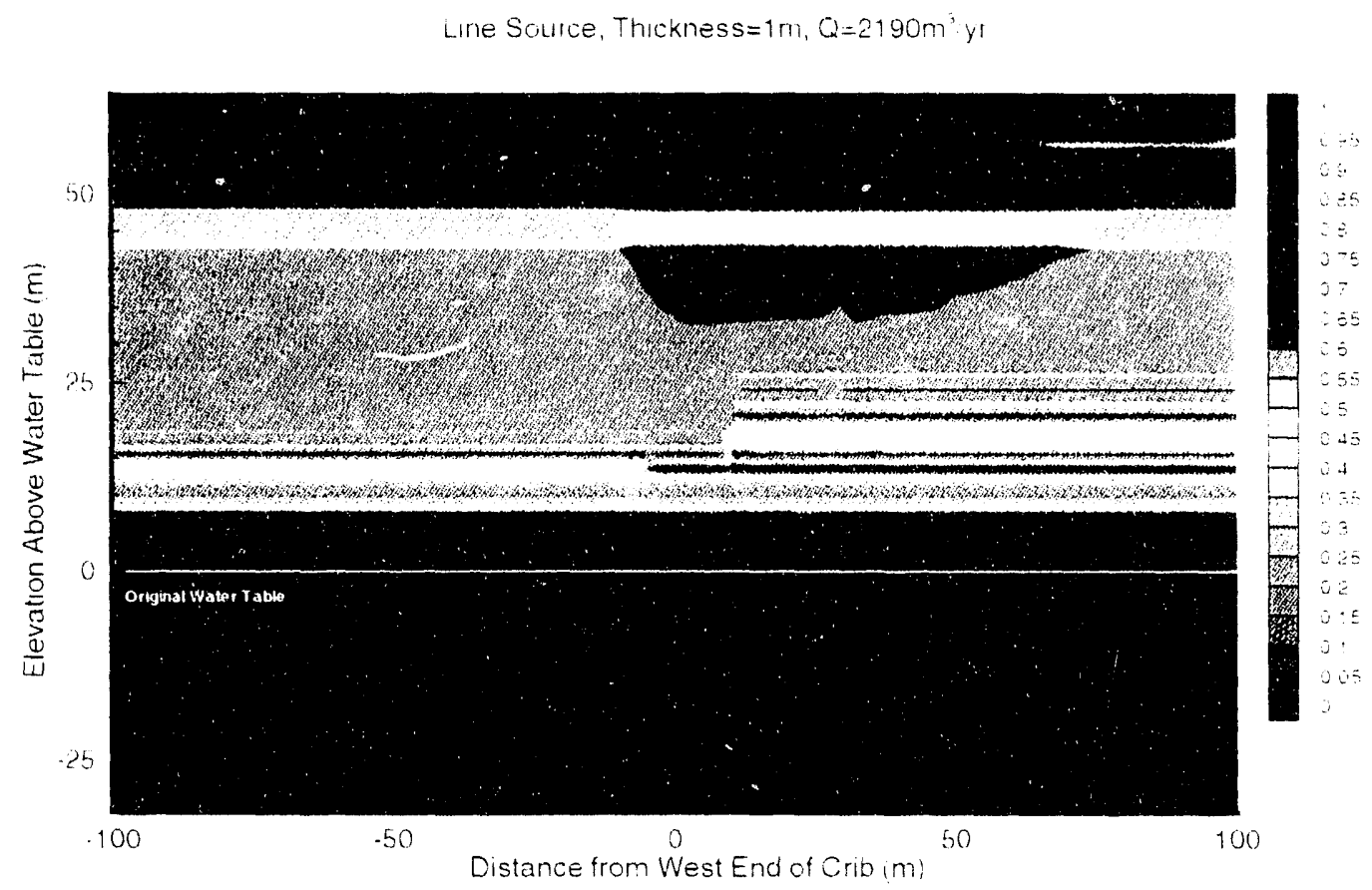

Figure 43. Simulation of 216-U.17 Crib - Base Case with Unit Thickness - Relative Saturation Contours at 5 Years After Start of Crib Operation.

Line Source, Thickness $=1 \mathrm{~m}, \mathrm{Q}=2190 \mathrm{~m}^{\mathrm{i}} \mathrm{yr}$

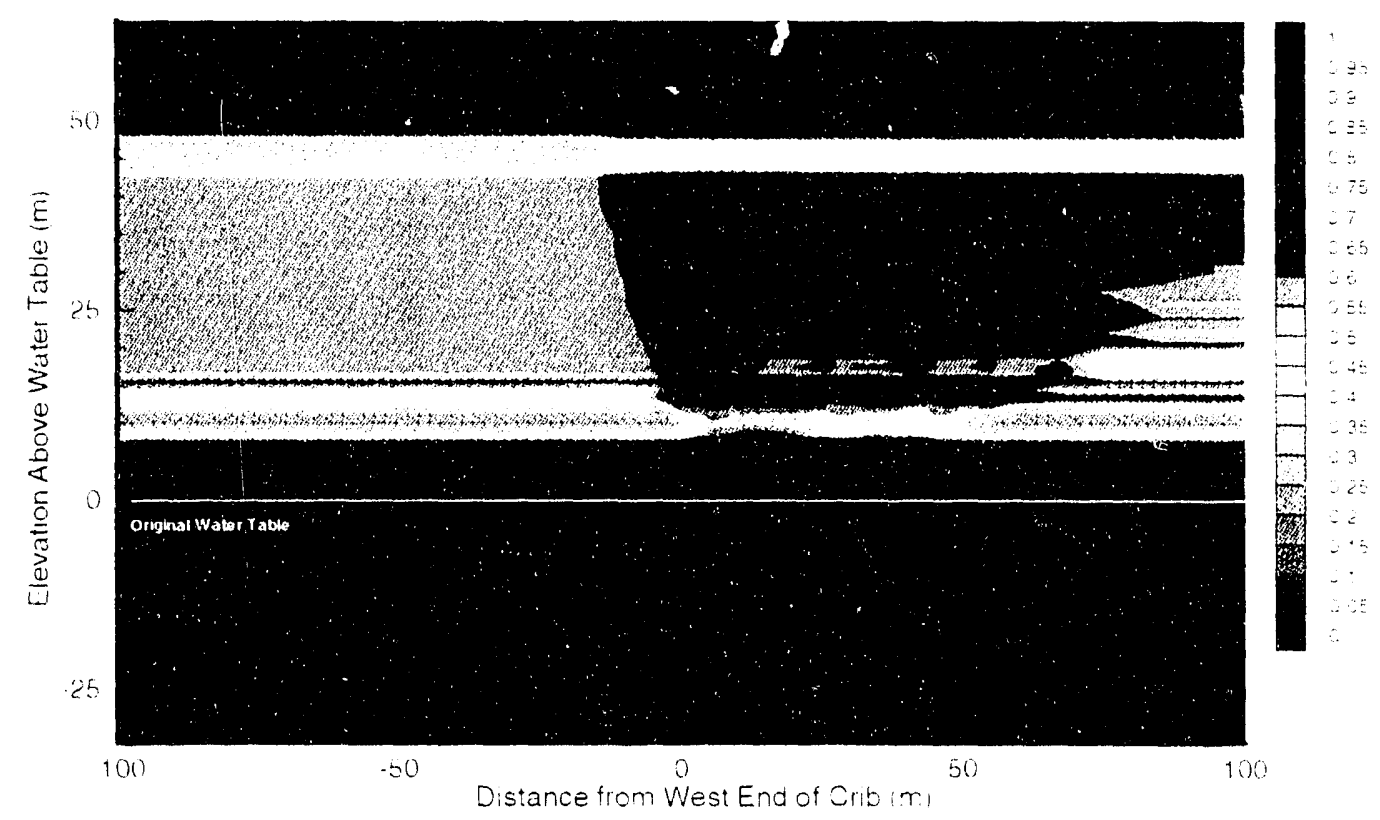

$83 / 84$ 
Figure 44. Simulation of 216-U-17 Crib-Base Case with Unit Thickness - Relative Saturation Contours

at 7 Years After Start of Crib Operation

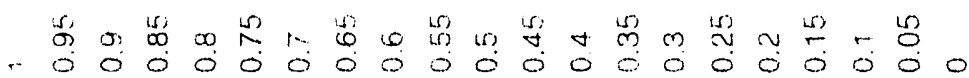

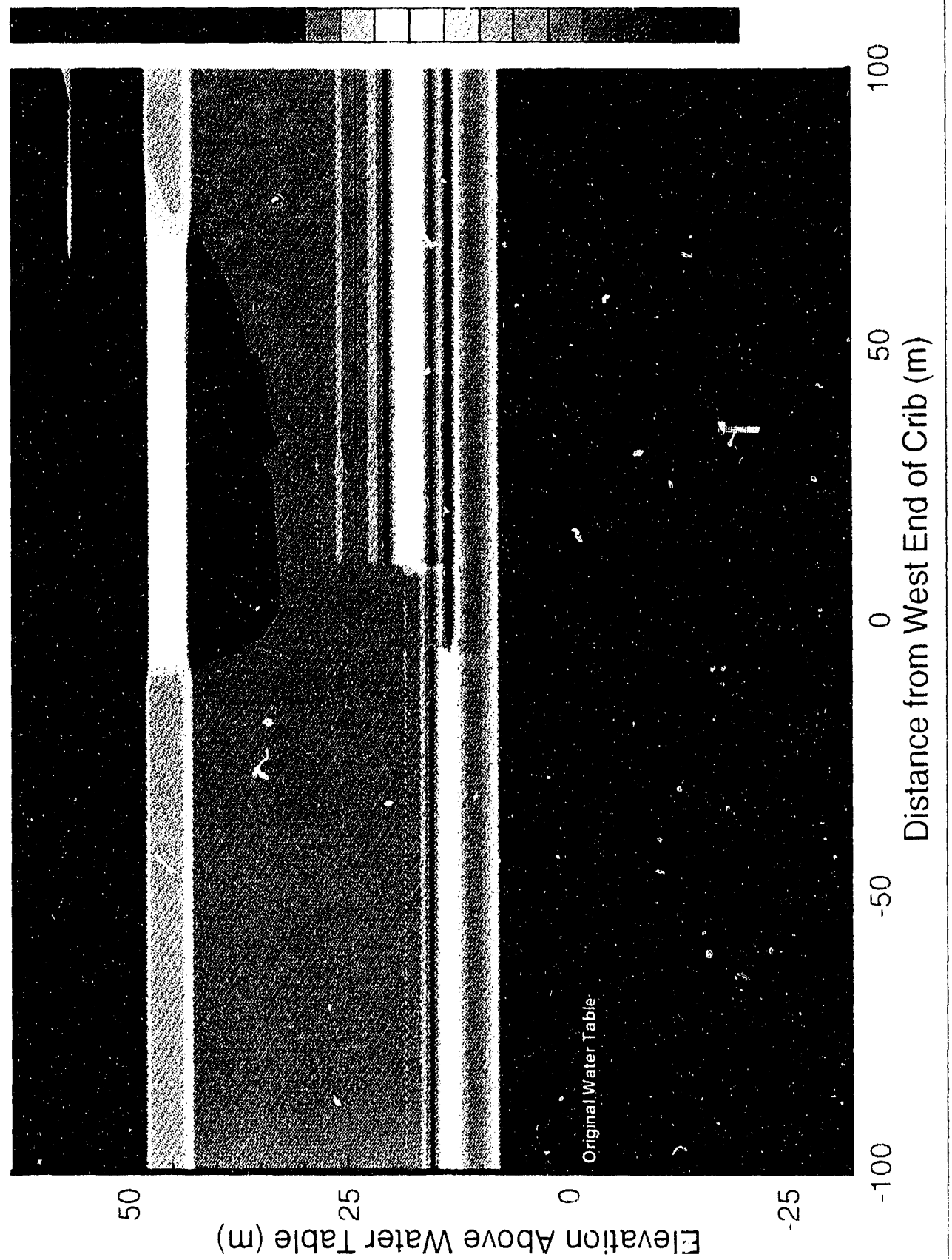


Figure 45. Simulation of 216-U-17 Crib - Base Case with Unit Thickness - Time History of Relative Concentration.

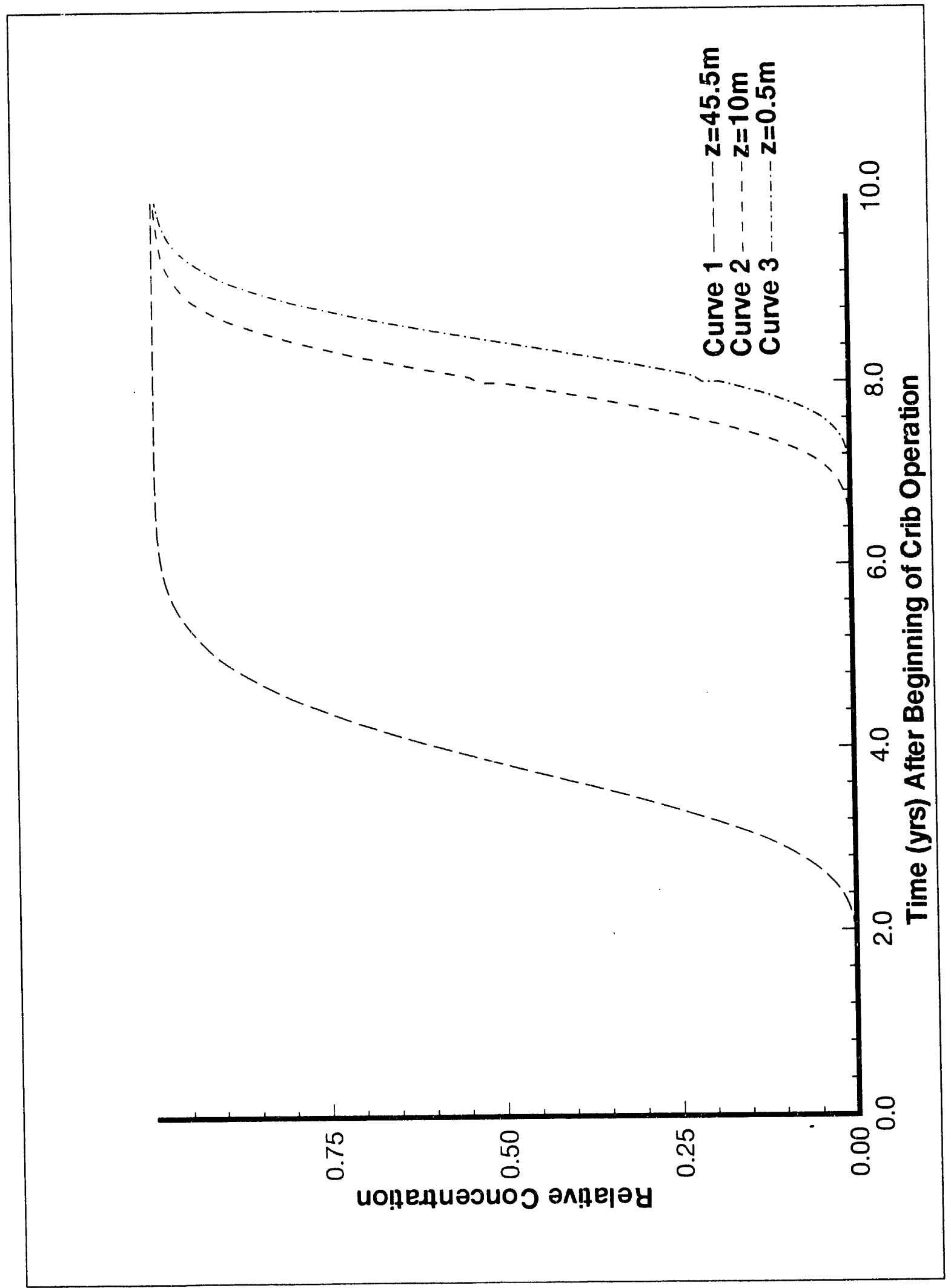


the other case, zero flux was imposed at both the east and west edges. The former was unremarkable because lateral flow is predominantly to the east due especially to the gravel stringer (zone 3) below the crib backfill. The latter showed some difference in relative saturation contours, particularly at the east boundary.

Relative saturation contours after 7 years of crib operation are shown in Figure 46 for the case with zero flux conditions for both the east and west edges of the vadose zone. In this case, more extensive ponding occurs in ti... Hanford formation with mouriding up into the early "Palouse" soil directly below the crib, compared to a "leaky" boundary, which shows somewhat less ponding and mounding. Figure 44, in particular, shows that saturation and subsequent desaturation caused by the leaky boundary condition occurred at the east end of the upper layer of the Hanford formation. For a larger scale model (i.e., with west and especially east boundaries further removed from the source), zero flux boundary conditions could appropriately be used to represent symmetry. For the remainder of the simulation cases, the model domain and the "leaky" boundary conditions (see Figure 34 ) are used because the zero flux boundary conditions in the vadose zone represent unnatural barriers.

5.1.4.2 Source Term Representation. The base cases described in the previous section and the previous model (WHC 1990a) are useful in qualitatively mapping plume development. However, for the 216-U-17 $\mathrm{Crib}$, an infinite source with continuous discharge at a constant rate is not an adequate representation of the source term for the purpose of approximating impact to groundwater. From this point forward the simulations are driven by fluid discharge boundary conditions that more accurately represent actual operation of the crib (see Tables 2, 3, and 4). The following three cases are identical derivatives of the base case (with $\Delta y=1 \mathrm{~m}$ and leaky boundary conditions on the vadose zone edges) driven by actual fluid discharges under three variations of the shape of the effective source region and distribution of the fluid to the soil over that region. Transport of conservative species in terms of relative concentration is also simulated.

5.1.4.2.1 Point Source. The point source is a $1-m$ by $1-m$ $(\Delta x=\Delta y=1 \mathrm{~m})$ square centered at $\mathrm{x}=0.5$ (the west end of the crib) on the upper surface (1-m-tnick edge) of the domain. For the initial operating period of the 216-U-17 Crib (February 1988 - June 1989), the total volume of radioactive liquid discharged to the crib $(557,000$ gal; see Table 4) was imposed on the point source at the time-averaged constant rate of about $1,485 \mathrm{~m}^{3} / \mathrm{yr}$. Relative concentration of conservative contaminant in the discharged fluid was set to unity as in preceding cases. Relative saturation contours for this case at June 30, 1989 are shown in Figure 47.

The moisture content distribution depicted in Figure 47 for this case is similar to previous base case results. This is not coincidental because the average discharge from February 1988 through June 1989 was about $1 \mathrm{gal} / \mathrm{min}$. The difference in fluid source terms is after June 1989. Whereas the original base case was driven by a continuous, effectively infinite source at a constant rate, the full fluid source term for this present case is summarized in Table 12. 
Figure 46. Simulation of 216-U-17 Crib-Base Case with Zero Flux Boundaries - Relative Saturation Contours at 7 Years After Start of Crib Operation.

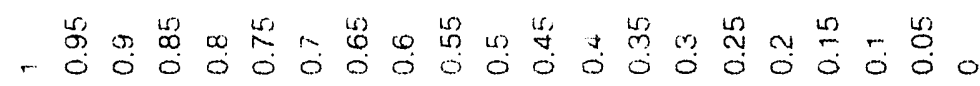
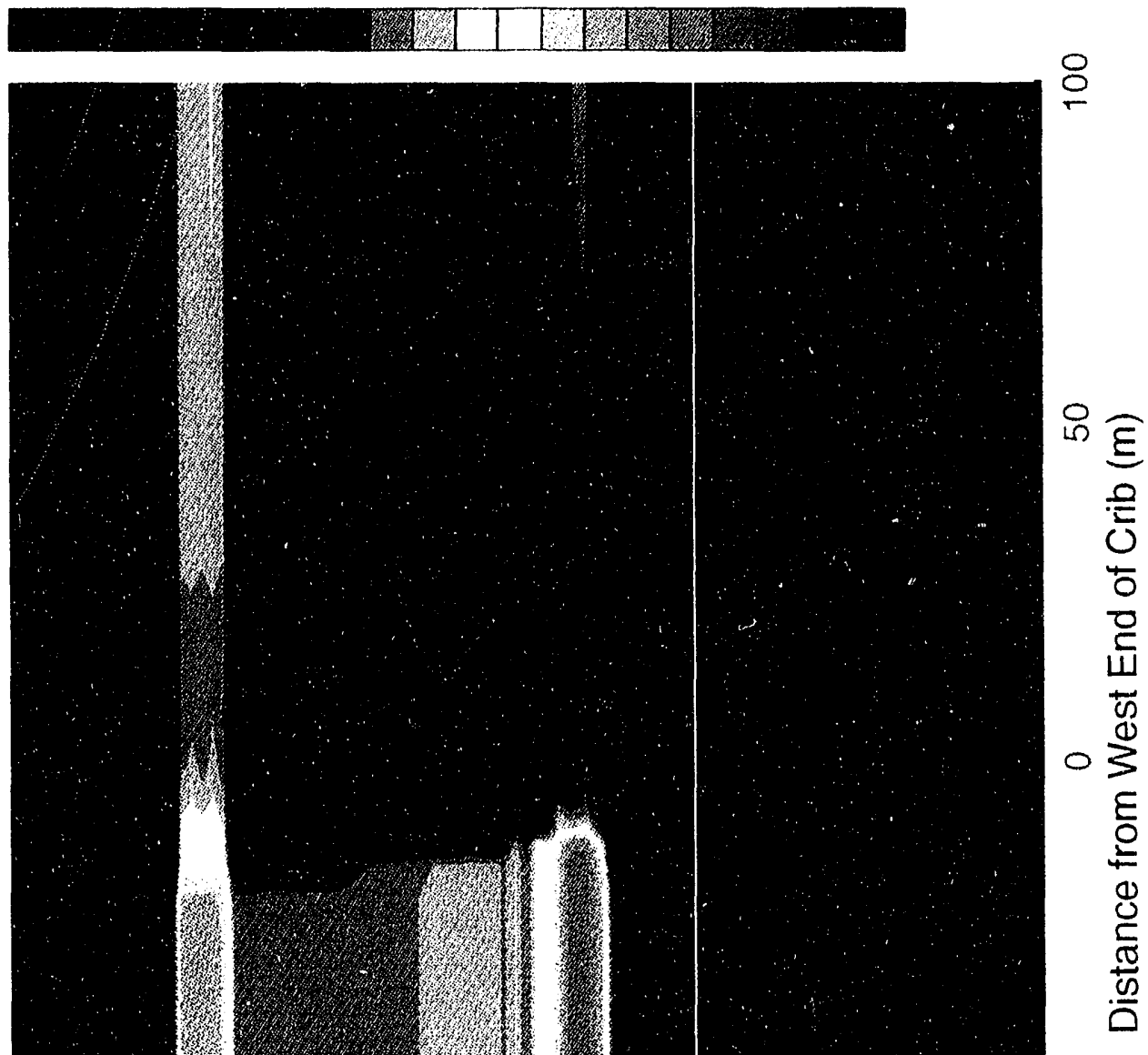

유

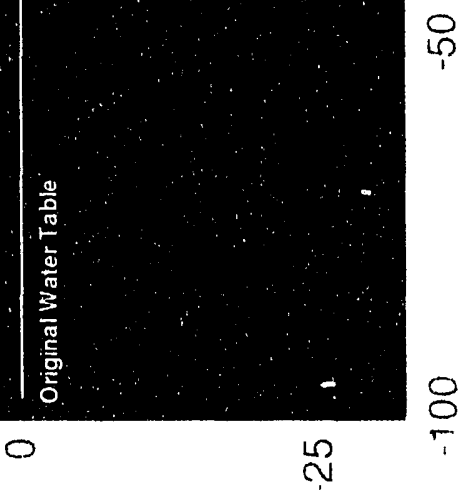

$\stackrel{\sim}{\sim}$



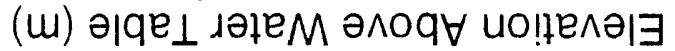


Figure 47. Simulation of 216-U-17 Crib - Point Source with Actual Gross Discharge - Relative

Saturation on June 30, 1989

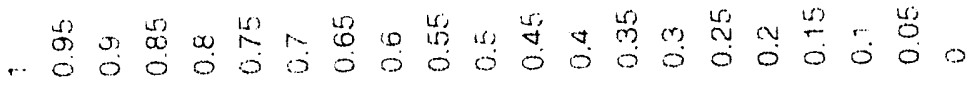
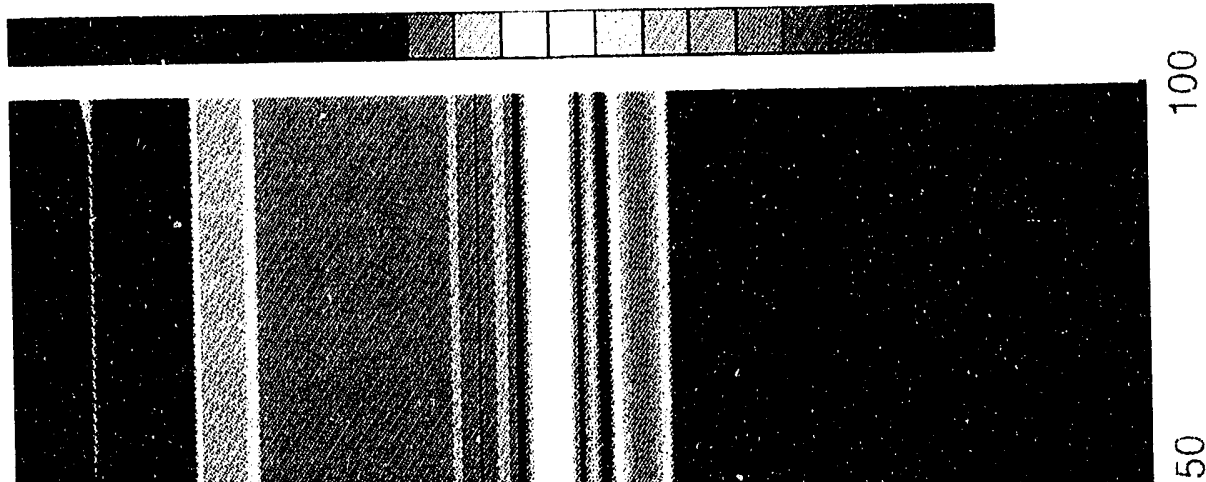
Table 12. Gross Actual/Planned Fluid Discharge.

\begin{tabular}{|c|c|c|c|}
\hline Volume (gal) & From & Through & Duration (months) \\
\hline $5.57 \mathrm{E}+05$ & $2 / 88$ & $6 / 89$ & 17 \\
\hline 0 & $7 / 89$ & $7 / 92$ & 37 \\
\hline $2.43 \mathrm{E}+05$ & $8 / 92$ & $12 / 92$ & 5 \\
\hline $1.75 \mathrm{E}+06$ & $1 / 93$ & $6 / 95$ & 30 \\
\hline 0 & $7 / 95$ & - & $\infty$ \\
\hline
\end{tabular}

Discharges shown in Table 12 for the period of time from August 1992 through June 1995 are based on ear'ly estimates of startup time and planned discharges for run 17 from the $\mathrm{UO}_{3} \mathrm{Plant}$ and following standby operation. The simulated relative saturation distribution in the soil column resulting at June 30, 1995 from the fluid discharges in Table 12 (Figure 48) is also suggestive of previous results. Relative concentration breakthrough curves for this case (Figure 49) indicate that arrival of peak relative concentration at the bottom of the Plio-Pleistocene unit occurs about 12 years after startup of the crib. These results are also similar to previous results. The importance of this case is indicated by curve number 1 (Figure 49), which suggests that after cessation Jf crib operation in 1995, contaminants (even conservative species) may reside for prolonged periods in the Hanford formation.

5.1.4.2.2 Nonuniform Line Source. In contrast to the point source and uniform short $(20-\mathrm{m})$ line source, a full-length line source $(46 \mathrm{~m})$ was used to represent discharges to the crib backfill. For the first implementation of the line source, the discharge of fluid was most heavily weighted to the west end of the crib. Cumulative percentages of discharges and corresponding cumulative distance along the perforated pipe in the backfill as assumed for simulation input are shown in Table 13.

Relative saturation contours for this case on June 30,1989 and June 30, 1995 are shown in Figures 50 and 51 , respectively. Comparison of Figures 50 and 51 to Figures 47 and 48 for the point source demonstrates that the model is insensitive to spatial representation of the source term. The physical interpretation is that the gravel backfill is another preferential lateral conduit.

5.1.4.2.3 Uniform Line Source. The model was also run with the fulllength $(46-\mathrm{m})$ line source, but with discharge distributed uniformly along the source. Figures 52 and 53 show relative saturations obtained on June 30, 1989 and June 30, 1995, respectively. These results further indicate that the model is insensitive to spatial representation of the source term; as a modeling convenience, the point source is used for the remainder of the cases. 
WHC-EP-0664

This page intentionally left blank. 
Figure 48. Simulation of 216-U-17 Crib - Point Source with Actual Gross Discharge - Relative

Saturation on June 30, 1995

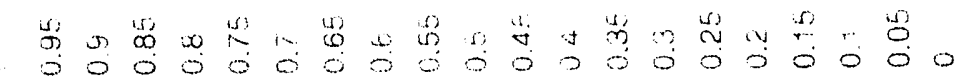

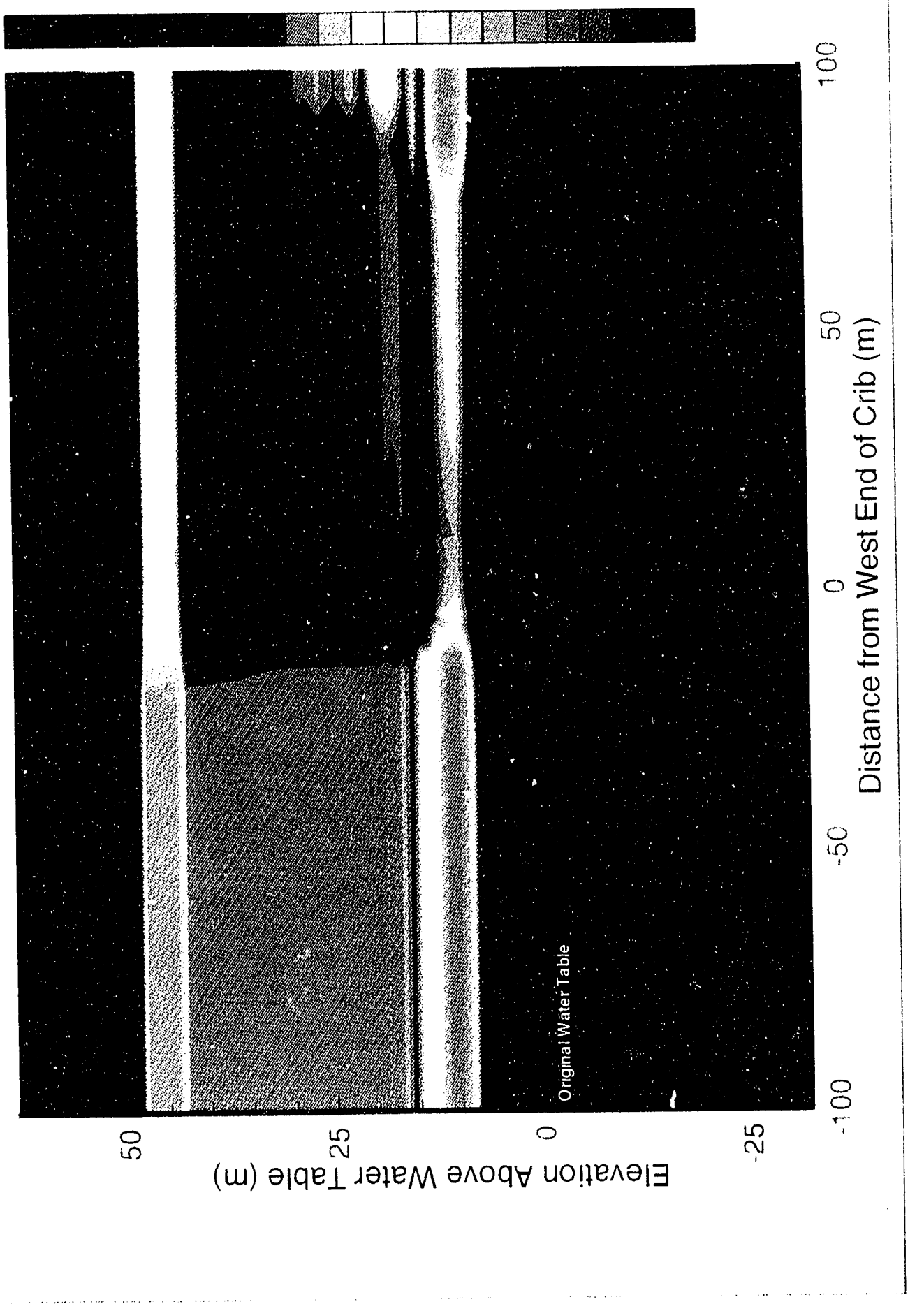


Figure 49. Simulation of 216-U-17 Crib - Point Source with Actual Gross Discharge - Time History of Relative Concentration.

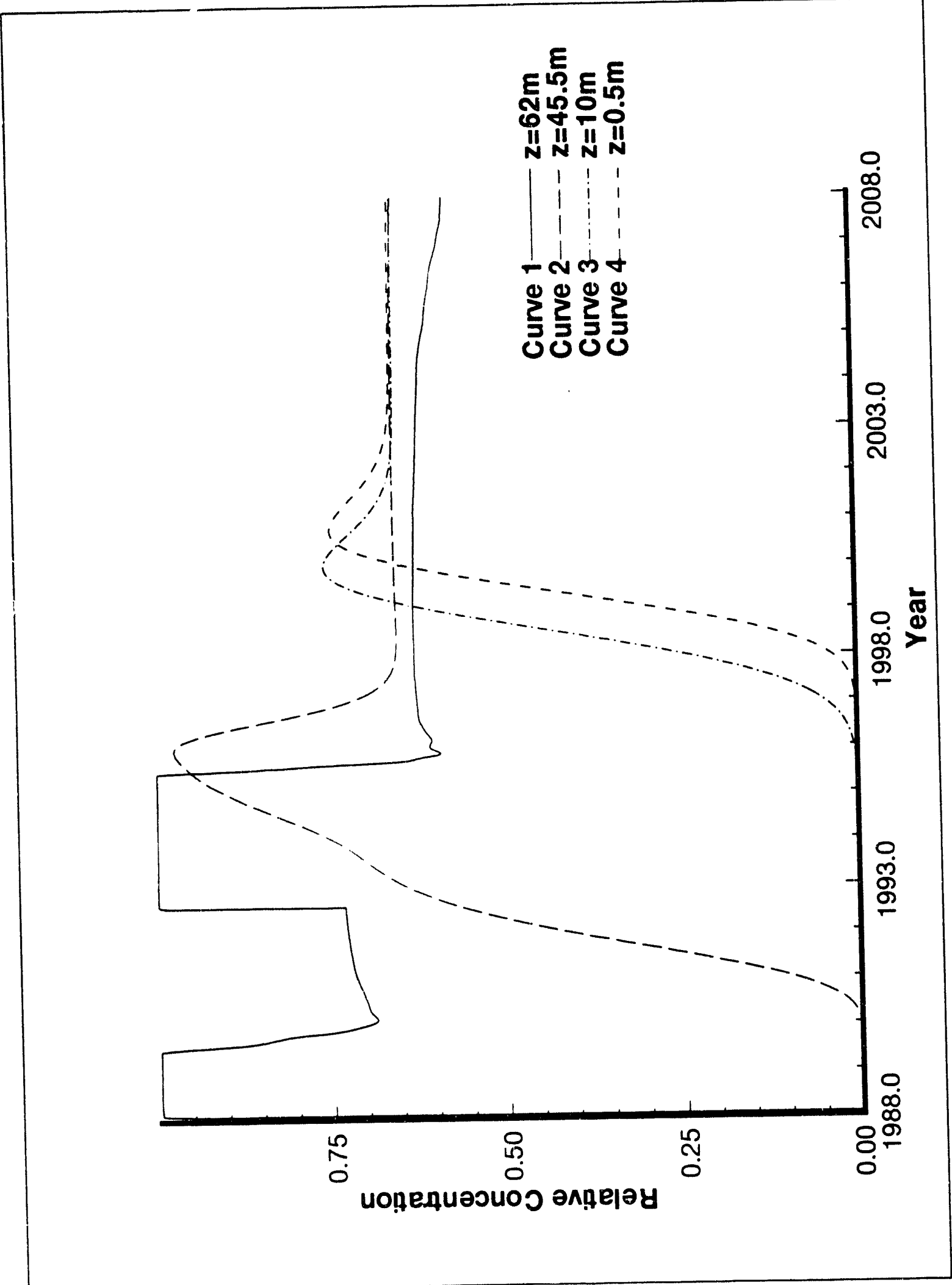


WHC-EP-0664

This page intentionally left blank. 
Figure 50. Simulation of 216-U-1/ Crib - Nonunitorm Line

Source with Gross Actual Discharge - Relative

Saturation on June 30, 1989

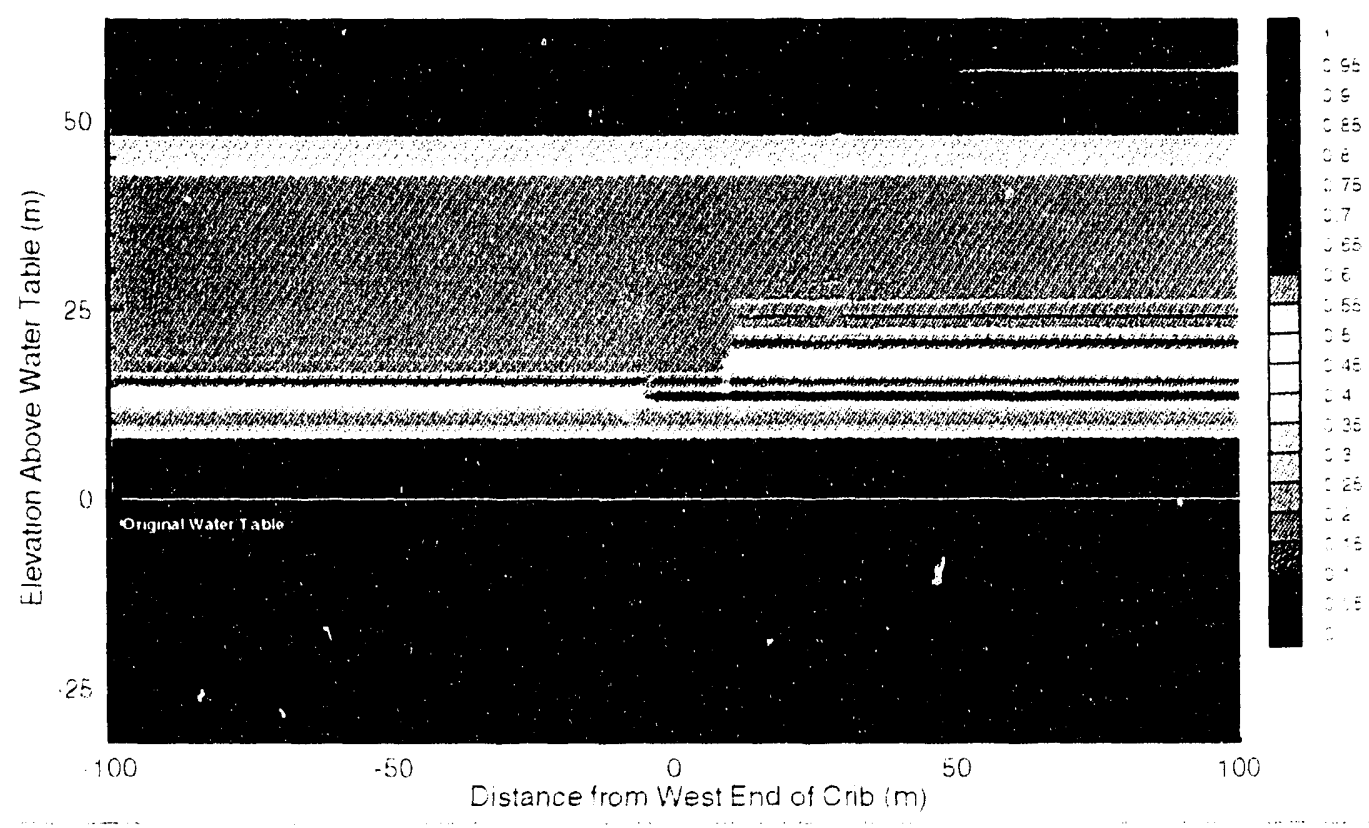

Figure 51. Simulation of 216-U-17 Crib - Nonuniform Line Source with Gross Actual Discharge - Relative Saturation on June 30, 1995

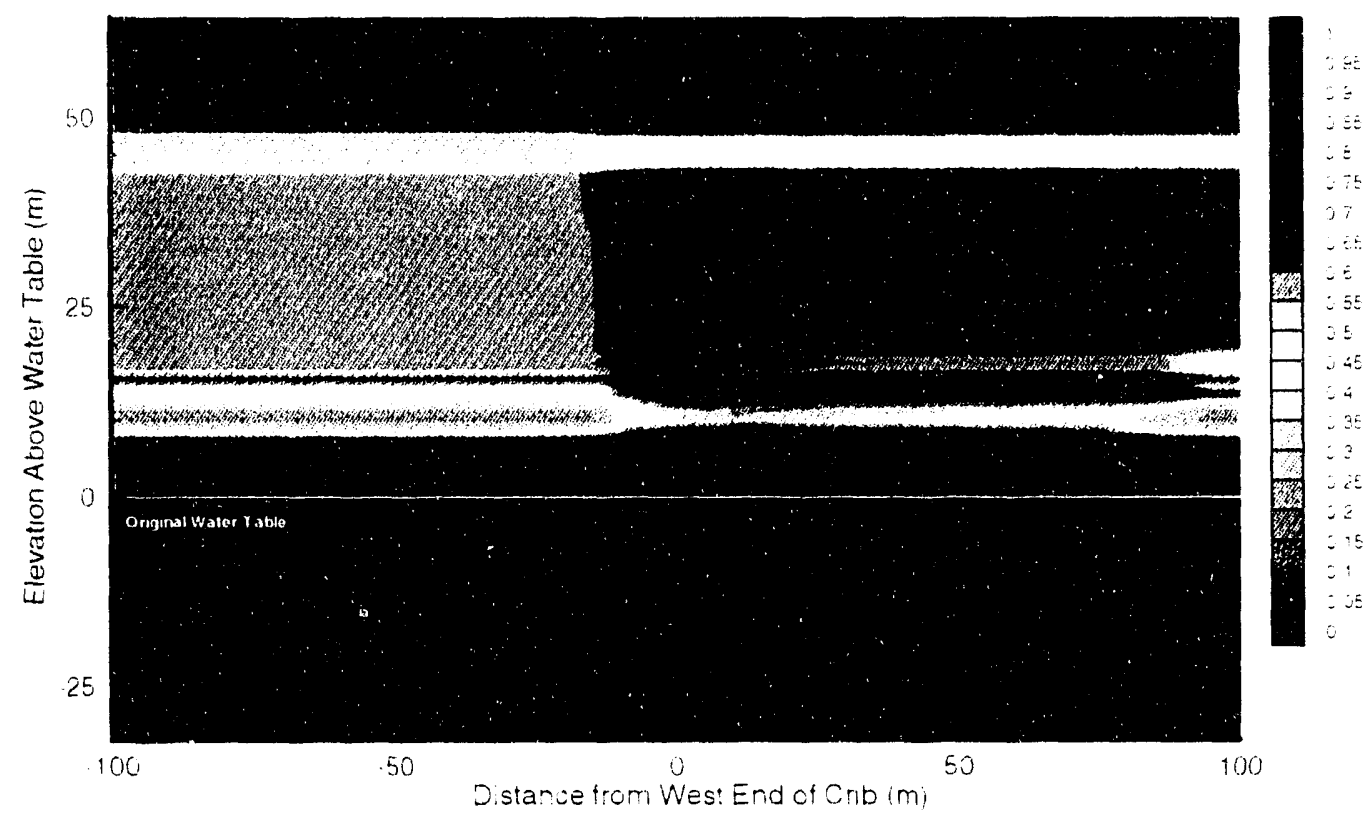

$99 / 100$ 
Figure 52. Simulation of 216-U-17 Crib-Uniform Line Source with Gross Actual Discharge - Relative Saturation on June 30, 1989

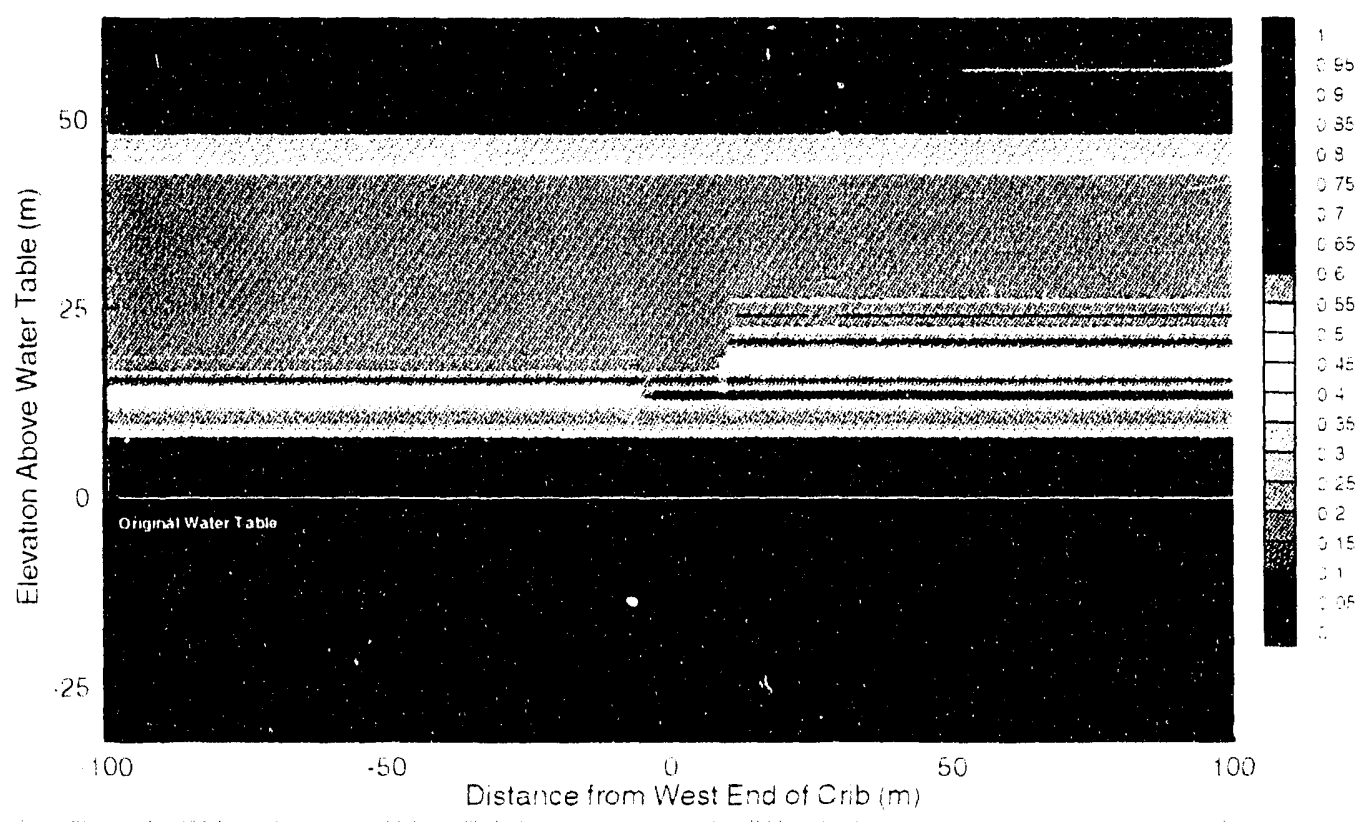

Figure 53. Simulation of 216-U. 17 Crib - Uniform Line Source with Gross Actual Discharge - Relative Saturation on June 30, 1995

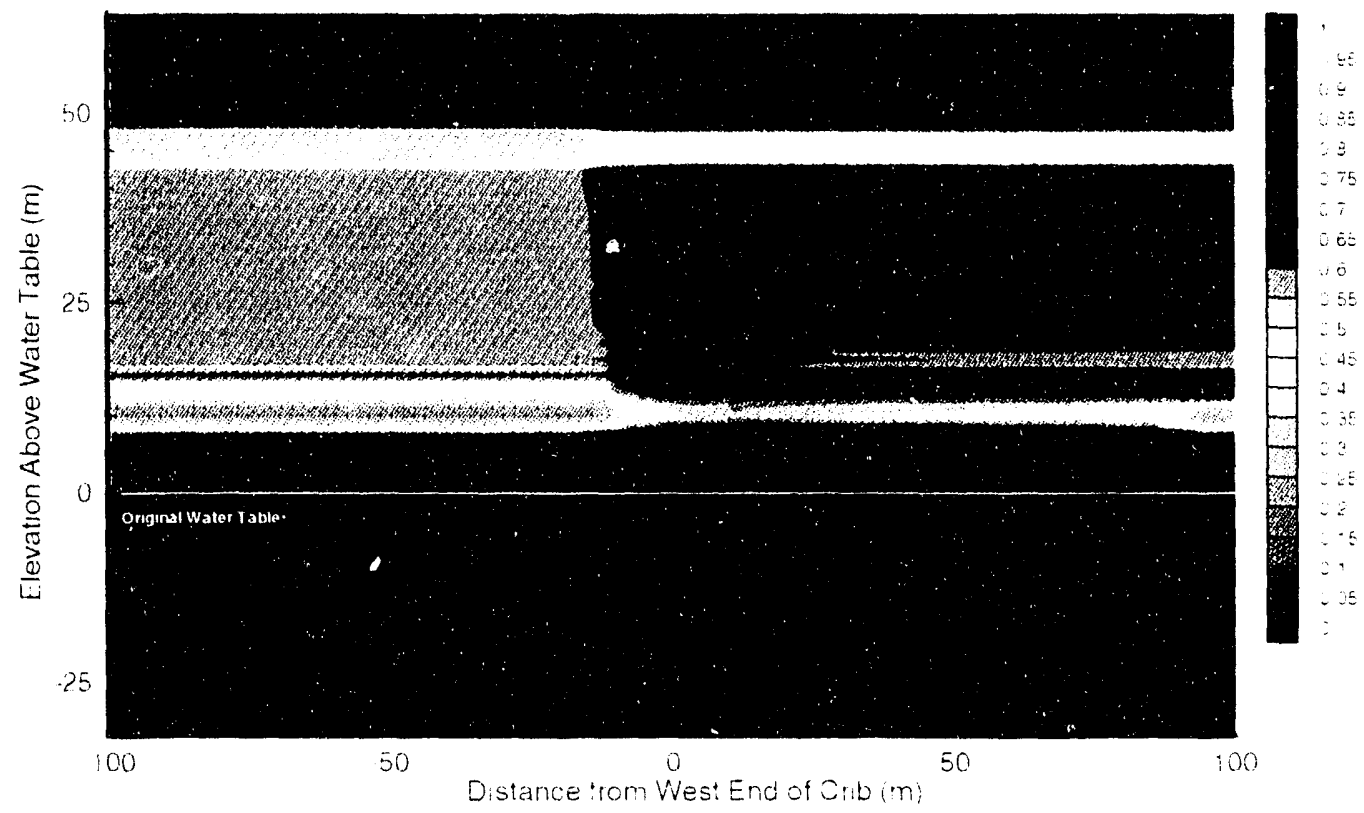

$101 / 102$ 
Table 13. Nonuniform Discharge Distribution.

\begin{tabular}{|c|c|c|}
\hline $\begin{array}{c}\text { Cumulative } \\
\text { discharge (\%) }\end{array}$ & $\begin{array}{c}\text { Cumulative } \\
\text { length (m) }\end{array}$ & $\begin{array}{c}\text { Incrementa } \\
\text { length (m) }\end{array}$ \\
\hline 20 & 1 & 1 \\
\hline 40 & 4.27 & 3.27 \\
\hline 60 & 10 & 5.73 \\
\hline 80 & 20 & 10 \\
\hline 100 & 46 & 26 \\
\hline
\end{tabular}

5.1.4.3 Simplified Generic Stratigraphy. The point source with actual discharge described above was rerun with a simplified generic stratigraphy for the 200 West Area (see Figure 33); this omits the pinched out gravel stringers (:nnes 3 and 7 ) in the Hanford formation. The purpose was to determine the importance of the details of the site-specific stratigraphy (particularly the gravel stringers) to the model. The steady-state relative saturation distribution for this case is shown in Figure 54. Relative saturation coniours on June 30,1989 are shown in Figure 55. It is immediately apparent (see Figure 55) that lateral spreading is still pronounced, but the pathways are redistributed. Comparing Figure 55 to Figures 52,50 , or 47 shows that the moisture plume is more nearly symmetric in the absence of the gravel stringer (zone 3 ) in the upper Hanford formation and, likewise, ponding because of the extensive gravel layer (zone 4) is more evenly distributed (to the east and west). The relative saturation contours on July 31,1992 and June $30, \frac{1995}{19}$ are shown in Figures 56 and 57 , respectively, which suggest more uniformity of ponding near the bottom of the Hanford formation because of contrasting hydraulic properties of the early "Palouse" soil (zone 9).

Viewing Figures 54 through 57 in sequence further suggests that while the upper layer of the Plio-Pleistocene unit (zone 10) is a conduit for ponding over the lower part of the Plio-Pleistocene unit, it might also have held perched water before construction of the 216-U-17 Crib.

Transport of conservative species in terms of relative concentration was also simulated for this case. Breakthrough curves comparable to those in Figure 49 are shown in Figure 58. From Figure 58 it can be seen that arrivals of peak relative concentration at elevations beneath the west end of the crib are virtually unaltered, which is consistent with the interpretation above for the relative saturation contours, i.e., barriers to vertical migration are present in the 200 West Area stratigraphy, and presence of additional gravel stringers in the Hanford formation serves to redistribute lateral migration.

5.1.4.4 Recharge Rate. The rate of net infiltration of precipitation is generally assumed from a range of values. For the previous model of vadose zone flow at the 216-U-17 Crib site (WHC 1950a), a time-averaged value of $5 \mathrm{~cm} / \mathrm{yr}(\mathrm{q}=5 \mathrm{~cm} / \mathrm{yr})$ was used. For all of the present simulations reported to this point, a value of $q=10 \mathrm{~cm} / \mathrm{yr}$ has been used. The higher recharge 
WHC-EP-0664

This page intentionally left blank. 
Figure 54. Simulation of 216-U-17 Crib Steady-State Moisture Distribution.

Generic Stratigraphy

Assumed Recharge Rate $=10 \mathrm{~cm} / \mathrm{yr}$

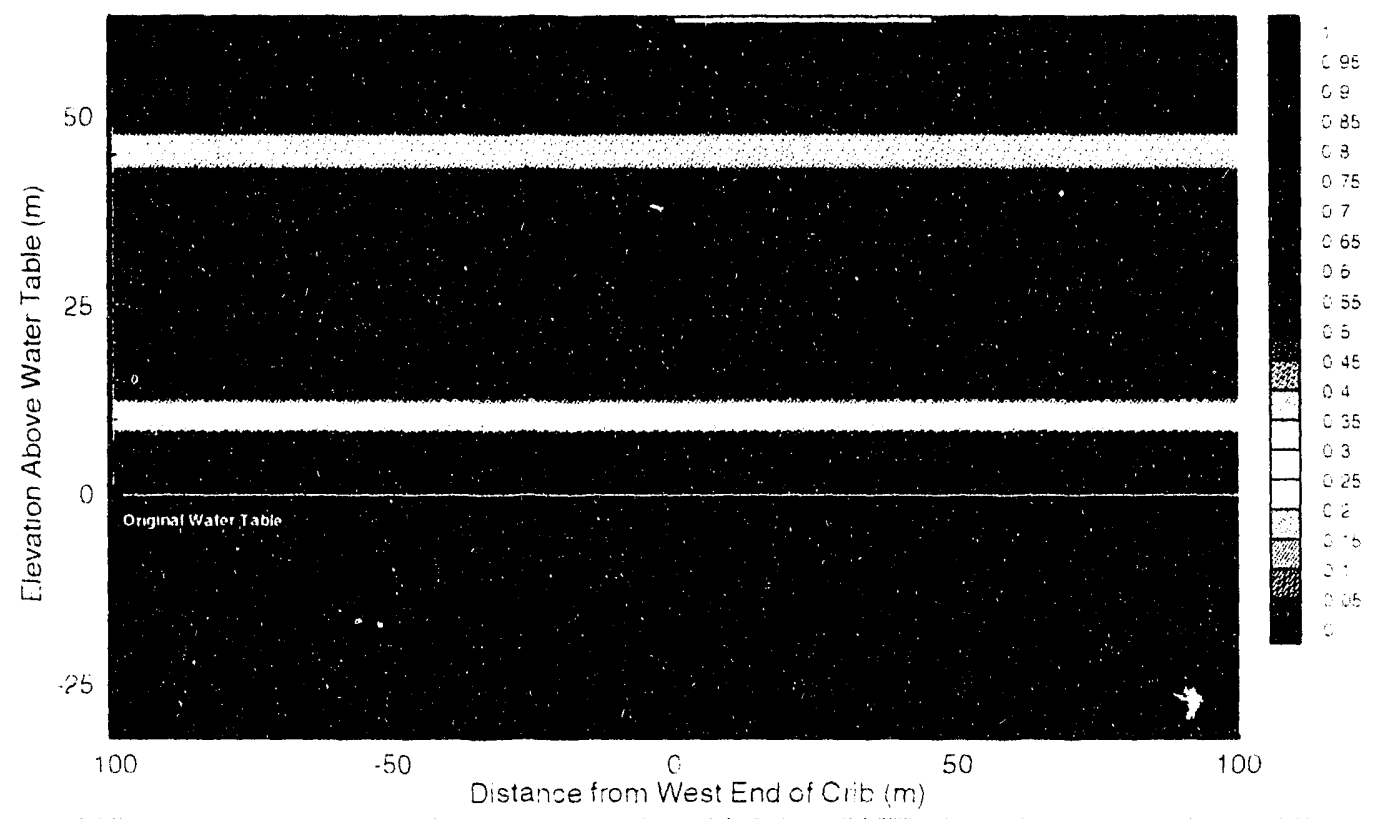

Figure 55. Simulation of 216-U-17 Crib - Point Source

Generic Stratigraphy - Relative Saturation

on June 30, 1989.

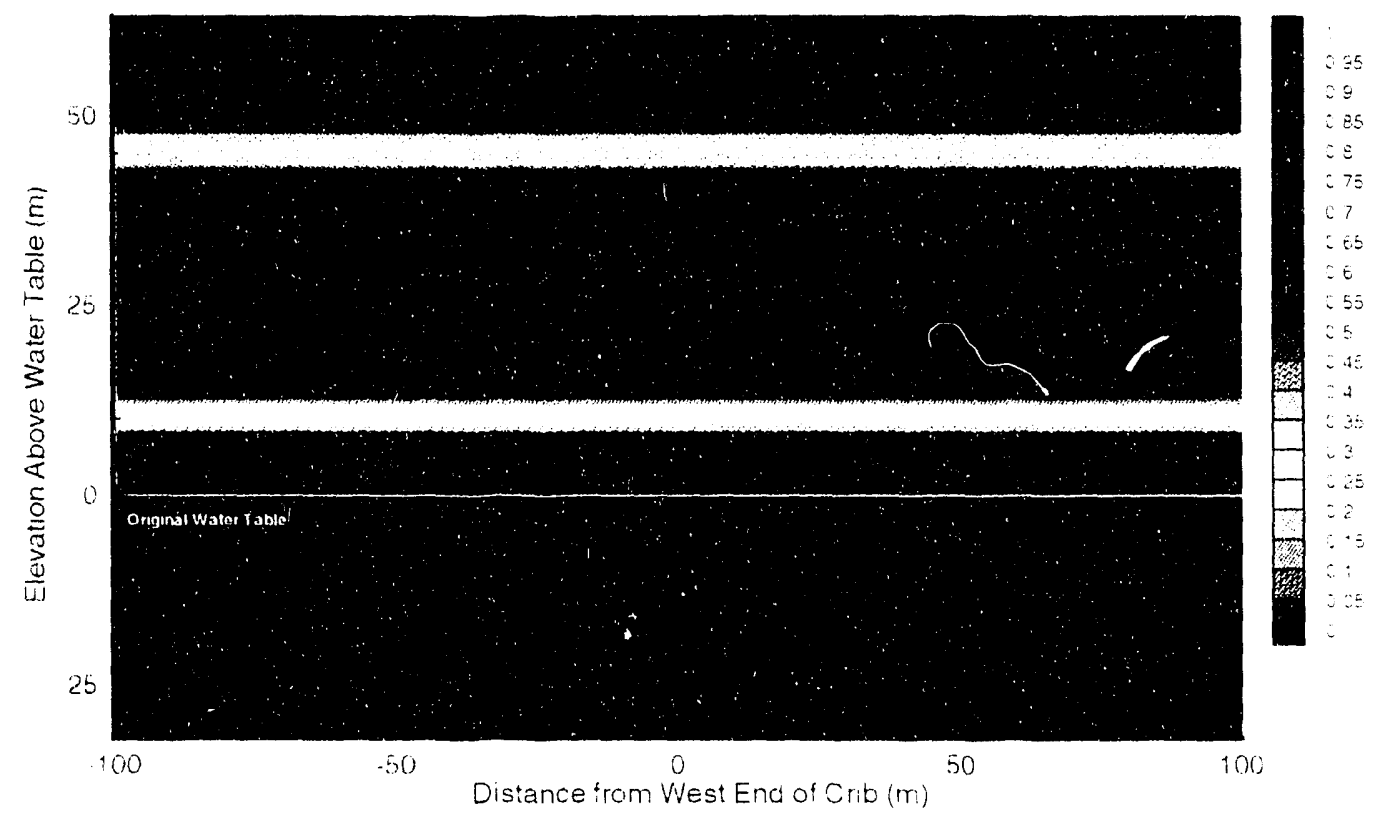

$105 / 106$ 
Figure 56. Simulation of 216-U-17 Crib-Pont Source .

Reneric Stratigrapily - Relative Saturation

on July 31, 1992

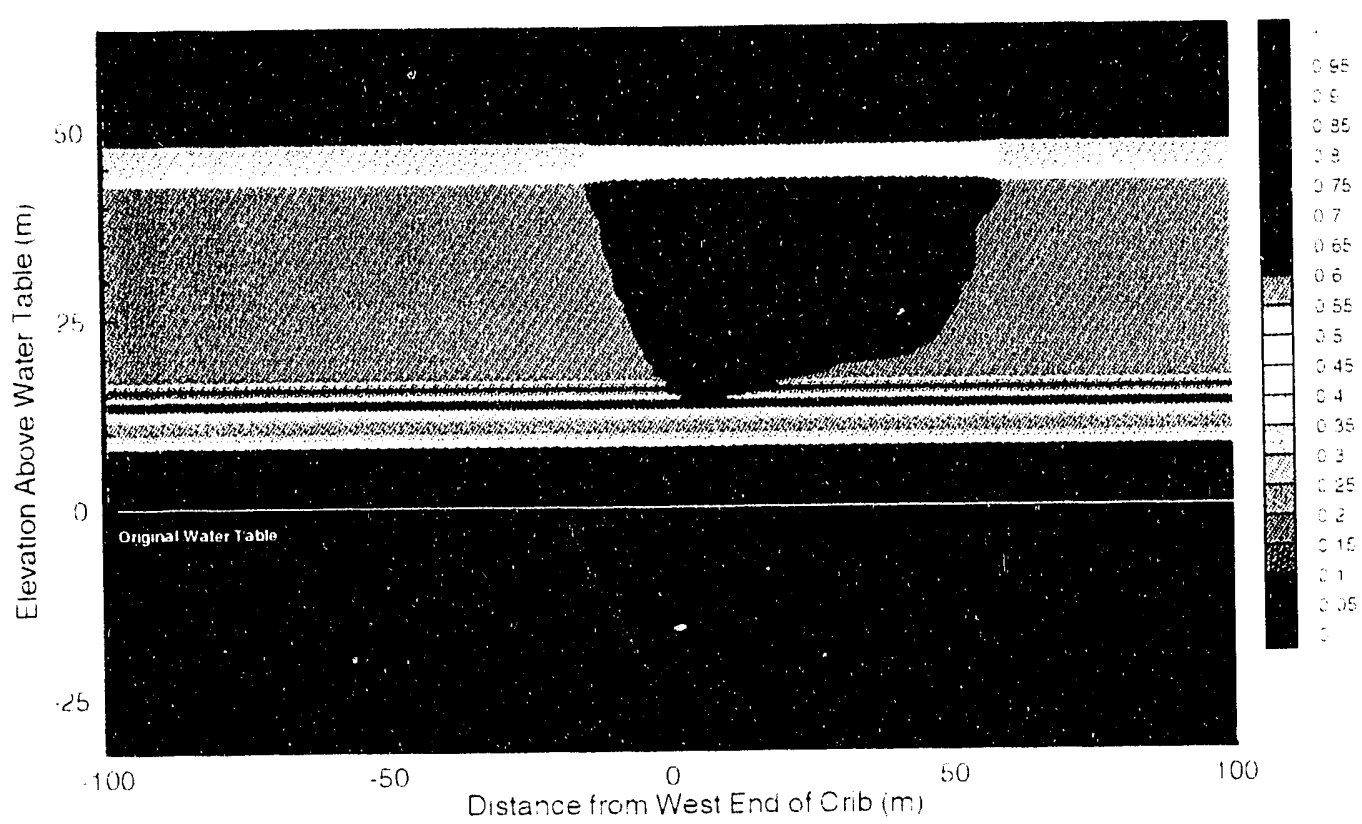

Figure 57 Simulation of 216-U-17 Crib-Point Source Generic Stratigraphy - Relative Saturation

on June 30, 1995

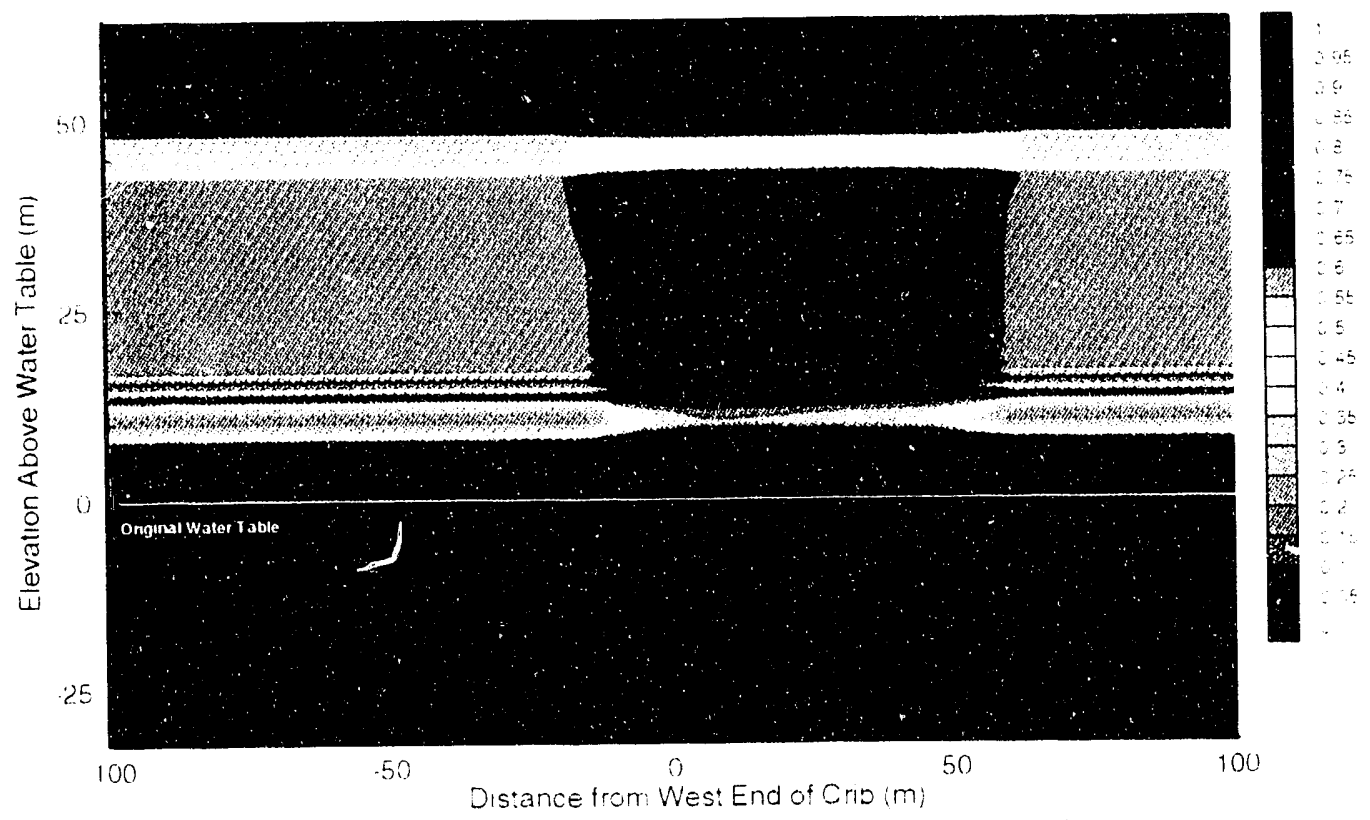

$107 / 108$ 
Figure 58. Simulation of 216-U-17 Crib - Point Source Generic Stratigraphy - Time History of Relative Concentration.

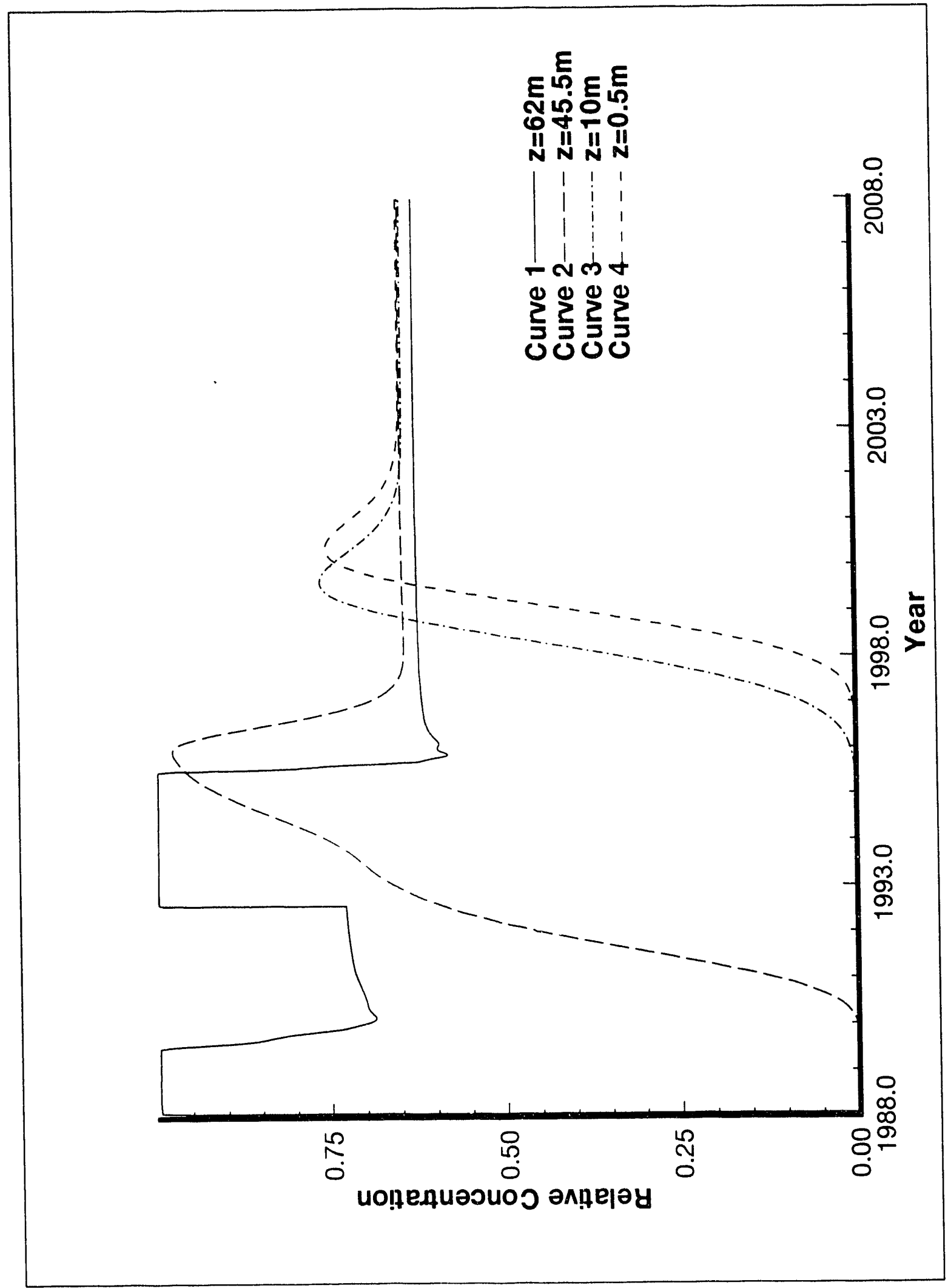


rate facilitates simulation of the initial steady state, but does not appreciably affect the simulated relative saturations. In terms of the hydraulic characteristics used for the present model, both 5 and $10 \mathrm{~cm} / \mathrm{yr}$ produce soil moisture tensions of similar magnitudes at relatively low volumetric moisture content. Modest reductions in differences between initial soil moisture tension for adjacent zones (such as zones 2 and 3 ) can greatly reduce computational effort needed to simulate a conceptually simple steadystate flow field. However, to assess the importance of the assumed value of recharge rate, the same simulation case from Section 5.1.4.2.1 (ful1 stratigraphy, point source, gross actual discharges) was rerun with a recharge rate of $q=5 \mathrm{~cm} / \mathrm{yr}$.

For this case the initial steady-state flow field was resimulated with the lower recharge rate of $q=5 \mathrm{~cm} / \mathrm{yr}$. The steady-state relative saturation distribution assumed to be representative of conditions before start of crib operation is shown in Figure 59. Comparison to the steady state with $q=$ $10 \mathrm{~cm} / \mathrm{yr}$ in Figure 35 shows no appreciable difference, except that in the latter case the crib backfill (zone 1) is superimposed on the relative saturation distribution while not in the former.

Additional plots of relative saturation contours are not shown for this case because they are nearly similar to previous cases. Relative concentration breakthrough curves for this case are shown in Figure 60, and suggest arrival times similar to previous results (e.g., Figure 58). As discussed previously, Figure 61 suggests that significant relative concentrations could persist well beyond site closure in the absence of substantial driving forces from crib discharges.

After planned termination of crib operation in June 1995, the only driving forces are from dissipation of ponded/mounded water and recharge caused by infiltration of precipitation (around and presumably through a degrading polyvinyl chloride [PVC] membrane overlying the gravel backfi11). Time history of wetting and drying of the soil at elevations beneath the crib (Figure 62) indicate that dissipation of discharged fluid could take as much as 50 years. This is most likely an upper bound because of the restriction on north-south migration inherent in the two-dimensional model. An important point to be considered is that once crib discharges have dissipated, the only driving force remaining is from recharge, which may be as 1 ittle as $0.1 \mathrm{~mm} / \mathrm{yr}$.

5.1.4.5 Best-Estimate Simulation. This section describes what is believed to be the best estimate of conditions that prevail at the $216-U-17$ Crib. The base case simulations and variations described previously demonstrate that the stratigraphy of the 200 West Area and, in particular, the site-specific stratigraphy at the 216-U-17 Crib site is a substantial barrier to vertical flow, even for the isotropic hydraulic conductivity case. The two-dimensional unit thickness domain enhanced lateral spreading, while the "leaky" boundary conditions are preferred over the often-used zero flux conditions that present an unnatural barrier to lateral flow in this case. A point source was shown to be an adequate representation of the source of discharges from the perforated pipe to the crib backfill. The simplified or generic 200 West Area stratigraphy and the site-specific stratigraphy at the $216-\mathrm{U}-17 \mathrm{Crib}$ were found to be equivalent in terms of arrival time of peak concentration at the bottom of the Plio-Pleistocene unit; however, gravel stringers in the Hanford formation were found to be important redistributors of lateral flow beneath the crib. The average rate of soil moisture recharge because of net 
Figure 59. Simulation of 216-U-17 Crib - Assumed

$5 \mathrm{~cm} / \mathrm{yr}$ Recharge Rate - Relative Saturation

on January 31, 1988.

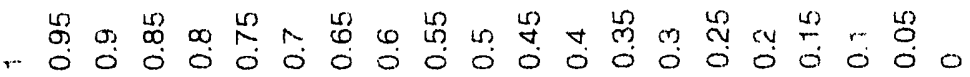

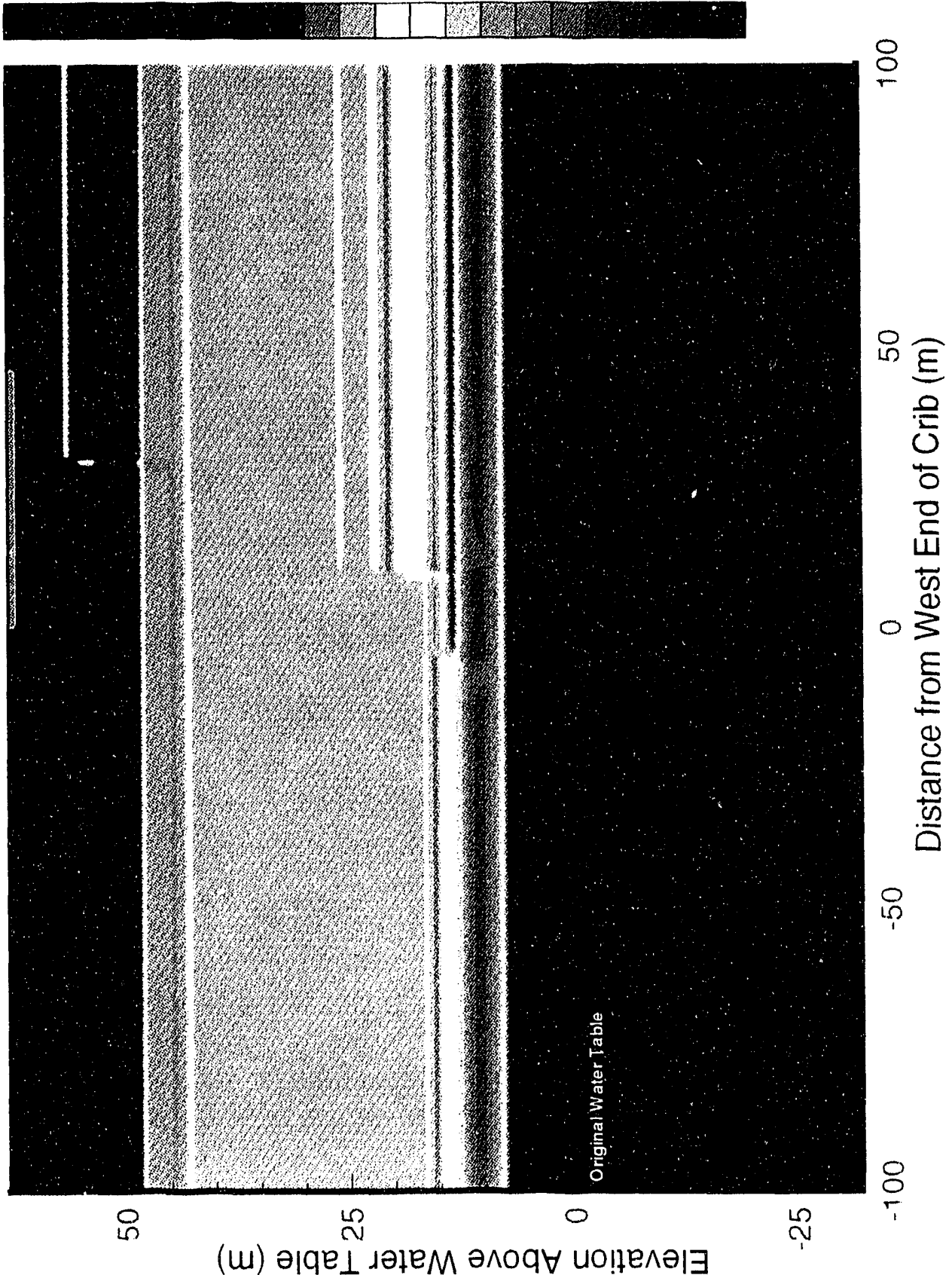

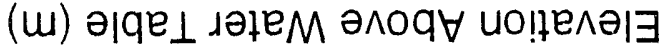


Figure 60. Simulation of 216-U-17 Crib - Assumed

$5 \mathrm{~cm} / \mathrm{yr}$ Recharge Rate - 20-Year Time History of Relative Concentration.

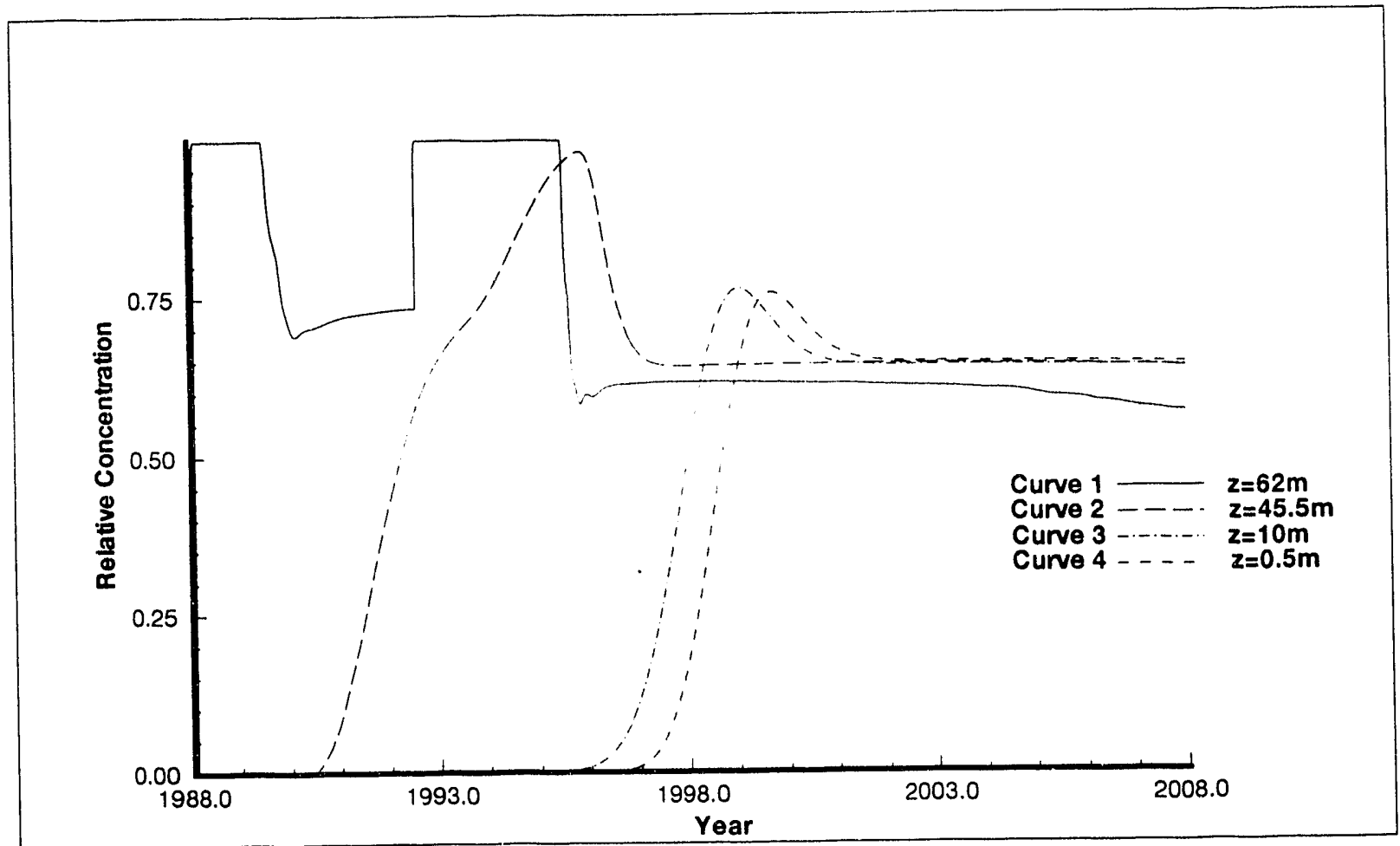

Figure 61. Simulation of 216-U-17 Crib - Assumed

$5 \mathrm{~cm} / \mathrm{yr}$ Recharge Rate - 50-Year Time History of Relative Concentration.

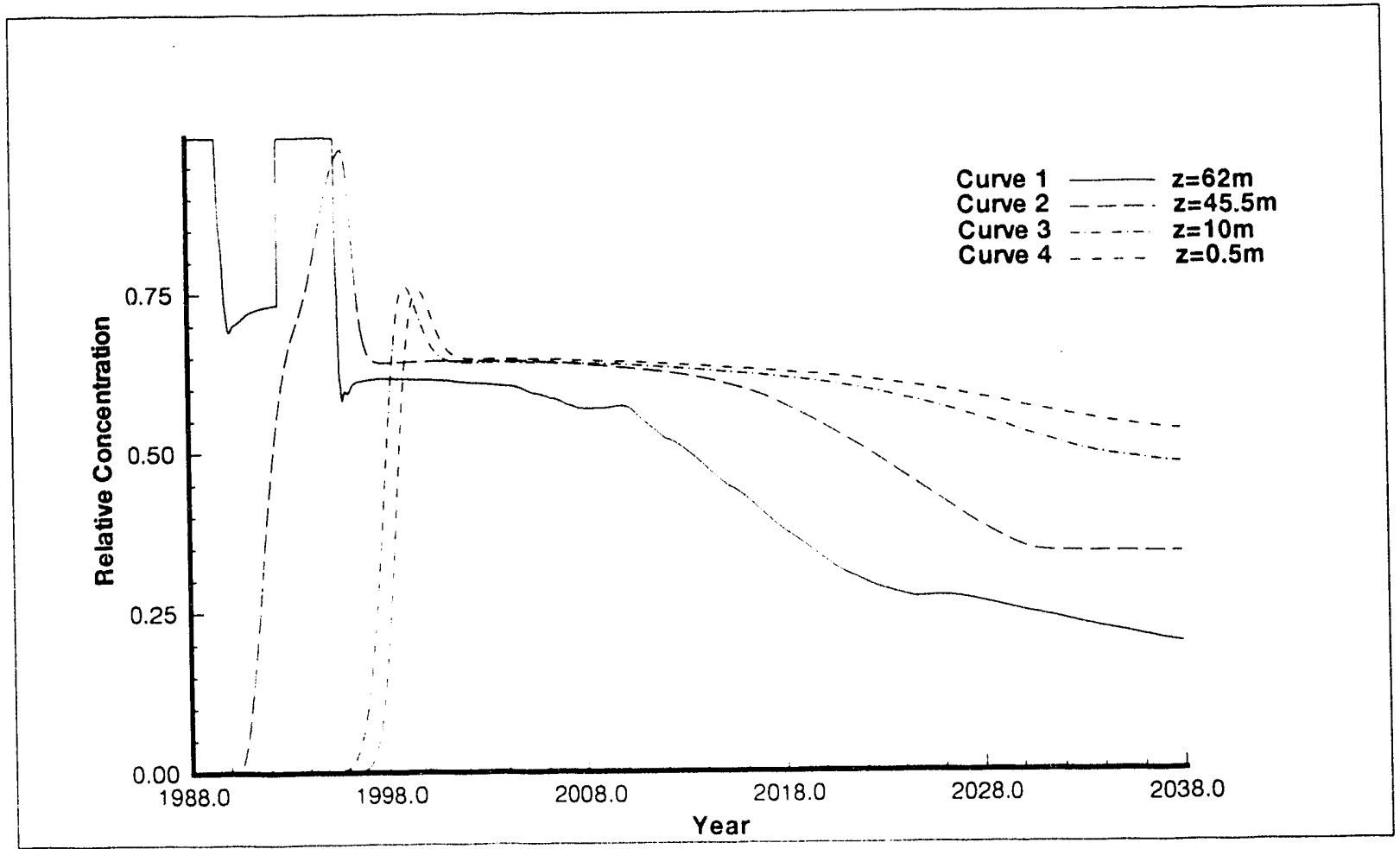


Figure 62. Simulation of 216-U-17 Crib-Assumed $5 \mathrm{~cm} / \mathrm{yr}$ Recharge Rate - Time History of Relative Saturation.

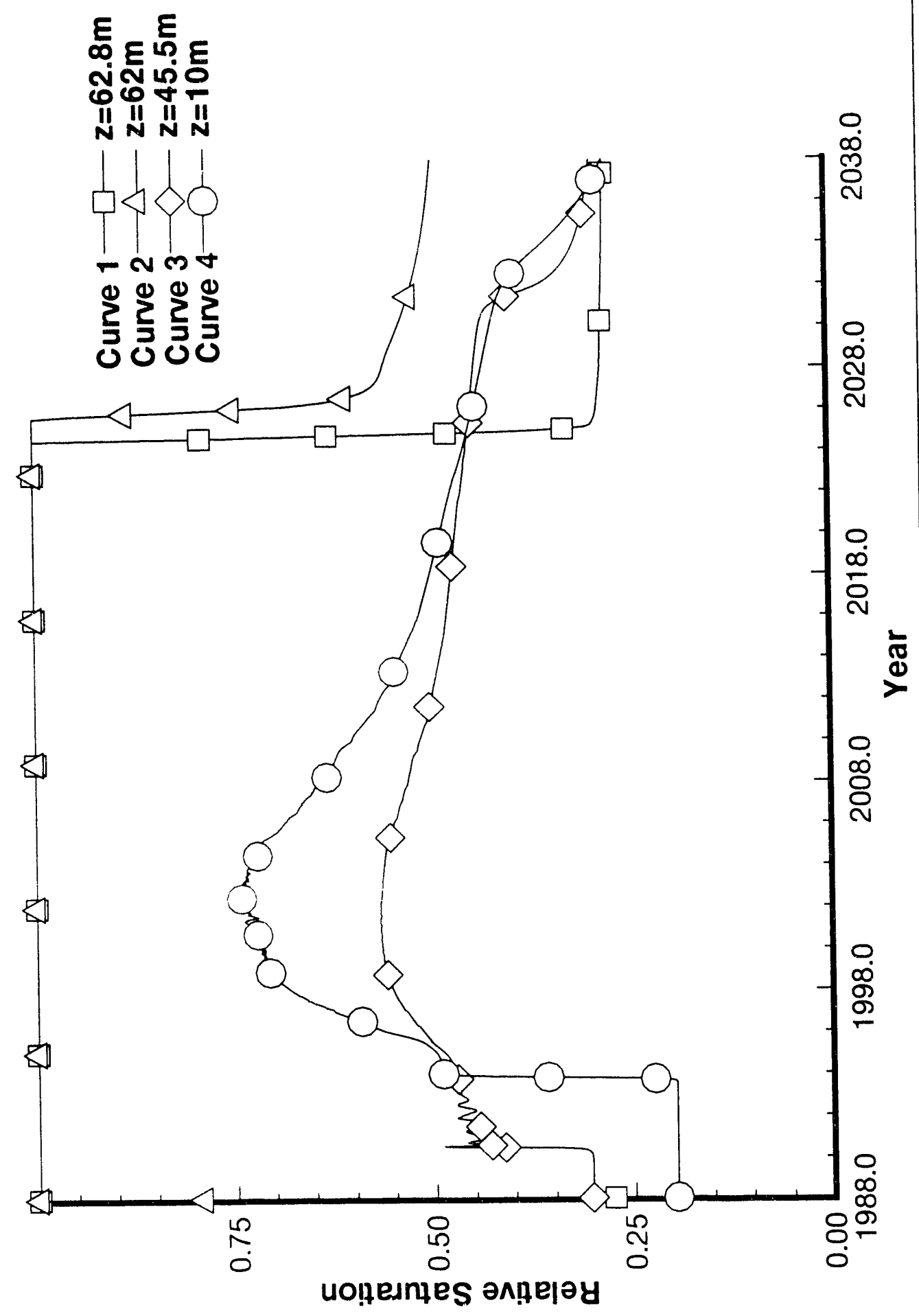


infiltration of precipitation was shown to not substantially affect arrival time of peak concentration under the base case assumptions; thus, it is not considered to be an important parameter during a short-term simulation of crib operation. However, after discharges cease and discharged liquid has dissipated, the recharge rate becomes the principal driving force.

The best-estimate simulation case uses tia physical properties from Section 5.1.2, which are considered to be the best estimates presently available, the boundary conditions summarized in Figure 34 (including the "leaky" boundary conditions), and a point source for reasons described in previous sections. Additional details are added to this case incrementaily (as opposed to analyzed individually as was done with the base case).

5.1.4.5.1 Monthly Actual Discharges. The base case model variation described in Section 5.1.4.4 (with site-specific stratigraphy, $\Delta y=1 \mathrm{~m}$, and $q=5 \mathrm{~cm} / \mathrm{yr}$ ) is the starting point from which the best-estimate case is constructed. In Section 5.1.4.2.1 it was noted that the point source with actual/planned discharges from Table 12 obtained similar results for the case of a short line source $(20 \mathrm{~m}$ in length) with a constant discharge rate of about $1 \mathrm{gal} / \mathrm{min}$. The actual discharges are preferable for assessing impact to groundwater in terms of contaminant concentration, and also for maintaining contaminant mass balance.

The first step in construction of the best-estimate case is incorporation of the monthly actual discharge volumes from Table 4 for the period from February 1988 through June 1989. Further discharges through June 1995 are estimated from Table 3 . Those estimated volumes are bracketed by entries in the lower section of Table 14. Concentrations of uranium in the effluent (see Table 14) are applied at the point source for simulating concentrations of transported uranium. The time history of the boundary concentration of uranium (propagated to a depth of $0.4 \mathrm{~m}$ below the point source node) is shown in Figure 63.

Simulated relative saturation on June 30, 1995 for this case is shown in Figure 64. The immediate conclusion to be drawn from comparison of Figure 64 to Figure 48 is that, even though the series of monthly pulses used to drive this simulation is a more accurate representation of the actual practice of discharges of slugs to the crib from the $\mathrm{UO}_{3}$ Plant, the simulated flow field is virtually the same for both cases. The value of using accurate actual discharges is in conserving balance of uranium mass represented by simulated uranium concentrations. Uranium breakthrough curves (assuming no decay and no retardation) are shown in Figure 65.

5.1.4.5.2 Retardation and Lateral Spreading. It has been clearly established that, even though the effective hydraulic conductivity has been assumed to be isotropic, contrast between layers in the stratigraphy can cause pronounced lateral flow and transport. To minimize compounding with the twodimensional model, the unit thickness is changed back to a $3-m$ thickness $(\Delta y=3 \mathrm{~m})$ as in Section 5.1.4.1. Although this difference did not produce dramatic differences in results (see Section 5.1.4.1.1), the 3-m thickness more accurately represents both the width of the trench floor and the effective volume of backfill. This is consistent with the thrust of the bestestimate case construction. 
Figure 63. Simulation of 216-U-17 Crib - Time History of Uranium Concentration Under the Point Source.

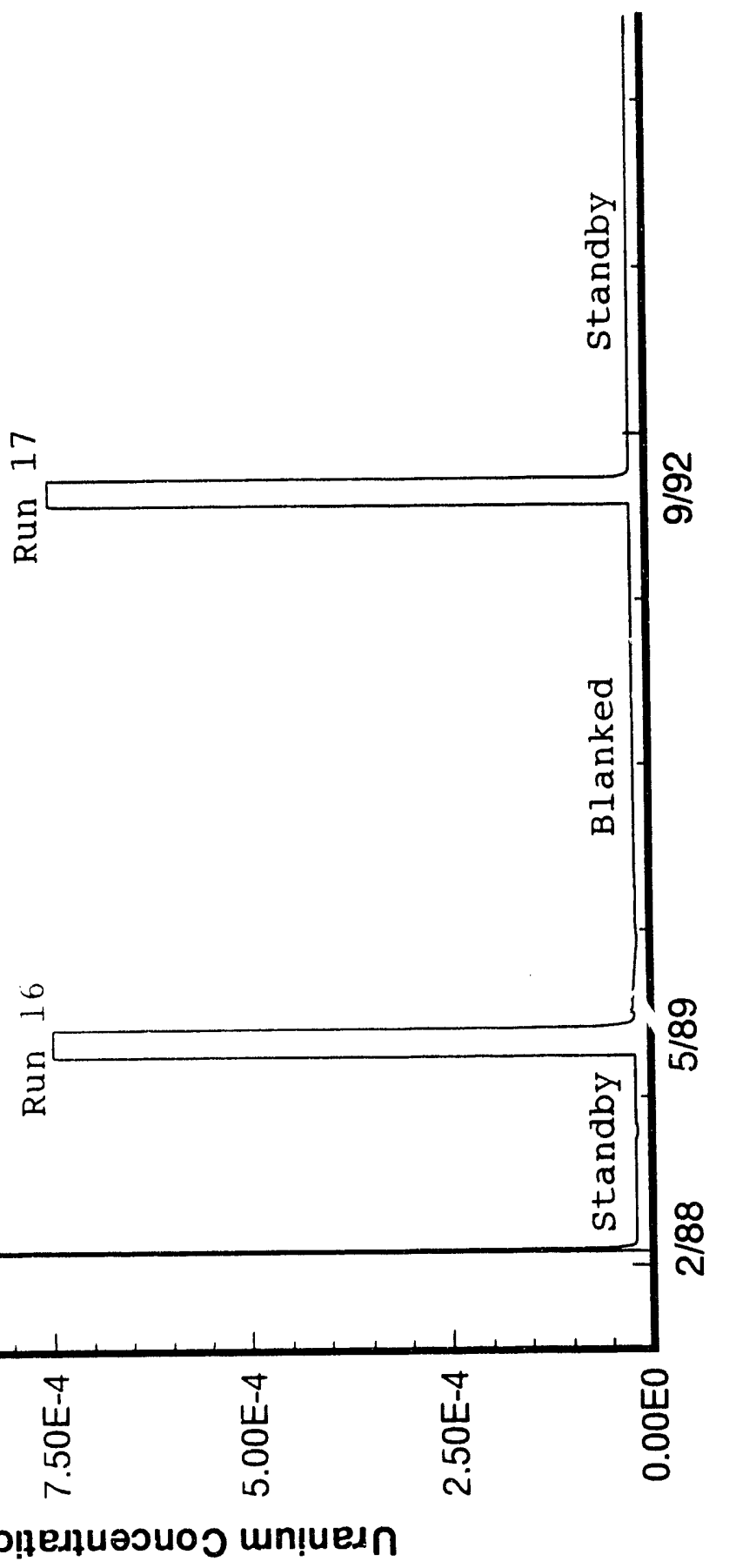


Figure 64. Simulation of 216-U-17 Crib - Point Source with Monthly Actual Discharges - Relative Saturation Contours on June 30, 1995.

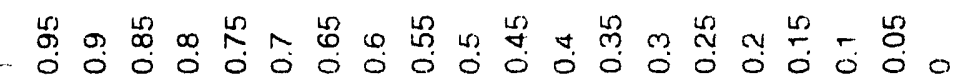

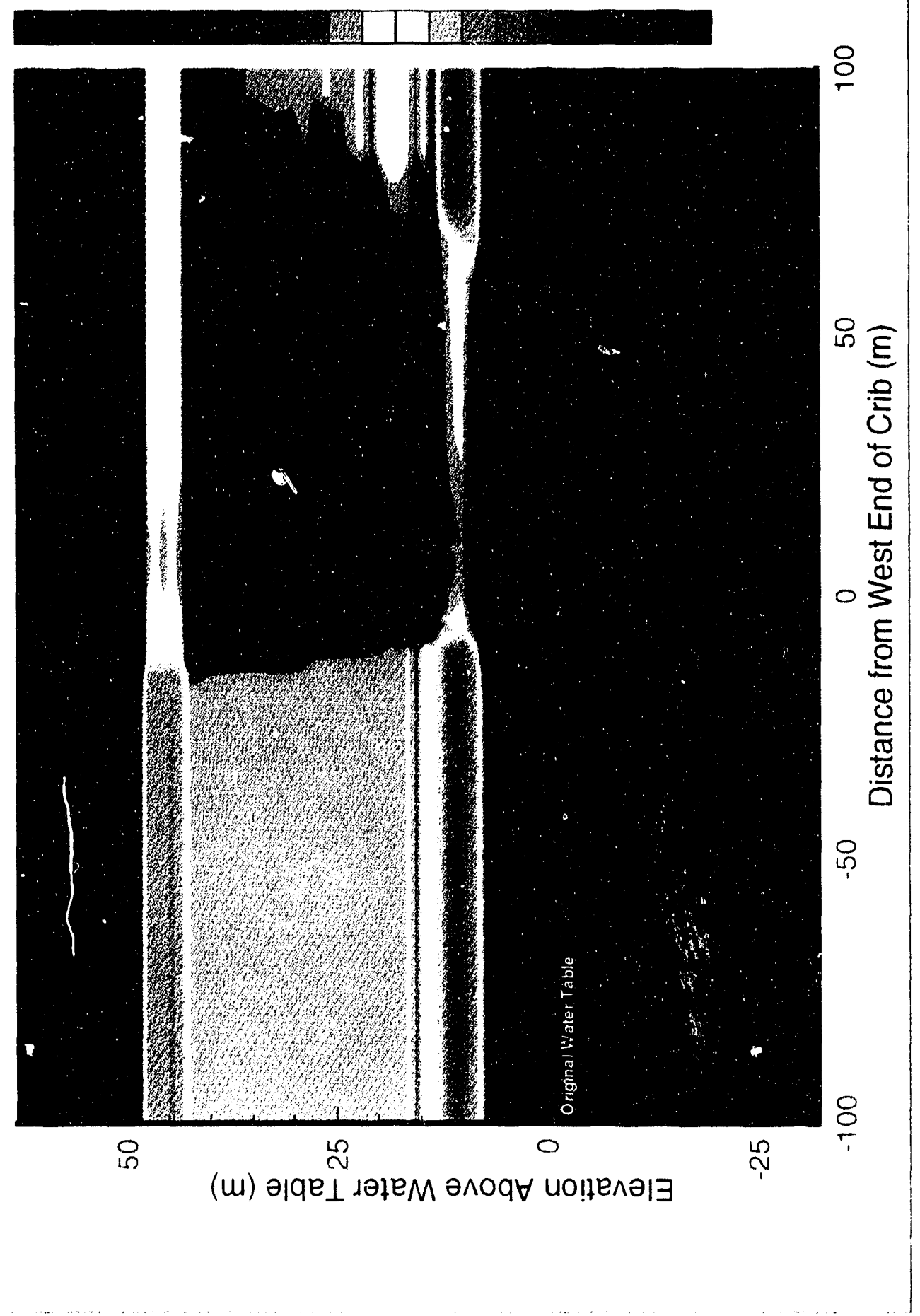


Figure 65. Simulation of 216-U-17 Crib - Puint Source with Monthly Actual Discharges - Time History of Uranium Concentration.

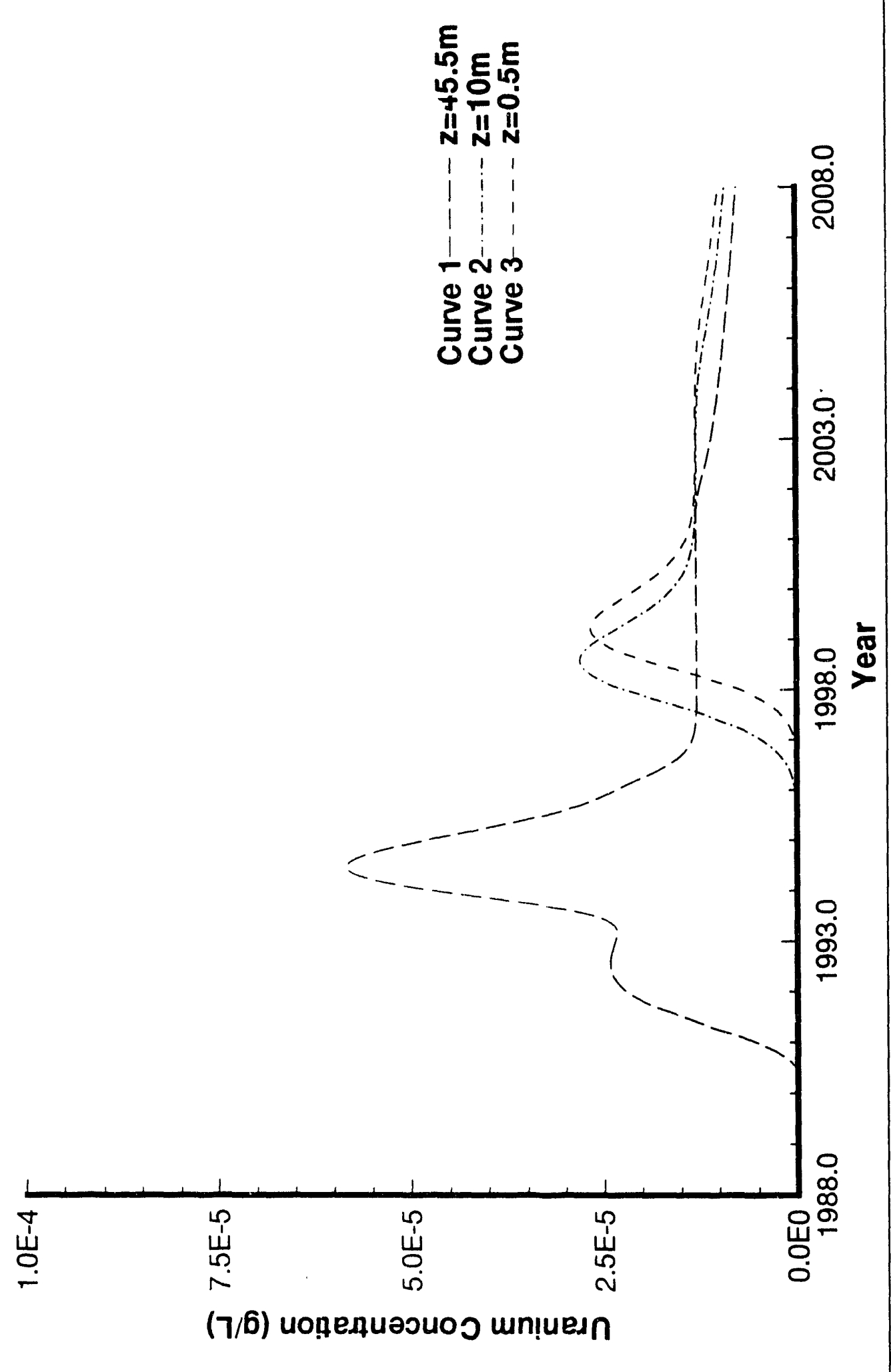


Table 14. Summary of Discharge Volumes and Uranium Concentration from $\mathrm{UO}_{3} \mathrm{Pl}$ ant.

\begin{tabular}{|c|c|c|c|c|}
\hline Time period & $\begin{array}{c}\text { Volume discharged } \\
(\mathrm{gal})\end{array}$ & $\begin{array}{c}\text { Plant } \\
\text { status }\end{array}$ & $\begin{array}{c}\text { Concentrations } \\
\text { (total } \\
\text { uranium) }\end{array}$ & $\begin{array}{c}\text { Technetium } \\
(\mu \mathrm{Ci} / \mathrm{L})\end{array}$ \\
\hline $1 / 31 / 88-2 / 1 / 88$ & $\mathrm{nil}$ & Standby & $0.00002 \mathrm{~g} / \mathrm{L}$ & 0.0009 \\
\hline $2 / 1 / 88-2 / 6 / 88$ & 53,110 & Run 15 & $0.0012 \mathrm{~g} / \mathrm{L}$ & 0.008 \\
\hline $2 / 6 / 88-4 / 20 / 89$ & 202,494 & Standby & $0.00002 \mathrm{~g} / \mathrm{L}$ & 0.0009 \\
\hline $4 / 20 / 89-5 / 17 / 89$ & 286,344 & Run 16 & $0.00075 \mathrm{~g} / \mathrm{L}$ & 0.0013 \\
\hline $5 / 17 / 89-7 / 89$ & 15,252 & Standby & $0.00002 \mathrm{~g} / \mathrm{L}$ & 0.0009 \\
\hline $7 / 89-5 / 21 / 92$ & 0 & Blanked & -- & - \\
\hline $5 / 21 / 92-8 / 15 / 92$ & 300,000 & Standby & $0.00002 \mathrm{~g} / \mathrm{L}$ & 0.0009 \\
\hline $8 / 15 / 92-9 / 30 / 92$ & 300,000 to 500,000 & Run 17 & $0.00075 \mathrm{~g} / \mathrm{L}$ & 0.0013 \\
\hline $9 / 30 / 92-6 / 30 / 95$ & 500,000 to $1,200,000$ & Standby & $0.00002 \mathrm{~g} / \mathrm{L}$ & 0.0009 \\
\hline
\end{tabular}

To this point lateral spreading in the vadose zone has been emphasized. However, the hydraulic gradients in the unconfined aquifer are important in the dissipation of mounded water in the Plio-Pleistocene unit and transport (dilution) of solute away from the crib site. For all cases reported here thus far and for the previous flow model (WHC 1990a), the gradient in the unconfined aquifer was assumed to be on the order of $10^{-4} \mathrm{~m} / \mathrm{m}$. From the water table elevations shown in Figure 12, the hydraulic gradient in the unconfined aquifer is estimated to be about $0.003 \mathrm{~m} / \mathrm{m}$ under the crib site before disturbance from discharges to the $216-\mathrm{U}-17 \mathrm{Crib}$. This gradient of about $4.8 \mathrm{~m} / \mathrm{km}$ ( $15 \mathrm{ft} / \mathrm{mi}$ ) is due to mounding to the west from prior discharges to ponds (216-U-10) and other cribs (particularly 216-U-14 and 216-U-16).

Following cessation of fluid discharges to the 216-U-17 Crib, dissipation of the effluent (both laterally and vertically) in the soil column will gradually evolve to near steady conditions disturbed only by variations in recharge (or unforeseen conditions). Retardation, because of sorption $\left(K_{d}>0\right)$ of solute species, is important in determining the extent to which dissipation of discharged fluid will contaminate the host soil column (both laterally and vertically). All simulation cases so far have involved only transport without consideration of sorption or radioactive decay. Radioactive decay is relatively unimportant with respect to the time periods simulated in cases considered thus far. However, uranium is expected to be retarded because of sorption by the soil at the 216-U-17 Crib site. The value of the effective sorption coefficient $\left(K_{d}\right)$ used for modeling is not known precisely, but for the best-estimate case, a value of $k_{d}=1 \mathrm{~cm}^{3} / g$ is assigned for 
uranium based on effluent characteristics and uranium behavior in Hanford formation soils (Ames and Serne 1991).

The three refinements described in this section (thickness, gradient, sorption) were added incrementally to the best-estimate case. The cumulative effect of resetting $\Delta y=3 \mathrm{~m}$, estimating the hydraulic gradient in the aquifer to be 0.003 , and assuming a $K_{d}=1 \mathrm{~cm}^{3} / \mathrm{g}$ for uranium is shown in Figures 66 through 69. Figure 66 shows time history of relative saturation for several elevations under the point source, and suggests that ponding/mounding is mitigated by the soil column after about 50 years. This is not substantially different from results shown in Section 5.1.4.4 (see Figure 62). Uranium breakthrough curves are shown in Figure 67 . These results indicate that a peak uranium concentration of about $0.1 \mathrm{mg} / \mathrm{L}(100 \mathrm{ppb})$ will travel downward to a depth of about $20 \mathrm{~m}$ beneath the crib (zone 4; Hanford formation) by about the year 2000. Uranium concentration of about $0.01 \mathrm{mg} / \mathrm{L}(10 \mathrm{ppb})$ will not occur at the bottom of the Plio-Pleistocene unit for at least 50 years (see Figure 67). Figures 68 and 69 show the uranium plume for this case after 50 (January 31,2038 ) and 100 jears (January 31,2088 ), respectively.

5.1.4.5.3 Revised Actual Discharges and Recharge Rate. At the beginning of this numerical modeling exercise, the only available data on actual discharges to the 216-U-17 Crib were that summarized in Table 4 for the time period from February 1988 to June 1989. Beyond that time, only estimates were available for the planned run 17 from the $\mathrm{UO}_{3}$ Plant (August to September 1992) and following standby until June 1995. Late in the model development, data on actual discharges for standby operation from May 1992 to April 1993 became available along with data for the first discharges from run 17 . These discharge updates are reflected in Table 15, and were added to the numerical mode1. The only appreciable difference between Table 15 and the comparable portion of Table 14 is the start time of run 17. The approximately 7-month later start time for actual discharges from run 17 translates into a slightly later arrival time for peak uranium concentration at the top of the upper Ringold Formation. With this late adjustment for actual discharges, the simulated uranium plume and travel time to the unconfined aquifer are not distinct from those implied by Figures 67 through 69 .

Table 15. Revised Discharges for Run 17.

\begin{tabular}{|c|c|c|c|}
\hline Time period & $\begin{array}{c}\text { Volume discharged } \\
\text { (gal) }\end{array}$ & $\begin{array}{c}\text { Plant } \\
\text { status }\end{array}$ & $\begin{array}{c}\text { Concentrations } \\
\text { (total uranium) }\end{array}$ \\
\hline $5 / 21 / 92-12 / 31 / 92$ & 241,566 & Standby & $0.000027 \mathrm{~g} / \mathrm{L}$ \\
\hline $12 / 31 / 92-4 / 5 / 93$ & 82,004 & Standby & $0.0002 \mathrm{~g} / \mathrm{L}$ \\
\hline $4 / 5 / 93-5 / 15 / 93$ & 300,000 to 500,000 & Run 17 & $0.00075 \mathrm{~g} / \mathrm{L}^{\mathrm{a}}$ \\
\hline $5 / 15 / 93-6 / 30 / 95$ & 500,000 to $1,200,000$ & Standby & $0.00002 \mathrm{~g} / \mathrm{L}$ \\
\hline
\end{tabular}

${ }^{a}$ So far on run 17, Apri1 5-16, 1993, uranium has averaged $0.00000422 \mathrm{~g} / \mathrm{L}$ (4.2 ppb) for $286,101 \mathrm{~L}$. 
Figure 66. Simulation of 216-U-17 Crib - Construction of

Best-Estimate Case - Full Thickness and Actual

Gradient in the Aquifer - Time History of Relative Saturation.

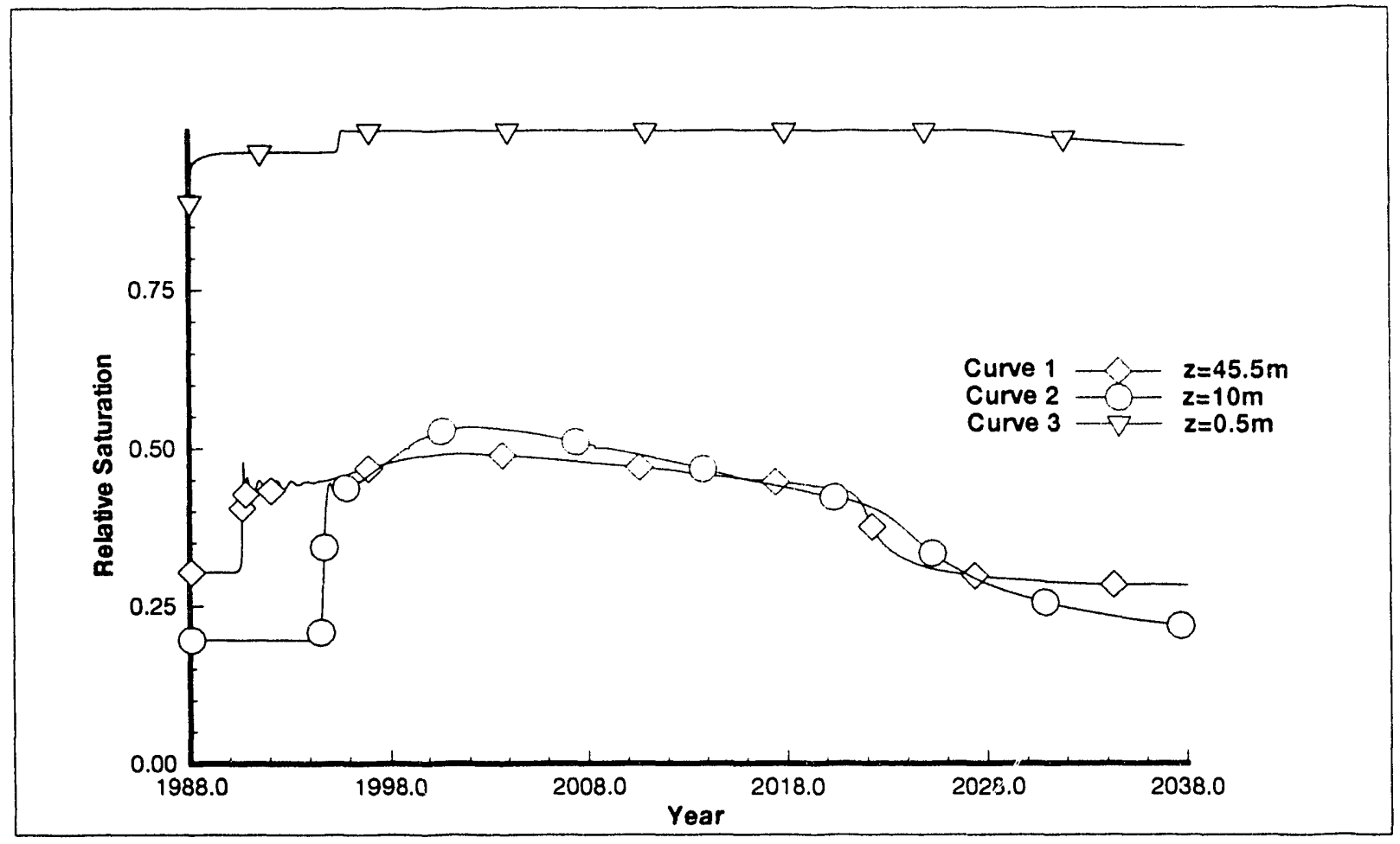

Figure 67. Simulation of 216-U-17 Crib - Construction of

Best-Estimate Case - Full Thickness and Actual

Gradient in the Aquifer - Time History of Uranium Concentration.

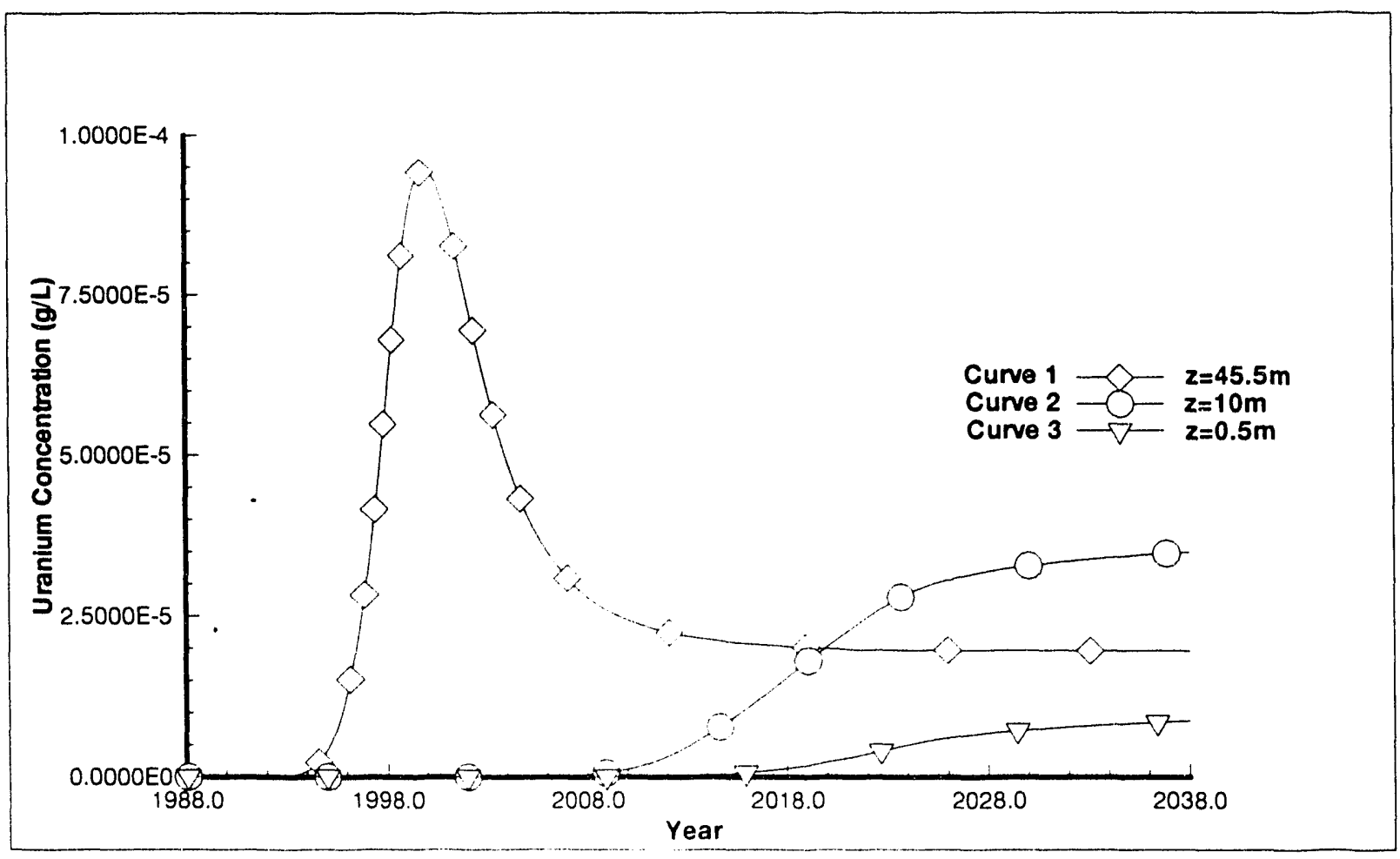


Figure 68. Simulation of 216-U-17 Crib - Construction of Best-

Estimate Case - Full Thickness and Actual Gradient in the Aquifer - Uranium Concentration Contours on January 31, 2038.

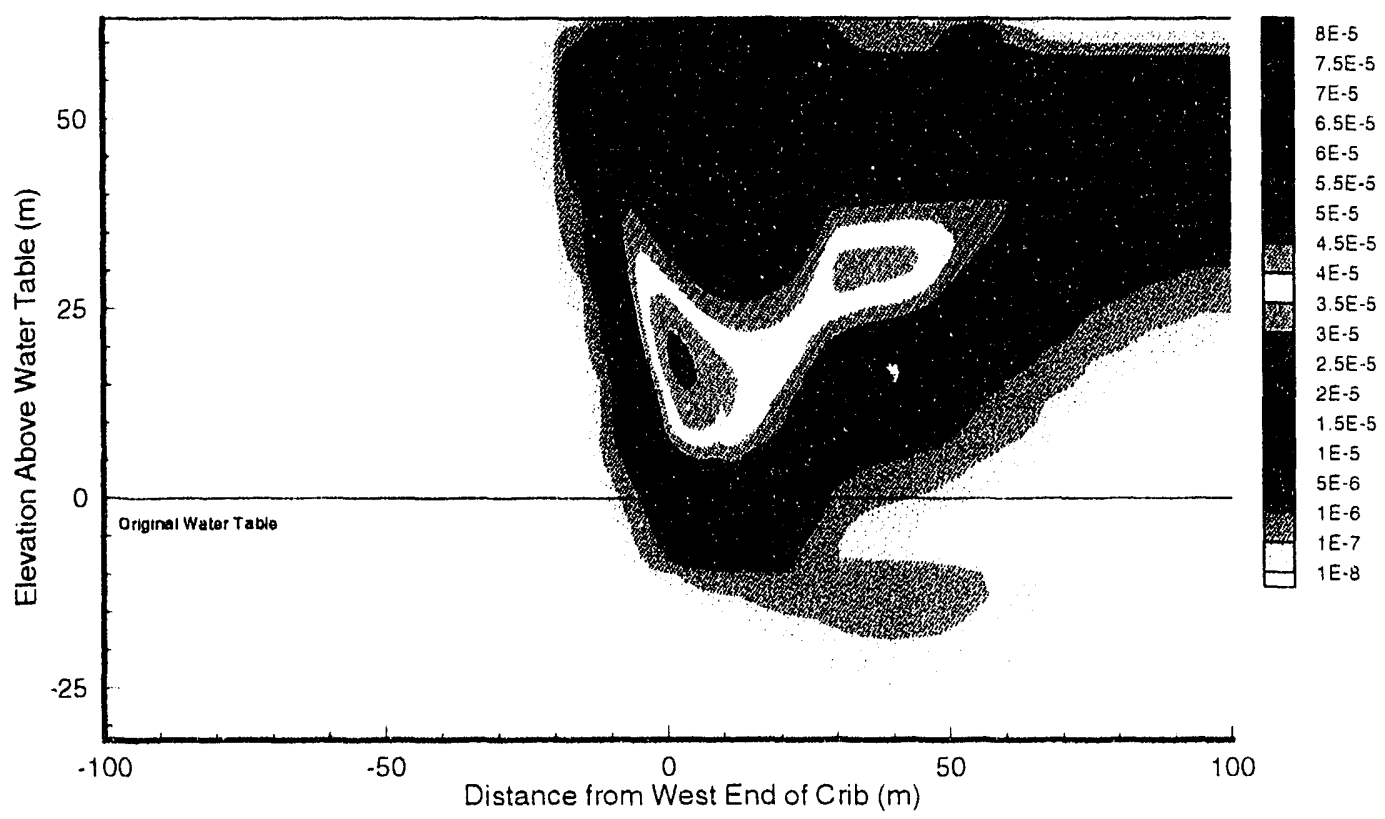

Figure 69. Simulation of 216-U-17 Crib - Construction of Best-

Estimate Case - Full Thickness and Actual Gradient in the Aquifer - Uranium Concentration Contours on January $31,2088$.

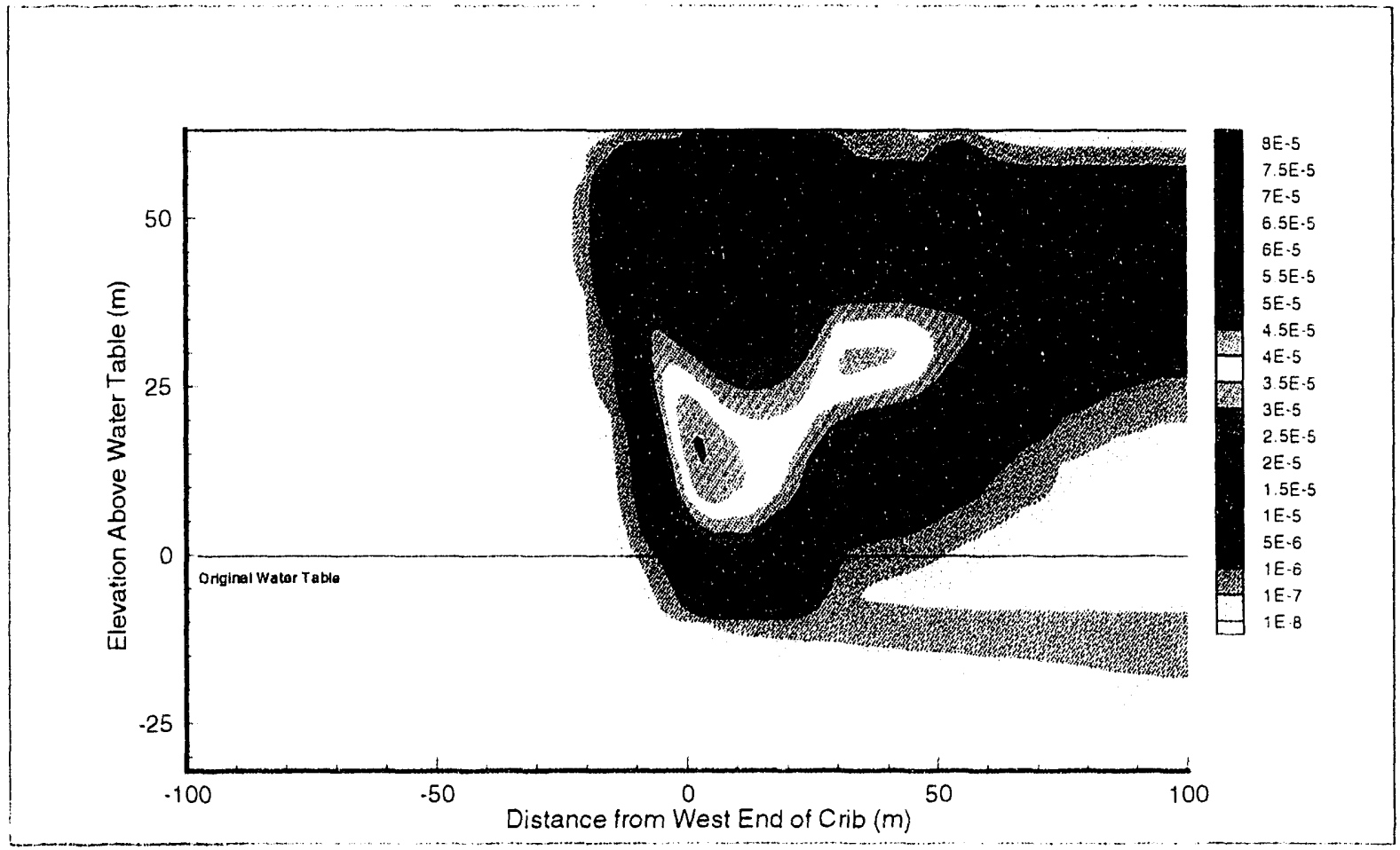


Aside from travel time, Figures 68 and 69 show that uranium concentrations up to $0.01 \mathrm{mg} / \mathrm{L}(10 \mathrm{ppb})$ remain in the crib backfill for at least 100 years after start of crib operation. This is virtually a guaranteed result of the numerical model since the PVC membrane over the gravel backfill is assumed to be perfectly impermeable for purposes of constructing the model. As indicated previously, recharge caused by precipitation becomes the principal driving force after discharges have ceased and discharged fluid has dissipated. Therefore, assumptions regarding degradation of the PVC membrane and associated recharge rate are incorporated into the best-estimate case.

For the best-estimate case, the initial steady-state flow field based on assumed recharge of $5 \mathrm{~cm} / \mathrm{yr}(q=5 \mathrm{~cm} / \mathrm{yr})$ to represent conditions before crib operation is intended to be consistent with an assumption that the crib site was devegetated. Before devegetation the 10cal recharge rate might have been an order of magnitude lower, but that is not accounted for in the model since for the first 10 or more years after the start of crib operation the flow field is dominated by crib discharges. During the period from February 1 , 1988 through January 31, 1998, the PVC membrane is assumed to be impermeable and admit zero flux of fluid from infiltration of precipitation. After 10 years it is assumed that the PVC membrane has deteriorated enough to admit $0.10 \mathrm{~cm} / \mathrm{yr}$ (a nominal amount). This is maintained in the model for almost 4 years (until December 31,2001 ) when assumed further deterioration admits $0.5 \mathrm{~cm} / \mathrm{yr}$ for another 2 years. After January 31, 2003 another step change to $1 \mathrm{~cm} / \mathrm{yr}$ is maintained for another 2-year period. By January 1, 2006 the recharge rate through the PVC membrane is assumed to be up to $2 \mathrm{~cm} / \mathrm{yr}$, while the recharge rate over the rest of the domain (away from the crib) is assumed to be down to $2 \mathrm{~cm} / \mathrm{yr}$ (from $5 \mathrm{~cm} / \mathrm{yr}$ ) because of revegetation or emplacement of a barrier. Finally, by January 1, 2008 the recharge rate is reduced to $1 \mathrm{~cm} / \mathrm{yr}$ uniformly in the model over the crib and surrounding site. This assumed recharge profile is summarized in Figure 70.

Uranium concentration contours after 50 and 100 years for this case with both the revised discharge and recharge rates are shown in Figures 71 and 72 , respectively. The slight arrival time delay induced by the revised discharge is likely offset by the use of nominal recharge after the turn of the century. This is demonstrated by comparing Figures 71 and 72 to Figures 68 and 69 . Because the assumed recharge rates are small, their effect should only be discernable over a much longer timeframe. The most prominent feature of Figures 71 and 72 (and 68 and 69) is the pronounced lateral extension of the plume by the gravel stringer (zone 3 ) in the upper Hanford formation and bifurcation of the center of the plume in the lower Hanford formation. Figure 71 also shows that uranium concentrations on the order of $0.01 \mathrm{mg} / \mathrm{L}$ arrive at the upper Ringold after the year 2038, and Figure 72 shows that concentration up to $0.02 \mathrm{mg} / \mathrm{L}$ arrive after the year 2088. Peak concentration in the plume $(0.05 \mathrm{mg} / \mathrm{L})$ in the year 2088 is still at least $15 \mathrm{~m}$ above the water table (in the lower Hanford formation). The moisture plume is effectively dissipated at that time; thus, with a recharge rate of $1 \mathrm{~cm} / \mathrm{yr}$, the expected travel time for that $15-\mathrm{m}$ distance is roughiy 1,500 years.

5.1.4.5.4 Anisotropy. Effective hydraulic conductivity in the model domain is treated as a heterogeneous, moisture-dependent quantity. Generally it is also regarded as being anisotropic (Freeze and Cherry 1979), although for the present simulation cases discussed previously it has been treated isotropically. In the past 10 years, numerous studies (e.g., Mualem 1984; 
Figure 70. Assumed Recharge Rate for 216-U-17 Crib Site and Polyvinyl Chloride Membrane.

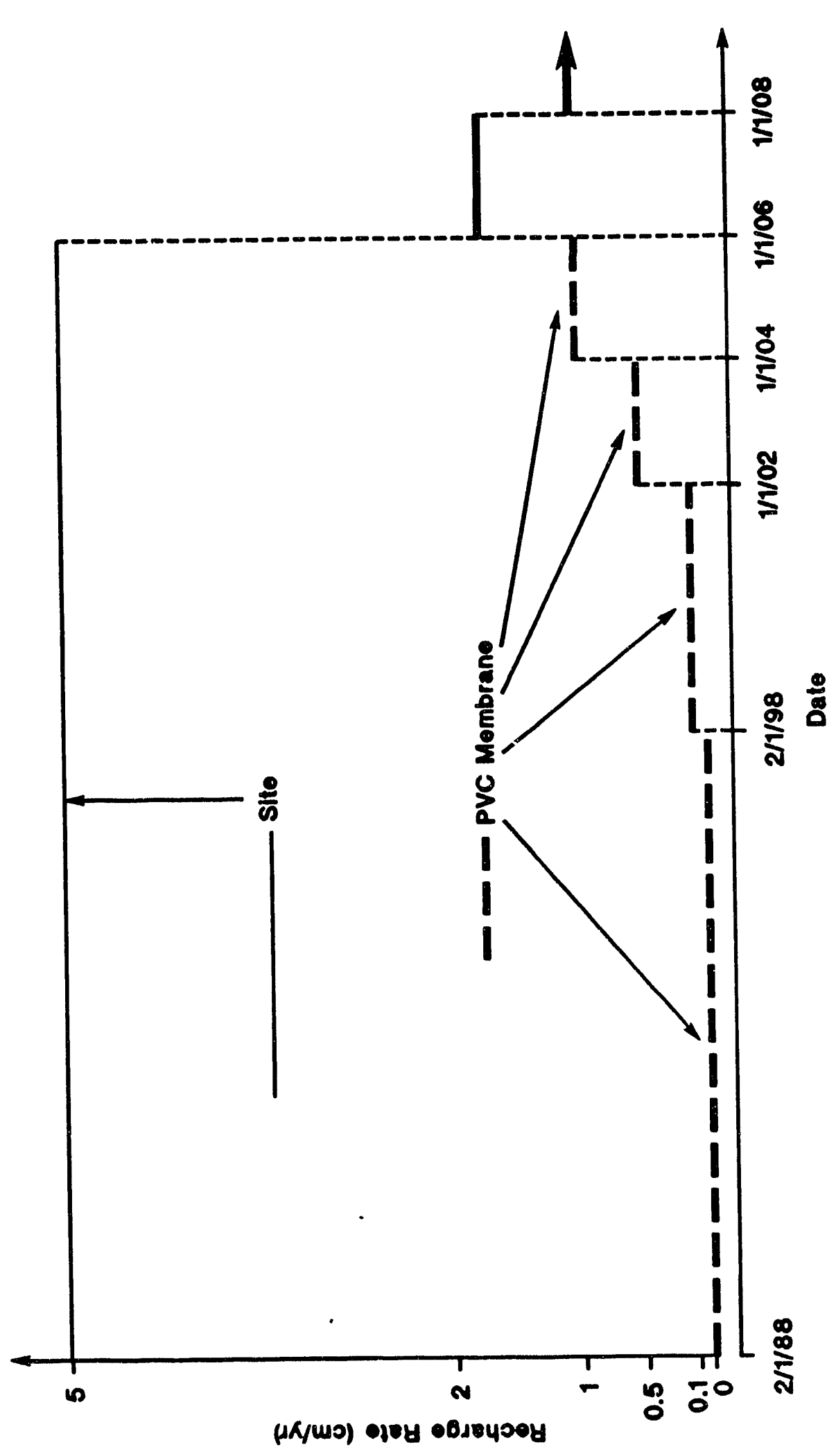


Figure 71. Simulation of 216-U-17 Crib - Construction of Best-Estimate Case - Revised Discharge and Recharge Rates - Uranium Concentration Contours on January 31, 2038.

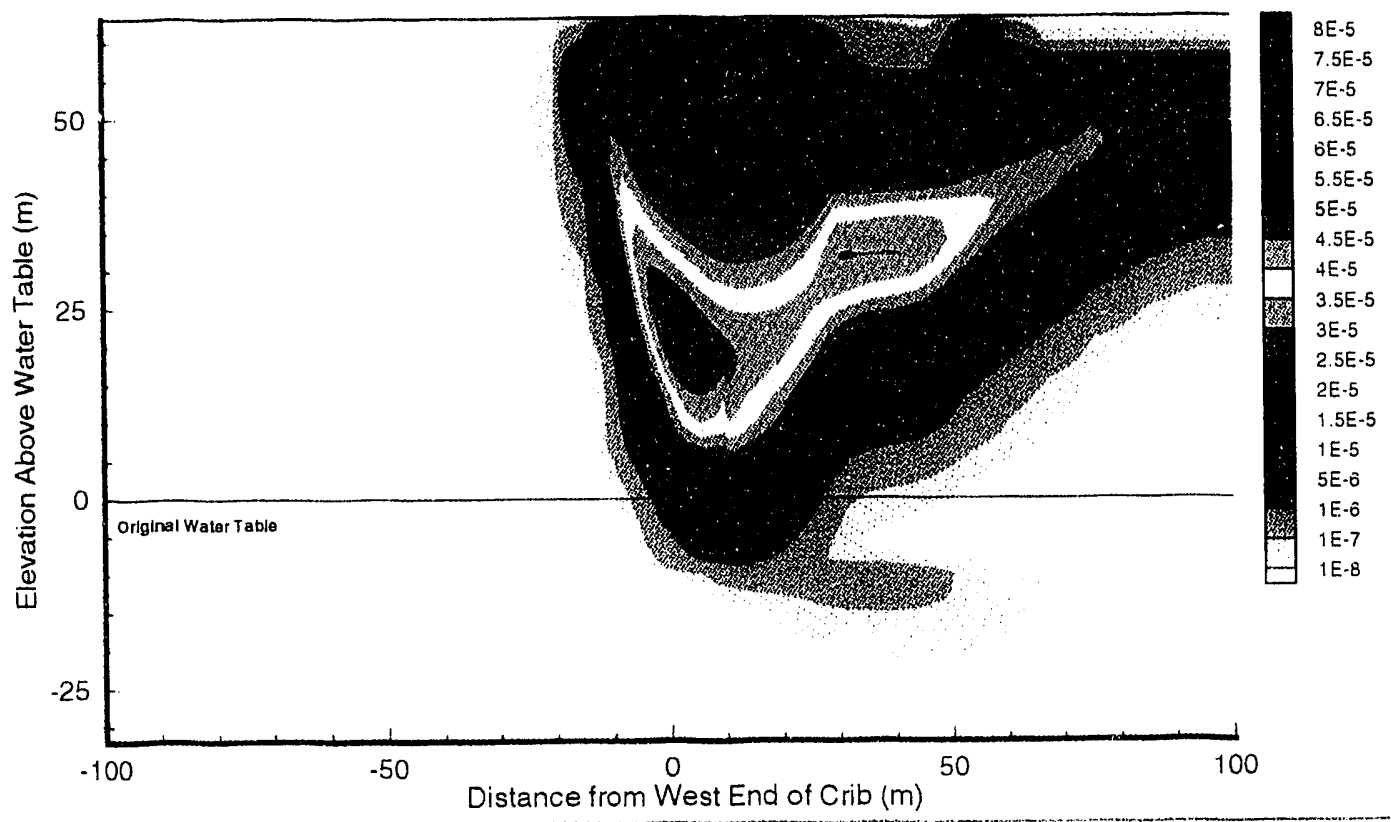

Figure 72. Simulation of 216-U-17 Crib - Construction of Best-Estimate Case - Revised Discharge and Recharge Rates - Uranium Concentration Contours on January 31, 2088.

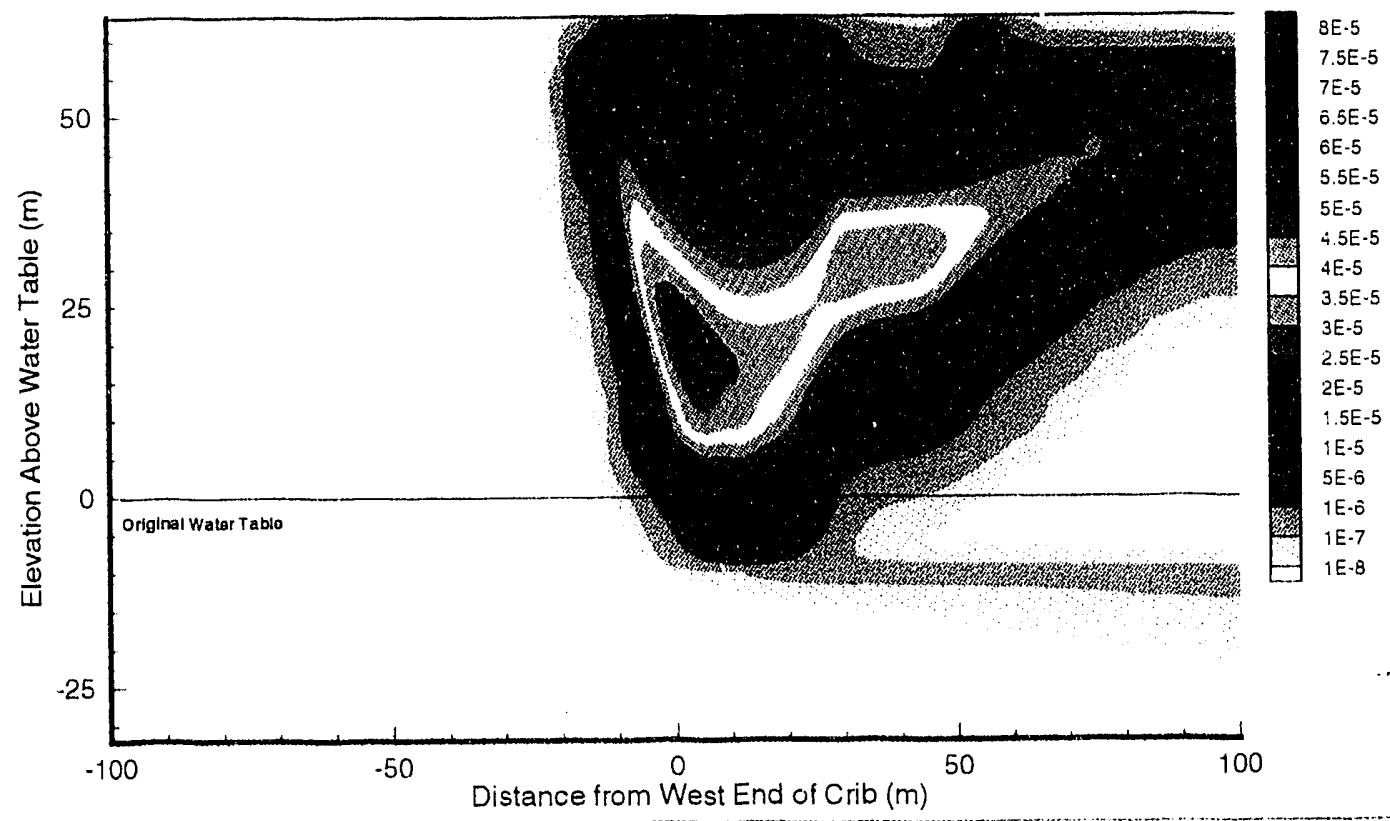


Yeh et al. 1985a, 1985b, 1985c; Bear et a1. 1987; and McCord et a1. 1991) have shown substantial evidence to indicate that anisotropy of homogeneous as we 11 as (layered) heterogeneous porous media is dependent on moisture content. Yeh et al. (1985a, 1985b, 1985c) al so conclude that anisotropy is dependent on hydraulic gradient, and suggest that anisotropy is enhanced by extensive bedding with many relatively thin layers. The consensus, especially for sandy soils (Yeh et a1. 1985c; Bear et a1. 1987; McCord et al. 1991), is that there is at least some nominal anisotropy at saturation which can decrease to near isotropy with some reduction in moisture content and then increase with further reduction in moisture content. Generally the highest anisotropies are expected at the driest conditions.

The so-called "Direct Average Method" for approximating the average anisotropy (Yeh et al. 1985c) is simply to take the ratio of the arithmetic mean conductivity to the harmonic mean. Using the saturated conductivities in Table 8, the arithmetic mean is $K_{a}=1302.9 \mathrm{~m} / \mathrm{yr}$ and is dominated by the gravelly layers that provide lateral conduits. The harmonic mean conductivity from Table 8 is $K_{h}=6.36 \mathrm{~m} / \mathrm{yr}$, which is more reflective of the finer-grained layers. The direct average anisotropy is $a=K_{a} / K_{h}$, and has a value of over 200. This "average" value is likely extreme for mid-range volumetric moisture content (Yeh et al. 1985a, 1985b, 1985c), but an underestimate for dry conditions. A nominal value of average anisotropy, $a=10$, was assumed for the best-estimate case. The global constant anisotropy was implemented by setting the horizontal saturated conductivity to $K_{\text {saf }}$ from Table 8 and setting the vertical saturated conductivity to $\mathrm{K}_{\text {sat }} / 10$. (Using $\mathrm{K}_{\text {sat }}$ from Table 8 for vertical saturated conductivity and $10 \mathrm{~K}_{\text {sat }}$ for the horizontal produces similar results.)

Mccord et al. (1991) demonstrate that assuming constant average anisotropy can lead to unrealistic simulation results, particularly for a short-term release event in inclined layers. Yeh et a1. (1985a, 1985b, 1985c) argued that assuming isotropy or constant average anisotropy can lead to overestimated vertical penetration and underestimated lateral migration of wetting fronts and contaminant plumes. Therefore the best-estimate case, as defined to this point with the two-dimensional planar domain and nominal constant anisotropy, is still regarded as being conservative in that it likely underestimates travel times to the water table. Conversely, underestimation of lateral migration because of assumption of nominal constant anisotropy is compensated by the constraints of the two-dimensional simulation domain.

The final refinement to the best-estimate case is implementation of the leaky boundary conditions for flow on the north and south faces of the domain. This allows seepage of fluid and, hence, advection of solute through the north and south faces, but only at saturation. The effect of the additional leaky boundary conditions on the wetting-drying history in the Hanford formation sand at the node immediately under the crib floor directly below the point source is shown in Figure 73. Curve 1 in Figure 73 indicates that drainage immediately under the crib evolves to a steady condition after more than 200 years. Compared to curve 1 in Figure 62 this is about an order of magnitude greater than predicted by the base case, which is the effect of the assumed anisotropy $(a=10)$. Curve 2 in Figure 73 shows the additional effect of some north-south spreading from the leaky boundary conditions and suggests about 100 years are required for evolution of steady conditions under the crib. Similar dryout times are indicated at lower elevations as well because the principal direction of flow is lateral rather than vertical. The other 
Figure 73. Simulation of 216-U-17 Crib-Best-Estimate Case - Time History of Relative Saturation.

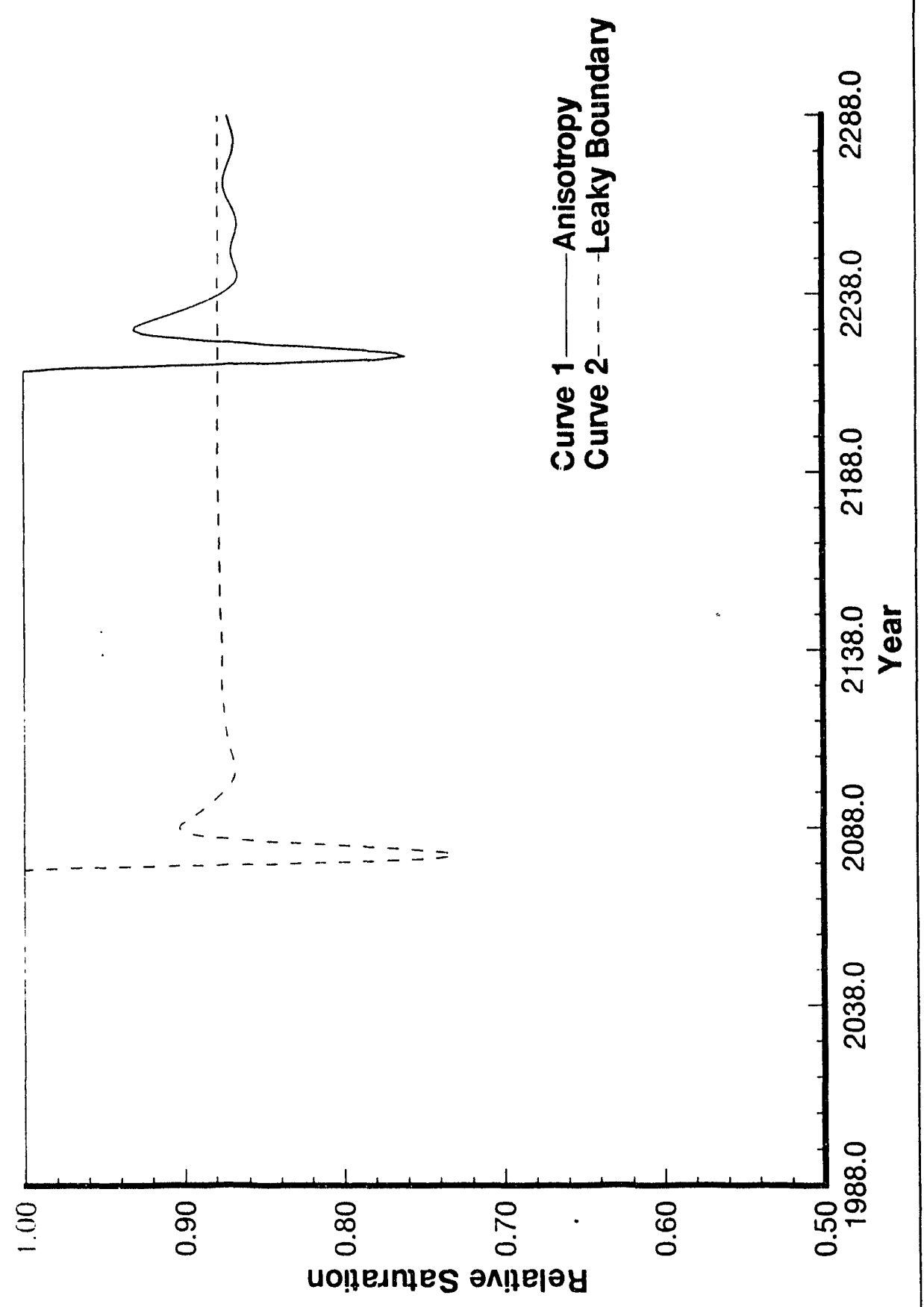


prominent distinction between Figures 73 and 62 is that with the assumption of degradation of the PVC membrane, the soil under the crib doesn't dry as much (see Figure 73) as under the base case assumption of a permanent recharge shadow.

5.1.4.5.5 Best-Estimate Case Results. Results from the best-estimate case emphasize lateral migration and the importance of recharge rate. A sequence of plots showing relative saturation contours from the bestestimate case at 10,30, 100, and 300 years after start of crib operation are shown in Figures 74 through 77, respectively. Figures 74 and 75 indicate that effluent discharged to the $216-\mathrm{U}-17 \mathrm{Crib}$ spreads laterally, slowly, and remains effectively confined in the uppermost layers of the Hanford formation for at least 30 years. Figure 76 shows dryout of the soil immediately under the crib after 100 years (see Figure 73), and a broad plume (radius $>50 \mathrm{~m}$ ) of modestly elevated moisture content extending from a few meters under the crib backfill down through the Hanford formation into the early "Palouse" soil. Figure 76 also suggests the possibility of perched water over the gravel stringers in the Hanford formation and some ponding over the Plio-Pleistocene unit. Figure 77 suggests that the soil column has returned to near steady state (see Figure 59), but with slightly elevated moisture content to the west of the crib, especialiy in the upper layer of the Hanford formation (zone 2) through which much of the effluent discharges were dissipated.

The best-estimate uranium plume also is shown at $10,30,100$, and 300 years in Figures 78 through 81 respectively. With $K_{d}=1 \mathrm{~cm}^{3} / \mathrm{g}$, the uranium plume develops about half as fast as the moisture plume. After cessation of crib discharges in June 1995, the dissipating moisture plume leaves significant concentrations of uranium trapped behind in the uppermost Hanford formation to be driven downward even more slowly by seepage from assumed recharge caused by net infiltration of precipitation (see figure 70 ). Initial development of the uranium plume is shown at 10 years after beginning of crib operation in Figure 78. Peak uranium concentrations indicated by Figure 78 are on the order of $0.05 \mathrm{mg} / \mathrm{L}$ (about $50 \mathrm{ppb}$ ) no more that $10 \mathrm{~m}$ from the crib backfill within the first 10 years. Streamlines from the flow field, at the same time in Figure 78, show the lateral spreading both to the east and west from the ends of the crib and also show bending into the (wetted) gravel stringer (zone 3) in the upper Hanford formation and around the (dry) gravel stringer (zone 7) to the west in the lower unit of the Hanford formation. Maximal lateral gradients are indicated after 30 years by streamlines in Figure 79, but migration of uranium is still retarded by sorption $\left(K_{\mathrm{d}}=1 \mathrm{~cm}^{3} / \mathrm{g}\right)$. After 100 years the uranium plume is effectively developed to full extent as shown in Figure 80, and streamlines indicate that further migration is principally downward due to recharge. The streamlines in Figure 80 also show some bending in the early "Palouse" soil because of the lateral dissipation of ponded water over the Plio-Pleistocene unit. Figure 81 shows that further development of the uranium plume is affected about as much by diffusion as by the driving force from assumed recharge. After 300 years the peak simulated uranium concentration is on the order of about $10 \mathrm{ppb}$ and still resides within about $15 \mathrm{~m}$ beneath the floor of the crib. A uranium concentration greater than $1 \mathrm{ppb}$ is predicted to remain within $25 \mathrm{~m}$ vertically from the floor of the crib during the first 300 years after operation of the 216-U-17 crib. With a $K_{d}$ of $0.5 \mathrm{~cm}^{3} / \mathrm{g}$ for uranium, arrivals at the 1988 water table are only up to $5 \mathrm{ppb}$ within a thousand years. 
WHC-EP-0664

This page intentionally left blank. 
Figure 74. Simulation of $216-U-17$ Crib - Best-Estimate Case - Relative Saturation Contours on January 31, 1998

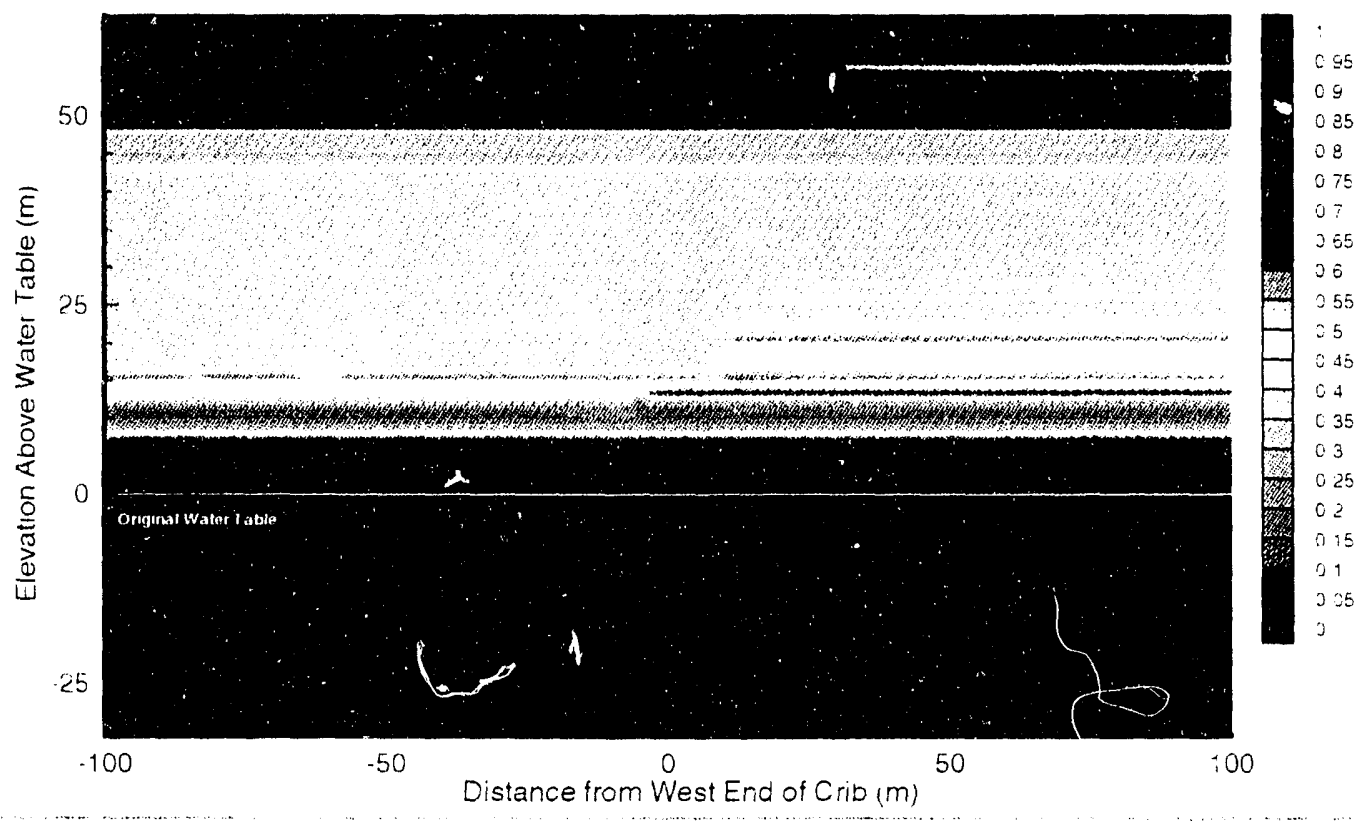

Figure 75. Simulation of 216-U-17 Crib - Best-Estimate Case - Relative Saturation Contours on January 31, 2018.

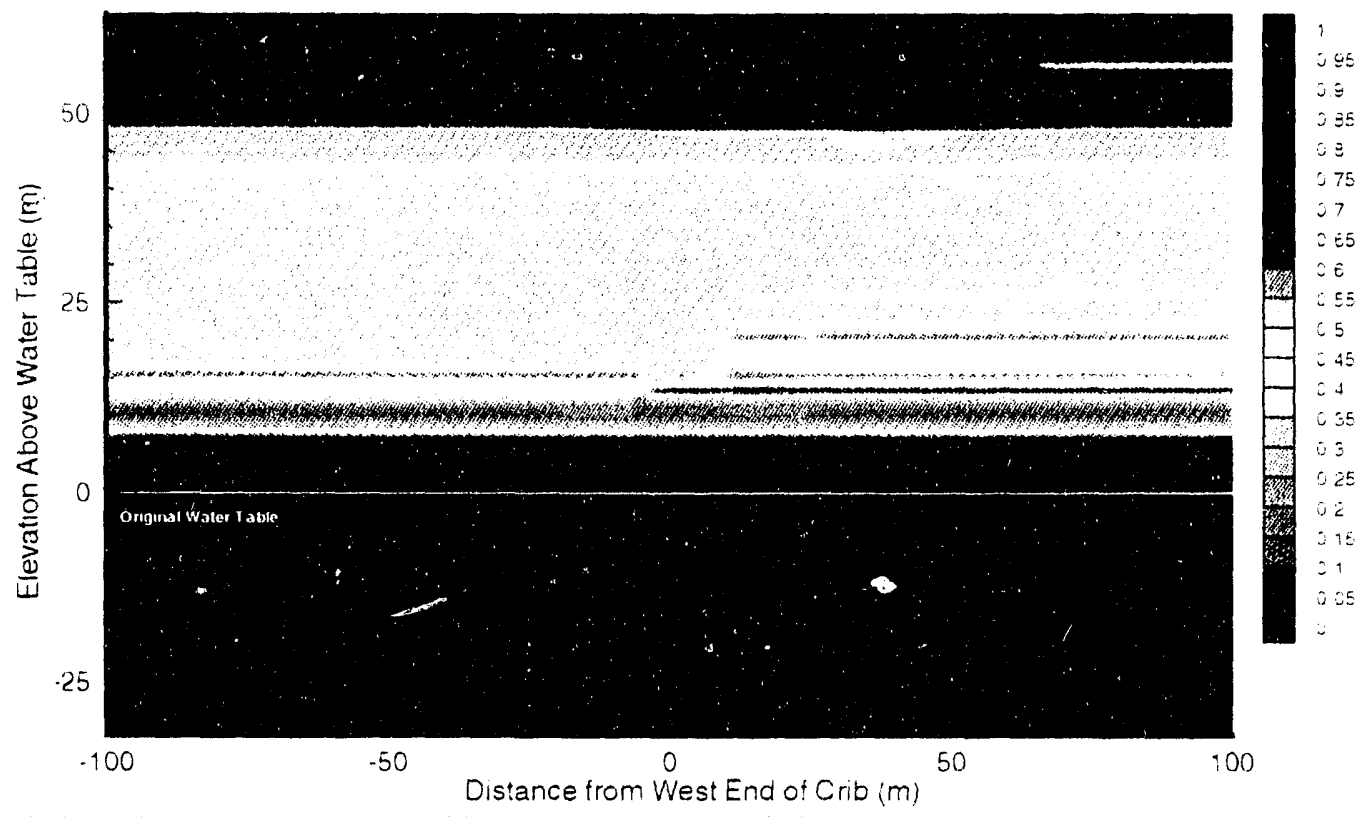

$133 / 134$ 
Figure 76. Simulation ct 216-U-17 Crib - Best-Estimate Case - Relative Saturation Contours on January 31,2088

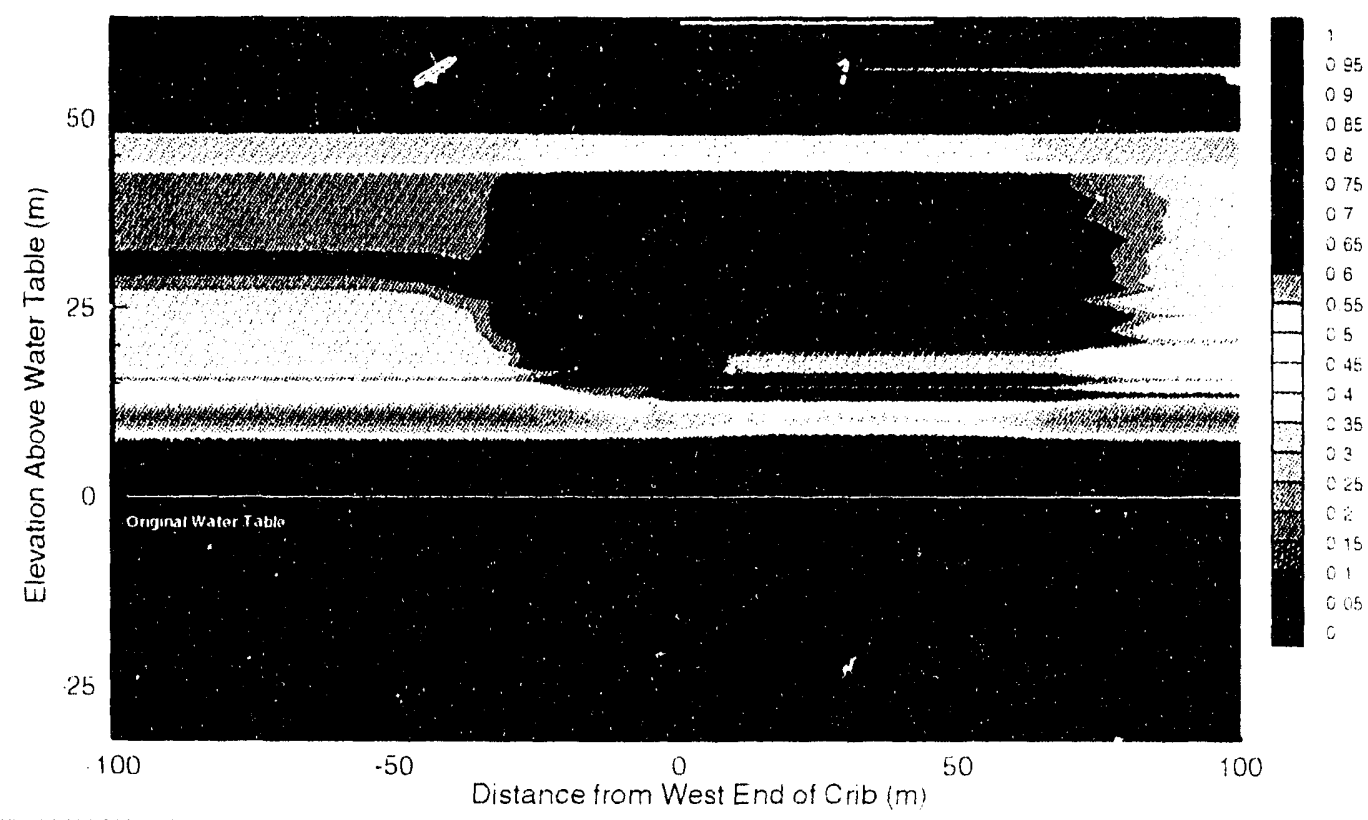

Figure 77. Simulation of 216-U-17 Crib - Best-Estimate Case - Relative Saturation Contours on January 31,2288

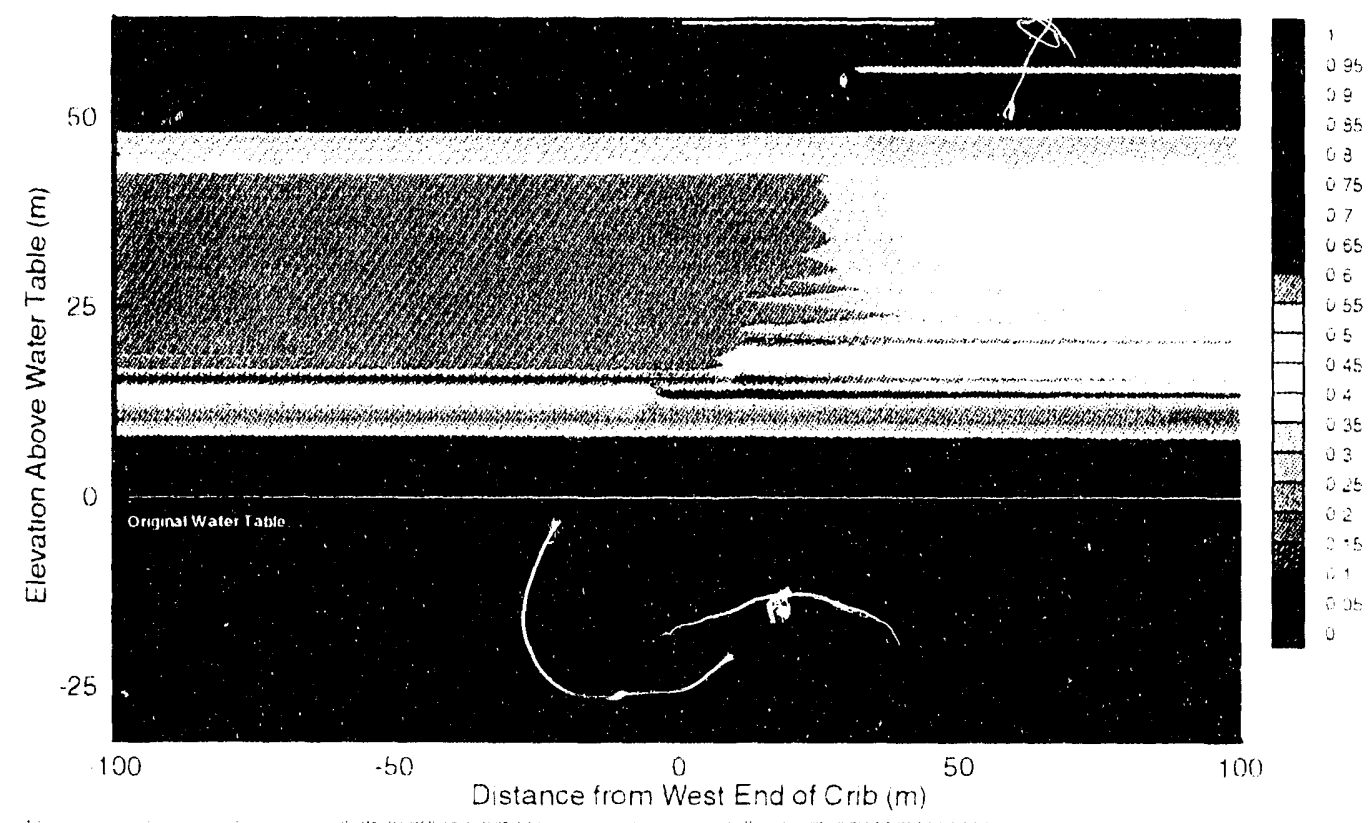

$135 / 136$ 
Figure 78. Simulation of 216-U-17 Crib - Best-Estimate Case - Uranium Concentration Contours on January 31, 1998.

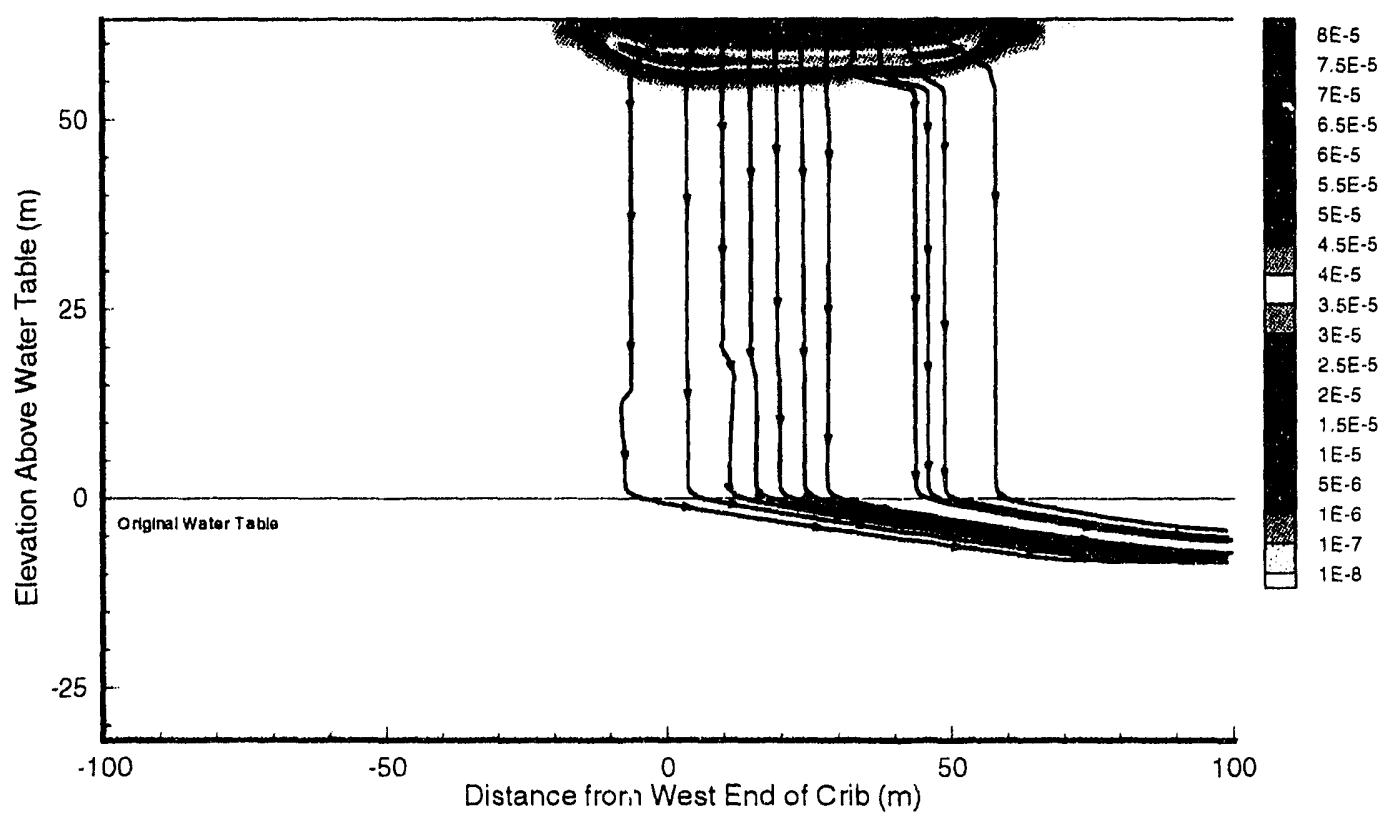

Figure 79. Simulation of 216-U-17 Crib - Best-Estimate Case - Uranium Concentration Contours on January 31, 2018.

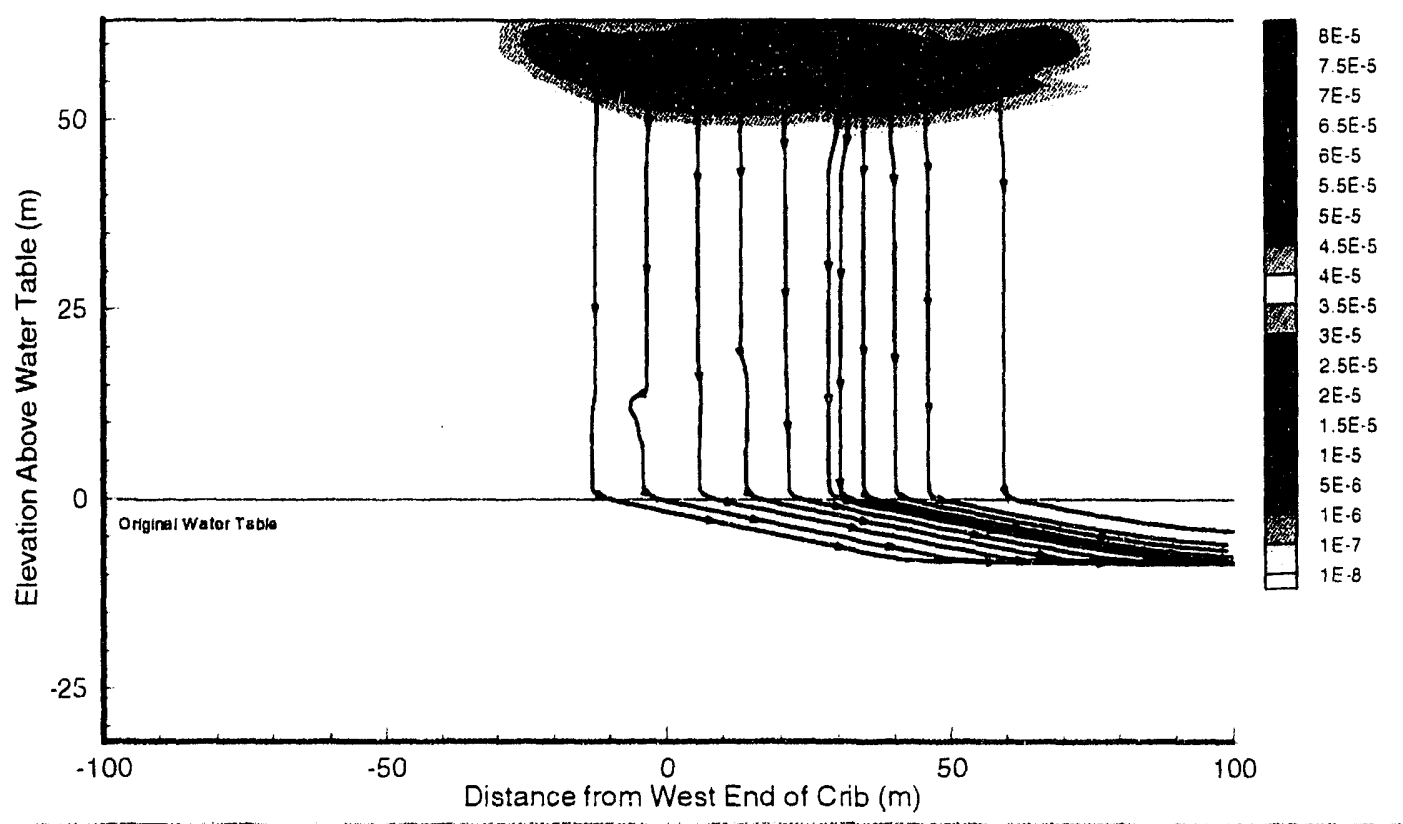


Figure 80. Simulation of 216-U-17 Crib - Best-Estimate Case - Uranium Concentration Contours on January $31,2088$.

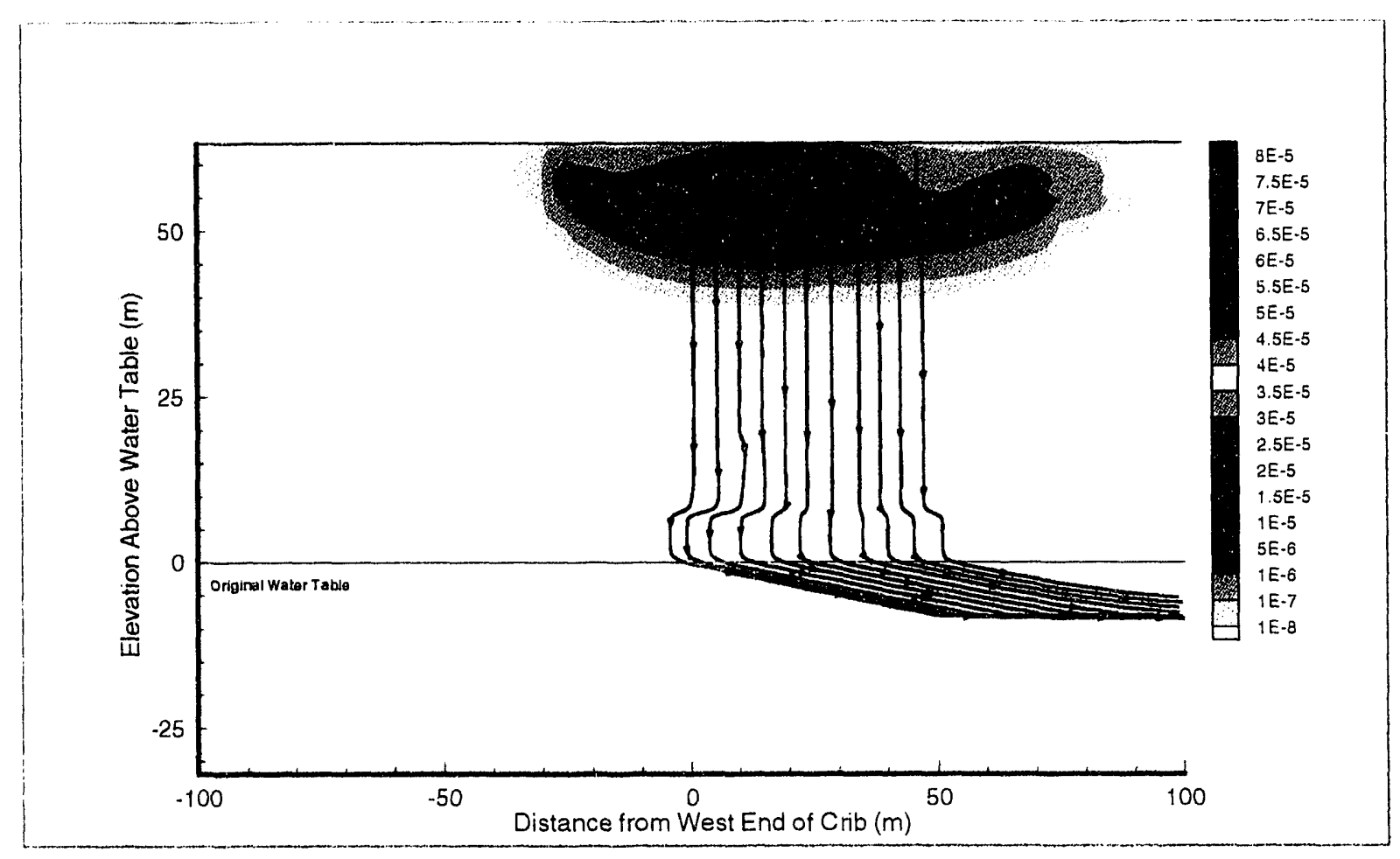

Figure 81. Simulation of 216-U-17 Crib - Best-Estimate

Case - Uranium Concentration Contours on January 31, 2288.

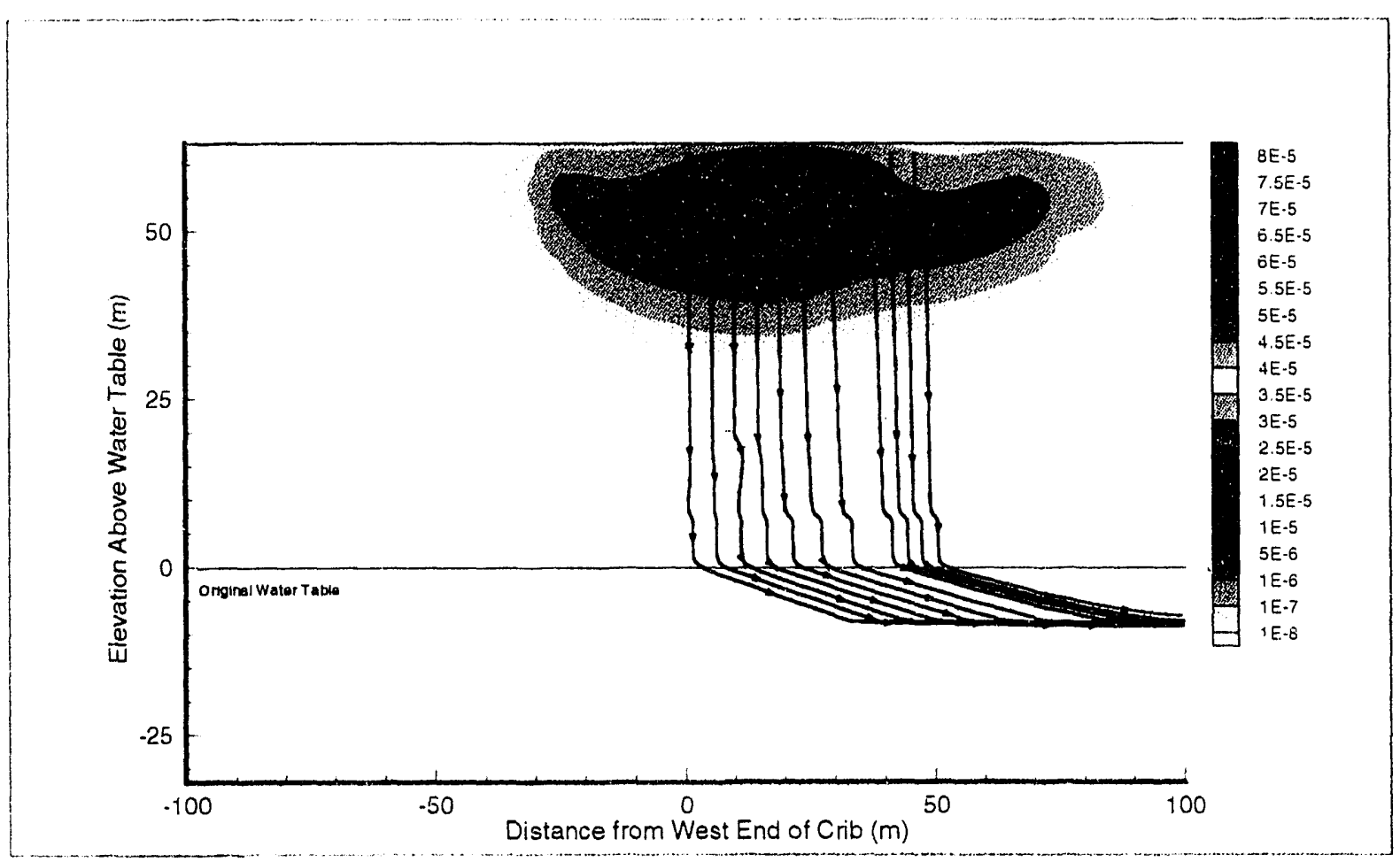


5.1.4.5.6 Best Estimate Technetium-99 Transport. The best-estimate case discussed in Sections 5.1.4.5.4 and 5.1.4.5.5 was also run to simulate transport of ${ }^{99} \mathrm{TC}$ under the assumptions of no decay and no sorption $\left(K_{d}=0\right)$. Modifications to the concentration boundary condition at the point source to reflect incoming ${ }^{99} \mathrm{Tc}$ in the process condensate stream are as follow (see Table 14):

$$
\begin{aligned}
& \text { Run 15: } C=0.008 \mu \mathrm{Ci} / \mathrm{L} \\
& \text { Run 16: } C=0.0013 \mu \mathrm{Ci} / \mathrm{L} \\
& \text { Run 17: } C=0.0013 \mu \mathrm{Ci} / \mathrm{L} \\
& \text { Standby: } C=0.0009 \mu \mathrm{Ci} / \mathrm{L} .
\end{aligned}
$$

The results of this case are best summarized by the concentration contour plot in Figure 82 , which shows the ${ }^{99}$ Tc distribution at 1,000 years after the start of crib ogeration. In particular, Figure 82 indicates that the center of mass of the ${ }^{59} \mathrm{Tc}$ plume is still above the original (1988) water table after 1,000 years and that the peak concentration is less than $4.0 \times 10^{-5} \mu \mathrm{Ci} / \mathrm{L}$ $(40 \mathrm{pCi} / \mathrm{L})$. Hence, even though ${ }^{9} \mathrm{Tc}$ is assumed to be perfectly mobile, arrival at the unconfined aquifer is dominated by the anisotropy of the medium and the low recharge rate.

The ratio of the upper bound ${ }^{99} \mathrm{Tc}$ concentration, which can enter the unconfined aquifer $\left(\leq 4.0 \times 10^{-5} \mu \mathrm{Ci} / L\right)$ to the upper bound ${ }^{99} \mathrm{Tc}$ concentration in the process condensate stream $(0.008 \mu \mathrm{Ci} / \mathrm{L})$ is about $0.6 \%$. Because ${ }^{99} \mathrm{Tc}$ is assumed to be conservative (no decay, no sorption), the relative peak concentration $(0.6 \%)$ can be used to infer peak nitrate concentration entering the aquifer (because nitrate is also assumed to be conservative). That same relative peak concentration can as well be used to estimate peak concentrations of other conservative species at the original (1988) water table under the best-estimate case assumptions.

\subsection{HYDRAULIC IMPACTS - A SUMMARY}

Under the most conservative modeling assumptions, the results presented here suggest that the wetting front from discharges to the $216-U-17 \mathrm{Crib}$ arrives at the 1988 water table after about 6 years (1994). Under similarly conservative assumptions, previous modeling predicted arrival of the wetting front at the water table in about 17 years (WHC 1990a).

Under more realistic, best-estimate parameters that take into account at least nominal average anisotropy and some approximation to lateral spreading in the north-south as well as east-west directions, the wetting front does not arrive at the water table for about 100 years.

Arrival of the wetting front at the water table is an evolutionary process that is controlled primarily by the layered nature of the sediments. Smaller scale heterogeneities that are not well characterized also affect rates and paths of percolation through the sediments. It is important to note that the base case simulations, previous modeling (WHC 1990a), and the bestestimate case simulation all show substantial lateral spreading of the effluent through the stratigraphy. By the time the simulated wetting front 
WHC-EP-0664

This page intentionally left blank. 
Figure 82. Simulation of 216-U-17 Crib - Best-Estimate Case - Technetium Concentration Contours on January $31,2988$.

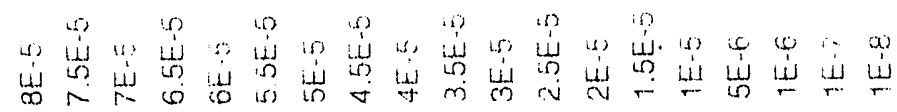

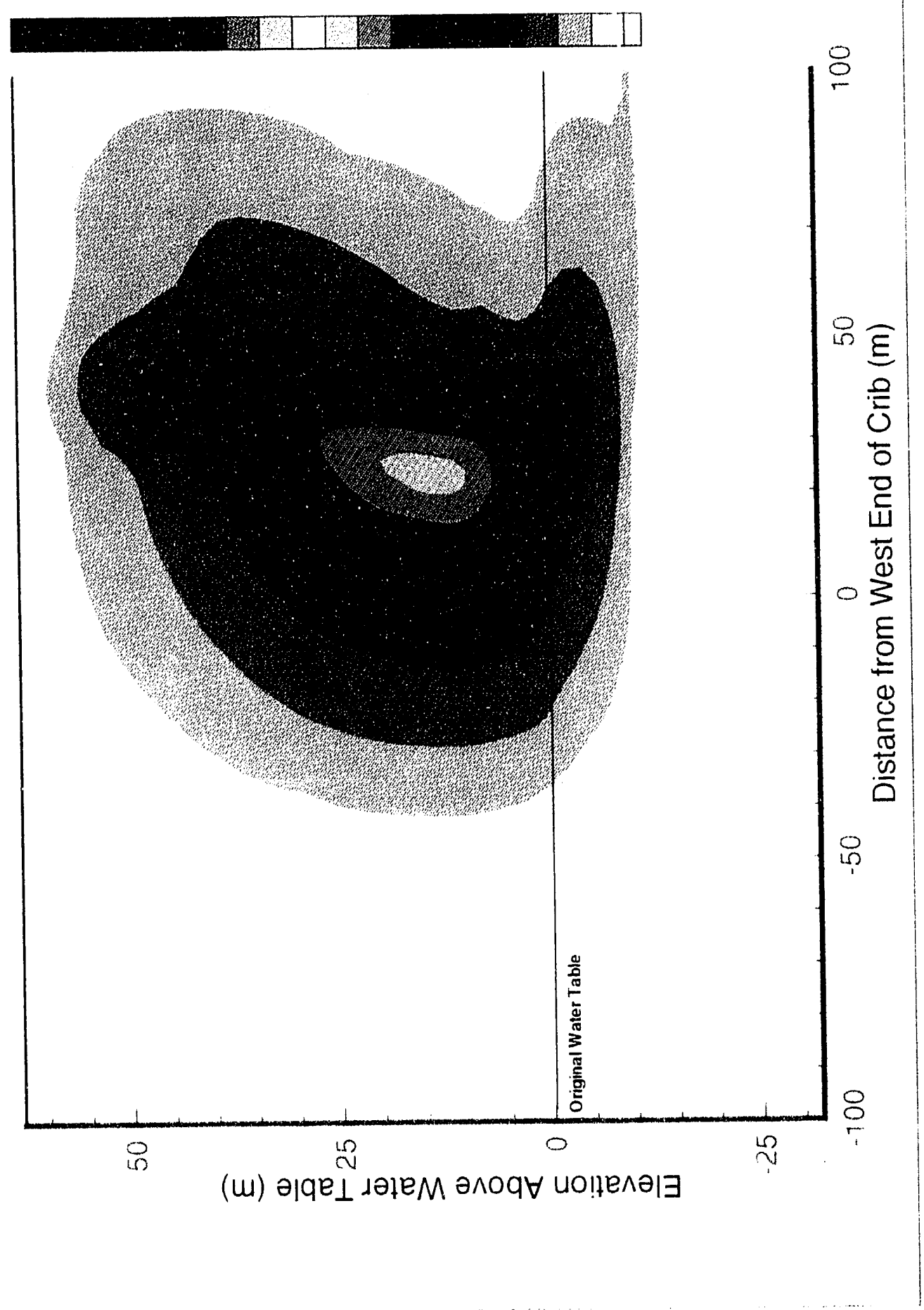


does arrive at the water table, the volume of moistened soil is broader and more diffuse than those predicted previously for other crib sites (e.g., 216-A-30, A-37-1, and A-37-2 in the 200 East Area [WHC 1990a]; 1301-N and 1325-N in the 100 Area [Connelly et al. 1991]).

Initially lateral spreading is affected not only by moisture-dependent anisotropy, but al so by dry, coarse layers that divert downward flow until wetted, and then conduct horizontal flow preferentially. All of the base case and best-estimate cases reported here indicate that after the sediments have been wetted and have subsequently dried to near equilibrium condition, gravel stringers in the Hanford formation might hold back some perched water. A11 cases suggest at least some ponding eventually in the early "Palouse" soil over the Plio-Pleistocene unit. Under the conservative base case conditions, mounding in the Plio-Pleistocene unit occurs. Generally, ponded/mounded water is dissipated within 100 years of arrival. The net impact is that moisture front arrivals at the water table are not expected before the year 1994 (conservative assumptions), and likely will be no later than the year 2100 (most realistic assumptions). Some transient ponding and even mounding is possible, but near-equilibrium conditions should be expected within 300 years. Perched water over gravel stringers in the Hanford formation could be persistent.

\subsection{CONTAMINANT IMPACTS - A SUMMARY}

Under conservative base case assumptions, arrivals of peak concentrations of conservative species (no retardation, no decay) at the water table are not expected before the year 2000. Maximum peak concentrations of conservative species arriving at the water table are about $75 \%$ of the original concentrations in the effluent discharged to the $216-\mathrm{U}-17 \mathrm{Crib}$. For ${ }^{89} \mathrm{Tc}$, this translates into an absolute maximum concentration of $0.006 \mu \mathrm{Ci} / \mathrm{L}(6,000 \mathrm{pCi} / \mathrm{L})$ arriving at the water table (from run 15). Those peak arrivals are of short duration (hours or days). Generally, arrivals of ${ }^{99} \mathrm{Tc}$ are expected to be in much more dilute concentrations and at much later times consistent with arrival of the wetting front.

A uranium plume is predicted to develop in the vadose zone, but more slowly than the moisture plume because of retardation caused by nominal sorption $\left(K_{g}\right.$ approximately equals $1 \mathrm{~cm}^{3} / g$ ). As the moisture plume dissipates, the retarded uranium plume becomes entrapped in the upper layers of the Hanford formation. Uranium is then effectively immobilized except for gradual diffusion and minimal advective transport caused by recharge. Under conservative base case conditions, using soil column loading history, peak uranium arrivals at the water table should not exceed $30 \mu \mathrm{g} / \mathrm{L}(20 \mathrm{pC} \mathrm{i} / \mathrm{L})$; however, under expected conditions, there will be no arrivals of uranium at the water table for at least several hundred years.

\subsection{IMPACT OF EFFLUENT DISCHARGE AT 216-U-17 CRIB ON THE GROUNDWATER}

The potential significance of predicted concentrations in groundwater from continued disposal to the ground are evaluated by comparison with either (1) WAC 173-200 standards or (2) DOE-derived concentration guides (4 mrem/yr equivalent) for those radionuclides not included in WAC 173-200 (Tyler 1991). 
The relevant guidelines for constituents of interest in effluent discharged to the 216-U-17 Crib are listed in Table 16.

Table 16. Concentration Guides for Evaluation Potential Groundwater-Impacts at the 216-U-17 Crib.

\begin{tabular}{|c|c|c|c|}
\hline Constituent & Concentration & Units & Source \\
\hline Tritium & 20,000 & $\mathrm{pCi} / \mathrm{L}$ & WAC 173-200 \\
\hline TC-99 & 4,000 & $\mathrm{pCi} / \mathrm{L}$ & $1 / 25$ DCG \\
\hline Gross beta & 50 & $\mathrm{pCi} / \mathrm{L}$ & WAC 173-200 \\
\hline Gross alpha & 15 & $\mathrm{pCi} / \mathrm{L}$ & WAC 173-200 \\
\hline U-234,238 & 24 & $\mathrm{pCi} / \mathrm{L}$ & $1 / 25$ DCG \\
\hline Fluoride & 4 & $\mathrm{mg} / \mathrm{L}$ & WAC 173-200 \\
\hline Nitrate & 45 & $\mathrm{mg} / \mathrm{L}$ & WAC 173-200 \\
\hline Chiromium & 50 & $\mu \mathrm{g} / \mathrm{L}$ & WAC 173-200 \\
\hline
\end{tabular}

$D C G=$ derived concentration guide.

WAC 173-200, 1990, "Water Quality Standards of the State of Washington," Washington Administrative Code, as amended.

On the basis of the highly conservative model predictions summarized in Table 7, effluent arrives at the water table within 7 years at peak concentrations of about $75 \%$ of the effluent concentrations. Multiplying 0.75 times the maximum values observed during the most recent operation of the $\mathrm{UO}_{3} \mathrm{Plant}$ facilities (Figures 83 through 86 ) suggests some possible groundwater exceedances. These are worst-case or upper-bound estimates of potential groundwater impact and are not considered realistic for several reasons. First, no allowance is made for mixing with ambient groundwater or tritium decay and only the maximum concentrations were used. Use of average effluent concentrations and concentrations during operation of the fiber mist eliminator yields significantly lower values, especially for uranium and related salts (nitrate and fluoride). Similar conclusions result from predictions using the input source contaminant values estimated from prior operating runs as summarized in Table 7.

With allowance for anisotropy, a major feature of the best-estimate case, first arrival of the wetting front and tritiated water does not occur for 125 years. This results in decay of the tritium to about $20,000 \mathrm{pCi} / \mathrm{L}$ (about 10 half-lives) or very close to the present guideline value $(20,000 \mathrm{pCi} / \mathrm{L})$. In addition, dilution of tritium and other mobile constituents with soil moisture occurs because lateral spreading distributes the constituents throughout a larger volume of the vadose zone. Mobile contaminants such as ${ }^{99}$ Tc reach the water table after 1,000 years with predicted peak concentrations of $40 \mathrm{pCi} / \mathrm{L}$ compared to the derived concentration guide of $4,000 \mathrm{pCi} / \mathrm{L}$; nitrate has a peak concentration of $90 \mathrm{mg} / \mathrm{L}$ compared to the WAC $173-200$ groundwater criteria of $45 \mathrm{mg} / \mathrm{L}$. Initial mixing in groundwater will reduce concentrations to less than the guideline values. 
Figure 83. Apri7-May 1993 Process Condensate Concentrations from - Tank X-37 with Fiber Mist El iminator On and Off for

(A) [upper left] Technetium-99 in $\mu \mathrm{Ci} / \mathrm{L}$, (B) [upper right] Uranium in $\mathrm{g} / \mathrm{L}$, (C) [1ower left] $\mathrm{pH}$, and (D) [lower right] Nitrate Molarity.
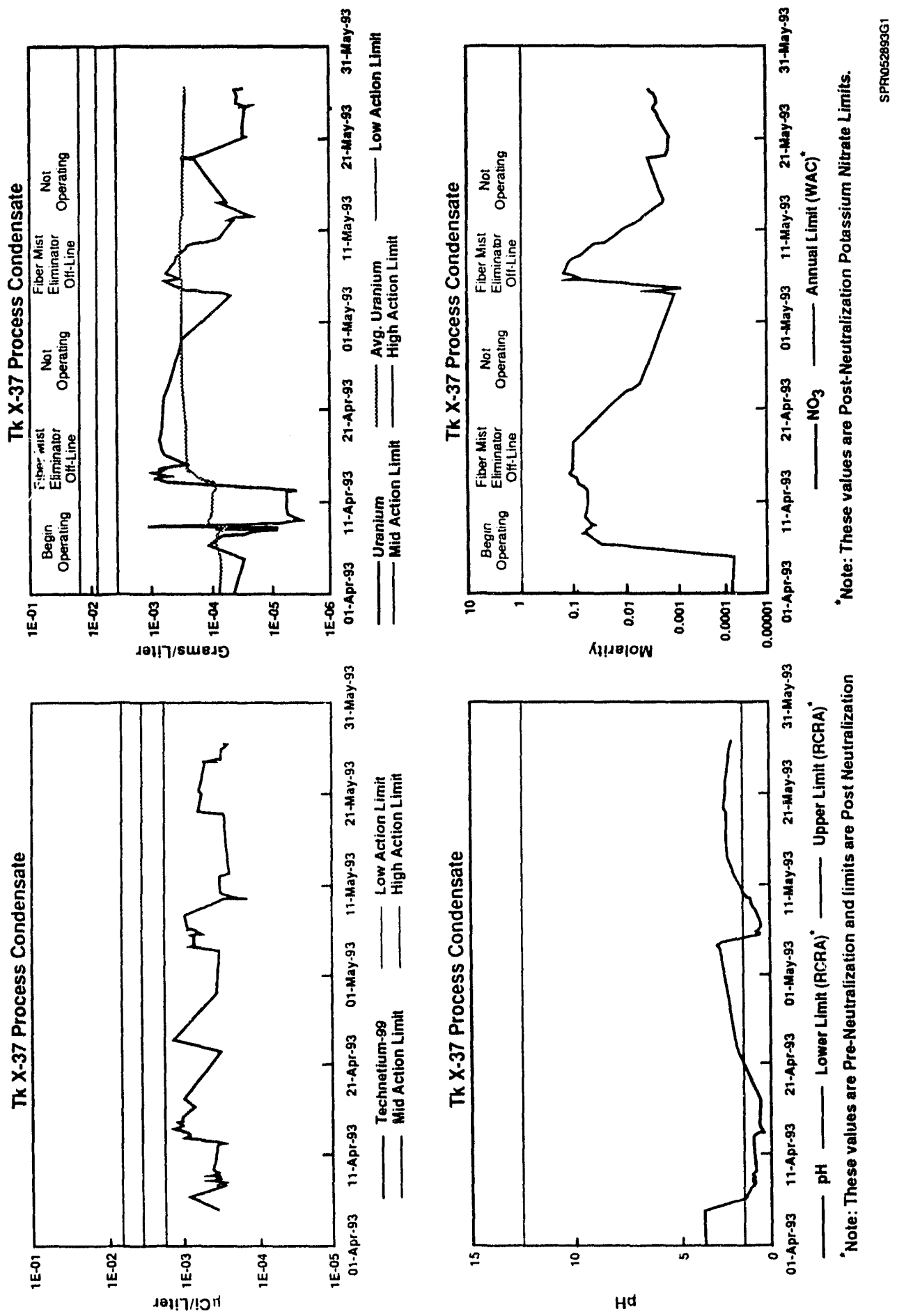
Figure 84. August 1992 - May 1993 Process Condensate Concentrations at 216-U-17 Crib for (A) [upper left] Gross Alpha in $\mu \mathrm{Ci} / \mathrm{L}$, (B) [upper right] Potassium in $\mathrm{mg} / \mathrm{L}$, (C) [lower left] Gross Beta in $\mu \mathrm{Ci} / \mathrm{L}$, and (D) [lower right] Potassium Nitrate Molarity.
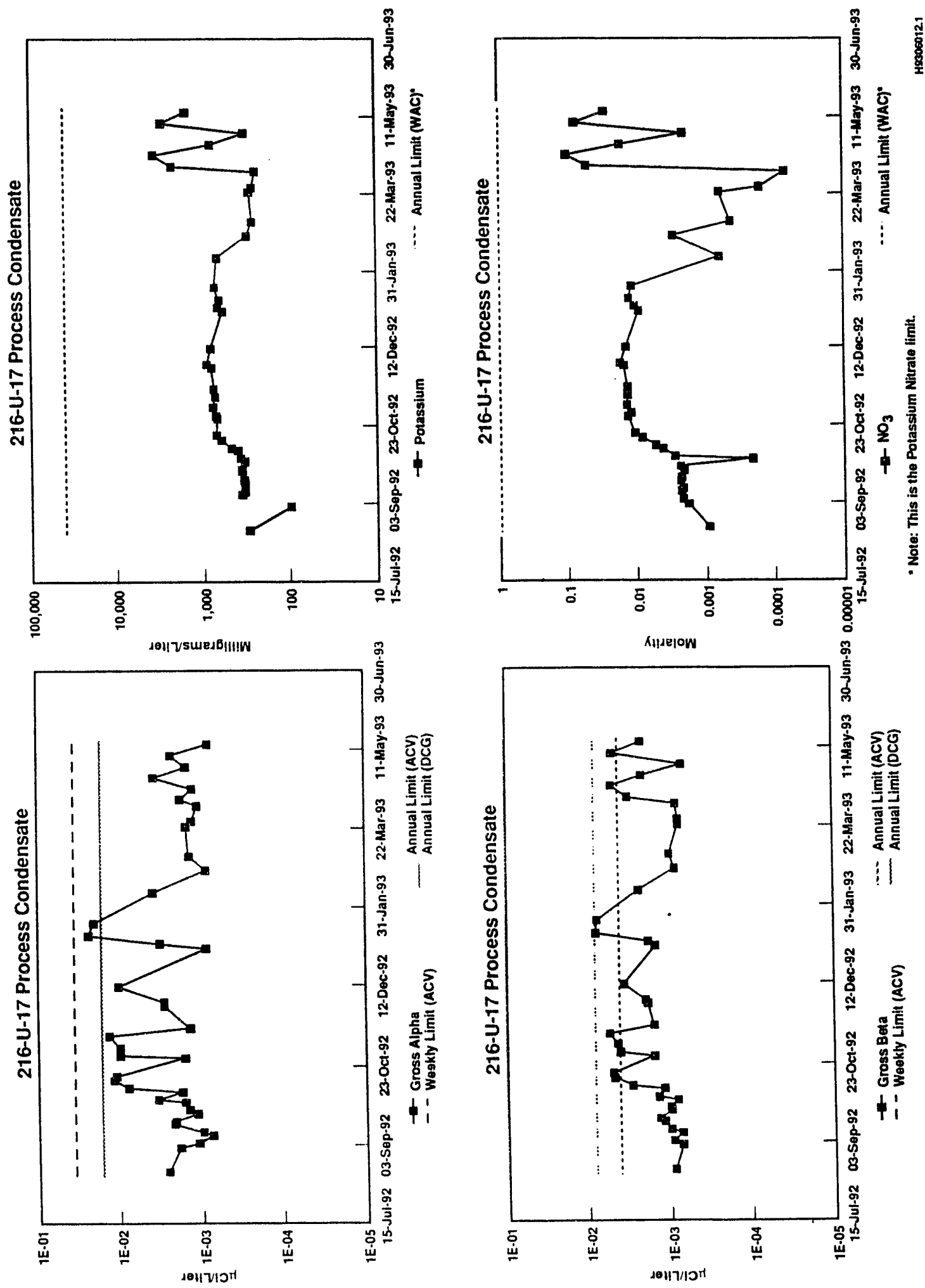
Figure 85. August 1992 - May 1993 Process Condensate Concentrations at 216-U-17 Crib for (A) [upper left] $\mathrm{pH}$, (B) [upper right]

Technetium-99 in $\mu \mathrm{C} i / L$, (C) [lower left] Phosphate Molarity, (D) Uranium in $\mathrm{g} / \mathrm{L}$.
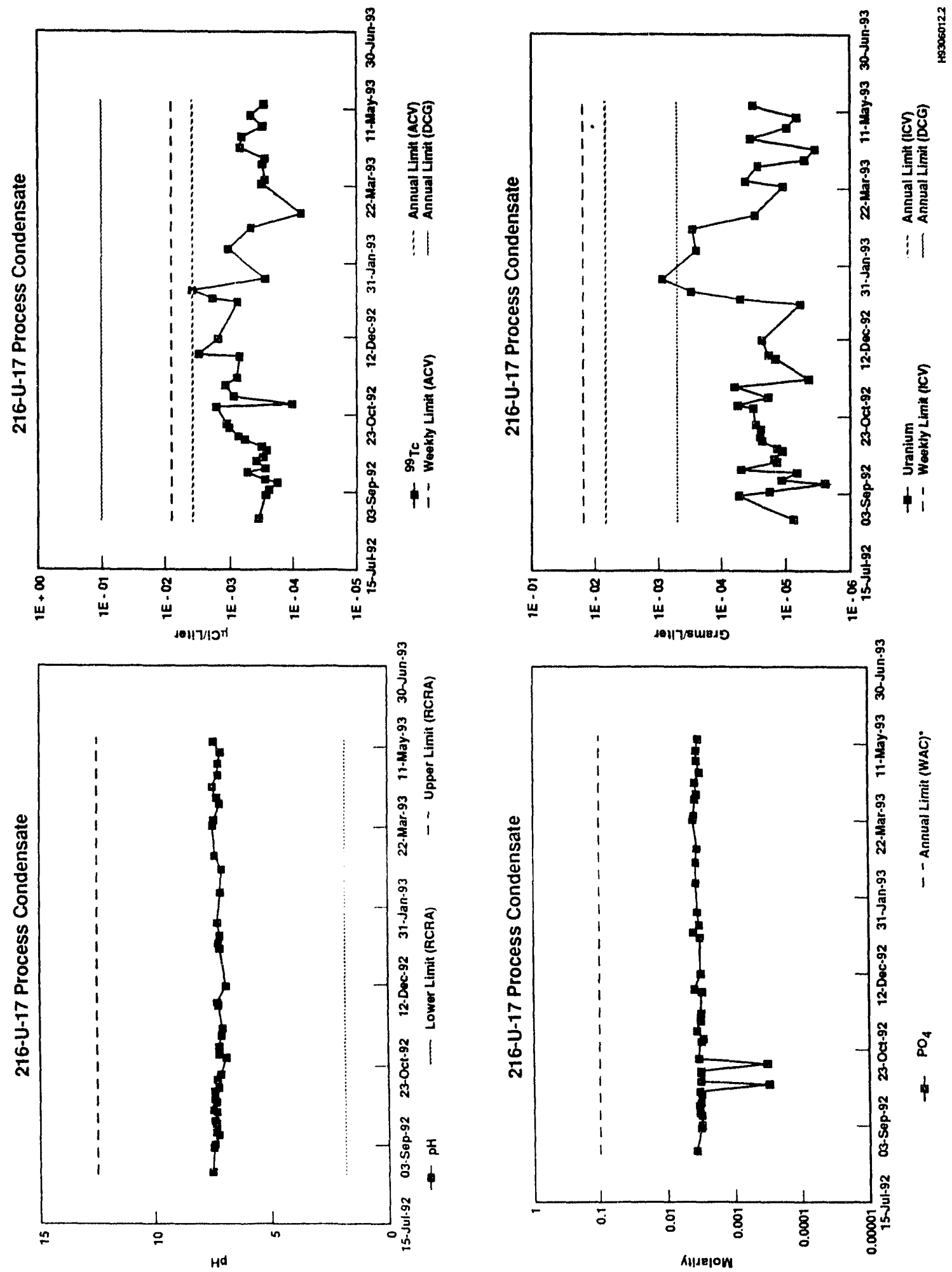
Figure 86. August 1992 - May 1993 Process Condensate Concentrations at 216-U-17 Crib for (A) [upper left] Chromium in mg/L,

(B) [upper right] Fluoride Molarity, and (C) Tritium in $\mu \mathrm{Ci} / \mathrm{L}$.
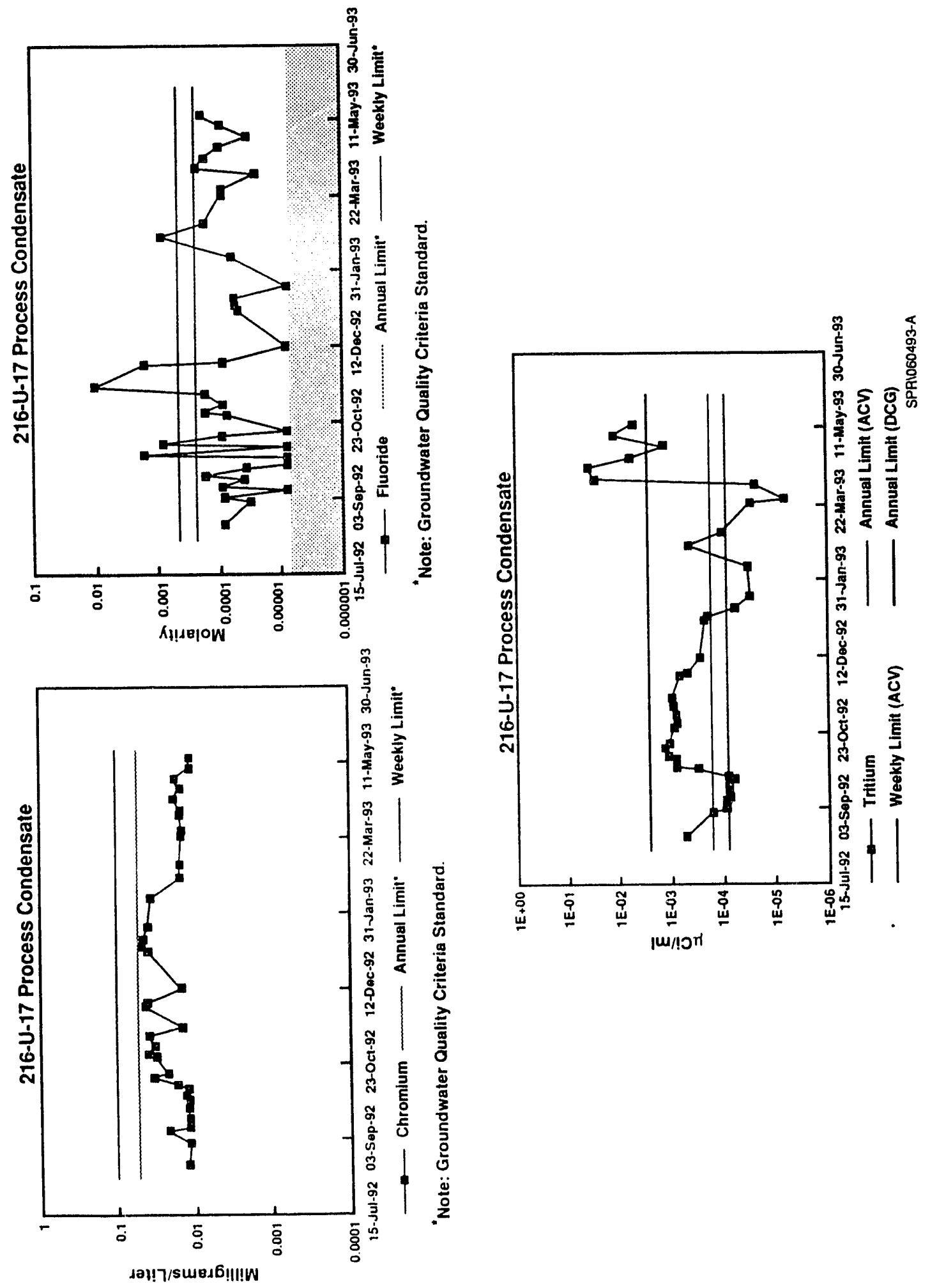
Inclusion of a modest amount of retardation for uranium $\left(K_{d}=1\right)$ results in significantly delayed arrival times at the water table (first arrival in about 500 years). In addition, most of the uranium is held in the soil column.

\subsection{ADEQUACY OF MONITORING WELLS}

Under the current and projected discharge volumes at the $216-U-17 \mathrm{Crib}$, contaminant migration to the water table is not expected for at least several years, if at al1. Existing groundwater monitoring wells at the site (see Figure 2) are considered adequate (Ledgerwood 1993). The Radionuclide Logging System (Appendix B) confirms that there have been no radionuclides moving preferentially down along the borehole annular seal. However, enhanced vadose zone monitoring to evaluate the extent of lateral spreading and reduced vertical movement, as predicted by the simulation effort, may be appropriate.

\subsection{IMPLICATIONS}

The numerical simulations show the importance of natural recharge after disposal of effluent to the crib ceases in 1995. Natural recharge becomes the driving force for contaminants reaching the groundwater. Prior and subsequent to remediation activities, installation of a permanent cover or barrier over the crib and restoration of the surrounding vegetation could limit net infiltration to the very low natural rates ( $<1 \mathrm{~mm} / \mathrm{yr}$ ) that have apparently prevailed on the 200 West Area Plateau for undisturbed ground cover (Murphy et a1. 1991). A cover and/or surface reclamation could be an effective means of stabilizing vadose zone contaminants beneath the crib. 
WHC-EP-0664

This page intentionally left blank. 


\subsection{CONCLUSIONS}

No significant additional impacts on groundwater quality are expected due to the continued use of the 216-U-17 Crib until 1995. The primary impact of effluent disposal will be localized contamination within approximately the upper $30 \mathrm{~m}$ of the soil column beneath the $216-\mathrm{U}-17 \mathrm{Crib}$ id 1995 . The groundwater beneath the 216-U-17 Crib has already been significantly contaminated by upgradient operations. So il contaminants include uranium, technetium, nitrate, fluoride, chromium, and tritium. The spread of contaminants in the soil can be reduced by installing a permanent cover or barrier over the crib, and restoring surrounaing vegetation (Routsen and Johnson 1990). This action would limit net infiltration to the very low rates that prevailed in the 200 West Area in the past, and further reduce downward movement of contaminants in the soil column. 
WHC-EP-0664

This page intentionally left blank. 


\subsection{REFERENCES}

Ames, L. L., and R. J. Serne, 1991, Compilation of Data to Estimate Groundwater Migration Potential for Constituents in Active Liquid Discharges at the Hanford Site, PNL-7660, Pacific Northwest Laboratory, Richland, Washington.

Bear, J., C. Braester, and P. C. Menier, 1987, "Effective and Relative Permeabilities of Anisotropic Porous Media," Transport in Porous Media, 2, pp. 301-316.

Connelly, M. P., J. D. Davis, and P. D. Rittmann, 1991, Numerical Simulation of Strontium-90 Transport from the 100-N Area Liquid Waste Disposal

Facility, WHC-SD-ER-TA-001, Rev. 0, Westinghouse Hanford Company, Richland, Washington.

Connelly, M. P., B. H. Ford, J. W. Lindberg, S. J. Trent, C. D. Delaney, and J. V. Borghese (PNL), 1992a, Hydrogeologic Model for the 200 East Groundwater Aggregate Area, WHC-SD-EN-TI-019, Rev. 0, Westinghouse Hanford Company, Richland, Washington.

Connelly, M. P., B. N. Bjornstad, B. H. Ford, S. J. Trent, and C. D. Wittreich, 1992b, Hydrogeologic Model for the 200 West Groundwater Aggregate Area, WHC-SD-EN-TI-014, Rev. 0, Westinghouse Hanford Company, Richland, Washington.

Delaney, C. D., K. A. Lindsey, and S. P. Reidel, 1991, Geology and Hydrology of the Hanford Site: A Standardized Test for Use in Westinghouse Hanford Documents and Reports, WHC-SD-TI-003, Westinghouse Hanford Company, Richland, Washington.

DOE, 1987, Final Environmental Impact Statement, Disposal of Hanford Defense High-level, Transuranic and Tank Waste, Hanford Site, Richland, Washington, DOE/EIS-0113, U.S. Department of Energy, Richland Operations Office, Richland, Washington.

DOE, 1988, Consultation Draft, Site Characterization Plan, Reference Repository Location, Hanford Site, Washington, DOE/RW-0164, Vols. 1-9, U.S. Department of Energy, Office of Civilian Radioactive Waste Management, Washington, D.C.

DOE-RL, 1991, Expedited Response Action Proposal (EE/CA \& EA) for 200 West Area Carbon Tetrachloride Plume, DOE/RL 91-32, U.S. Department of Energy, Richland Field Office, Richland, Washington.

DOE-RL, 1992, 200 West Area Groundwater Aggregate Area Management Study Report, DOE/RL 92-16, U.S. Department of Energy, Richland Field Office, Richland, Washington.

Ecology, EPA, and DOE, 1990, Hanford Federal Facility Agreement and Consent Order, Washington State Department of Ecology, U.S. Environmental Protection Agency, and U.S. Department of Energy, 0lympia, Washington. 
Freeze, R. A., and J. A. Cherry, 1979, Groundwater, Prentice-Hall, Inc., Englewood Cliffs, New Jersey.

Gee, G. W., 1987, Recharge at the Hanford Site - Status Report, PNL-6403, Pacific Northwest Laboratory, Richland, Washington.

Gephart, R. E., R. C. Arnett, R. G. Baca, L. S. Leonhard, and F. A. Spane, Jr., 1979, Hydrologic Studies Within the Columbia Plateau, Washington: An Integration of Current Knowledge, RHO-BWI-ST-5, Rockweil 1 Hanford Operations, Richland, Washington.

Graham, M. J., M. D. Hal1, S. R. Strait, and W. R. Brown, 1981, Hydrology of the Separations Area, RHO-ST-42, Rockwell Hanford Operations,

Richland, Washington.

Graham, M. J., G. V. Last, and K. R. Fecht, 1984, An Assessment of Aquifer Intercommunication in the $B$ Pond-Gable Mountain Pond Area of the Hanford site, RHO-RE-ST-12-P, Rockwe 11 Hanford Operations, Richland, Washington.

Johnson, V. G., 1993, Westinghouse Hanford Company Operational Groundwater Status Report, WHC-EP-0595, Westinghouse Hanford Company, Richl and, Washington.

Khaleel, R., and T. LeGore, 1990, Effects of Varying Recharge on Radionuclide Flux Rates to the Water Table at a Low-Level Solid Waste Burial Site, WHC-SA-0699-FP, Westinghouse Hanford Company, Richland, Washington.

Last, G. V., S. P. Airhart, M. P. Bergeron, B. N. Bjornstad, M. A. Chamness, C. S. Cline, D. R. Newcomer, J. A. Schranke, D. W. Wallace, and J. S. Wilbur, 1989, Hydrogeology for the 200 Areas Low-Level Burial Grounds--An Interim Report, PNL-6820, Pacific Northwest Laboratory, Richland, Washington.

Ledgerwood, R. K., 1993, Summaries of Well Construction Data and Field Observations for Existing 200 West Resource Protection We $71 \mathrm{~s}$, WHC-SD-ER-TI-005, Westinghouse Hanford Company, Richland, Washington.

Lindsey, K. A., 1991, Revised Stratigraphy for the Ringold Formation, Hanford Site, South-central Washington, WHC-SD-EN-EE-004, Westinghouse Hanford Company, Richland, Washington.

Lindsey, K. A., B. N. Bjornstad, and M. P. Connelly, 1991, Geologic Setting of the 200 West Area: An Update, WHC-SD-EN-TI-008, Rev. 0, Westinghouse Hanford Company, Richland, Washington.

McCord, J. T., D. B. Stephens, and J. L. Wilson, 1991, "Hysteresis and StateDependent Anisotropy in Modelling Unsaturated Hillslope Hydrologic Processes," Water Resources Research, Vol. 27, No. 7, pp. 1501-1518.

Mualem, Y., 1976, "A New Model for Predicting the Hydraulic Conductivity of Unsaturated Porous Media," Water Resources Research, Vol. 12, No. 3, pp. 513-522.

Mualem, Y., 1984, "Anisotropy of Unsaturated Soils," Soil Sci. Soc. Am. J., Vol. $48, \mathrm{pp} .505-509$. 
Murphy, E. M., J. E. Szescody, and S. J. Phillips, 1991, Moisture Content and Recharge Estimates at the Yakima Barricade Borehole, PNL-SA-20155, Pacific Northwest Laboratory, Richland, Washington.

Myers, C. W., S. M. Price, J. A. Caggiano, M. P. Cochran, W. J. Czimer, N. J. Davidson, R. C. Edwards, K. R. Fecht, G. E. Holmes, M. G. Jones, J. R. Kunk, R. D. Landon, R. K. Ledgerwood, J. T. Lillie, P. E. Long, T. H. Mitchel1, E. H. Price, S. P. Reidel, and A. M. Tallman, 1979, Geologic Studies of the Columbia Plateau: A Status Report, RHO-BWI-ST-4, Rockwell Hanford Operations, Richland, Washington.

Myers, C. W., and S. M. Price, eds. 1981, Subsurface Geology of the Cold Creek Syncline: Rockwell Hanford Operations Report, Rockwell Hanford Operations, Richland, Washington.

Reidel, S. P., and K. R. Fecht, 1981, "Wanapum and Saddle Mountains Basalts of the Cold Creek Syncline Area," C. W. Myers and S. M. Price (eds.), Subsurface Geology of the Cold Creek Syncline, RHO-BWI-ST-14, Rockwell Hanford Operations, Richland, Washington.

Reidel, S. P., and P. R. Hooper, eds., 1989, Volcanism and Tectonism in the Columbia River Flood-Basalt Province: Geological Society of America Special Paper 239, 386 pp., 1 plate.

Rockhold, M. L., M. J. Fayer, and G. W. Gee, 1988, Characterization of Unsaturated Hydraulic Conductivity at the Hanford Site, PNL-6488, Pacific Northwest Laboratory, Richland, Washington.

Routson, R. C., and V. G. Johnson, 1990, "Recharge Estimates for the Hanford Site 200 Area Plateau," Northwest Science, Vol. 64, No. 3, pp. 150-158.

Runchal, A. K., B. Sagar, and N. W. Kline, 1992, PORFLO-3: A Mathematical Model for Fluid Flow, Heat, and Mass Transport in Variably Saturated Geologic Media, Users Manual, Version 1.2, WHC-EP-0385, Westinghouse Hanford Company, Richland, Washington.

Stordeur, R. T., and D. L. Flyckt, 1988, 1988 Annual Status Report of the Plan and Schedule to Discontinue Disposal of Contaminated Liquids into the Soil Column and the Hanford Site, WHC-EP-0196-1, Westinghouse Hanford Company, Richland, Washington.

Tallman, A. M., K. R. Fecht, M. J. Marratt, and G. V. Last, 1979, Geology of the Separations Areas, Hanford Site, South-Central Washington, RHO-ST-23, Rockwell Hanford Operations, Richland, Washington.

Toebe, W. E., D. C. Hedengren, and J. H. E. Rasmussen, 1990, UO Plant Process Condensate Stream-Specific Report, WHC-EP-0342, Addendum 19, Westinghouse Hanford Company, Richland, Washington.

Tyler, D. K., 1991, A Methodology for Assessing Impacts to Groundwater from Disposal of Liquid Effluent to the Soil at the Hanford Site, SD-EN-EV-008, Westinghouse Hanford Company, Richland, Washington. 
van Genuchten, R., 1978, Calculating the Unsaturated Hydraulic Conductivity with a New Closed-Form Analytical Model, Report 78-WR-08, Water Resources Program, Department of Civil Engineering, Princeton University, Princeton, New Jersey.

WAC 173-200, 1990, "Water Quality Standards of the State of Washington," Washington Administrative Code, as amended.

WHC, 1990a, Liquid Effluent Study Final Project Report, WHC-EP-0367, Westinghouse Hanford Company, Richland, Washington.

WHC, 1990b, Environmental Engineering, Technology, and Permitting Function Quality Assurance Program Plan, WHC-EP-0383, Westinghouse Hanford Company, Richland, Washington.

WHC, 1992, Uranium Oxide $\left(\mathrm{UO}_{3}\right)$ Plant Process Condensate Effluent to 216-U-17 Crib Sampling and Analysis Plan, WHC-SD-CP-PLN-011, Westinghouse Hanford Company, Richland, Washington.

Yeh, T., C. Jim, L. W. Gelhar, and A. L. Gutjhar, 1985a, "Stochastic Analysis of Unsaturated Fiow in Heterogeneous Soils, 1. Statistically Isotropic Media," Water Resources Research, Vol. 21, No. 4, pp. 447-456.

Yeh, T., C. Jim, L. W. Gelhar, and A. L. Gutjhar, 1985b, "Stochastic Analysis of Unsaturated Fiow in Heterogeneous Soils, 2. Statistically Anisotropic Media With Variable $\alpha$," Water Resources Research, Vo1. 21, No. 4, pp. 457-464.

Yeh, T., C. Jim, L. W. Gelhar, and A. L. Gutjhar, 1985C, "Stochastic Analysis of Unsaturated Flow in Heterogeneous Soils, 3. Observations and Applications," Water Resources Research, Vol. 21, No. 4, pp. 465-471. 
WHC-EP-0664

APPENDIX A

PROCESS OPERATION

A- $i$ 
WHC-EP-0664

This page intentionally left blank. 


\section{A1.0 PROCESS OPERATION}

\section{A1.1 CALCINATION MODE PROCESS ACTIVITIES}

In calcination mode, virtually all process systems at Uranium Trioxide $\left(\mathrm{UO}_{3}\right) \mathrm{Plant}$ are in continuous operation to convert uranyl nitrate hexahydrate (UNH) from the Plutonium-Uranium Extraction (PUREX) Facility into $\mathrm{UO}_{3}$ powder. other operations performed at $\mathrm{UO}_{3} \mathrm{Pl}$ ant as part of the calcination mode follow:

- Scrubbing of UNH calcination offgas with nitric acid to dissolve entrained $\mathrm{UO}_{3}$, and second-stage acid absorption treatment with process condensates to recover nitric acid for reuse at the PUREX Facility

- Collecting and concentrating various uranium-bearing rinse, flush, and decontamination solutions for shipment to the PUREX Facility and subsequent uranium recovery at that facility

- Handling and disposing gaseous and liquid wastes.

The process, depicted in Section 3.1.1.1, Figure 5 of this document, begins with the transport of UNH from the PUREX Facility. Uranium product, as $60 \%$ UNH $(2.1 \mathrm{M})$, was transported to the $\mathrm{UO}_{3}$ Plant in a $10,599-\mathrm{L}(2,800$-gal) tank trailer. The UNH solution is then pumped to Tank $\mathrm{C}-1$ in $\mathrm{C}-\mathrm{Cell}$. The solution was sampled for accountability and visible organic layer. The UNH accepted for processing is pumped to, and stored in, two $378,540-\mathrm{L}$ $(100,000-\mathrm{ga} 1)$ storage tanks $(X-1$ and $X-2)$ located in the 203-U area.

After sufficient UNH inventory has been accumulated in the storage facilities, the UNH solution is pumped from the 203-U area to concentrators in $\mathrm{D}$-Cell. The solution is concentrated from a uranium content of 2.1 ( $60 \%$ UNH) to $5.5 \mathrm{M}(100 \% \mathrm{UNH})$ by boiling in the concentrators. The concentrated UNH, routed to the 203-UX area, is stored in a steam-heated tank $(X-30)$ to prevent freezing of the concentrated solution.

offgas from each concentrator overheads' knockout pot is routed through a catch tank to the E-D-3 condenser. Water and a small amount of nitric acid vapors given off during concentration are condensed, and comprise, on a volume basis, the largest contributor to the process condensate. A portion of the process condensate is used as reflux water in the acid absorber tower; the balance is neutralized and discarded to the 216-U-17 Crib as waste.

Small quantities of $17 M(93 \%)$ sulfuric acid are injected into the concentrated UNH stored in the 203-UX area.

Concentrated UNH is filtered and pumped to the 224-UA Building where the calcination process is conducted. Conversion of $\mathrm{UNH}^{2}$ to $\mathrm{UO}_{3}$ powder occurs by thermal decomposition in six electrically heated, continuously agitated trough calciners. The UNH feed is supplied to the calciners from a pressurized, electricalily heat-traced recirculation loop.

Before operation, the calciners are filled with $\mathrm{UO}_{3}$ bed powder and the electric furnaces are turned on. The furnaces are operated over a 30-hour 
period to bring the calciner shell temperature to $400{ }^{\circ} \mathrm{C}$. This time period is necessary to minimize warpage of the calciner she11. As the temperature reaches $400^{\circ} \mathrm{C}$, UNH is introduced into the calciners through four feed points. This initial feed introduction reduces the calciner temperature. The UNH feed to the calciner is temperature controlled such that the calciner bed operates at $270{ }^{\circ} \mathrm{C}$, while the shell temperature is incrementally increased to about $500{ }^{\circ} \mathrm{C}$ for optimal processing efficiency.

When UNH contacts the heated bed powder, the conversion to $\mathrm{UO}_{3}$ is almost instantaneous. This $\mathrm{UO}_{3}$ coats the bed powder to form larger spherical particles. The resulting accumulation overflows a weir at one end of the calciner.

The rapid decomposition of UNH in the calciners liberates quantities of water vapor, oxygen, and oxides of nitrogen. This offgas is scrubbed with nitric acid to dissolve $\mathrm{UO}_{3}$ particles and then is routed through a gas cooler and on to an acid absorber tower. Suction vacuum for this system is provided by steam jets on the 224-U roof. As the offgas bubbles rise through bubble cap trays in the tower, nitric acid is formed. This acid is approximately $10.4 \mathrm{M}(60 \%)$. The remaining gas is passed through the E-B-3 condenser before discharge to the environment via the 24-m (80-ft) 296-U-4 Stack. Calciner offgas condensate from the E-B-3 condenser contributes the bulk of the acidity found in the preneutralized process condensate.

The $\mathrm{UO}_{3}$ powder from the calciner falls into a pickup bin. This product is conveyed pneumatically to the powder handling tower where the powder and air are separated by a cyclone separator. The exhaust air from this operation is routed through primary and secondary bag filters, a prefilter, and a highefficiency particulate air filter before discharge to the environment via the 296-U-2 Stack. Powder from the cyclone and primary bag filter is collected in the powder hopper. Powder from the secondary bag filter is collected in $113-L$ (30-gal) drums. There are two parallel trains of cyclones and bag filters; when one is in operation, the other is in standby.

The $\mathrm{UO}_{3}$ in the powder hopper discharges into shipping containers in the powder loadout room. Filled containers, called T-hoppers, contain about 4.6 metric tons of uranium each as $\mathrm{UO}_{3}$, and are stored on a concrete pad in a fenced area north of the 2714-U Building. Powder is shipped offsite from this area via specially equipped railcars. Small amounts of powder from the secondary bag filters are collected in 113-L (30-gal) drums and put back into the powder handling system.

Room air from the loadout enclosure in the loadout room is passed through a prefilter and high-efficiency particulate air filter, then sampled for radioactive particulates and monitored before discharge to the environment via the 296-U-13 Stack.

The Tank $C-2$ recycle concentrator operates, as needed, to concentrate flush solutions, rainwater, and other solutions in the 203-U, 224-UA, backpad, and 224-U cell drain system sumps that potentially contain uranium. Before entering calcination mode, the batch accumulation recycle concentrator is emptied, as needed, to ensure that it will not need to be emptied while in the calcination mode. 
Process condensate resulting from these activities is neutralized and discharged to the 216-U-17 Crib on a batch-continuous basis. The condensate in surge tank $X-37$ is sampled regularly to ensure no entrainment of uranium or technetium is within environmental release limits. Samples are also analyzed for nitrate content to ensure that the nitrate concentration will be below the operating specification limit of 10 weight percent upon discharge.

\section{A1.2 STANDBY MODE PROCESS ACTIVITIES}

During standby, activities are focused on preparing the $\mathrm{UO}_{3} \mathrm{Pl}$ ant for the next calcination mode operation. Equipment is flushed, decontaminated, and repaired. The Tank $\mathrm{C}-2$ recycle concentrator operates, as needed, to concentrate flush solutions, rainwater, and other solutions in the 203-U, 224-UA, backpad, and 224-U cell drain system sumps that potentially contain uranium. The contents of the recycle concentrator are filtered and stored in Tank $X-38$ for shipment to the PUREX Facility during standby when necessary to ensure adequate concentrator capacity during calcination mode. Recovered nitric acid is shipped to the PUREX Facility when needed at that facility. The UNH feed solution is shipped from the PUREX Facility to $\mathrm{UO}_{3}$ Plant, as available, in preparation for the next calcination mode operating period.

Process condensate resulting from standby mode activities accumulates in the $\mathrm{X}-37$ surge tank, and is neutralized and discharged to the 216-U-17 $\mathrm{Crib}$ after sampling. Process condensate generation rates during standby mode are low enough that the accumulated preneutralized solution can be quarantined in the $x-37$ tank for sampling before neutralization and discharge to the crib. Samples are analyzed for uranium, technetium, and nitrate, to ensure that any entrainment from the recycle concentrator is within environmental release limits. The following two sections address neutralization, sampling, and monitoring of process condensate.

\section{A1.2.1 Process Condensate Neutralization}

The present $\mathrm{UO}_{3} \mathrm{Plant}$ process condensate neutralization system has successfully neutralized all process condensates discharged to the 216-U-17 Crib (Toebe et al. 1990). The few process condensate neutralization system upsets to date have resulted in locking up the system, in accordance with built-in fail-safe features to prevent discharge to the crib. The $52,996-L(14,000-g a l) X-37$ surge tank allows for neutralization system maintenance and calibration outages.

The process condensate neutralization system is an automatic batch elementary neutralization process. Level interlocks automatically control the transfer pump from surge Tank $X-37$ to neutralization Tank $C-5$. A predetermined dose of phosphoric acid is pumped from Tank $C-8$ to Tank $C-5$ every time condensate is pumped from Tank $X-37$ to DK-C-5. Tank $C-5$ is equipped with a pumped recirculation loop and a mechanical agitator. Potassium hydroxide from Tank $\mathrm{X}-36$ is added to the pumped recirculation loop under $\mathrm{pH}$ feedback control. When two independent $\mathrm{pH}$ sensors agree that Tank $\mathrm{C}-5$ has stabilized within the target $\mathrm{pH} 6.5$ to 8.5 range, the pumped recirculation loop is diverted to the 216-U-17 Crib; any deviation of the pH outside of normal range will terminate the transfer. Additionally, an administrative control is provided that will trigger a neutralization incomplete alarm if the neutralization process takes longer than a predetermined length of time that is established by the capacity 
of the metering pumps and the expected maximum initial acidity. Significantly higher incoming condensate acidity would take much longer to neutralize, triggering this alarm and a subsequent investigation as to the cause.

Many redundant and fail-safe features have been provided to prevent discharges from Tank $\mathrm{C}-5$ to the $216-\mathrm{U}-17$ Crib outside the target $\mathrm{pH}$ range. For example, the pumped recirculation loop is isolated from the crib by double-block-and-bleed valving. Caustic addition and batch discharge are only permitted when the agitator and pumped recirculation loop are operating to ensure uniform mixing and representative $\mathrm{pH}$ readings. The pumped recirculation loop shuts down and the valves revert to their fail-safe double-block-and bleed positions upon loss of electrical power. The configuration of the discharge 1 ine to the $216-\mathrm{U}-17 \mathrm{Crib}$ does not permit gravity drainage from Tank C-5 to the crib if the pumps fail.

\section{A1.2.2 Process Condensate Sampling and Monitoring}

An automatic batch proportional composite sampler and redundant $\mathrm{pH}$ probes have been installed downstream of the neutralization system in $\mathrm{A}-\mathrm{Ce} 11$ to monitor the effluent to the 216-U-17 Crib immediately before exiting the 224-U Building. The A-Cell location was chosen for two reasons. First, A-Cel1 is downstream of any contributors to the process condensate 1 ine to the $216-U-17$ Crib to ensure that samples are representative of what is actually sent to the disposal site. Secondly, A-Cell is a convenient, readily accessible indoor location protected from adverse weather conditions.

Each of the two A-Cell pH probes is connected to a separate transmitter, alarm switch, and stripchart recorder to ensure redundancy in case of singlecomponent equipment failure. An alarm sounds in the 224-U Control Room if either of the A-Cell pH monitors is outside the expected 6.5 to $9 \mathrm{pH}$ system and the A-Cell monitoring system. The A-Cell pH monitors perform no control functions.

The A-Cell pH instruments are calibrated monthly with $\mathrm{pH} 2,4,7,10$, and 12 buffer solutions to span the $\mathrm{pH}$ range of interest. The recorders are capable of displaying $\mathrm{pH}$ over the entire 0 to $14 \mathrm{pH}$ range.

The Isolok' Model SAB automatic sampler is controlled by the Tank C-5 discharge interlocks. The automatic sampler is located in A-Cell just upstream of the record $\mathrm{pH}$ probes. Samples are obtained whenever condensate is being transferred to the 216-7-17 crib. The resulting composite batch sample is flow proportional. Each Tank C-5 batci is well mixed; the Tank C-5 batch discharge volumes are consistent; and the sampler obtains the same sample volume from each batch.

Flow monitoring for the $\mathrm{UO}_{3} \mathrm{Plant}$ process condensate consists of a digital batch counter. The batch volume is multiplied by the batch counter reading to determine the total discharge volume. Each batch discharge is also documented on Tank $C-5$ and Tank $X-37$ level charts.

${ }^{1}$ Isolok is a trademark of Bristol Engineering Company, Yorkville, Illinois. 


\section{A1.3 REFERENCE}

Toebe, W. E., D. C. Hedengren, and J. H. E. Rasmussen, 1990, UO 3 Plant Process Condensate Stream-Specific Report, WHC-EP-0342, Addendum 19, Westinghouse Hanford Company, Richland, Washington. 
WHC-EP-0664

This page intentionally left blank. 
WHC-EP-0664

APPENDIX B

RADIONUCLIDE LOGGING SYSTEM PASSIVE SPECTRAL GAMMA RAY BOREHOLE SURVEY REPORT

$B-\mathbf{i}$ 
WHC-EP-0664

This page intentionally left blank.

$B-i j$ 
RLS Passive Spectral Gamma-Ray Borehole Survey Report

Report Date:

Project:

Boreholes:

Calibration Date:

Logging Engineers:

Analyst:
May 19, 1993

216-U-17 Crib

299-W19-19

299-W19-20

299-W19-25

299-W19-26

299-W19-89

299-W19-90

November 1991

R. V. Cram,

W. F. Nicaise,
Date:

$1 / 25 / 93$
$5 / 04 / 93$
$5 / 07 / 93$
$3 / 17 / 93$
$12 / 30 / 92$
$12 / 22 / 92$

Max Depth: 245'

$245^{\prime}$

$245^{\prime}$

$245^{\prime}$

$150^{\prime}$

$156^{\prime}$

S. E. Kos

R. K. Price

\section{Introduction}

Logging with the high resolution, high purity germanium (HPGe) passive spectral gamma-ray system has been completed for the six boreholes along the 216-U-17 crib. The borehole numbers, survey date and maximum survey depth are tabulated above.

The object of the Radionuclide Logging System (RLS) surveys was to detect the presence of low levels of man-made radionuclides that may have been released to the crib. No gamma-ray emitting man-made radionuclides were identified in these boreholes. The graphs of the decay activities (concentrations) versus depth for the natural radionuclides, potassium, uranium, and thorium, (KUT) are presented for each survey. Decay activities are reported in pico-curies per gram $(\mathrm{pCi} / \mathrm{g})$ of sample. The surveys were acquired at 150 -seconds per depth interval along the full borehole length, instead of the normal 80seconds per depth interval. The increased counting time reduces the minimum detection level to about $0.2 \mathrm{pCi} / \mathrm{g}$ for cobalt-60.

The contents of the report are limited to the description of the survey results for each borehole logged. Details of the equipment configuration, calibration, logging procedures, casing and water correction factors, spectra analysis software, and data management have been excluded. The details of the excluded topics are described in the papers cited at the end of this report.

\section{6-U-17 Crib Borehole Geophysics Project Review}

Observations of the RLS borehole surveys included in this report are summarized below. This review does not necessarily include all the information that can be gleaned from the spectral gamma-ray survey data.

BENTONITE HOLE SEAL: The survey of boreholes 299-W19-19, 299-W19-25 and 299-W19-26 recorded a cyclical Total Gamma activity from about 15 to 120 feet. Within this depth range the potassium concentrations appear to alias the Total Gamma count rates. Each cycle includes a short depth interval containing higher Total Gamma activity, the corresponding potassium decreases from about $20 \mathrm{pCi} / \mathrm{g}$ to less than $10 \mathrm{pCi} / \mathrm{g}$ in some cycles. Further investigation of the 
cyclic character of the survey reveal that uranium and thorium increase in unison with the Total Gamma summary curve.

The cyclic character of the log survey is explained as follows. These boreholes contain a granular bentonite as the sealing material between the stainless steel casing and the formation. The procedure used during completion of these wells permitted inconsistent placement of the sealing material around the casing as the construction casing was being removed. The spectral gamma-ray borehole survey identifies these intervals with good bentonite seal as containing lower than normal potassium and higher than normal Total Gamma, uranium and thorium. The intervals with the lower Total Gamma activity also represent normal concentrations of potassium, uranium and thorium. The lower Total Gamma depth intervals identify places where the bentonite sealing material is not uniform and may have been displaced by movement of the unconsolidated formation materials.

EQUIPMENT CALIBRATION: The borehole surveys presented in this report have all been analyzed using the calibration data acquired in November 1991.

Calculation of the calibration factors used in data reduction depended on the calibration data and on nuclear data (half-lives, branching ratios, number of gammas per decay) for the particular nuclide. All of the nuclear data were taken from Erdtmann and Soyka, Die Gamma-Linien der Radionuklide (The Gamma Rays of the Radionuclides), Verlag Chemie GMBh Weinheim, Deutchland, 1979.

\section{Borehole Survey Report}

The report for each borehole survey by the RLS contains three types of information. The contents of each information type are described below. The borehole survey reports are presented in the same order as they are listed above.

1. A single page log header form is first. The form is titled "RLS Spectral Gamma-Ray Borehole Survey Log Header" and summarizes the borehole and survey information.

The form contains the borehole name, coordinates, and elevation.

Borehole environment information is next and includes casing parameters and water depth (if present). These are the parameters used for data reduction.

RLS survey information is presented third and includes the logging engineers name, date, file names, logging mode, and survey depths.

The survey data reduction information follows and includes calibration date and calibration report number, analyst names and analysis date. A single 1 ine is present for analysis notes and man-made radionuclides encountered.

2. Radionuclide activity responses versus depth, i.e., data plots, are plotted on one or more pages. A uniform depth scale of 20 feet/inch is used for all plots. The experimental uncertainties in the computed radionuclide activities are not presented on the data plots at this time. 
The "Total Gamma" is the count rate for all gamma-rays detected by the RLS detector with no discrimination of gamma-ray energy. The "Total Gamma" is equivalent to the gross gamma log commonly used by some organizations at Hanford. The count rate data values are plotted on the scale of 0 to $500 \mathrm{c} / \mathrm{s}$. The natural radionuclides (potassium, uranium and thorium) are plotted in the three remaining tracks.

3. The analysis notes follow as the third type of information reported for each spectral gamma-ray survey. The notes contain descriptions of the borehole conditions and possible.limitations of the plotted results. The depth ranges where each man-made radionuclide was encountered and the maximum activities are reported.

\section{Limitations to the Radioelement Analyses}

Several limitations of the borehole survey equipment, calibration, and data acquisition objectives follow.

The logging cable supporting the borehole detector, supplying electrical power, receiving voltage signals for each detected gamma-ray, and permitting the liquid-nitrogen cooled detector to be submerged in water was specially fabricated for the RLS system. The recorded depth of the detector is estimated to be accurate to 98.5 percent, with a precision (repeatability) of 99 percent. Comparisons with drilling measurements, other logging equipment, and secondary measuring systems have verified the accuracy. An upgrade in the logging cable and measuring system is being investigated.

The standard logging configuration optimizes the counting system for detecting low decay activities of radioeleme

rkp

Attachment 
RLS Passive Spectral Gamma-Ray Borehole Survey Report

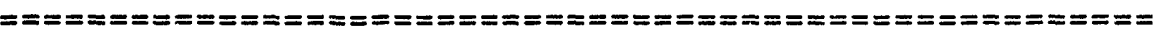

Report Date:

Project:

Boreholes:
May 19,1993

216-U-17 Crib

$299-W 19-19$
$299-W 19-20$
$299-W 19-25$
$299-W 19-26$
$299-W 19-89$

Date:

$1 / 25 / 93$
$5 / 04 / 93$
$5 / 07 / 93$
$3 / 17 / 93$
$12 / 30 / 9 n t s$.

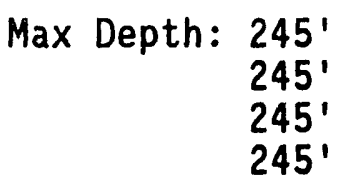
detected man-made radioelement activities of $0.3 \mathrm{pCi} / \mathrm{g}$ for nuclides with gamma-rays having energies greater than $500 \mathrm{keV}$ and number of gammas per decay at greater than 50 percent. The maximum decay activity the RLS has detected is about $10,000 \mathrm{pCi} / \mathrm{g}$ in this standard configuration.

Borehole environment correction factors have been determined for steel casing and water in the borehole. Correction factors for other borehole configurations have not been investigated. Borehole configurations for which no correction is available include: (1) grout between multiple casing strings, (2) formation seals containing bentonite, sand, or grout behind the casing, and (3) drilling mud remaining inside the borehole during logging. The calculated decay activity for manmade radionuclides will be underestimated for boreholes with these configurations.

Energy dependent casing corrections have been established for steel casing thicknesses up to 0.40 inches. Corrections for casings of different materials and/or cumulative thicknesses greater than 0.40 inches have not been calculated and therefore cannot be used in the data reduction.

The calibration data were recorded with the detector centered in calibration zones that are uniform in density, water content, and gamma-ray source material. The dimensions of each zone are large enough that the detector always responded as though surrounded by a medium of infinite extent. Therefore, the use of the calibration results to calculate nuclide activity carries the assumption that the nuclides in the logged formation are also distributed in thick uniform layers.

Gamma-ray sources are not normally distributed in the earth in thick uniform layers. Source inhomogeneities are reflected to some degree by the fluctuations in the amplitudes of the log traces. A factor.called the vertical spacial resolution quantifies the correlation between (1) the intensity of the log fluctuation and the depth interval over which it extends, and (2) the intensity of the corresponding gamma-ray source and the thickness of the zone in which the source is embedded. The vertical spatial resolution of the RLS HPGe logging system is scheduled for investigation.

Radionuclide decay activities are determined from the net area of the gammaray peaks. Radioelements such as strontium-90 which do not emit a gamma-ray when they decay will not be identified or quantified by the spectra analysis performed for this report. The decay of strontium-90 results in a high energy beta particle that can excite surrounding elements to emit photon radiation that can be identified by the HPGe detector. This type of radiation is called bremsstrahlung radiation. A method to obtain estimates of the concentrations of strontium-90 is under consideration. 


\section{Conclusion}

The RLS has completed surveys for six boreholes associated with 216-U-17 Crib. No man-made gamma-ray emitting radionuclides were identified in any borehole. The borehole survey specifications were increased from the standard 80 -seconds per depth interval to 150-seconds. This improved the minimum detection level for radionuclides like cobalt-60 to about $0.2 \mathrm{pCi} / \mathrm{g}$.

The decay activity for the natural radionuclides, KUT, have been computed by the data reduction program and were presented in this report.

\section{Cited Reports}

Koizumi, C. J., J. R. Brodeur, W. H. UTbricht, and R. K. Price, 1991, "Calibration of the RLS HPGe Spectral Gamma-Ray Logging System," WHC external publication WHC-EP-0464

Brodeur, J. R., C. J. Koizumi, W. H. Ulbricht, and R. K. Price, 1991, "Calibration of a High-Resolution Passive Gamma-Ray Logging System for Nuclear Waste Assessment," WHC Speech Article Report WHC-SA-1175-FP

Koizumi, C. J., R. K. Price, and R. D. Wilson, 1992, "Calibration of the RLS System for 200 Aggregate Area Management Study Screening Measurements," WHC supporting document WHC-SD-EN-TRP-001

Brodeur, J. R, C. J. Koizumi, R. K. Price, and R. D. Wilson, 1992, "Gamma-Ray Logging results for the 200 Aggregate Area Management Study," WHC supporting document WHC-SD-EN-TI-021 
WHC-EP-0664

This page intentionally left blank.

B-6 
RLS Spectral Gamma-Ray Borehole Survey

Project: U 17 Crib

Borehole: 299-W19-19
Log Date : Jan 25, 1993

Anal Date: Apr 05, 1993

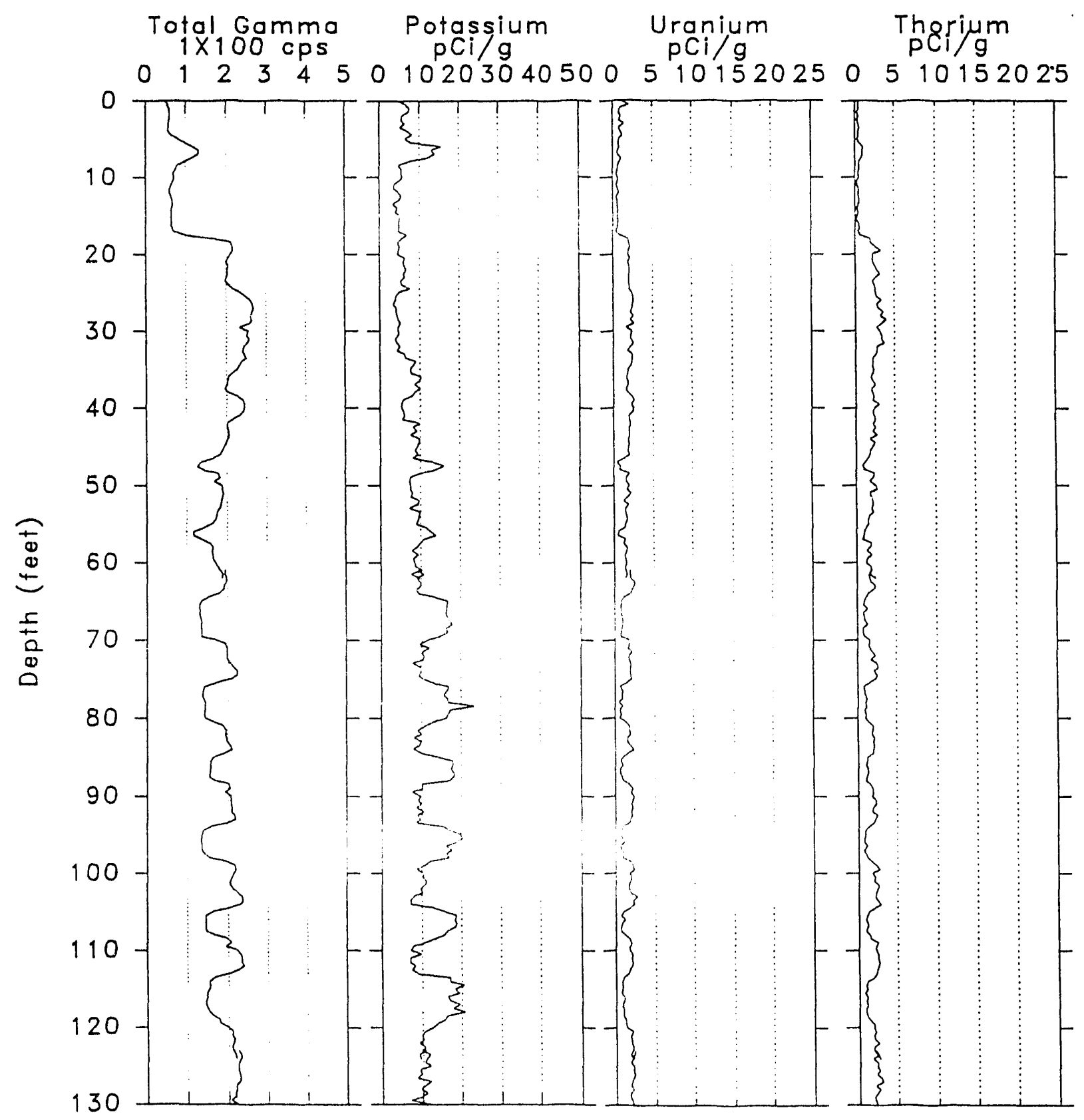


RLS Spectral Gamma-Ray Borehole Survey

Project: $U 17$ Crib

Borehole : 299-W19-19
Log Date : Jan 25, 1993

Anal Date: Apr 05, 1993

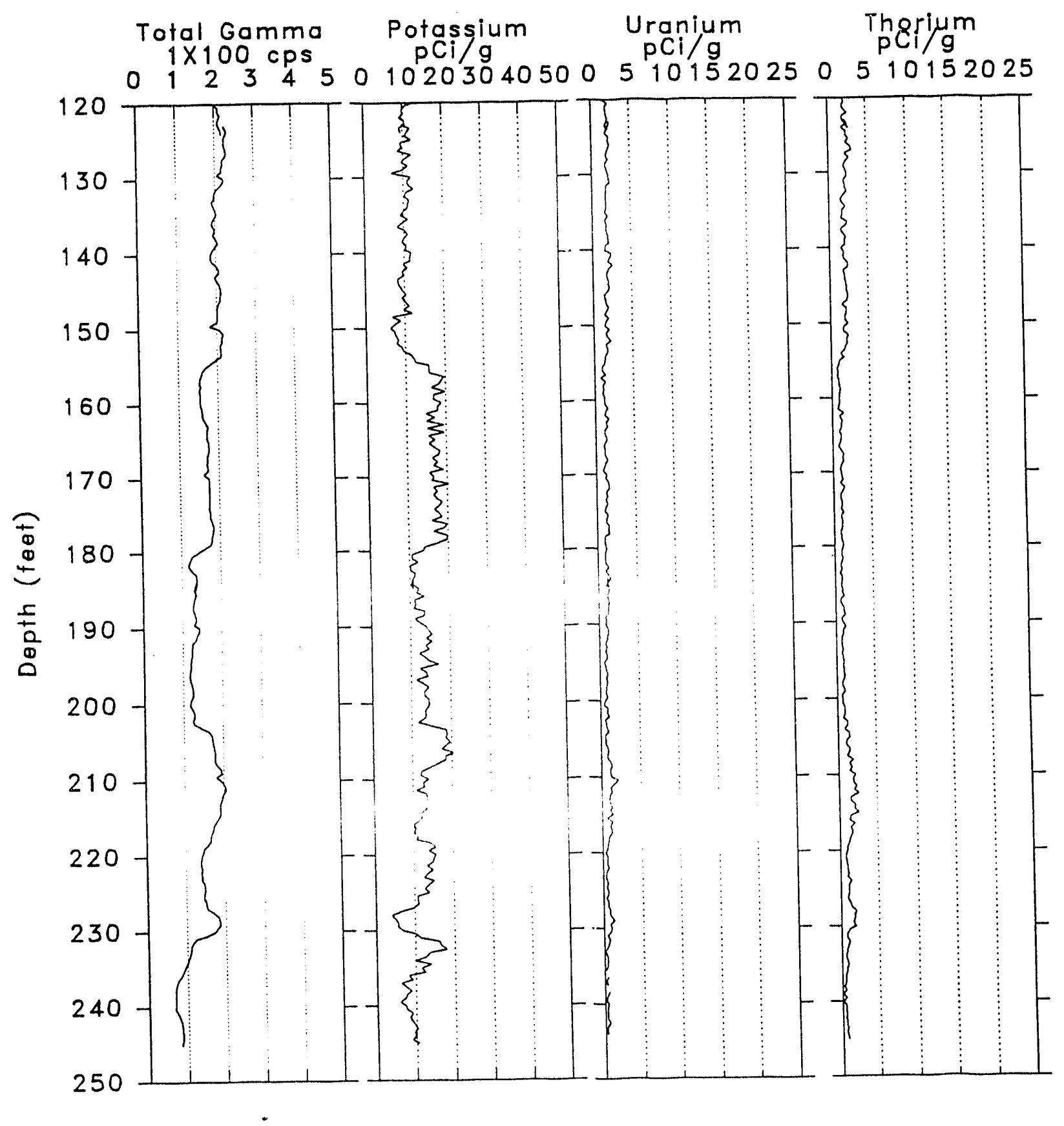


RLS Spectral Gamma-Ray Borehole Survey

Project: U-17 Crib

Borehole : 299-W19-20
Log Date: May 04, 1993

Anal Date: May 18, 1993

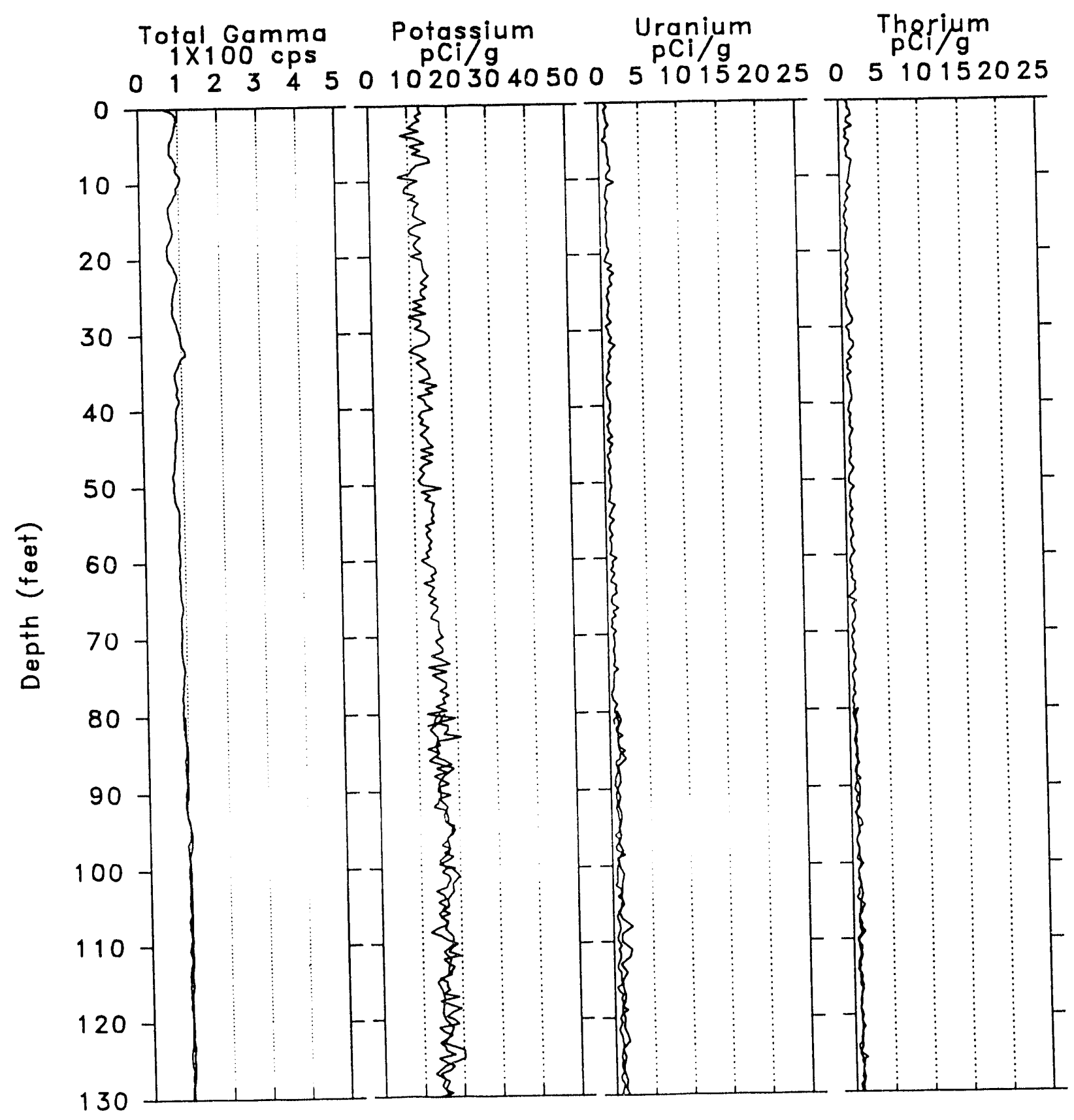


RLS Spectral Gamma-Ray Borehole Survey

Project: U? 17 Crib

Borehole : 299-W19-20
Log Date : May 04, 1993 Anal Date: May 18, 1993

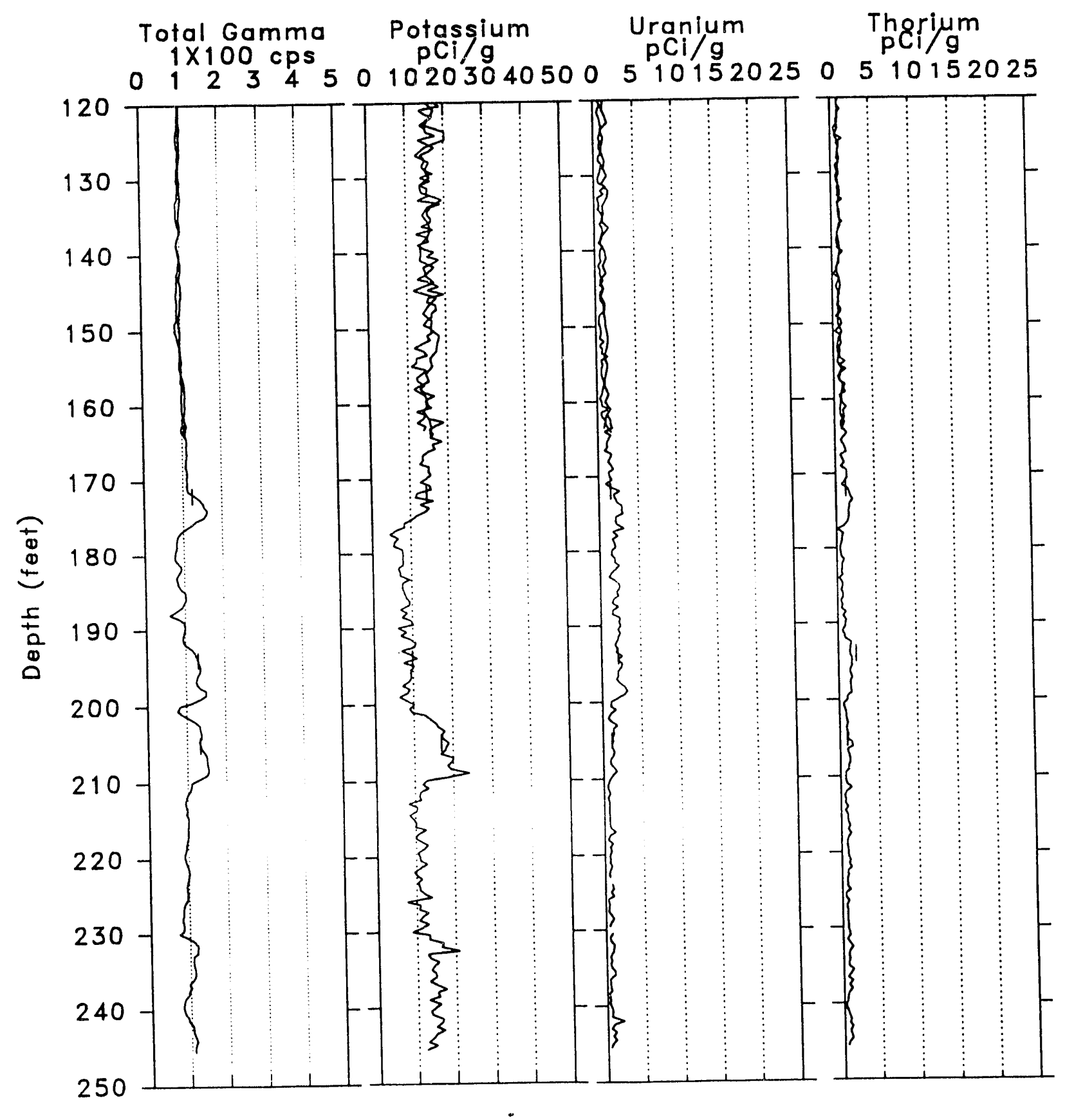


RLS Spectral Gamma-Ray Borehole Survey

Project: U-17 Crib Logging

Borehole : 299-W19-25
Log Date: May 07, 1993

Anal Date: May 18, 1993

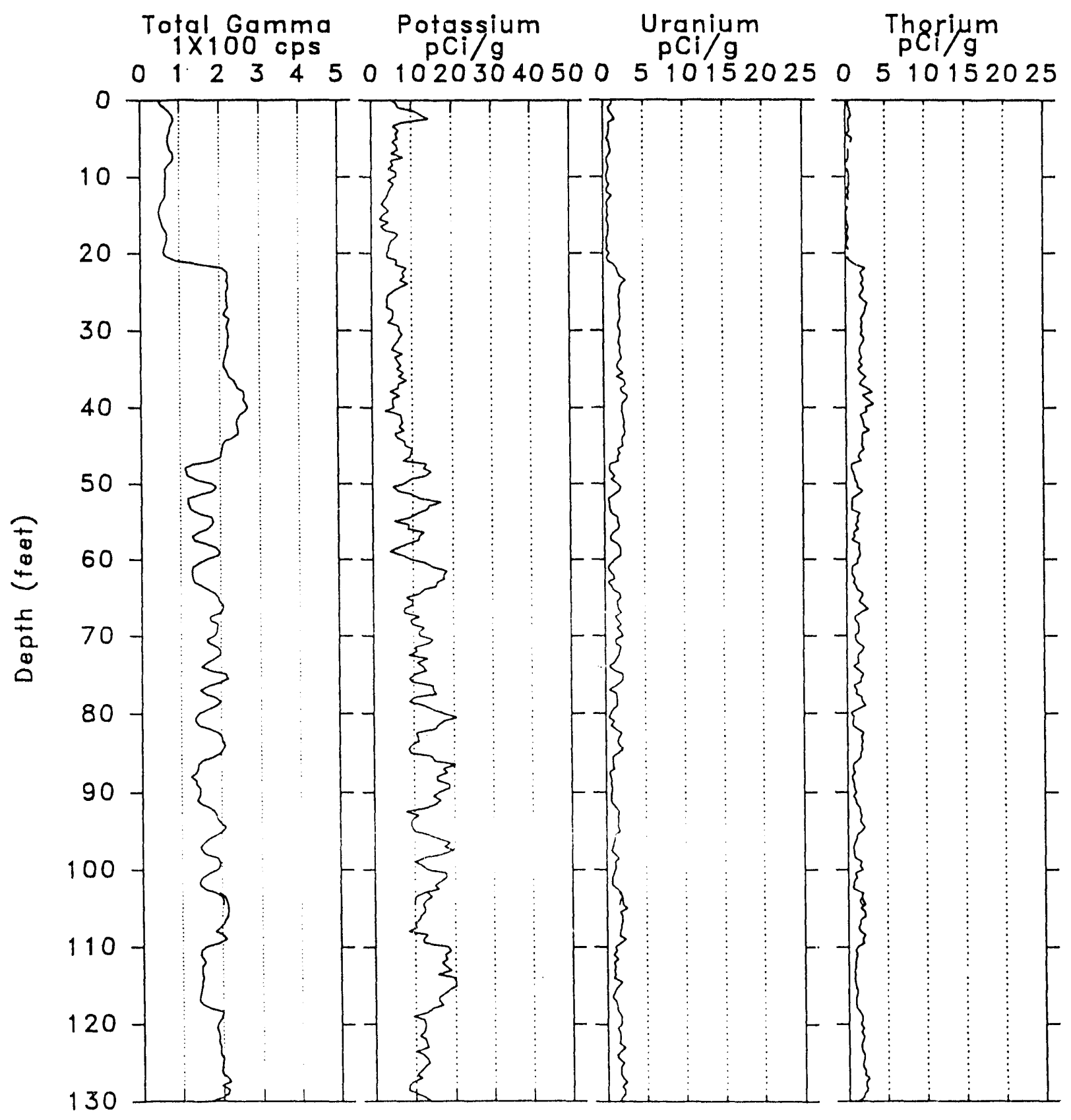


RLS Spectral Gamma-Ray Borehole Survey Project: $U-17$ Crib Logging Borehole: 299-W19-25

Log Date: May 07, 1993 Anal Date: May 18, 1993

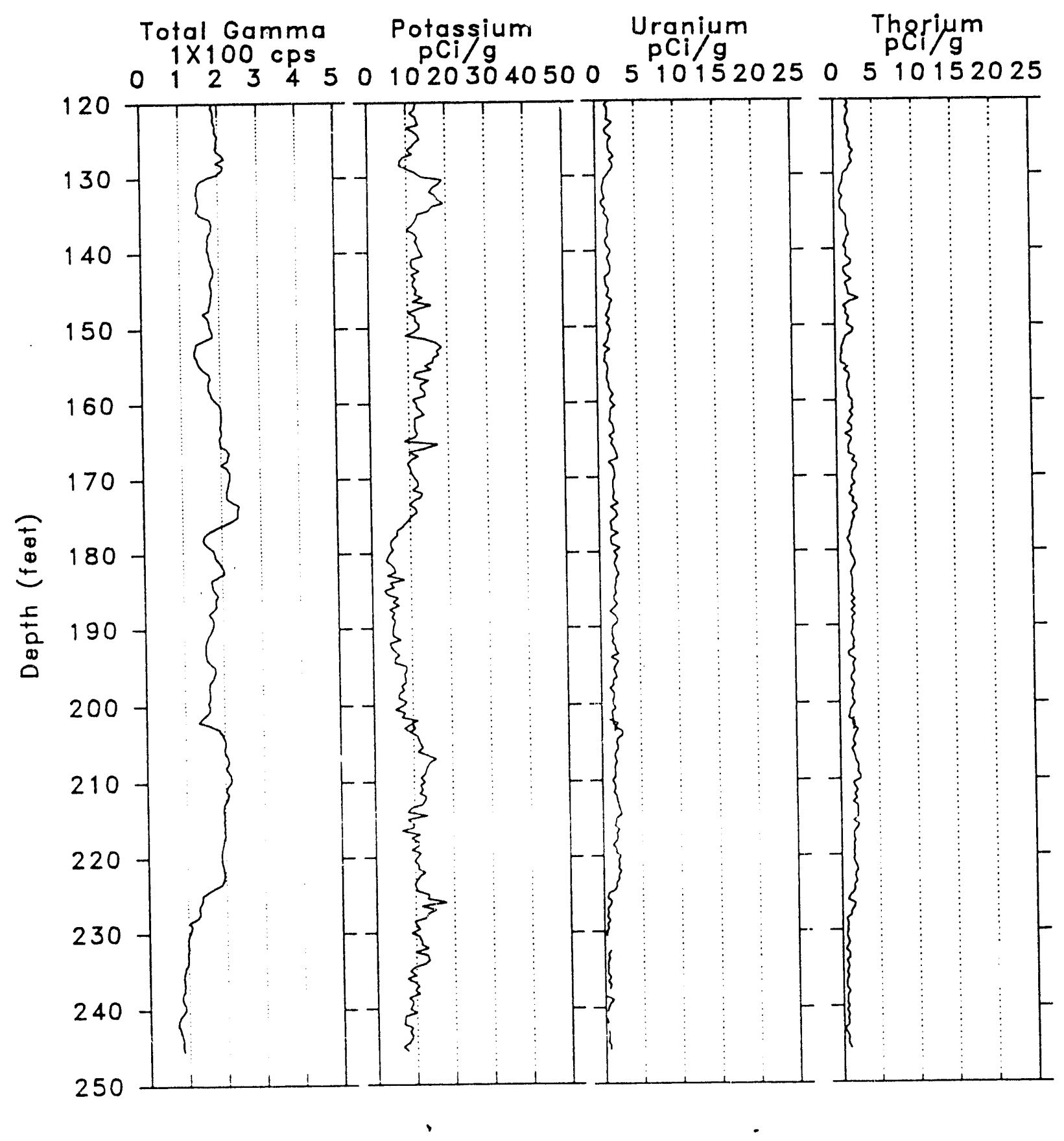


RLS Spectral Gamma-Ray Borehole Survey

Project: U 17 Crib

Borehole: 299-W19-26
Log Date : Mar 17, 1993

Anal Date: Apr 08, 1993

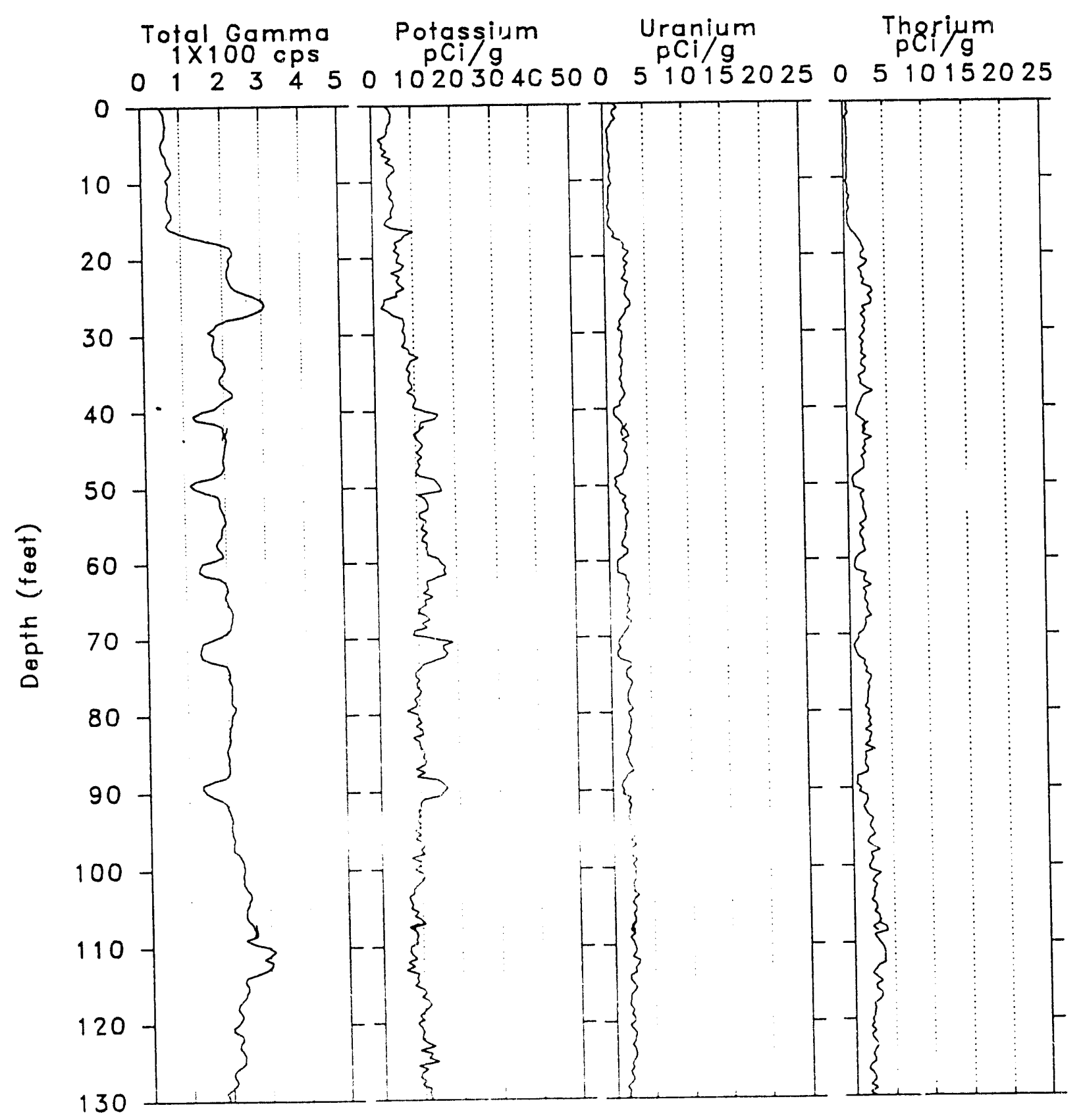


RLS Spectral Gamma-Ray Borehole Survey

Project: $\cup 17$ Crib

Borehole : 299-W19-26
Log Date: Mar 17, 1993

Anal Date: Apr 08, 1993

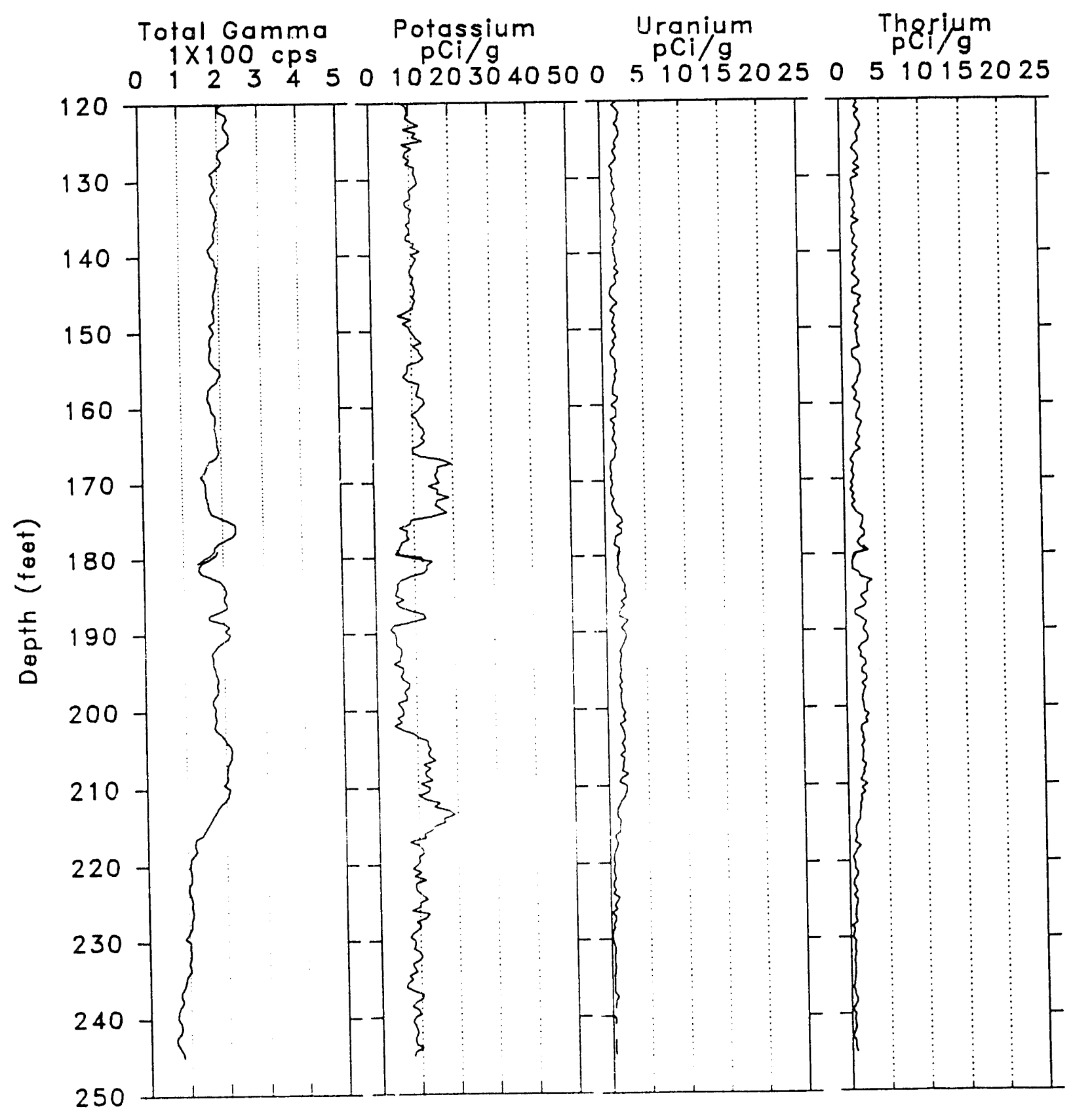


RLS Spectral Gamma-Ray Borehole Survey

Project: $U-17$ Crib Loggirig

Borehole : 299-W19-89
Log Date: Dec 30, 1992

Anal Date: Jan 12, 1993

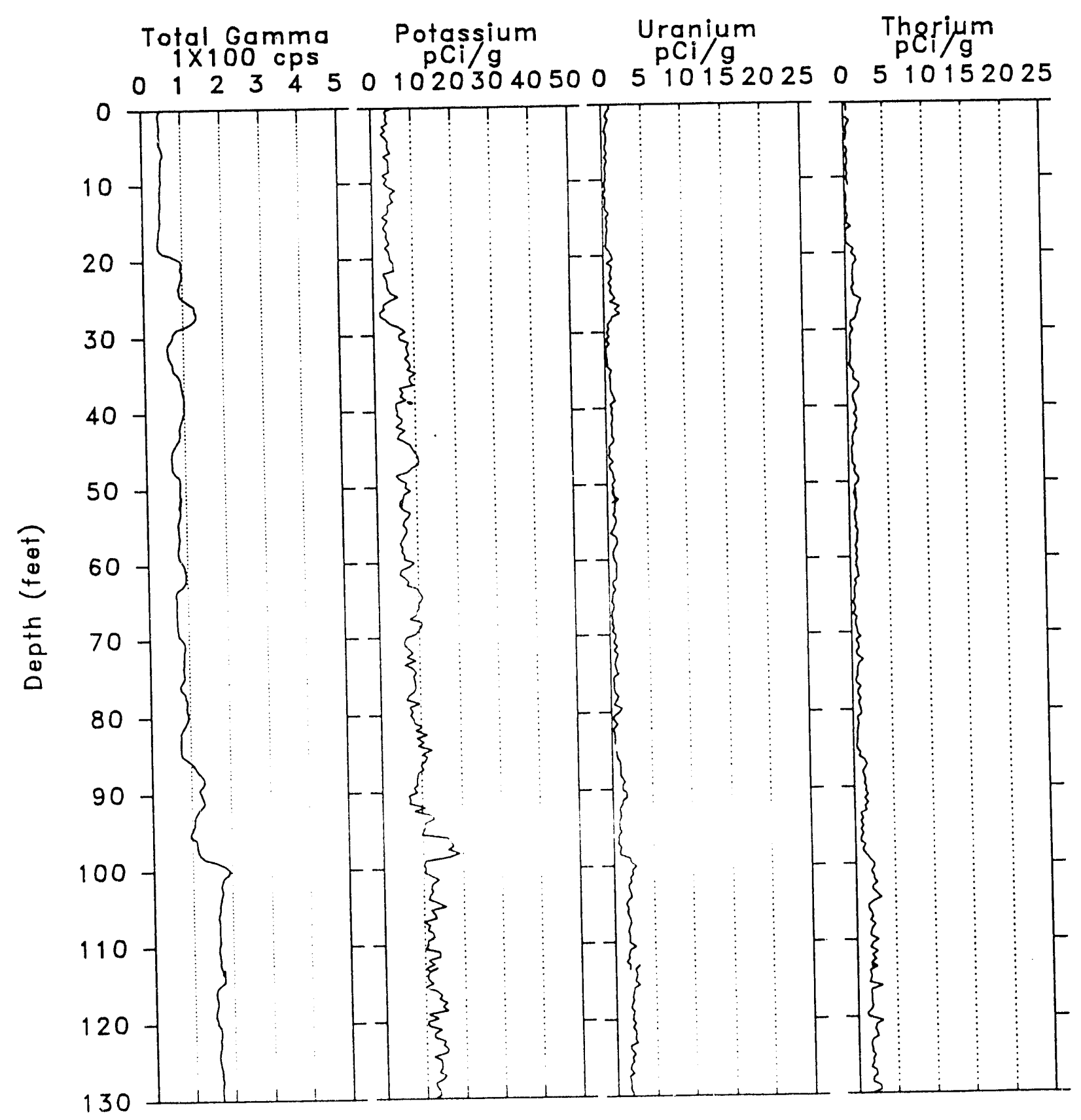


RLS Spectral Gamma-Ray Borehole Survey

Project: U? 17 Crib Logging

Borehole : 299-W19-89
Log Date : Dec 30, 1992

Anal Date: Jan 12, 1993

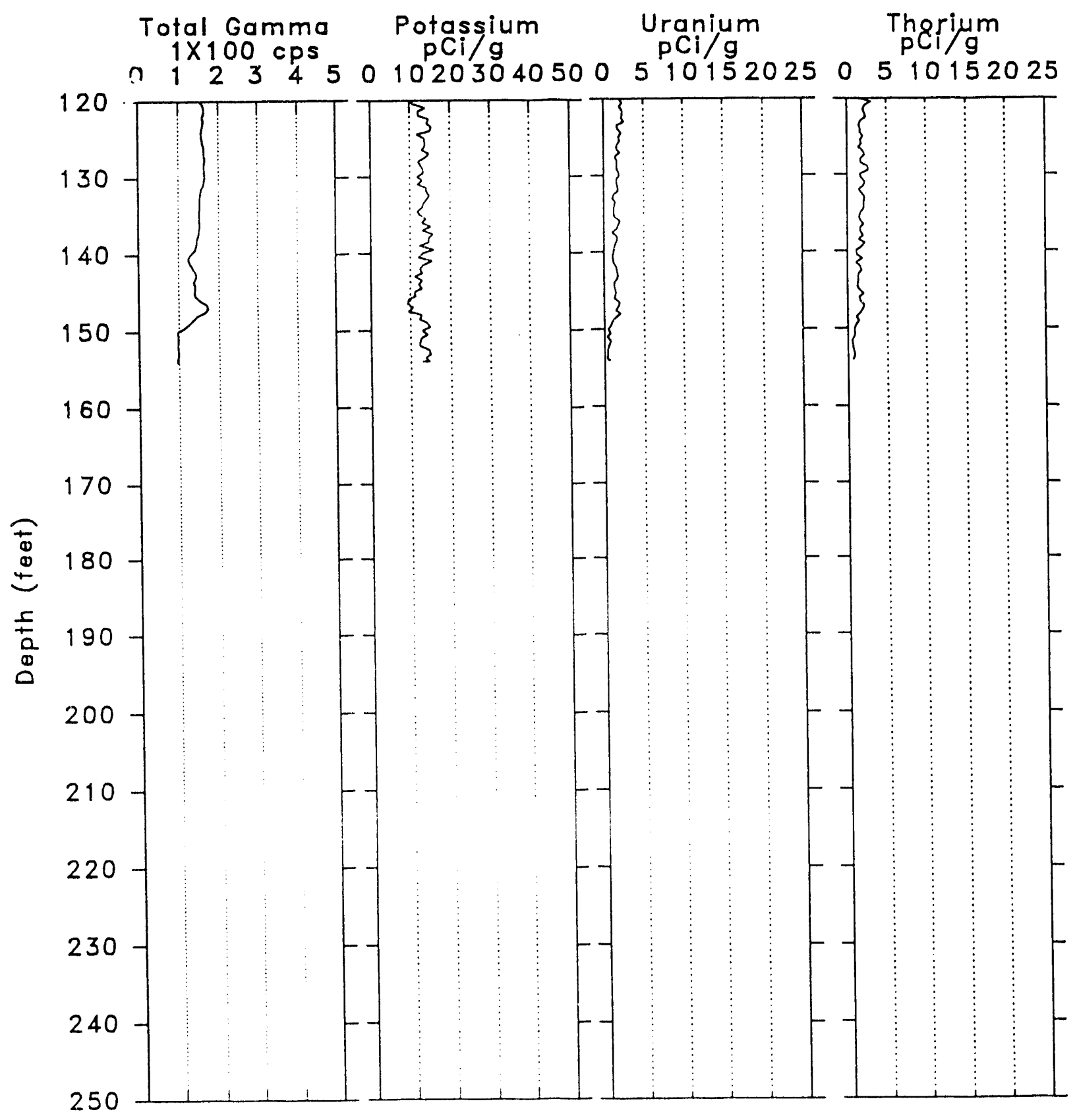


RLS Spectral Gamma-Ray Borehole Survey

Project: $\quad U-17$ Crib Logging

Borehole : 299-iv19-90
Log Date : Dec 22, 92

Anal Date: Jan 13, 93

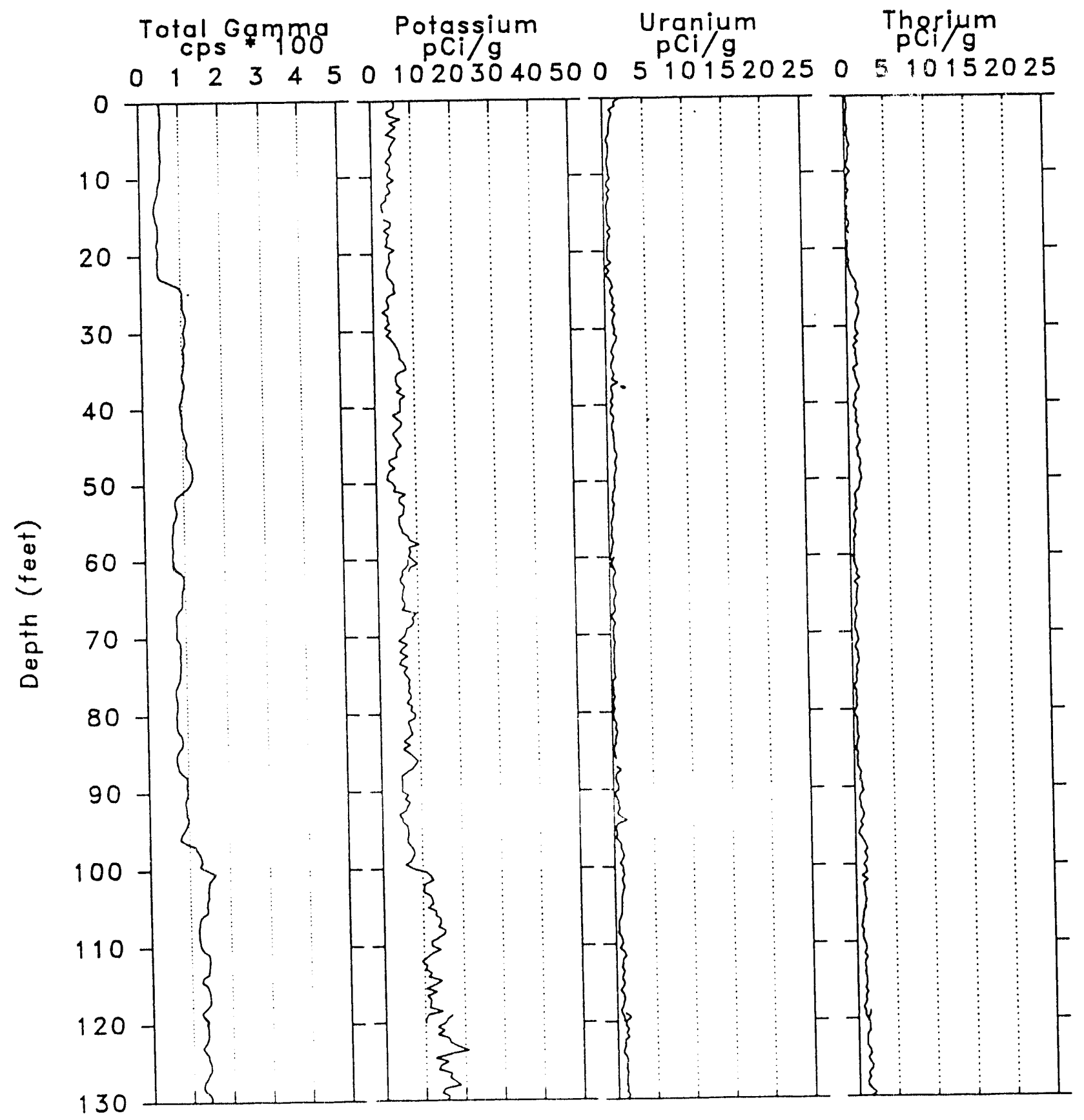


RLS Spectral Gamma-Ray Borehole Survey

Project: $\quad U-17$ Crib Logging

Borehole: 299-W19-90
Log Date : Dec 22, 92 Anal Date: Jan 13, 93

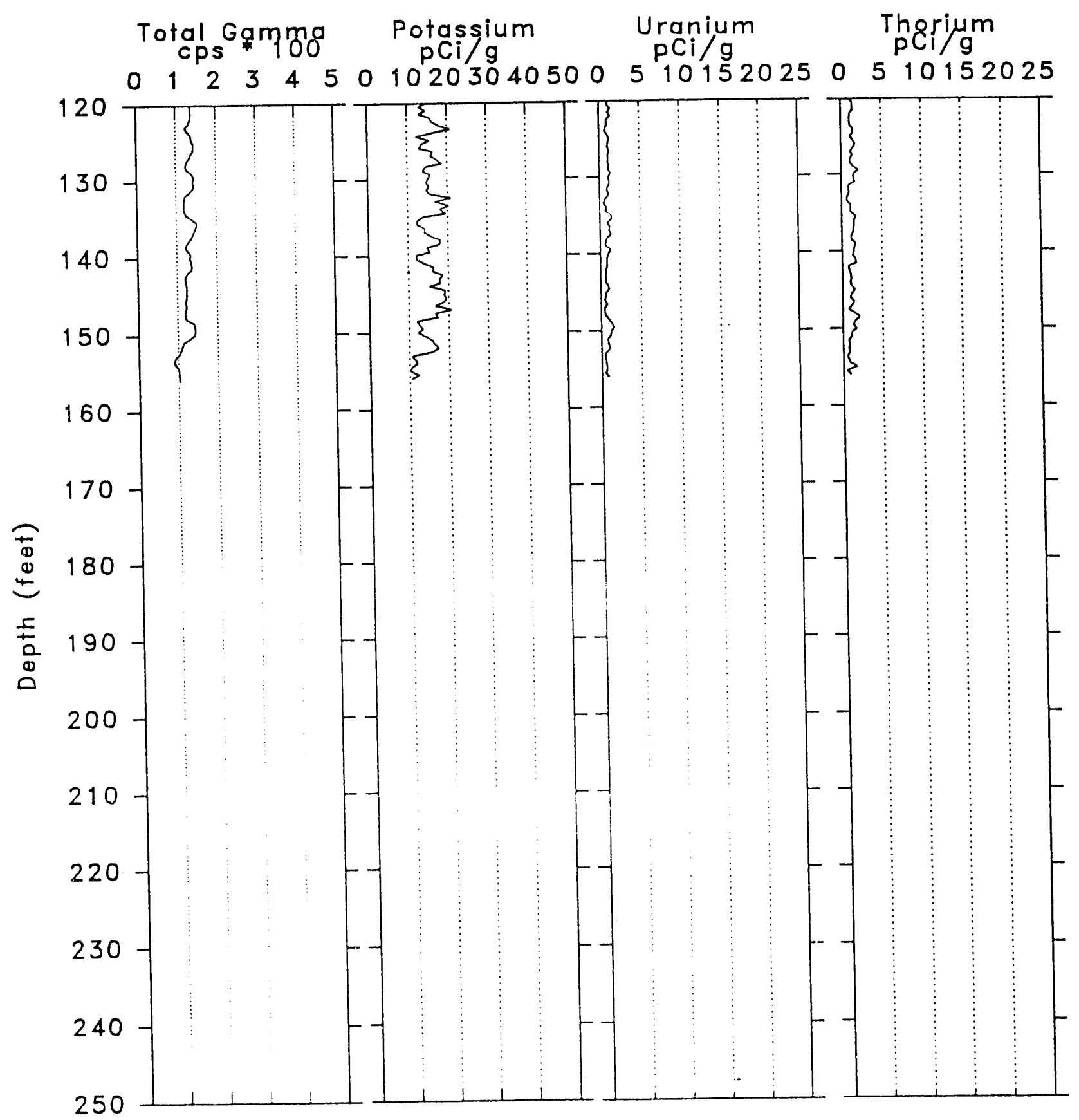




\section{DISTRIBUTION}

Number of copies

OFFSITE

1

Southwest Research Institute

6220 Culebra Road

San Antonio, Texas 78284

B. Sagar

ONSITE

8

U.S. Department of Energy, Richland Operations Office

M. J. Furman

R3-80

J. E. Mecca

R3-81

R. S. 011 ero

R3-81

J. E. Rasmussen

A5-15

R. K. Stewart

A5-19

D. W. Templeton

R3-81

S. H. Wisness

A5-15

RL Public Reading Room

Al-65

1

Pacific Northwest Laboratory

PNL Technical Files

$\mathrm{K} 1-11$

Westinghouse Hanford Company

L. L. Adams

T7-20

E. S. Ahl strom

HO-36

L. E. Borneman

J. W. Cammann

J. E. Cottre11

B. A. Davis

D. G. Farwick

K. R. Fecht

R. T. Hirano

M. P. Johansen

B2-35

H4-14

T7-20

R3-82

H4-16

H6-06

R. E. Johnson

B5-25

A5- 19

V. G. Johnson

T1-30

D. E. Kelley

R. Khaleel

N. W. Kline

H6-06

R3-46

HO-.36

A. J. Knepp

HO-36

A. G. Law

H6-06

S. T. Noga

H6-06

R. K. Price

S6-19

J. J. Ratcliffe

H6-06

J. A. Rawl ins

B5-25

HO-36

Distr-1 


\section{DISTRIBUTION (cont.)}

Number of copies

ONSITE

Westinghouse Hanford Company

$\begin{array}{ll}\text { S. P. Reidel } & \mathrm{H} 6-06 \\ \text { B. Sawyer } & \mathrm{H} 0-33 \\ \text { J. C. Sonnichsen } & \mathrm{H} 4-14 \\ \text { D. R. Speer } & \mathrm{R} 1-48 \\ \text { D. K. Tyler } & \mathrm{H6}-06 \\ \begin{array}{l}\text { Central Files } \\ \text { Document Processing }\end{array} & \mathrm{L} 8-04 \\ \quad \text { and Distribution (2) } & \\ \begin{array}{l}\text { Information Release } \\ \quad \text { Administration }\end{array} & \mathrm{L} 8-15 \\ & \end{array}$



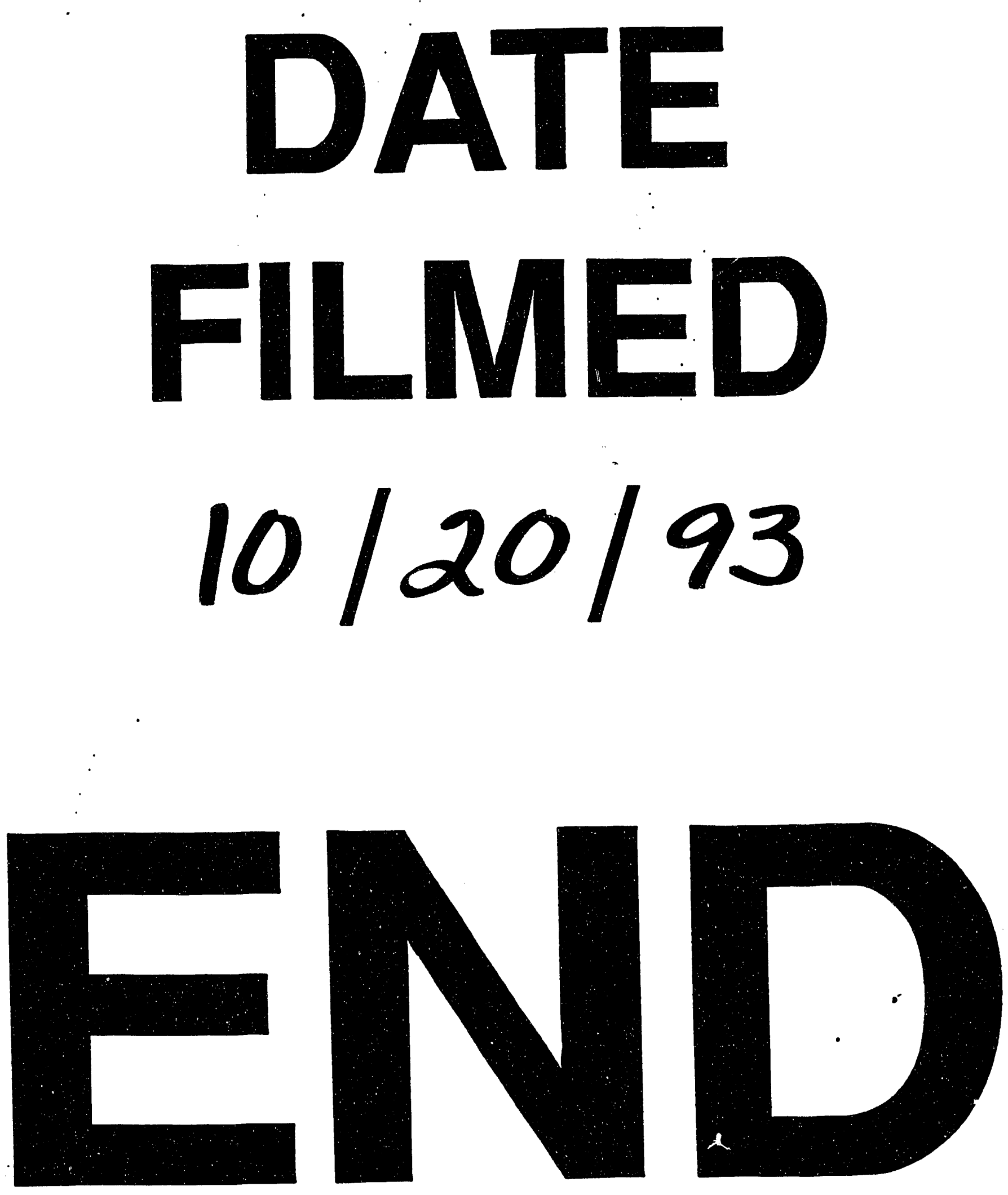
